LBNL-54770

\title{
Monitoring the Energy-Use Effects of Cool Roofs on California Commercial Buildings
}

\author{
Hashem Akbari, Ronnen Levinson, Steve Konopaki \\ and \\ Leo Rainer of the Davis Energy Group \\ Heat Island Group \\ Environmental Energy Technologies Division \\ Ernest Orlando Lawrence Berkeley National Laboratory \\ University of California \\ Berkeley, California 94720
}

July 2004

This work was supported by the California Energy Commission under Contract No. 400-00-039 and Contract No. 500-99-013, Work Authorization 20, Task 14, through the U.S. Department of Energy under Contract No. DEAC03-76SF00098. 


\section{DISCLAIMER}

This document was prepared as an account of work sponsored by the United States Government. While this document is believed to contain correct information, neither the United States Government nor any agency thereof, nor The Regents of the University of California, nor any of their employees, makes any warranty, express or implied, or assumes any legal responsibility for the accuracy, completeness, or usefulness of any information, apparatus, product, or process disclosed, or represents that its use would not infringe privately owned rights. Reference herein to any specific commercial product, process, or service by its trade name, trademark, manufacturer, or otherwise, does not necessarily constitute or imply its endorsement, recommendation, or favoring by the United States Government or any agency thereof, or The Regents of the University of California. The views and opinions of authors expressed herein do not necessarily state or reflect those of the United States Government or any agency thereof or The Regents of the University of California. 


\section{ACKNOWLEDGEMENTS}

This report was supported by the California Energy Commission's Public Interest Energy Research Program (PIER) under Contract No. 400-00-039 and later Contract No. 500-99-013, Work Authorization 20, Task 14; also by the Assistant Secretary for Renewable Energy under Contract No. DE-AC03-76SF00098.

The authors wish to thank the continued support and advice of Commissioner Dr. Arthur Rosenfeld and various individuals and managers at Commission, including Nancy Jenkins, Phil Spartz, Martha Brook, Virginia Lew, Ray Darby, and Melinda Rogers. We also wish to thank Dan Martens and Curt Morton of Kaprielian Brothers Packing Company; Tom Spoon of Carpeteria Flooring Center; Ricki Stricker of Building Inspection Professionals; Jim Poltl of San Marcos Unified School District; and Lucinda Shelbourne of Richland Elementary School for their cooperation in this monitoring project. 


\section{PREFACE}

The Public Interest Energy Research (PIER) Program supports public interest energy research and development that will help improve the quality of life in California by bringing environmentally safe, affordable, and reliable energy services and products to the marketplace.

The PIER Program, managed by the California Energy Commission (Energy Commission), annually awards up to $\$ 62$ million to conduct the most promising public interest energy research by partnering with Research, Development, and Demonstration (RD\&D) organizations, including individuals, businesses, utilities, and public or private research institutions.

PIER funding efforts are focused on the following six RD\&D program areas:

- Buildings End-Use Energy Efficiency

- Industrial/Agricultural/Water End-Use Energy Efficiency

- Renewable Energy

- Environmentally Preferred Advanced Generation

- Energy-Related Environmental Research

- Strategic Energy Research

What follows is the final report for Contract \#500-99-013, conducted by the Lawrence Berkeley National Laboratory. This report is entitled "Monitoring the Energy-Use Effects of Cools Roofs on California Commercial Buildings". This project contributes to the Buildings End-Use Energy Efficiency program.

For more information on the PIER Program, please visit the Energy Commission's Web site at: http://energy.ca.gov/research/index.html or contact the Energy Commission's Publications Unit at 916-654-5200. 


\section{ABSTRACT}

Solar-reflective roofs stay cooler in the sun than solar-absorptive roofs. Such "cool" roofs achieve lower surface temperatures that reduce heat conduction into the building and the building's cooling load.

The California Energy Commission has funded research in which Lawrence Berkeley National Laboratory (LBNL) has measured the electricity use and peak demand in commercial buildings to document savings from implementing the Commission's Cool Roofs program. The study seeks to determine the savings achieved by cool roofs by monitoring the energy use of a carefully selected assortment of buildings participating in the Cool Roofs program.

Measurements were needed because the peak savings resulting from the application of cool roofs on different types of buildings in the diverse California climate zones have not been well characterized to date. Only a few occupancy categories (e.g., office and retail buildings) have been monitored before this, and those were done under a limited number of climatic conditions. To help rectify this situation, LBNL was tasked to select the buildings to be monitored, measure roof performance before and after replacing a hot roof by a cool roof, and document both energy and peak demand savings resulting from installation of cool roofs.

We monitored the effects of cool roofs on energy use and environmental parameters in six California buildings at three different sites: a retail store in Sacramento; an elementary school in San Marcos (near San Diego); and a 4-building cold storage facility in Reedley (near Fresno). The latter included a cold storage building, a conditioning and fruit-palletizing area, a conditioned packing area, and two unconditioned packing areas (counted as one building).

Results showed that installing a cool roof reduced the maximum roof surface temperature of each building by $60-75^{\circ} \mathrm{F}$.

- In the retail store building in Sacramento, applying a cool coating reduced the maximum roof surface temperature elevation by $60-65^{\circ} \mathrm{F}$, and reduced the underroof temperature in the conditioned area by as much as $40-50^{\circ} \mathrm{F}$. For the period of $08 / 08 / 2002$ to $09 / 30 / 2002$, the estimated savings in average air conditioning energy use was about $83 \mathrm{kWh} /$ day $\left(52 \% ; 6.7 \mathrm{Wh} / \mathrm{ft}^{2} /\right.$ day). On hot days when the afternoon temperature exceeded $100^{\circ} \mathrm{F}$, the measured savings in average peak demand for peak hours (hours 12-17) was about 12-13 kW (about $1 \mathrm{~W}$ per square foot of conditioned area).

- In the school building in San Marcos, the reductions in the maximum roof surface temperature and under-roof temperature were about the same as for the retail store. For the period of $07 / 08 / 2002$ to $08 / 20 / 2002$, the estimated savings in average air conditioning energy use was about $22-26 \mathrm{kWh} /$ day $\left(17-18 \%\right.$; 3.9-4.5 Wh/ $\mathrm{ft}^{2} /$ day). On hot days when the afternoon temperature exceeded $90^{\circ} \mathrm{F}$, the measured savings in average peak demand for hours $10-16$ were about $3.1 \mathrm{~kW}$ (about $0.5 \mathrm{~W}$ per square foot of conditioned area).

- In the cold storage facility in Reedley, coating reduced the maximum roof surface temperature elevation by $65-75^{\circ} \mathrm{F}$. The under-roof and inside temperatures closely followed each other at $32-35^{\circ}$ F. For the period of $07 / 11 / 2002$ to $09 / 14 / 2002$, and 
$07 / 11 / 2002$ to $08 / 18 / 2003$, the estimated savings in average chiller energy use was about $360-500 \mathrm{kWh} /$ day $\left(3-4 \%\right.$; 5.3-7.5 Wh/ $\mathrm{ft}^{2} /$ day). On hot days when the afternoon temperature exceeded $100^{\circ} \mathrm{F}$, the measured savings in average peak demand for peak hours (hours 12-18) was about 32-40 kW (about 0.5-0.6 W per square foot of conditioned area).

The measured savings in all these buildings exceeded our initial estimates that were based on simulations of the buildings. Using the measured data and calibrated simulations, we estimated savings for similar buildings installing cool roofs in retrofit applications for all sixteen California climate zones.

- For similar retail stores in climate zones 2 and 4-16, installing a cool roof can save about 500-1400 kWh per year per $1000 \mathrm{ft}^{2}$ of conditioned roof area. Estimates of average peak demand savings for hours 12 to 17 for all 16 climate zones range from $0.27-0.54 \mathrm{~W} / \mathrm{ft}^{2}$.

- For similar school buildings in climate zones 2-16, installing a cool roof can save from $300-600 \mathrm{kWh}$ per year per $1000 \mathrm{ft}^{2}$ of conditioned roof area. Estimates of average peak demand savings for hours 12 to 17 for all 16 climate zones range from $0.24-0.35 \mathrm{~W} / \mathrm{ft}^{2}$.

- For similar cold storage buildings in all 16 climate zones, installing a cool roof can save about 400-700 kWh per year per $1000 \mathrm{ft}^{2}$ of conditioned roof area. Estimates of average peak demand savings for hours 12-17 for all 16 climate zones range from $0.36-0.61 \mathrm{~W} / \mathrm{ft}^{2}$. 


\section{TABLE OF CONTENTS}

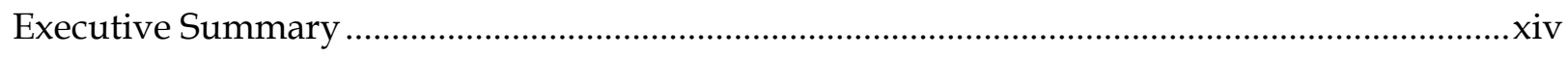

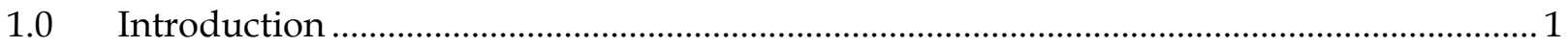

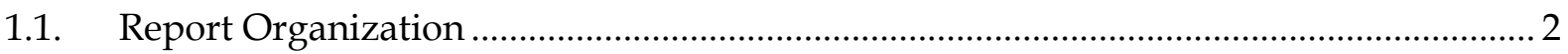

2.0 Energy Benefits and Environmental Impacts of Cool Roofs............................................ 3

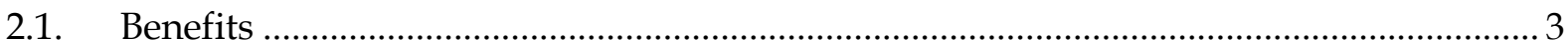

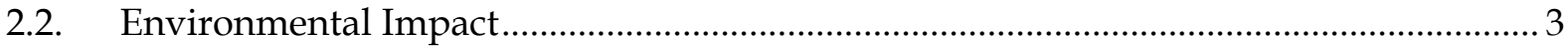

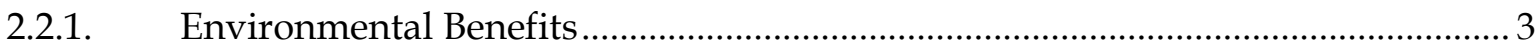

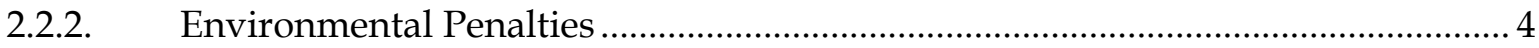

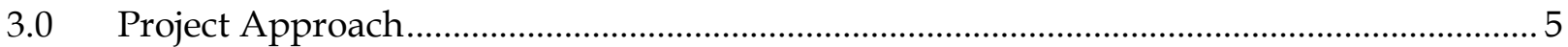

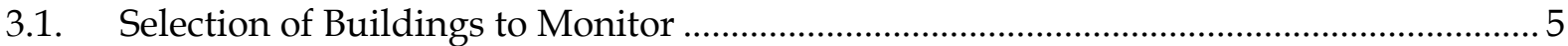

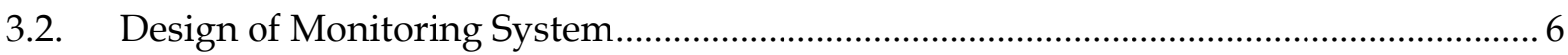

3.3. Monitoring System Specification, Procurement, Installation, Commissioning, and

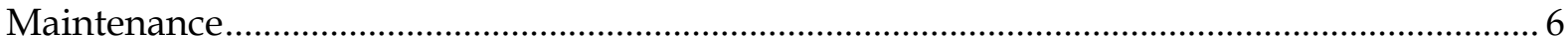

3.4. Base-Case Data Collection, Review, Analysis and Troubleshooting ............................. 9

3.5. Coordination During Cool Roof Installations .............................................................. 9

3.6. Cool Roof Data Collection, Review, Analysis and Troubleshooting .............................. 9

3.7. Estimation of Electricity and Peak Demand Savings ................................................... 9

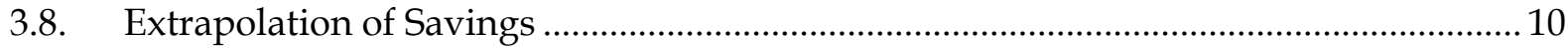

3.8.1. Analysis Plan for Extrapolation of Savings...................................................... 10

4.0 Methodology for Estimating Cooling Energy and Power Savings ................................... 11

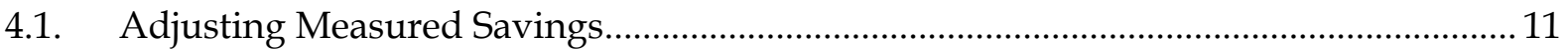

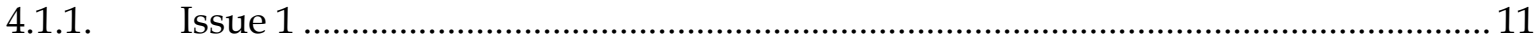

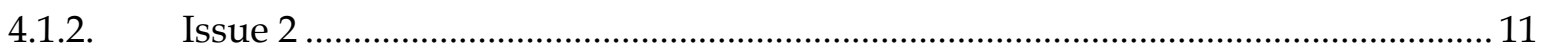

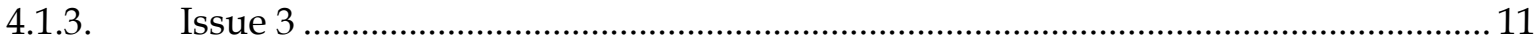

4.2. Simulating Savings in Various California Climate Zones ........................................... 13

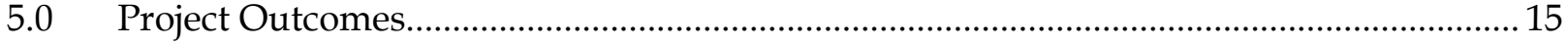

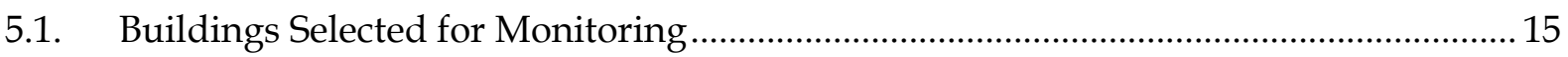

5.1.1. Establishing Project Goals and Selection Criteria................................................ 15

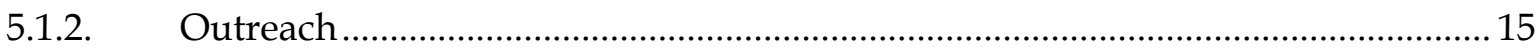




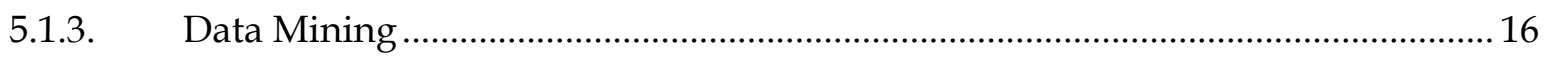

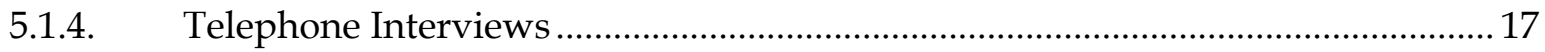

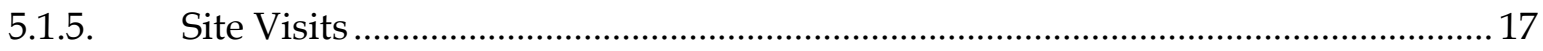

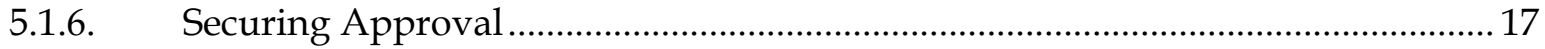

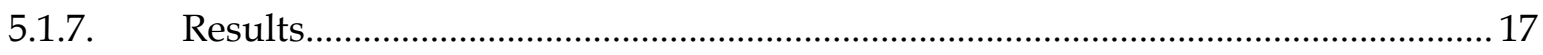

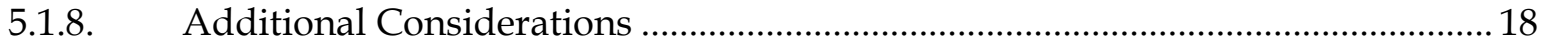

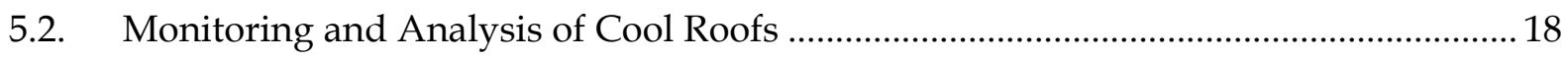

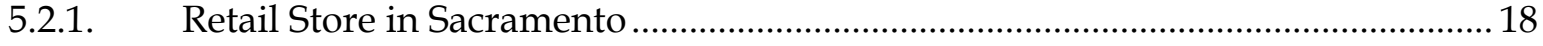

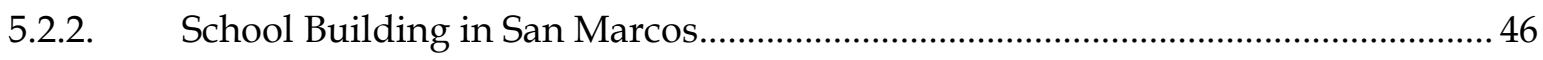

5.2.3. Fruit Packing/Cold Storage Facility in Reedley ................................................... 80

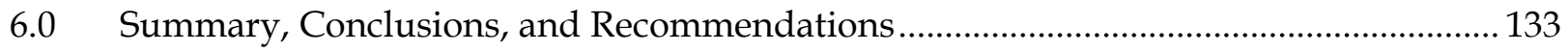

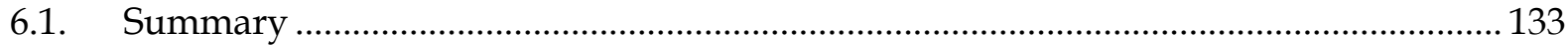

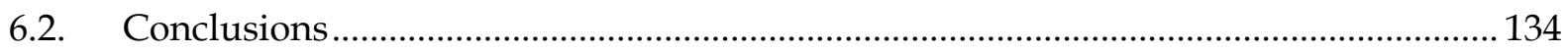

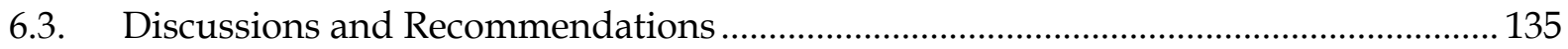

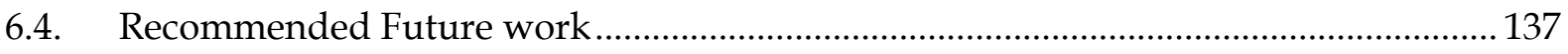

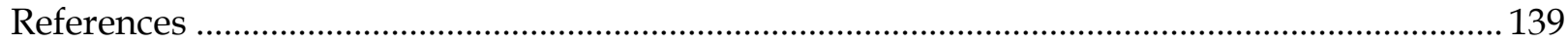

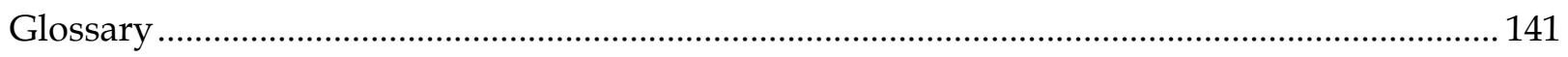

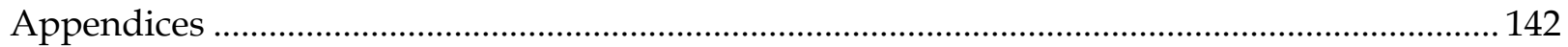

Appendix A. Building Recruitment Letter ........................................................................... 143

Appendix B. Methodology to Extrapolate Savings from Application of Cool Roofs................ 145

Appendix C. Extension of the Cool Roof Retrofit Deadline for 10 Buildings .......................... 147 


\section{LIST OF FIGURES}

Figure 1. Locations of the 16 California Climate Zones. .......................................................... 14

Figure 2. Carpeteria Flooring Center in Sacramento: Exterior.

Figure 3. Carpeteria Flooring Center in Sacramento: (a) showroom, dropped ceiling; (b) showroom, open ceiling; (c) warehouse; (d) office; (e) roof before coating; and (f) roof after coating.

Figure 4. Carpeteria Flooring Center in Sacramento: Building floor plan.................................. 23

Figure 5. Carpeteria Flooring Center in Sacramento: Temperature sensors on (a) roof surface, (b) roof underside, and (c) insulation underside...................................................................... 26

Figure 6. Carpeteria Flooring Center in Sacramento: Indoor air temperature sensor. ................ 27

Figure 7. Carpeteria Flooring Center in Sacramento: Weather tower........................................ 27

Figure 8. Carpeteria Flooring Center in Sacramento: Metered panels (a) panel A/C and panel A,

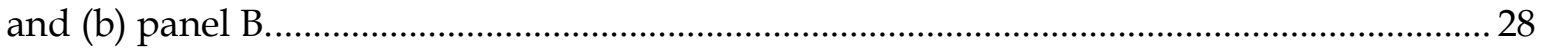

Figure 9. Carpeteria Flooring Center in Sacramento: Hourly temperatures for two-week periods before and after installation of a reflective roof coating on September 11, 2002................. 30

Figure 10. Carpeteria Flooring Center in Sacramento: Average hourly temperatures before (Pre) and after (Post) installation of reflective roof coating........................................................... 31

Figure 11. Carpeteria Flooring Center in Sacramento: Hourly and daily air conditioning energy uses.

Figure 12. Carpeteria Flooring Center in Sacramento: Daily electricity uses for weekdays during Pre and Post periods for AC1 and AC2 as a function of daily outdoor and indoor temperature difference $\left(\Delta \mathrm{T}=\mathrm{T}_{\text {out }}-\mathrm{T}_{\text {in }}\right)$..

Figure 13. Carpeteria Flooring Center in Sacramento: Hourly electrical demand during Pre and

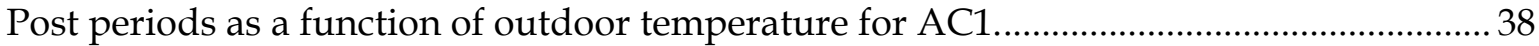

Figure 14. Richland Elementary School in San Marcos: (a) building \#2 NE elevation; (b) building \#2 SW elevation; (c) classroom 2-05; and (d) library....

Figure 15. Richland Elementary School in San Marcos: Building monitoring point locations... 49

Figure 16. Richland Elementary School in San Marcos: (a) old mineral cap sheet, and (b) new roof membrane. 51

Figure 17. Richland Elementary School in San Marcos: Data logger location. 54

Figure 18. Richland Elementary School in San Marcos: Temperature sensors (a) roof surface, (b) roof underside, (c) plenum air, and (d) room air 55

Figure 19. Richland Elementary School in San Marcos: Weather tower. 56

Figure 20. Richland Elementary School in San Marcos: Metering panels: (a) panel 2A, and (b) panel 2B. 
Figure 21. Richland Elementary School in San Marcos: Hourly temperatures for two-week periods before and after installation of the white roof membrane on July 28, 2002.

Figure 22. Richland Elementary School in San Marcos: Average hourly temperatures before (Pre) and after (Post) installation of the white roof membrane.

Figure 23. Richland Elementary School in San Marcos: Average hourly temperatures for three weeks before (Pre) and three weeks after (Post) installation of the reflective roof. .

Figure 24. Richland Elementary School in San Marcos: Hourly and daily air conditioning energy uses.

Figure 25. Richland Elementary School in San Marcos: Daily electricity use. Note the significant change in total energy use between the Pre and Post periods..

Figure 26. Richland Elementary School in San Marcos: Daily electricity uses for weekdays during Pre and Post periods for AC1, AC2, and AC3 as a function of daily outdoor and indoor temperature difference $\left(\Delta \mathrm{T}=\mathrm{T}_{\text {out }}-\mathrm{T}_{\text {in }}\right)$..

Figure 27. Richland elementary school in San Marcos: Daily electricity use for weekdays during Pre0, Pre1, and Post periods for AC1 as a function of daily outdoor and indoor temperature difference $\left(\Delta \mathrm{T}=\mathrm{T}_{\text {out }}-\mathrm{T}_{\text {in }}\right)$......

Figure 28. Richland Elementary School in San Marcos: Daily electricity use for weekdays for $\mathrm{AC} 1, \mathrm{AC} 2$, and $\mathrm{AC} 3$ as a function of daily outdoor and indoor temperature difference $(\Delta \mathrm{T}=$ $\mathrm{T}_{\text {out }}-\mathrm{T}_{\mathrm{in}}$ ), for 3 weeks before (Pre) and after (Post) installing cool roof..

Figure 29. Richland Elementary School in San Marcos: Correlations between total airconditioning daily electricity use and AC1 daily electricity use..

Figure 30. Richland Elementary School in San Marcos: Electrical demand as a function of outdoor temperature $\left(\mathrm{T}_{\text {out }}\right)$ for 3 weeks before and after installation of the cool roof........ 71

Figure 31. Kaprielian Brothers Packing Company (Cold Storage) Facility in Reedley: Building monitoring point locations.

Figure 32. Kaprielian Brothers Packing Company (Cold Storage) Facility in Reedley: (a) cold storage building; (b) packing building; (c) cold storage building roof; (d) packing building roof; (e) cold storage room \#4; and (f) packing room \#1.

Figure 33. Kaprielian Brothers Packing Company (Cold Storage) Facility in Reedley: (a) coated cold storage roof, and (b) coated packing roof.

Figure 34. Kaprielian Brothers Packing Company (Cold Storage) Facility in Reedley: Data logger box.

Figure 35. Kaprielian Brothers Packing Company (Cold Storage) Facility in Reedley: (a) EPDM surface temperature sensor, (b) galvalum surface temperature sensor, (c) heat flux sensor, and $(d)$ interior air temperature sensor.

Figure 36. Kaprielian Brothers Packing Company (Cold Storage) Facility in Reedley: Weather tower 
Figure 37. Kaprielian Brothers Packing Company (Cold Storage) Facility in Reedley: Metering panels (a) T2 panel current transducer installation, and (b) A/C panel current transducer installation

Figure 38. Kaprielian Brothers Packing Company (Cold Storage) Facility in Reedley: Hourly temperatures and conducted heat flux through the roof for two-week periods before and three weeks after installation of a reflective roof coating on August 19, 2002.

Figure 39. Kaprielian Brothers Packing Company (Cold Storage) Facility in Reedley: Average hourly temperatures and insolation before (Pre) and after (Post) installation of reflective roof coating..

Figure 40. Kaprielian Brothers Packing Company (Cold Storage) facility in Reedley: Average hourly conducted heat flux through the roof before (Pre) and after (Post) installation of reflective roof coating..

Figure 41. Kaprielian Brothers Packing Company (Cold Storage) Facility in Reedley: Hourly temperatures for two weeks before and three weeks after installation of reflective roof coating on August 19, 2002.

Figure 42. Kaprielian Brothers Packing Company (Cold Storage) Facility in Reedley: Average hourly temperatures before (Pre) and after (Post) installation of reflective roof coating.... 96

Figure 43. Kaprielian Brothers Packing Company (Cold Storage) Facility in Reedley: Hourly temperatures and conducted heat flux through the roof for two weeks before and three weeks after installation of reflective roof coating on August 19, 2002.

Figure 44. Kaprielian Brothers Packing Company (Cold Storage) Facility in Reedley: Average hourly temperatures before (Pre) and after (Post) installation of reflective roof coating.... 98

Figure 45. Kaprielian Brothers Packing Company (Cold Storage) Facility in Reedley: Hourly temperatures for two weeks before and three weeks after installation of reflective roof coating on August 19, 2002. ' $\mathrm{G}$ ' and ' $\mathrm{H}$ ' are measurements at two locations on the roof..100

Figure 46. Kaprielian Brothers Packing Company (Cold Storage) Facility in Reedley: Average hourly temperatures before (Pre) and after (Post) installation of reflective roof coating.. 101

Figure 47. Kaprielian Brothers Packing Company (Cold Storage) Facility in Reedley: Average hourly outdoor temperatures and insolation for periods of 1-, 2-, and 3-weeks before (Pre) and after (Post) installation of reflective roof coating.....

Figure 48. Kaprielian Brothers Packing Company (Cold Storage) Facility in Reedley: Average hourly inside temperatures for periods of 1-, 2-, and 3-weeks before (Pre) and after (Post) installation of reflective roof coating.....

Figure 49. Kaprielian Brothers Packing Company (Cold Storage) Facility in Reedley: Hourly and daily air conditioning energy uses, and roof heat flux.

Figure 50. Kaprielian Brothers Packing Company (Cold Storage) Facility in Reedley: Daily production of packed fruits from June 19 to September 7, 2002..

Figure 51. Kaprielian Brothers Packing Company (Cold Storage) Facility in Reedley: Daily electricity use for weekdays for chiller (T1) and air conditioning (AC) for packing area 
during Pre and Post periods as a function of daily outdoor and indoor temperature difference $\left(\Delta \mathrm{T}=\mathrm{T}_{\text {out }}-\mathrm{T}_{\text {in }}\right)$

Figure 52. Kaprielian Brothers Packing Company (Cold Storage) Facility in Reedley: Average hourly outdoor temperature and insolation for the period of July 11 through August 18 of 2002 (Pre) and 2003 (Post)

Figure 53. Kaprielian Brothers Packing Company (Cold Storage) Facility in Reedley: Daily electricity use for chiller and AC for packing for 2002 Pre-period, 2002 Post-period, and 2003 Post-period.

Figure 54. Kaprielian Brothers Packing Company (Cold Storage) Facility in Reedley: Electrical demand as a function of outdoor temperature for the chiller (WT1).

Figure 55. Kaprielian Brothers Packing Company (Cold Storage) Facility in Reedley: Electrical demand as a function of outdoor temperature for packing area AC.

Figure 56. Kaprielian Brothers Packing Company (Cold Storage) Facility in Reedley: Chiller electrical demand for 2002 Pre-period and 2003 Post-period.

Figure 57. Kaprielian Brothers Packing Company (Cold Storage) facility in Reedley: Packing area A/C electrical demand for 2002 Pre-period and 2003 Post-period 


\section{LIST OF TABLES}

Table 1. Initial goals for building selection, shown by type and location.................................. 7

Table 2. Typical measurement points and instrumentation....................................................... 8

Table 3. Carpeteria Flooring Center in Sacramento: Building monitoring points....................... 22

Table 4. Carpeteria Flooring Center in Sacramento: Roof albedo measurements. ...................... 24

Table 5. Carpeteria Flooring Center in Sacramento: Building HVAC units............................... 25

Table 6. Carpeteria Flooring Center in Sacramento: Regression of air conditioner daily

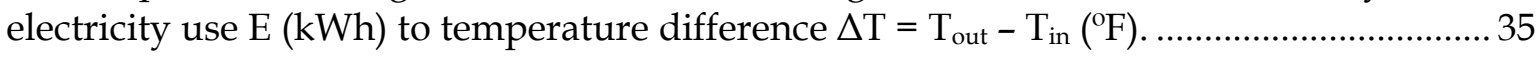

Table 7. Carpeteria Flooring Center in Sacramento: Estimates of daily A/C electricity savings.35

Table 8. Carpeteria Flooring Center in Sacramento: Regression of AC1 air conditioner power demand $\mathrm{P}(\mathrm{kW})$ to outside air temperature $\mathrm{T}_{\text {out }}\left({ }^{\circ} \mathrm{F}\right)$ via relation $\mathrm{P}=\mathrm{a}+\mathrm{bT}$......................36

Table 9. Carpeteria Flooring Center in Sacramento: Building description.

Table 10. Carpeteria Flooring Center in Sacramento: Simulated cooling electricity savings and adjustment factors. ${ }^{a}$

Table 11. Carpeteria Flooring Center in Sacramento: Estimated annual energy savings of buildings with similar characteristics in other California Climate Zones.

Table 12. Carpeteria Flooring Center in Sacramento: Estimated peak demand savings of buildings with similar characteristics in other California Climate Zones.

Table 13. Richland Elementary School in San Marcos: Building monitoring points.................. 48

Table 14. Richland Elementary School in San Marcos: Roof albedo measurements. .................. 50

Table 15. Richland Elementary School in San Marcos: HVAC specifications. 53

Table 16. Richland Elementary School in San Marcos: School track schedule during summer 2002.

Table 17. Richland Elementary School in San Marcos: Regression of air conditioner daily electricity use $\mathrm{E}(\mathrm{kWh})$ to temperature difference $\Delta \mathrm{T}=\mathrm{T}_{\text {out }}-\mathrm{T}_{\text {in }}\left({ }^{\circ} \mathrm{F}\right)$.

Table 18. Richland Elementary School in San Marcos: Estimates of daily A/C electricity savings.

Table 19. Richland Elementary School in San Marcos: Regression of total building power demand $\mathrm{P}(\mathrm{kW})$ to outside air temperature $\mathrm{T}_{\text {out }}\left({ }^{\circ} \mathrm{F}\right)$ via relation $\mathrm{P}=\mathrm{a}+\mathrm{bT}$.

Table 20. Richland Elementary School in San Marcos: Building description. 72

Table 21. Richland Elementary School in San Marcos: Measured and simulated cooling electricity savings and adjustment factors. ${ }^{a}$. .76 
Table 22. Richland Elementary School in San Marcos: Estimated annual energy savings of buildings with similar characteristics in other California Climate Zones.

Table 23. Richland Elementary School in San Marcos: Estimated peak demand savings of buildings with similar characteristics in other California Climate Zones.

Table 24. Kaprielian Brothers Packing Company (Cold Storage) Facility in Reedley: Building characteristics.

Table 25. Kaprielian Brothers Packing Company (Cold Storage) Facility in Reedley: Building monitoring points 83

Table 26. Kaprielian Brothers Packing Company (Cold Storage) Facility in Reedley: Roof albedo measurements.

Table 27. Kaprielian Brothers Packing Company (Cold Storage) Facility in Reedley: Regression of air conditioner daily electricity use $\mathrm{E}(\mathrm{kWh})$ to temperature difference $\Delta \mathrm{T}=\mathrm{T}_{\text {out }}-\mathrm{T}_{\text {in }}\left({ }^{\circ} \mathrm{F}\right)$

Table 28. Kaprielian Brothers Packing Company (Cold Storage) Facility in Reedley: Estimates of average daily A/C electricity savings..... 110

Table 29. Kaprielian Brothers Packing Company (Cold Storage) Facility in Reedley: Estimates of average daily A/C electricity savings based on average electricity use for a 21-day, a 14day, and a 7-day period before and after installing cool roof..

Table 30. Kaprielian Brothers Packing Company (Cold Storage) Facility in Reedley: Chiller power demand and savings.

Table 31. Kaprielian Brothers Packing Company (Cold Storage) Facility in Reedley: Packing area $\mathrm{AC}$ average power demand and savings.

Table 32. Kaprielian Brothers Packing Company (Cold Storage) Facility in Reedley: Chiller average power demand and savings.

Table 33. Kaprielian Brothers Packing Company (Cold Storage) facility in Reedley: Building description.

Table 34. Kaprielian Brothers Packing Company (Cold Storage) facility in Reedley: Average monthly chillers cooling electricity and peak-demand savings.

Table 35. Average daily insolation $\left(\mathrm{Wh} / \mathrm{ft}^{2}\right)$ data for all California climate zones.

Table 36. Extrapolation of energy savings for cold storages in other climate regions in California.

Table 37. Extrapolation of peak-demand savings for cold storages in other climate regions in California.

Table 38. Estimated annual energy savings and peak demand reduction in July. 


\section{EXECUTIVE SUMMARY}

In August 2000, California AB970 was passed to help reduce the state's peak electric demand by $300 \mathrm{MW}$ by summer of 2001 through the execution of several peak-demand reduction measures, including cool roofs.1 The California Energy Commission (Energy Commission), tasked to implement AB970, allocated \$10 M to the Cool Roofs Program, primarily targeting commercial buildings. The Energy Commission hoped the Program would stimulate the installation of 100 million $\mathrm{ft}^{2}$ of cool roofs by the end of summer 2001; at an estimated peak-demand reduction of $0.3 \mathrm{~W} / \mathrm{ft}^{2}$, peak-demand savings for the Program would thus total about $30 \mathrm{MW}$.

The PIER Buildings area funded Lawrence Berkeley National Laboratory (LBNL) to monitor actual performance of a carefully selected assortment of California buildings, so savings realized from implementing the Cool Roofs Program can be documented. Monitoring of buildings was necessary because peak savings from cool roof retrofits have not been well quantified: only limited building types (e.g., office and retail) have been monitored to date, and those under limited climate conditions. To determine the Program's effect, peak savings data for cool roof applications on different building types in the diverse California climate zones is needed.

The project approach included selecting buildings for monitoring, designing and installing the monitoring systems for the selected buildings, collecting base-case (pre-retrofit) data, coordination during the cool roof installations, collecting cool roof (post-retrofit) data, estimating electricity and peak demand savings, and extrapolating savings to other California climate zones.

About 250 candidate buildings to monitor were identified initially; the number was then reduced to about a dozen by telephone interviews. These buildings then each were appraised by a half-day site visit, during which an engineer surveyed the building, reviewed past utility bills, took photographs and then prepared a brief evaluation report for LBNL. Six buildings ultimately completed the pre- and post-retrofit monitoring sequence: a retail store in Sacramento, an elementary school in San Marcos (near San Diego), and four buildings at a fruit packing facility in Reedley (near Fresno) - a cold storage building, a conditioning and fruitpalletizing area, a conditioned packing area, and two unconditioned packing areas. An office building in Irvine was also monitored prior to re-roofing with cool materials, but the retrofit never occurred.

Monitoring protocols were developed for each site and data acquisition systems installed to collect information every fifteen minutes. Typical data collected included roof surface temperature, roof underside temperature, indoor and plenum air temperatures, heat flux through the roof, outdoor weather conditions, incoming solar radiation, cooling electricity use, and total electricity use.

$1 \mathrm{~A}$ "cool" roof reflects most of the incoming solar radiation, so the roof surface stays at a temperature lower than that of a roof that absorbs the radiation. Lower roof surface temperatures reduce heat conduction into buildings and hence decrease cooling loads. 
The parameters affecting building air-conditioning (A/C) load include outside temperature, inside temperature, solar heat gain, internal loads, relative humidity, and wind speed.

Sensitivity analysis of A/C electricity use to these environmental parameters was performed for the initial conditions ("Pre" period) and for conditions after the roof was coated ("Post" period). This permitted normalizing the Pre and Post conditions for all parameters before estimating savings derived from the application of white roof coating.

\section{Description of Monitored Buildings}

Building characteristics are summarized in Table ES-1.

Retail Store. Carpeteria Flooring Center, located in Sacramento, is a 15,000 $\mathrm{ft}^{2}$ single story concrete tilt-up building, with an interior area consisting of sales floor $\left(9,000 \mathrm{ft}^{2}\right)$, office $(1,500$ $\left.\mathrm{ft}^{2}\right)$ and warehouse $\left(4,500 \mathrm{ft}^{2}\right)$. The roof, a plywood deck covered with gray mineral cap sheet, was installed in 1989 and the measured surface reflectance prior to retrofitting was $21 \%$. Roof reflectance increased to over $80 \%$ after covering the roof with a white elastomeric coating. Preretrofit data was taken for 32 days (08/08/2002 to 09/09/2002); the post-retrofit data collection period was 20 days long (09/11/2002 to 09/30/2002).

Elementary School. Building \#2 of Richland Elementary School, located in San Marcos (near San Diego) is a 6,200 $\mathrm{ft}^{2}$, single-story wood frame permanent classroom structure that includes three classrooms (each $\left.960 \mathrm{ft}^{2}\right)$, a computer laboratory $\left(960 \mathrm{ft}^{2}\right)$, a restroom area $\left(380 \mathrm{ft}^{2}\right)$ and a library $\left(1,920 \mathrm{ft}^{2}\right)$. The roof was covered with a gray mineral capsheet and insulated with 8 " fiberglass batt attached to the underside of the roof sheathing; measured reflectance was 0.25. Initial reflectance following the installation of a white PVC single-ply membrane roof was 0.79 ; this dropped to about 0.65 in two months. Pre-retrofit data was taken for 65 days (05/24/2002 to $07 / 28 / 2002)$; post-retrofit data was collected in two periods totaling 190 days $(61+129$; $07 / 31 / 2002$ to $09 / 30 / 2002$ and $05 / 24 / 2003$ to $09 / 30 / 2003$ ). The second set of post-retrofit data was collected to clarify our analysis.

Fruit Packing/ Cold Storage Facility. Kaprielian Brothers Packing Company, an industrial cold storage complex located near Fresno, has approximately 100,000 ft' $\mathrm{of}^{2}$ high-bay warehouse buildings. The complex consists of cold storage, packing and conditioning rooms that process, pack and store stone fruit, such as peaches. Most of the cold storage area was roofed with a black membrane (reflectance of about $4 \%$ ), while the packing and conditioning areas were roofed with bare metal (reflectance of about 30\%). All roofs were coated with a white elastomer (initial reflectance of about 63-70\%). Pre-retrofit data was taken for 51 days (06/28/2002 to $08 / 18 / 2002)$. The total post-retrofit data collection period was divided into two segments totaling 190 days $(38+152 ; 08 / 23 / 2002$ to 09/30/2002 and 05/01/2003 to 09/30/2003). The second set of post-retrofit data was collected to confirm savings at this site with a highly variable operation schedule. 


\section{Results}

Energy savings are summarized in Table ES-1.

Retail Store Building in Sacramento. The average outdoor hourly temperatures for the preand post-retrofit periods (denoted "Pre" and "Post," respectively) were remarkably similar. The maximum surface temperature was reduced by $60-65^{\circ} \mathrm{F}$ after coating the roof. Radiative cooling to a clear sky can bring the minimum nighttime roof surface temperature for the Pre and Post periods to about $20^{\circ} \mathrm{F}$ below the ambient air temperature. The under-roof temperature in one conditioned area of the store with a plenum (area ' $\mathrm{A}$ ') was reduced about $40-50^{\circ} \mathrm{F}$ by retrofitting with a cool roof. The under-roof temperature in conditioned area ' $\mathrm{B}$ ' and unconditioned area ' $\mathrm{C}$ ' (areas without a plenum) was about $15-20^{\circ} \mathrm{F}$ higher in the Pre period than in the Post period.

To normalize for the variations of outdoor ambient conditions during the Pre and Post periods, we performed a statistical analysis of A/C electricity use versus (a) difference between outside and inside temperatures $\left(\Delta \mathrm{T}=\mathrm{T}_{\text {out }}-\mathrm{T}_{\text {in }}\right)$, and $(\mathrm{b})$ daily total insolation. The results showed significant correlation of the A/C electricity use with temperature difference, but the regressions against insolation were not statistically significant and did not improve the overall regression models. (The daily insolation did not vary greatly over the pre- and post-retrofit periods). Without correcting for weather conditions of the Pre and Post periods, the savings in the total average daily air conditioning $(\mathrm{AC} 1+\mathrm{AC} 2)$ electricity use for the building are estimated at $81 \mathrm{kWh} /$ day (51\%). After correcting for the changes in the weather during Pre and Post period, the estimated savings were still in excess of 50\%! Daily A/C electric savings were also seen to rise with increasing outdoor temperature. For the period of 08/08/2002 to 09/30/2002, the estimated savings in average air conditioning energy use was about $83 \mathrm{kWh} /$ day $(52 \% ; 6.7$ $\mathrm{Wh} / \mathrm{ft}^{2} /$ day).

To estimate the effect of cool roofs on peak demand electricity use, we inspected hourly data for $\mathrm{AC} 1$ (the larger of the two units) during hours 12 through 17. The results depicted a substantial reduction in hourly $\mathrm{A} / \mathrm{C}$ electricity use for all hours, with peak demand reductions higher for higher outdoor temperature. On very hot days when the outside temperature is $105^{\circ} \mathrm{F}$, the total peak demand savings for AC1+AC2 is estimated at $14.3 \mathrm{~kW}(51 \%)$. On typical hot days when the afternoon temperature exceeded $100^{\circ} \mathrm{F}$, the measured savings in average peak demand for peak hours (hours 12-17) was about 12-13 kW (about $1 \mathrm{~W} / \mathrm{ft}^{2}$ of conditioned area).

School Building in San Marcos. The average outdoor hourly temperatures for the Post period were about $4-5^{\circ} \mathrm{F}$ higher than those of the Pre period. The maximum surface temperature was reduced by about $65^{\circ} \mathrm{F}$ after re-roofing. Radiative cooling to the sky can bring the minimum nighttime surface temperature for the Pre and Post periods about $10-15^{\circ} \mathrm{F}$ below the ambient air temperature. The under-roof temperature was about $40-50^{\circ} \mathrm{F}$ higher in the Pre period than in the Post period.

The effect of the cool roof retrofit on A/C electric use at the school was less clear than at the retail store. Inspection of the daily air conditioning electricity use data revealed high fluctuations in daily consumption, mainly due to irregular classroom operation. The building is cooled with three A/C systems: AC1, AC2, and AC3. Statistical analysis of AC1 electricity use versus the temperature difference and daily total insolation was again performed, with significant correlation between A/C electricity use and temperature difference observed; regressions against insolation were not statistically significant. Data for the Post period indicated a very close correlation between the total $\mathrm{A} / \mathrm{C}$ use $\left(\mathrm{AC}_{\text {tot }}=\mathrm{AC} 1+\mathrm{AC} 2+\mathrm{AC} 3\right)$ and the 
AC1 electricity use. For the period of $07 / 08 / 2002$ to $08 / 20 / 2002$, the estimated savings in average air conditioning energy use was about $22-26 \mathrm{kWh} /$ day $\left(17-18 \%\right.$; 3.9-4.5 Wh/ $\mathrm{ft}^{2} /$ day).

To estimate the effect of cool roofs on peak demand electricity use, we inspected the hourly total building demand for hours 10 through 17, for the Pre and Post periods. Data clearly showed a visible reduction in hourly A/C demand for all hours but hours 10 and 14 (the correlations for these hours were poor). Peak demand reductions appear to be higher for higher outdoor temperature. The average peak demand reduction for hours $10-16$ is about $3.1 \mathrm{~kW}(11 \%)$ when the outside temperature is $90^{\circ} \mathrm{F}$ (about $0.5 \mathrm{~W} / \mathrm{ft}^{2}$ of conditioned area; $2.8 \mathrm{~kW}$ for $80^{\circ} \mathrm{F}$ ).

Fruit Packing/Cold Storage Facility in Reedley (Four Buildings). The average outdoor hourly temperatures for the Post period were about the same as the Pre period. The maximum surface temperatures at these buildings were reduced by $65-75^{\circ} \mathrm{F}$ after re-roofing. At night, roof surface temperatures cooled down to $20-25^{\circ} \mathrm{F}$ below outdoor temperature, primarily because of radiation exchange to nighttime clear sky. Hourly conduction heat flux during a 24-hour period in the cold storage area ranged from -6 to $11 \mathrm{~W} / \mathrm{ft}^{2}$ for the Pre period and ranged from -1.4 to $4.2 \mathrm{~W} / \mathrm{ft}^{2}$ for the Post period, a drop of about $6 \mathrm{~W} / \mathrm{ft}^{2}$ during peak daytime insolation.

We performed statistical analyses of chiller electricity use versus (a) difference between outside and inside temperatures $\left(\Delta \mathrm{T}=\mathrm{T}_{\text {out }}-\mathrm{T}_{\text {in }}\right)$, and (b) daily total insolation. The results showed very weak correlations of electricity use with temperature difference. The regressions against insolation were even weaker and were not statistically significant.

Analysis of the hourly data show significant reduction in the chillers' power demand during the evening and nighttime hours (when there is no sun!). We learned from the facility engineer that in late summer 2002, the suction pressure of the chiller compressors was raised from 32 psia to 35 psia. An increase in the suction pressure (while the discharge pressure is kept constant) can significantly improve the performance of the chiller systems. After the installation of the cool roofs, the operators discovered that the building load can be met with higher evaporator temperatures. As a result, they had increased the suction pressure, resulting in a significant reduction in chillers' energy use that was not directly related to installation of cool roofs.

To estimate the effect of cool roofs on peak demand electricity use, we subtracted these nighttime biases from the difference of the Pre- and Post-period chiller power demand for all hours. This resulted in average peak demand chiller savings (for hours 12-18) of 32-40 kW (6$7 \%$ ), or about $0.5-0.6 \mathrm{~W} / \mathrm{ft}^{2}$. This approach also yielded a daily energy savings of $440-500 \mathrm{kWh}$ (3-4\%), or about 6.6-7.5 Wh/ $\mathrm{ft}^{2}$. Although the percent savings in the fruit packing/cold storage facility is smaller than the other two buildings, the absolute energy savings is about the same as the retail store and higher than that of the school building.

The analysis of the hourly data for the packing area A/C system did not show any savings.

Estimate of Energy and Peak Demand Savings in 16 California Climates Zones. Using the measured data and calibrated simulations, we estimated savings for similar buildings installing cool roofs in retrofit applications for all 16 California climate zones (or CZ; see Table ES-2).

- For comparable retail stores in climate zones 2 and 4-16, installing a cool roof can save about 500-1400 kWh per year per $1000 \mathrm{ft}^{2}$ of conditioned roof area. Estimates of average peak demand savings for hours 12 to 17 for all 16 climate zones range from $0.27-0.54 \mathrm{~W} / \mathrm{ft}^{2}$. Assuming an average cost of $\$ 0.10 / \mathrm{kWh}$, in a retrofit application in 
all climate zones (but Zone 1 and 3), the estimates of energy savings range from 0.05 $0.14 \$ / \mathrm{ft}^{2}\left(0.5-1.4 \$ / \mathrm{m}^{2}\right)$. Assuming a monthly peak-demand charge of $\$ 20 / \mathrm{kW}$, the estimated May-October peak-demand savings is 0.03-0.06 \$/ $\mathrm{ft}^{2}\left(0.32-0.64 \$ / \mathrm{m}^{2}\right)$. The total annual savings (energy plus peak demand reduction) ranges from 0.08 to 0.20 $\$ / \mathrm{ft}^{2}\left(0.8\right.$ to $\left.2.0 \$ / \mathrm{m}^{2}\right)$.

- For comparable school buildings in climate zones 2-16, installing a cool roof can save from $300-600 \mathrm{kWh}$ per year per $1000 \mathrm{ft}^{2}$ of conditioned roof area. Estimates of average peak demand savings for hours 12 to 17 for all 16 climate zones range from $0.20-0.33 \mathrm{~W} / \mathrm{ft}^{2}$. Assuming an average cost of $\$ 0.10 / \mathrm{kWh}$, in climate zones 2-16, the estimates of energy savings range from $0.03-0.06 \$ / \mathrm{ft}^{2}\left(0.3-0.6 \$ / \mathrm{m}^{2}\right)$. Assuming a monthly peak-demand charge of $\$ 20 / \mathrm{kW}$, the estimated May-October peak-demand savings is $0.024-0.04 \$ / \mathrm{ft}^{2}\left(0.26-0.42 \$ / \mathrm{m}^{2}\right)$. The total annual savings (energy and peak demand reduction) ranges from 0.06 to $0.10 \$ / \mathrm{ft}^{2}\left(0.6\right.$ to $\left.1.0 \$ / \mathrm{m}^{2}\right)$.

- For comparable cold storage buildings in all 16 climate zones, installing a cool roof can save from $400-700 \mathrm{kWh}$ per year per $1000 \mathrm{ft}^{2}$ of conditioned roof area. Estimates of average peak demand savings for hours 12-17 for all 16 climate zones range from $0.36-0.61 \mathrm{~W} / \mathrm{ft}^{2}$. The chillers' energy savings estimates for mid-May to midSeptember high-season summer period ranges from 0.4 to $0.7 \mathrm{kWh} / \mathrm{ft}^{2}$ (4.2 to 6.9 $\left.\mathrm{kWh} / \mathrm{m}^{2}\right)$. Assuming an average cost of $\$ 0.10 / \mathrm{kWh}$, the estimates of energy savings ranges from $0.04-0.07 \$ / \mathrm{ft}^{2}\left(\$ 0.4 / \mathrm{m}^{2}\right.$ to $\left.\$ 0.7 / \mathrm{m}^{2}\right)$. Assuming a monthly peak-demand charge of $\$ 20 / \mathrm{kW}$, the estimated mid-May to mid-September peak-demand savings is $0.026-0.043 \$ / \mathrm{ft}^{2}\left(0.28-0.46 \$ / \mathrm{m}^{2}\right)$. The total 4-month savings for this packing season ranges from 0.07 to $0.11 \$ / \mathrm{ft}^{2}\left(0.7\right.$ to $\left.1.1 \$ / \mathrm{m}^{2}\right)$. 
Table ES-1. Summary of building characteristics and savings.

\begin{tabular}{|c|c|c|c|c|c|}
\hline \multirow[t]{2}{*}{$\begin{array}{l}\text { Building } \\
\text { Characteristics }\end{array}$} & \multirow[t]{2}{*}{ Retail Store } & \multirow[t]{2}{*}{$\begin{array}{l}\text { Elementary } \\
\text { School }\end{array}$} & \multicolumn{3}{|c|}{$\begin{array}{l}\text { Fruit Packing/Cold Storage } \\
\text { Facility }\end{array}$} \\
\hline & & & $\begin{array}{l}\text { Cold } \\
\text { Storage }\end{array}$ & $\begin{array}{l}\text { Fruit } \\
\text { Cond- } \\
\text { itioning }\end{array}$ & $\begin{array}{l}\text { Fruit } \\
\text { Packing }\end{array}$ \\
\hline Location (CA) & Sacramento & San Marcos & \multicolumn{3}{|l|}{ Reedley } \\
\hline Number of stories & 1 & 1 & 1 & 1 & 1 \\
\hline Gross floor area $\left(\mathrm{ft}^{2}\right)$ & 17,300 & 6,140 & 52,800 & 13,800 & 36,200 \\
\hline $\begin{array}{l}\text { Conditioned floor area } \\
\left(\mathrm{ft}^{2}\right)\end{array}$ & 12,400 & 5,740 & 44,500 & 13,800 & 23,700 \\
\hline Roof construction & $\begin{array}{l}\text { Build-up } \\
\text { w/mineral } \\
\text { capsheet, } \\
\text { multi-year } \\
\text { radiant barrier }\end{array}$ & $\begin{array}{l}\text { Build-up } \\
\text { w/mineral } \\
\text { capsheet, plenum }\end{array}$ & $\begin{array}{l}\text { Black } \\
\text { EPDM }\end{array}$ & $\begin{array}{l}\text { Standing- } \\
\text { seam } \\
\text { metal }\end{array}$ & $\begin{array}{l}\text { Standing- } \\
\text { seam } \\
\text { metal }\end{array}$ \\
\hline Roof retrofit & $\begin{array}{l}\text { White } \\
\text { coating }\end{array}$ & $\begin{array}{l}\text { White PVC } \\
\text { single-ply } \\
\text { membrane }\end{array}$ & $\begin{array}{l}\text { White } \\
\text { coating }\end{array}$ & $\begin{array}{l}\text { White } \\
\text { coating }\end{array}$ & $\begin{array}{l}\text { White } \\
\text { coating }\end{array}$ \\
\hline Roof/attic insulation & $\begin{array}{l}\text { Multi-layer } \\
\text { radiant barrier } \\
\text { (R-7 } \\
\text { equivalent) }\end{array}$ & $\begin{array}{l}\text { R-30 fiberglass } \\
\text { batt }\end{array}$ & $\begin{array}{l}\text { R-29 foam } \\
\text { (some } \\
\text { area R-12) }\end{array}$ & $\begin{array}{l}\mathrm{R}-25 \\
\text { foam }\end{array}$ & $\begin{array}{l}\text { R-8 } \\
\text { fiberglass } \\
\text { batt }\end{array}$ \\
\hline Roof solar reflectance & & & & & \\
\hline Pre-retrofit & 0.20 & 0.25 & 0.04 & 0.30 & 0.30 \\
\hline Post-retrofit & 0.80 & $0.65-0.79$ & $0.65-0.69$ & $0.63-0.70$ & $0.63-0.70$ \\
\hline Cooling equipment & $\begin{array}{l}\text { Packaged } \\
\text { single zone AC }\end{array}$ & $\begin{array}{l}\text { Packaged single } \\
\text { zone heat pump }\end{array}$ & $\begin{array}{l}\text { Central } \\
\text { ammonia } \\
\text { chillers }\end{array}$ & $\begin{array}{l}\text { Central } \\
\text { ammonia } \\
\text { chillers }\end{array}$ & $\begin{array}{l}\text { Packaged } \\
\text { single } \\
\text { zone AC }\end{array}$ \\
\hline Distribution & $\begin{array}{l}\text { Constant } \\
\text { volume forced } \\
\text { air with } \\
\text { economizer }\end{array}$ & $\begin{array}{l}\text { Constant volume } \\
\text { forced air with } \\
\text { economizer }\end{array}$ & $\begin{array}{l}\text { Two-pipe } \\
\text { fan coil }\end{array}$ & $\begin{array}{l}\text { Two-pipe } \\
\text { fan coil }\end{array}$ & No ducts \\
\hline
\end{tabular}




\begin{tabular}{|c|c|c|c|c|c|}
\hline \multirow{2}{*}{$\begin{array}{l}\text { Building } \\
\text { Characteristics }\end{array}$} & \multirow[t]{2}{*}{ Retail Store } & \multirow{2}{*}{$\begin{array}{l}\text { Elementary } \\
\text { School }\end{array}$} & \multicolumn{3}{|c|}{ Fruit Packing Facilities } \\
\hline & & & $\begin{array}{l}\text { Cold } \\
\text { Storage }\end{array}$ & $\begin{array}{l}\text { Fruit } \\
\text { Cond- } \\
\text { itioning }\end{array}$ & $\begin{array}{l}\text { Fruit } \\
\text { Packing }\end{array}$ \\
\hline \multicolumn{6}{|l|}{ Monitoring period } \\
\hline Pre-retrofit & $\begin{array}{c}8 \text { Aug - } 9 \text { Sep } \\
2002\end{array}$ & $\begin{array}{c}24 \text { May - } 28 \text { Jul, } \\
2002\end{array}$ & \multicolumn{3}{|c|}{28 Jun - 18 Aug, 2002} \\
\hline Post-retrofit & Sep 11-30, 2002 & $\begin{array}{c}31 \text { Jul - } 30 \text { Sep, } \\
\text { 2002; } 25 \text { May - } 30 \\
\text { Sep, } 2003\end{array}$ & \multicolumn{3}{|c|}{$\begin{array}{c}23 \text { Aug - } 30 \text { Sep, } 2002 \\
1 \text { Jun - } 30 \text { Sep, } 2003\end{array}$} \\
\hline $\begin{array}{l}\text { Monitored daily } \\
\text { average cooling } \\
\text { energy savings } \\
\text { Wh/day/ } \mathrm{ft}^{2} \text { of } \\
\text { conditioned floor area }\end{array}$ & $6.5(50 \%)$ & $4.2(17 \%)$ & $6.4(4 \%)$ & $6.4(4 \%)$ & $\begin{array}{l}\text { None } \\
\text { (open to } \\
\text { outdoors) }\end{array}$ \\
\hline $\begin{array}{l}\text { Monitored average } \\
\text { peak demand savings } \\
\mathrm{W} / \mathrm{ft}^{2} \text { of conditioned } \\
\text { floor area }\end{array}$ & $1.0(50 \%)$ & $0.5(12 \%)$ & $0.5(6 \%)$ & $0.5(6 \%)$ & $\begin{array}{l}\text { None } \\
\text { (open to } \\
\text { outdoors) }\end{array}$ \\
\hline
\end{tabular}


Table ES 2. Estimated annual energy savings and peak demand reduction in July.

\begin{tabular}{|c|c|c|c|c|c|c|}
\hline \multirow{2}{*}{$\begin{array}{l}\text { Climate } \\
\text { Zone }\end{array}$} & \multicolumn{2}{|c|}{ Retail Store $^{a}$} & \multicolumn{2}{|c|}{ School Buildingb } & \multicolumn{2}{|c|}{ Cold Storage Facilityc } \\
\hline & $\mathrm{kWh} / \mathrm{ft}^{2}$ & $\mathrm{~W} / \mathrm{ft}^{2}$ & $\mathrm{kWh} / \mathrm{ft}^{2}$ & $\mathrm{~W} / \mathrm{ft}^{2}$ & $\mathrm{kWh} / \mathrm{ft}^{2}$ & $\mathrm{~W} / \mathrm{ft}^{2}$ \\
\hline CZ01 & 0.06 & 0.06 & 0.10 & 0.24 & 0.42 & 0.36 \\
\hline CZ02 & 1.07 & 0.46 & 0.39 & 0.36 & 0.56 & 0.50 \\
\hline CZ03 & 0.37 & 0.27 & 0.34 & 0.30 & 0.55 & 0.47 \\
\hline CZ04 & 0.98 & 0.43 & 0.47 & 0.33 & 0.59 & 0.51 \\
\hline CZ05 & 0.55 & 0.32 & 0.28 & 0.30 & 0.55 & 0.48 \\
\hline CZ06 & 1.04 & 0.40 & 0.47 & 0.26 & 0.53 & 0.47 \\
\hline CZ07 & 0.92 & 0.33 & 0.48 & 0.25 & 0.49 & 0.44 \\
\hline CZ08 & 1.18 & 0.43 & 0.57 & 0.32 & 0.54 & 0.49 \\
\hline CZ09 & 1.10 & 0.40 & 0.50 & 0.31 & 0.51 & 0.49 \\
\hline CZ10 & 1.42 & 0.50 & 0.54 & 0.35 & 0.51 & 0.47 \\
\hline CZ11 & 1.00 & 0.45 & 0.42 & 0.33 & 0.67 & 0.61 \\
\hline CZ12 & 1.00 & 0.46 & 0.43 & 0.34 & 0.69 & 0.61 \\
\hline CZ13 & 1.29 & 0.54 & 0.49 & 0.35 & 0.69 & 0.61 \\
\hline CZ14 & 1.30 & 0.49 & 0.42 & 0.30 & 0.69 & 0.59 \\
\hline CZ15 & 1.52 & 0.51 & 0.60 & 0.32 & 0.58 & 0.45 \\
\hline CZ16 & 0.62 & 0.37 & 0.23 & 0.32 & 0.63 & 0.58 \\
\hline
\end{tabular}

\section{Notes:}

a. The estimates of annual energy savings for the Retail Store are for cooling energy savings and do not include potential heating penalties, since the building is heated with gas.

b. The School Building is cooled and heated with packaged heat pumps. The estimates of annual energy savings include summertime cooling-energy savings and wintertime heating-energy penalties.

c. The energy savings for the Cold Storage Facilities are for four months from mid-May to mid-September. The Cold Storage Facilities operate at a lower capacity for the reminder of the year. 


\subsection{Introduction}

In August 2000, California AB970 was passed to help reduce the state's peak electrical demand by 300 MW by summer of 2001 through the execution of several peak-demand reduction measures, including cool roofs.2 The California Energy Commission (Energy Commission), tasked to implement AB970, allocated \$10 M to the Cool Roofs Program, primarily targeting commercial buildings. The Energy Commission hoped the Program would stimulate the installation of 100 million $\mathrm{ft}^{2}$ of cool roofs by the end of summer 2001. At an estimated peakdemand reduction of $0.3 \mathrm{~W} / \mathrm{ft}^{2}$, peak-demand savings for the Program would thus total about $30 \mathrm{MW}$. The Energy Commission offered an average rebate of $\$ 0.10$ per square foot of installed cool roof (the rebate ranged from $\$ 0.05$ to $\$ 0.15$ per $\mathrm{ft}^{2}$, based on the existing roofing construction for a candidate building). The primary focus of the program was on commercial buildings, a market sector which already offers many cool roofing products.

Several field studies have documented measured energy savings that result from increasing roof solar reflectance.

- Akbari et al. (1997) reported monitored cooling-energy savings of $46 \%$ and peak power savings of $20 \%$ achieved by increasing the roof reflectance of two identical portable classrooms in Sacramento.

- Konopacki et al. (1998) documented measured savings of $12-18 \%$ in two commercial buildings in California.

- Parker et al. (1998) measured an average of 19\% energy savings in eleven Florida residences by applying reflective coatings on roofs.

- Parker et al. (1997) also monitored seven retail stores in a strip mall in Florida before and after applying a high-albedo coating to the roof and measured a $25 \%$ drop in seasonal cooling energy use.

- Hildebrandt et al. (1998) observed daily A/C savings of $17 \%, 26 \%$, and $39 \%$ in an office, a museum and a hospice, respectively, retrofitted high-albedo roofs in Sacramento.

- Akridge (1998) reported savings of $28 \%$ for a school building in Georgia which had an unpainted galvanized roof coated with white acrylic.

- Boutwell and Salinas (1986) showed an office building in southern Mississippi saved $22 \%$ after the application of a high-reflectance coating.

In addition to these field studies, computer simulations of cooling energy savings from an increased roof albedo have been documented in residential and commercial buildings in many studies, including Konopacki and Akbari (1998), Akbari et al. (1998); Parker et al. (1998); and Gartland et al. (1996). Konopacki et al. (1997) estimated the direct energy savings potential from high-albedo roofs in eleven U.S. metropolitan areas. The results showed that four major building types account for over $90 \%$ of the annual electricity and monetary savings: pre- 1980 residences $(55 \%)$, post-1980 residences $(15 \%)$, and office buildings and retail stores together

$2 \mathrm{~A}$ 'cool' roof reflects most of the incoming radiation, so the roof surface stays at a lower temperature than that of a roof that absorbs the radiation; lower roof surface temperatures lead to lower heat conduction into buildings and hence reduced cooling loads. 
(25\%). Furthermore, these four building types account for $93 \%$ of the total air-conditioned roof area. Regional savings were found to be a function of the following three factors: energy savings in the air-conditioned residential and commercial building stock; the percentage of buildings that were air-conditioned; and the aggregate regional roof area. Thus, populous cities with an older low-rise building stock, in hot and sunny climates, and with a high level of AC saturation provided the highest savings potential for heat island reduction measures. Metropolitan-wide annual savings were as much as \$37M for Phoenix and \$35M in Los Angeles and as low as \$3M in the heating-dominated climate of Philadelphia. Analysis of the scale of urban energy savings potential was further refined for five cities: Baton Rouge, LA; Chicago, IL, Houston, TX, Sacramento, CA; and Salt Lake City, UT by Konopacki and Akbari $(2002,2000)$.

The PIER Buildings area funded Lawrence Berkeley National Laboratory (LBNL) to monitor actual performance of a carefully selected assortment of California buildings, so savings realized from implementing the Cool Roofs Program can be documented. Monitoring of buildings was necessary because peak savings from cool roof retrofits have not been well quantified: only limited building types (e.g., office and retail) have been monitored to date, and those under limited climate conditions. To determine the Program's effect, peak savings data for cool roof applications on different building types in the diverse California climate zones is needed.

\subsection{Report Organization}

This report is organized in the following manner:

Section $1.0 \quad$ Introduction

Section 2.0 Energy Benefits and Environmental Impacts of Cool Roofs

Section $3.0 \quad$ Project Approach

Section 4.0 Methodology for Estimating Cooling Energy and Power Savings

Section 5.0 Project Outcomes

Section 6.0 Summary, Conclusions, and Recommendations

Appendix A. Building Recruitment Letter

Appendix B. Methodology to Extrapolate Savings from Application of Cool Roofs

Appendix C. Extension of the Cool Roof Retrofit Deadline for 10 Buildings 


\subsection{Energy Benefits and Environmental Impacts of Cool Roofs}

\subsection{Benefits}

Roofs that have high thermal emittance (high ability to radiate heat) and high solar reflectance (high ability to reflect sunlight) tend to stay cool in the sun. The same is true of low-emittance roofs with exceptionally high solar reflectance.3 Roofs that stay cool in the sun are hereafter denoted "cool roofs." Low roof temperatures lessen the flow of heat from the roof into the building, reducing cooling power demand in conditioned buildings. Since roof temperatures peak in late afternoon, when summer electricity use is highest, cool roofs can also reduce peak electricity demand.

Cool roofs transfer less heat to the air than do warm roofs. The resulting lower air temperatures can slow urban smog formation and increase human health and outdoor comfort. Reduced thermal stress may also increase the lifetime of cool roofs, lessening maintenance and waste.

\subsection{Environmental Impact}

Cool roofs are expected to have both positive and negative environmental impacts. Benefits include increased human comfort, slowed smog formation, and mitigation of urban heat islands in summer. Waste from disposal of roofs would also decrease. Penalties include slightly higher wintertime heating energy use, degraded wintertime urban air quality, and, in some cases, use of water and detergents to clean roofs.

\subsubsection{Environmental Benefits}

Cool roofs transfer less heat to the air than do warm roofs. The resulting lower air temperatures can slow urban smog formation and increase human comfort both outdoors and in unconditioned buildings. On a clear summer afternoon, the air temperature in a typical North American urbanized area can be about 2 to $9^{\circ} \mathrm{F}$ hotter than that in the surrounding rural area. The additional air-conditioning use induced by this urban air temperature elevation is responsible for 5 to $10 \%$ of urban peak electric demand, at a direct cost of several billion dollars annually. At the community scale, increasing the solar reflectance of roofs can effectively and inexpensively mitigate an urban heat island (Akbari et al., 2001).

Air temperature also has a significant influence on the formation of urban smog. Measured data and computer simulations studying the impact of temperature in Los Angeles smog show that a significant reduction in ozone concentration is achieved by lowering the ambient temperature. The simulations predict a reduction in population-weighted smog (ozone) of 10 to $20 \%$ resulting from a 3 to $4{ }^{\circ} \mathrm{F}$ cooling in ambient temperature. Cool roofs contribute about one-third of this

3 A low-emittance roof with exceptionally high solar reflectance can stay as cool as a white roof. For example, an unaged bare metal roof with a thermal emittance of 0.20 and a solar reflectance of 0.79 would under standard conditions have the same surface temperature as an unaged white roof with a thermal emittance of 0.75 and a solar reflectance of 0.70 . An even higher initial reflectance (in this case, 0.89 ) would be needed to match the surface temperature of the aged low-emittance roof to that of the aged high-emittance cool roof. 
reduction. For some scenarios, a 10 to $20 \%$ reduction in ozone is comparable to that obtained by replacing all gasoline on-road motor vehicles with electric cars (Rosenfeld et al., 1995).

Cool roofs may last longer than warm roofs due to reduced thermal stress. Thus, if installed in the course of either new construction or regularly scheduled roof replacement (i.e., once every 10 to 25 years), cool roofs would reduce waste and the need for landfill.

\subsubsection{Environmental Penalties}

Cool roofs tend to increase consumption of building heating energy. Of particular concern is the potential for cool roofs to increase gas-furnace emissions into local air districts where winter air pollution may be problematic. That is, if a building is cooled with remotely generated electric power, and heated with locally burned natural gas, installation of a cool roof may yield increased annual local emissions even while reducing annual energy consumption.

Small quantities of water and detergent may be used in cases where annual roof cleaning is required to maintain high reflectance. One contractor interviewed cleans roofs without detergent, using high-pressure water $\left(140 \mathrm{gal} / 1000 \mathrm{ft}^{2}\right)$ and baking soda $\left(0.5 \mathrm{lb} / 1000 \mathrm{ft}^{2}\right)$ to wash the roofs and neutralize acidic pollutants (Lease, 2002). 


\subsection{Project Approach}

The project approach included selecting buildings for monitoring, designing and installing the monitoring systems for the selected buildings, collecting base-case (pre-retrofit) data, coordination during the of cool roof installations, collecting cool roof (post-retrofit) data, estimating electricity and peak demand savings, and extrapolating savings to other California climate zones.

\subsection{Selection of Buildings to Monitor}

We obtained a weekly database of buildings participating in the Energy Commission's cool roof rebate program from its Regional Program Administrators (contractors). We reviewed the characteristics of these buildings and selected an initial subset for further investigation. Then we contacted the selected buildings for more information and availability for monitoring. Although over 200 building sites were interviewed, only a few buildings offered promising monitoring potentials. In some cases, we also visited the potential candidate sites. Upon selecting the candidate buildings, we obtained approval from the Energy Commission project manager to monitor the candidate buildings.

Our criteria for building selection were designed to ensure that buildings chosen would be practical to monitor. These included

1. Existing roof is dark;

2. To be retrofit with a cool roof in mid-summer (ideally in early July);

3. Single story;

4. Roof area $9,000-200,000 \mathrm{ft}^{2}$;

5. Roof insulation $\leq \mathrm{R}-19$;

6. No roof insulation to be added; and

7. A/C used year-round, or at least June-September.

The existing roof had to be dark; otherwise, a cool-roof retrofit would not yield measurable cooling savings. The retrofit had to be scheduled for mid-summer to allow for 4-6 weeks of summer weather both before and after the retrofit. Single story buildings were preferred because changes in roof reflectance affect only the top floor of a multi-flight building, and it is not always possible to separate the building cooling loads by floor.

A roof area of 9,000-200,000 $\mathrm{ft}^{2}$ was specified to ensure that the roof area retrofitted would be large enough to produce a measurable energy savings, but small enough to be easily monitored. (Very large buildings require significantly more effort and monitoring hardware.) Roof insulations levels of R-19 or lower were specified to ensure that the savings would be measurable, and buildings to which insulation was to be added to the roof were excluded because it would be difficult to differentiate cooling savings produced by the increase in roof reflectance from those yielded by the increase in roof insulation. Finally, the building had to be air conditioned so that there would be cooling savings to measure.

Previous studies have measured cool-roof retrofit savings for two office buildings, one retail store, and one school in northern California (N. CA); and no buildings in southern California (S. 
CA). Our goals in building selection were intended to fill the gaps in availability of retrofit data by building type (e.g., office, school, industrial) and location (primarily N. CA vs. S. CA, but also inland vs. coastal) by monitoring up to 10 buildings. Buildings types of particular interest included industrial, cold storage, and warehouse, anywhere in the state; and office, retail, and school in S. CA.

Table 1 shows our initial goals for building recruitment, in which we sought:

- Two cold storage facilities, one in N. CA and another in S. CA;

- Two industrial facilities, one in N. CA and another in S. CA;

- Two office buildings in S. CA;

- Two "other"-type buildings, one in N. CA and another in S. CA;

- Two retail store buildings in S. CA, one in N. CA and another in S. CA;

- One school in S. CA;

- Two warehouses, one in N. CA and another in S. CA.

This was by definition over ambitious, since it would entail monitoring 13 buildings, but it was intended to seek too many buildings, rather than too few, in case one or more buildings dropped out of our program. We planned to monitor only a subset of these buildings.

\subsection{Design of Monitoring System}

- Ensure that the selected building was indeed suitable for monitoring. A few of the potential buildings were dropped after the initial visit.

- Determine the required monitoring equipment and related specifications and cost. Typical measurement points and instrumentation are summarized in Table 2.

- Prepare a monitoring plan appropriated for the specific building site.

3.3. Monitoring System Specification, Procurement, Installation, Commissioning, and Maintenance

- Based on the monitoring plan specific to the building, we then:

- Procured the monitoring equipment and instrumentation

- Commissioned and tested equipment in the lab before installation

- Installed sensors and data-logging equipment on the selected buildings

- Commissioned and calibrated sensors and data-logger

- Measured current roof albedo of the selected building, and

- Audited the site by collecting building and HVAC system data. 
Table 1. Initial goals for building selection, shown by type and location.

\begin{tabular}{|l|l|l|l|l|l|l|l|}
\hline & \multicolumn{2}{|l|}{ Northern CA } & \multicolumn{3}{l|}{ Southern CA } \\
\hline Building Type & $\begin{array}{l}\text { previously } \\
\text { measured }\end{array}$ & $\begin{array}{l}\text { to } \\
\text { measure }\end{array}$ & total & & $\begin{array}{l}\text { previously } \\
\text { measured } \\
\text { measure }\end{array}$ & total \\
\hline cold-storage & 0 & 1 & 1 & & 0 & 1 & 1 \\
\hline industrial & 0 & 1 & 1 & & 0 & 1 & 1 \\
\hline multi-family & $2^{*}$ & 0 & 0 & & 0 & 0 & 0 \\
\hline Office & 2 & 0 & 2 & & 0 & 2 & 2 \\
\hline Other & 0 & 1 & 1 & & 0 & 1 & 1 \\
\hline Retail & $1^{* *}$ & 1 & 1 & & 0 & 1 & 1 \\
\hline School & 1 & 0 & 1 & & 0 & 1 & 1 \\
\hline warehouse & 0 & 1 & 1 & & 0 & 1 & 1 \\
\hline
\end{tabular}

* = single-family residence

$* *=$ roof had radiant barrier

new buildings needed 13 
Table 2. Typical measurement points and instrumentation.

\begin{tabular}{|c|c|c|}
\hline Measurement Point & Purpose & Sensors \\
\hline Building electrical energy use & Total building energy use & $\begin{array}{l}\text { 3-phase power } \\
\text { transducer }\end{array}$ \\
\hline HVAC electrical energy use & Building cooling energy use & $\begin{array}{l}\text { 3-phase power } \\
\text { transducer }\end{array}$ \\
\hline 3 roof surface temperatures & Roof Surface Temperature & Type T thermocouple \\
\hline 3 roof underside temperatures & Heat flux & Type T thermocouple \\
\hline 3 underside air temperatures & Correct for pre/post conditions & AD592 \\
\hline Outdoor dry-bulb temperature & Roof surface conduction & $\begin{array}{l}\text { RTD in Gill radiation } \\
\text { shield }\end{array}$ \\
\hline Outdoor relative humidity & $\begin{array}{l}\text { Sky temperature, roof surface re- } \\
\text { radiation }\end{array}$ & $\begin{array}{l}\text { Capacitive sensor in Gill } \\
\text { radiation shield }\end{array}$ \\
\hline Indoor dry-bulb temperature & Correct for pre/post conditions & AD592 \\
\hline Horizontal insolation & Roof heat gain & Silicon pyranometer \\
\hline
\end{tabular}




\subsection{Base-Case Data Collection, Review, Analysis and Troubleshooting}

For each building monitored, we:

- Developed a system to download data on a regular basis (typically daily)

- Developed software for quasi-real time analysis and review of the data

- Checked the range of data collected and then archived data weekly

- Tested the data acquisition system (DAS) to insure data quality, and

- Established pre-retrofit ("Pre") energy use base-line and peak power demand before the cool roof was installed.

\subsection{Coordination During Cool Roof Installations}

Coordination of the cool roof installation was critical to maintaining the integrity of the data monitoring. For those roofs that were coated, the roof temperature and heat flux sensors could remain in place, but the roofing contractor was informed to be careful not to displace the sensors. Even so, a couple of sensors at one site (Kaprielian Brothers Packing) had to be reinstalled due to wires being dislodged during roof coating. For those roofs that were covered with a membrane, the sensors had to be removed and reinstalled during re-roofing. This required close coordination with the roofing contractor as special boots had to be placed to allow for wiring to the sensors. Following installation of the cool roofing material or coating, we measured the final roof albedo.

\subsection{Cool Roof Data Collection, Review, Analysis and Troubleshooting}

After the installation of new roofs, we:

- Downloaded data on a regular basis (typically daily)

- Performed a quasi-real time analysis and review of the data

- Checked the range of data collected and then archived data weekly

- Retested the data acquisition system (DAS) to insure data quality

- Reviewed the collected data to ensured that sufficient data were obtain for the postretrofit period ("Post") for energy use and peak power demand after installing cool roofs

- Analyzed data to quantify peak demand and energy savings.

\subsection{Estimation of Electricity and Peak Demand Savings}

A detailed analysis of pre- and post-retrofit data was performed in order to quantify savings in the cooling-electricity use and peak demand. The analysis included:

Regression and comparison of pre- and post-retrofit data for roof surface temperature, underroof surface temperature, attic (air space) temperature, ceiling temperature, and indoor air temperature. The comparisons were performed for both hourly and daily data. 
Regression and comparison of pre- and post-retrofit air conditioning electricity use. Both hourly and daily data were used. The data were also normalized for outdoor and indoor air temperature for pre- and post-retrofit periods.

\subsection{Extrapolation of Savings}

\subsubsection{Analysis Plan for Extrapolation of Savings}

The objective of this task was to develop a methodology for extrapolating savings determined from the limited number of monitored buildings to similar buildings in other climate regions. To accomplish this, we prepared a memo addressed to the Energy Commission Contract Manager (Appendix A) in which we:

- Documented the methodology used to model the building parameters (and their interaction with solar radiation) that are important to accurately evaluate the thermodynamics of cool roof systems.

- Provided a summary of the existing state of the DOE2 computer algorithm that will be updated in this contract.

- Documented the improvements planned, including how empirical information collected during the building monitoring will be used in the derivation of scaling factors.

- Documented how calculated scaling factors will be used to estimate peak demand and energy use savings for other buildings participating in the Energy Commission's Cool Roofs program that were not monitored as part of this contract. The intent of this effort was not to develop a detailed function to model the complete heat transfer process through the roof, but to perform a quick comparison between the simulated energy use and the measured data. Here, scaling factors were developed through comparison of measured and simulated data. 


\subsection{Methodology for Estimating Cooling Energy and Power Savings}

\section{1. $\quad$ Adjusting Measured Savings}

In our experiments, we planned to monitor building cooling energy use for about one month (Pre-period); coat the roof with reflective (cool) materials; and continue monitoring for at least another month (Post-period). To estimate cooling energy savings, we use daily electricity use data for air conditioners and chillers. The cooling energy savings resulting from the application of cool roofs are simply the difference between the average energy use during the Pre and Post periods. However, for most cases, this simplified method may not result in an accurate estimate. There are three issues:

(1) The internal loads of the buildings during the Pre and Post periods may vary;

(2) The inside temperature and operational conditions may vary; and

(3) The weather conditions (including solar intensity) during the Pre and Post periods may vary.

To obtain an accurate estimate of savings, the cooling energy use during the Pre and Post periods must be adjusted for the above variations.

\subsubsection{Issue 1}

To account for the changes in the internal loads, we compared cooling energy use data for Pre and Post periods with comparable non-cooling electricity uses.

\subsubsection{Issue 2}

To account for the changes in inside temperature and operational conditions, we regressed the daily cooling energy use to $\Delta \mathrm{T} \equiv\left(\mathrm{T}_{\text {out }}-\mathrm{T}_{\text {in }}\right)$, since heat conduction through a building shell is typically proportional to temperature difference across the shell. ( $\mathrm{T}_{\text {out }}$ is the outdoor drybulb temperature and $\mathrm{T}_{\text {in }}$ is the indoor drybulb temperature.) However, in our analysis, we observed hourly cooling power demand correlated more strongly with $\mathrm{T}_{\text {out }}$ than with $\Delta \mathrm{T}$. This results from (a) thermal lag of the building envelop, (b) hourly variation in inside air temperature as occupancy fluctuates, and (c) the direct effect of $\mathrm{T}_{\text {out }}$ on $\mathrm{A} / \mathrm{C}$ efficiency (condenser temperature). Hence, we regressed hourly demand to $\mathrm{T}_{\text {out, }}$, rather than to $\Delta \mathrm{T}$.

\subsubsection{Issue 3}

To account for changes in weather between the Pre and Post periods, we assumed that the daily cooling energy use ( $\mathrm{E}_{\text {cooling }}$ ) is a function of internal load, insolation, and weather (outside wetbulb temperature, wind speed, and difference between outside drybulb temperature and inside temperature). We carried out a series of systematic regressions of the cooling electricity use for each period against outside temperature difference, outside wetbulb temperature, and wind speed. For most cases, the cooling electricity use showed significant correlation only to temperature difference $\Delta \mathrm{T}$. Its correlation to wetbulb temperature, wind speed, and solar intensity were statistically insignificant. Since adding other variables to the correlation did not 
improve the correlation statistics, we used $\Delta \mathrm{T}$ as the only weather parameter to correct the cooling electricity use for each period. Hence,

$$
\mathrm{E}_{\text {cooling }}=\mathrm{a}+\mathrm{b} \Delta \mathrm{T}
$$

Where:
$\mathrm{a}=\quad \mathrm{a}_{1}+\mathrm{a}_{2} \mathrm{I}$
$\mathrm{a}_{1}=\quad$ Cooling energy use for the internal loads [kWh/day $]$
$\mathrm{a}_{2}=\quad$ Coefficient of cooling use for solar load through the roof [dimensionless]
$\mathrm{I}=\quad$ Total daily solar energy (insolation) incident on the roof surface $[\mathrm{kWh} /$ day $]$
$\mathrm{b}=\quad$ Coefficient of cooling use for heat conduction and infiltration through the building envelop $\left[\mathrm{kWh} /\right.$ day $\left./{ }^{\circ} \mathrm{F}\right]$
$\Delta \mathrm{T}=\quad$ Daily average difference between outside and inside drybulb air temperatures $\left[{ }^{\circ} \mathrm{F}\right]$

Defining $\mathrm{E}_{\text {cooling, adjusted }}=\mathrm{E}_{\text {cooling }}-\mathrm{b} \Delta \mathrm{T}$ and using Eq. (1), we obtain:

$$
\mathrm{E}_{\text {cooling, adjusted }}=\mathrm{a}=\mathrm{a}_{1}+\mathrm{a}_{2} \mathrm{I} \text {. }
$$

Since we use data for periods with similar internal loads for the Pre and Post-period (i.e. $\mathrm{a}_{1, \mathrm{Pre}} \approx$ $\mathrm{a}_{1, \text { Post }}$, the average daily cooling energy savings resulting from the application of cool roofs are then estimated as

$$
\Delta \mathrm{E}=\mathrm{a}_{\text {Pre }}-\mathrm{a}_{\text {Post }}=\left(\mathrm{a}_{2} \mathrm{I}\right)_{\text {Pre }}-\left(\mathrm{a}_{2} \mathrm{I}\right)_{\text {Post }}
$$

In the above equation, $\mathrm{a}_{2}$ is proportional to the solar absorptance of the roof. Changing the roof solar absorptance from 0.8 (Pre) to 0.2 (Post) reduces roof solar heat gain by $75 \%$.

Daily insolation ( $\mathrm{kWh} /$ day) may change over the course of the monitoring period. However, since this period is about two months in summer, the average daily insolation during the Pre and Post period only varies by less than $10 \%$. Although in our regressions we do not observe a significant correlation to changes in the insolation (primarily because of a small range of variation in I), changes in solar intensity can introduce about $10 \%$ uncertainty in our estimate of savings.

Our methodology to estimate the peak demand savings in cooling electricity use is similar to that for estimating cooling electricity savings. We use hourly data for hours 10 am to $6 \mathrm{pm}$ (local time) to estimate the effects of cool roofs on peak demand. We report the average demand 
savings for these hours as the overall effect of cool roofs on peak demand. An analogous process applies when regressing hourly power demand $P_{\text {cooling }}(\mathrm{kW})$ to outside air temperature, $\mathrm{T}_{\text {out }}$.

It is important to note that the variation in the hourly electricity use data (hence, the uncertainty in the estimates of peak demand savings) is higher than that of the daily electricity use.

In summary, our methodology to estimate cooling energy and power demand savings is:

1. Select data for periods with similar non-conditioning electricity energy use (constant $\mathrm{a}_{1}$ )

2. Regress cooling energy use $\mathrm{E}_{\text {cooling }}$ against $\Delta \mathrm{T}\left(=\mathrm{T}_{\text {out }}-\mathrm{T}_{\text {in }}\right)$.

3. If the correlation between $\mathrm{E}_{\text {cooling }}$ and $\Delta \mathrm{T}$ is significant, adjust for the variations in $\Delta \mathrm{T}$ and estimate $\mathrm{E}_{\text {cooling, adjusted. }}$

4. Estimate the average daily cooling energy savings as $\Delta \mathrm{E}=\left(\mathrm{E}_{\text {cooling, adjusted }}\right)$ Pre $-\left(\mathrm{E}_{\text {cooling, adjusted }}\right)$ Post .

5. Regress cooling power demand $\mathrm{P}_{\text {cooling }}$ against $\mathrm{T}_{\text {out }}$.

6. If the correlation between $\mathrm{P}_{\text {cooling }}$ and $\mathrm{T}_{\text {out }}$ is significant, adjust for changes in $\mathrm{T}_{\text {out }}$ and estimate $\mathrm{P}_{\text {cooling, adjusted. }}$

7. Estimate the average daily cooling energy savings as $\Delta \mathrm{P}=\left(\mathrm{P}_{\text {cooling, adjusted }}\right)$ Pre $-\left(\mathrm{P}_{\text {cooling, adjusted }}\right)$ Post .

\subsection{Simulating Savings in Various California Climate Zones}

For the school building and retail store building, we used a calibrated DOE-2 simulation to extrapolate savings for similar buildings in difference California climates (these climate zones are shown in Figure 1). The methodology is detailed in Appendix B.

For the cold storage facility, however, we used another technique. The current scientific version of DOE-2.1E has significant limitations in simulating ammonia chillers and simulating conditioning zones below $55^{\circ} \mathrm{F}$. Hence, to extrapolate the savings for the other climate zones, we used empirical correlations, assuming that the savings $(\mathrm{kWh} /$ day or peak $\mathrm{kW})$ are proportional to I $\Delta \rho$, where $\Delta \rho$ is the change in the solar reflectance of the roof, and $I$ is either daily insolation $\left(\mathrm{kWh} / \mathrm{ft}^{2} /\right.$ day) or peak insolation $\left(\mathrm{kW} / \mathrm{ft}^{2}\right)$. Using this correlation, and the monthlyaveraged solar intensity per day and the monthly-averaged peak solar intensity as the indicators, the savings for other months or other climates can be estimated from:

$$
\frac{\text { Savings }_{i}}{\operatorname{Savings}_{R}}=\frac{I_{i}}{I_{R}}
$$

where $i$ refers to the new period or location and $R$ refers to the measured reference values. 


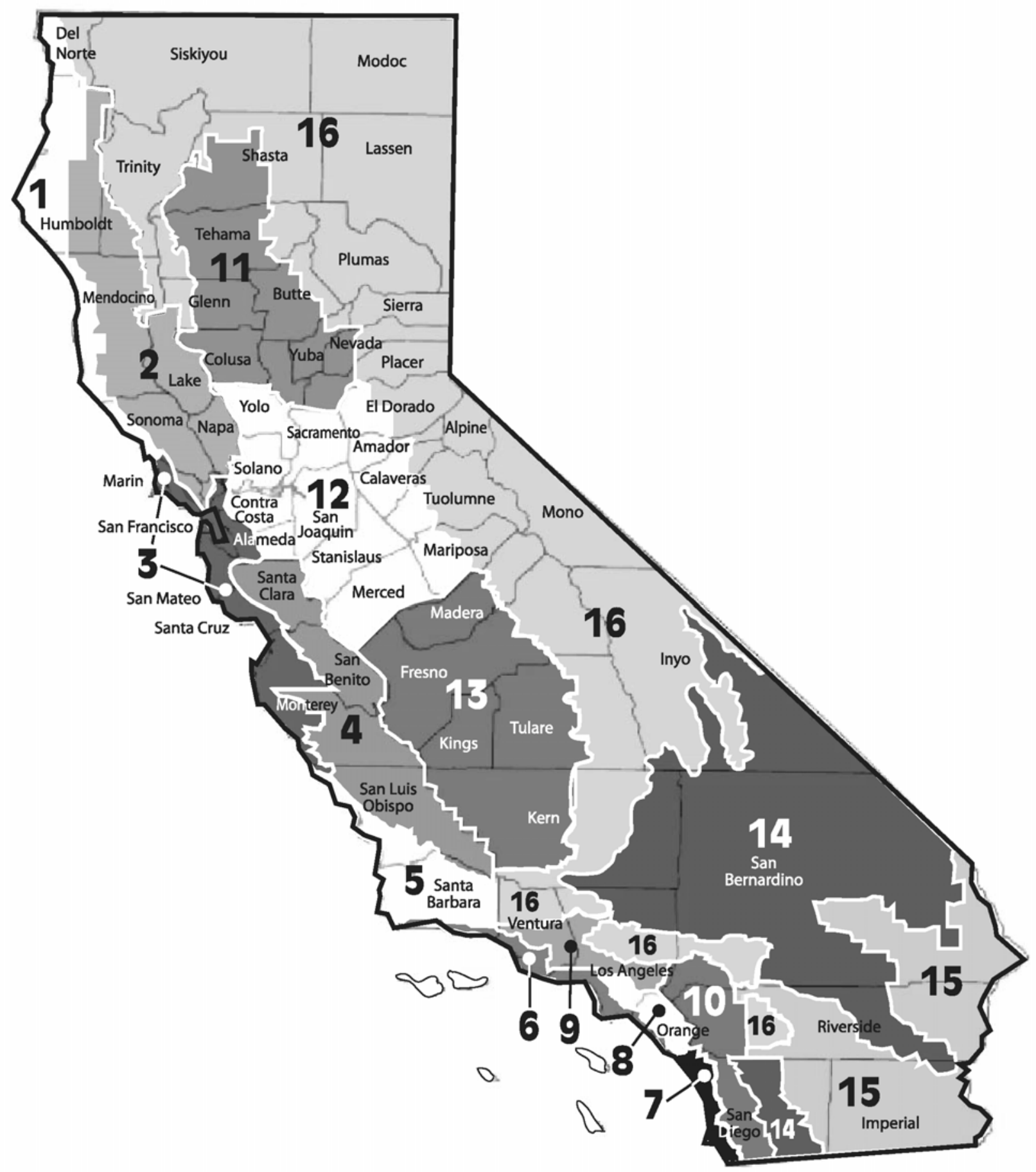

Figure 1. Locations of the 16 California Climate Zones. 


\subsection{Project Outcomes}

\section{1. $\quad$ Buildings Selected for Monitoring}

Recruiting building for monitoring was a six-step process involving

- establishing project goals and building-selection criteria;

- outreach;

- data mining;

- telephone interviews;

- $\quad$ site visits; and

- securing approval.

\subsubsection{Establishing Project Goals and Selection Criteria}

\subsubsection{Goals}

Presented in Project Approach.

\subsubsection{Criteria}

Presented in Project Approach.

\subsubsection{Outreach}

We sought buildings from several sources, but primarily focused on (a) the state's cool-roof rebate program and $(b)$ roofing contractors.

\subsubsection{Rebate Program}

The cool-roof rebate program was administered by four regional organizations: the Sacramento Tree Foundation (STF), the Sacramento Municipal Utility District (SMUD), the Los Angeles Department of Water and Power (LADWP), and the San Diego Regional Energy Organization (SDREO). We provided each regional administrator with a two-page handout (cover letter and FAQ, Appendix A) about the monitoring program that served to explain our program to both the administrator and to rebate-program participants. We asked the regional administrators to alert us to promising candidates, particularly those that appeared to be scheduled for a retrofit at right time (no later than early August, but at least 6 weeks in the future).

\subsubsection{Contractors}

We also worked directly with individual roofing contractors and groups of roofing contractors. LBNL has in the past cooperated with roofing contractors interested in the cool-roof retrofit market, such as Stockton Roofing (Stockton, CA). We alerted Stockton Roofing to our need for monitoring candidates, and they provided several leads, including two buildings that merited a site visit. We also presented our monitoring program to a group of 40 roofing contractors who had assembled at SMUD to learn about the cool-roof rebate program. 
It was common in the course of interviewing the building owners, property managers, and roofing contractors that had applied to the cool roof rebate program to find that a manager or contractor was planning to retrofit a series of buildings. We worked directly with such persons to identify buildings that would be retrofitted in the summer season but for which no application had yet been submitted to the state's rebate program.

\subsubsection{Data Mining}

The cool roof rebate program tracked applications with databases maintained by each administrative region. We sifted through these databases to locate promising candidates, as follows.

\subsubsection{Obtaining databases}

We requested databases and weekly updates thereof from each of the four administrative regions. Some administrators delivered updates with clockwork regularity, while others required prompting.

\subsubsection{Post-processing databases}

The regional databases were generally provided as Microsoft Access documents, though some were presented as Excel spreadsheets. Each of the four regions used a slightly different version of the database, typically because the region had chosen to insert additional data fields particular to its own operation. After we brought this issue to the attention of the rebate program, uniformity was increased, but regional differences remained.

The databases had to be coerced into a common format (i.e., given identical field structures) for purposes of aggregation. Hence, we exported each Access document's data table to an Excel spreadsheet, then manually inserted and/or deleted columns from each spreadsheet to achieve a common format. We also added a column of regional identifiers (e.g., Sacramento Tree Foundation (STF), Sacramento Municipal Utility District (SMUD)) to each spreadsheet in order to distinguish buildings in different regions that had been assigned the same ID number. This operation was repeated about once a week as updated databases were received from each region.

\subsubsection{Analyzing Databases}

The post-processed regional data were aggregated and copied into an Excel spreadsheet coded to analyze each building's eligibility. The analysis spreadsheet contained Boolean fields indicating whether or not each selection criterion was matched (e.g., roof area between 9,000 and 200,000 $\mathrm{ft}^{2}$ ), and another field that determined from zip code whether the building was in northern or southern CA. After Excel's autofilter function was employed to identify buildings that satisfied all the criteria, the potentially eligible buildings were disaggregated by type and location to produce lists of candidates (e.g., N. CA office buildings, S. CA cold storage facilities, etc.) to be interviewed by telephone. 


\subsubsection{Telephone Interviews}

We interviewed by telephone the contacts for about 250 buildings identified through (a) data mining or (b) leads provided by contractors and other helpful individuals

We called each building's contact (owner, manager, or contractor), briefly explaining our program and inquiring when the building would be reroofed. If the reroofing was scheduled for a time suitable for monitoring, we explained our program in greater detail and sent the contact our two-page handout by e-mail or fax. At this point we asked the contact to confirm the building information presented in the database, and inquired about building features relevant to monitoring that were not addressed in the rebate applicant database. For example, the presence of gas-powered industrial equipment (e.g., dryers) makes a building difficult to monitor, because measuring gas flow is more difficult and intrusive than measuring electrical current. This sort of detail was not included in the rebate applicant database because it was not relevant to the rebate program.

A typical phone interview would require one to three calls and some phone tag to make the initial contact. Some interviews were brief, particularly those in which we determined that the building had already been retrofitted, or was scheduled to be retrofitted within a few weeks. In the latter case, the contact was usually averse to rescheduling the retrofit, usually because a contract was in place. Over half of the buildings were eliminated for these reasons. Interviews that proceeded past this point typically took a total of 10-30 minutes, depending on the number of questions asked before either (a) LBNL or the contact disqualified the building from consideration or (b) the building "passed" the phone interview.

\subsubsection{Site Visits}

A small number of buildings (about a dozen) appeared sufficiently promising to warrant a halfday site visit by our subcontracted engineer (Leo Rainer of the Davis Energy Group). The engineer's surveyed the building's layout, construction, contents, operation, and cooling equipment; reviewed past utility bills; took photographs; and later prepared a brief report $(\sim 5$ pages) to be evaluated by LBNL. When possible, multiple site visits (e.g., to several buildings in the Los Angeles area) were bundled into a single trip from Davis for economy.

The site visits were invaluable because they often identified show-stopping building features gleaned neither from the database nor from the phone interviews, such as the presence of very high levels of roof insulation or a radiant barrier.

\subsubsection{Securing Approval}

Buildings that in LBNL's technical evaluation "passed" the site visit were considered suitable for monitoring. Once we obtained tentative agreement to participate from the building's owner or manager, we submitted a recommendation for inclusion to our program manager at the California Energy Commission. Once approved, the monitoring process could begin.

\subsubsection{Results}

We eventually recruited six buildings: a retail store in Sacramento; an elementary school in San Marcos (near San Diego); an office building in Irvine; and a cold storage facility in Reedley (near 
Fresno) that included a cold storage building, a conditioning and fruit-palletizing area, a conditioned packing area, and two unconditioned packing areas.

\subsubsection{Additional Considerations}

Building recruitment involved two difficult tasks: first, locating a suitable building; and second, persuading the building owner or manager to participate in our program. While the cost of monitoring was borne entirely by the study, participation typically posed some inconvenience to participants, such as adjusting the retrofit schedule or tying up some building space. We offered several incentives to encourage participation. First, we offered to document the energy savings, which is something that (a) we would naturally do in the course of the study and (b) appealed strongly to owners and managers who wanted to justify their decisions to install cool roofs. Second, we appealed to their senses of good citizenship, which was a modest at best. Third, we obtained written authorization from the Commission to extend the summer-2000 rebate rate of $\$ 0.20 / \mathrm{ft}^{2}$ to all buildings participating in our study (see Appendix C.), even if the retrofit took place after summer 2000, at which point the regular rebate had been reduced to $\$ 0.15 / \mathrm{ft}^{2}$. This $\$ 0.05 / \mathrm{ft}^{2}$ premium was a powerful incentive, since it was worth $\$ 1,000$ for a $20,000 \mathrm{ft}^{2}$ building.

Our building-recruitment experience was dominated by several somewhat disconcerting themes. First, our ability to locate suitable candidates was severely hampered by the tendency of building representatives to apply to the rebate program just before or just after the scheduled retrofit. This made it very difficult to find buildings that would be retrofitted in, say, two months, the minimum period of time required to visit a site, secure approval from all parties, install monitoring equipment, and gather pre-retrofit data for 4-6 weeks. Second, about half of the site visits led to disqualification, usually because the visit turned up a surprise feature. Third, since the monitoring-program participants were under no contractual obligation, it was possible for them to withdraw from the program at any time, even during the monitoring process. This did in fact occur with our S. CA office building. Because the economy was bad, the building manager repeatedly postponed the retrofit for over a year, and eventually elected not to install a cool roof.

\subsection{Monitoring and Analysis of Cool Roofs}

\subsubsection{Retail Store in Sacramento}

\subsubsection{Building Description}

The Carpeteria Flooring Center, located in Sacramento, was selected as the Northern California retail monitoring site (see Figure 2, Figure 3(a-d)). The building is a 17,000 $\mathrm{ft}^{2}$ single story concrete tilt-up building. The interior area consists of $9,000 \mathrm{ft}^{2}$ of sales floor, 1,900 $\mathrm{ft}^{2}$ of office, and 5,000 $\mathrm{ft}^{2}$ of warehouse. The Sales floor is mostly open with $16^{\prime}$ high ceilings, with a portion of dropped 10' t-bar ceiling. The office is all t-bar or sheetrock ceiling and the warehouse is all open. The open areas are insulated with multi-layer radiant barrier. The t-bar ceiling has 10" of fiberglass batt on top of the ceiling tiles and nothing at the roof. The roof consists of a plywood deck covered with a gray mineral cap sheet in very poor shape (it was installed in 1989) with a reflectance of $21 \%$ (see Figure $3 \mathrm{e}$ ). The roof reflectance increased to over $80 \%$ after covering the roof with an elastomeric coating (see Figure 3f). All spaces except the warehouse section are 
conditioned with gas-pack roof top units (RTUs); five are 5-ton units and one is a 3-ton unit. Two of the RTUs have exposed duct work on the roof.

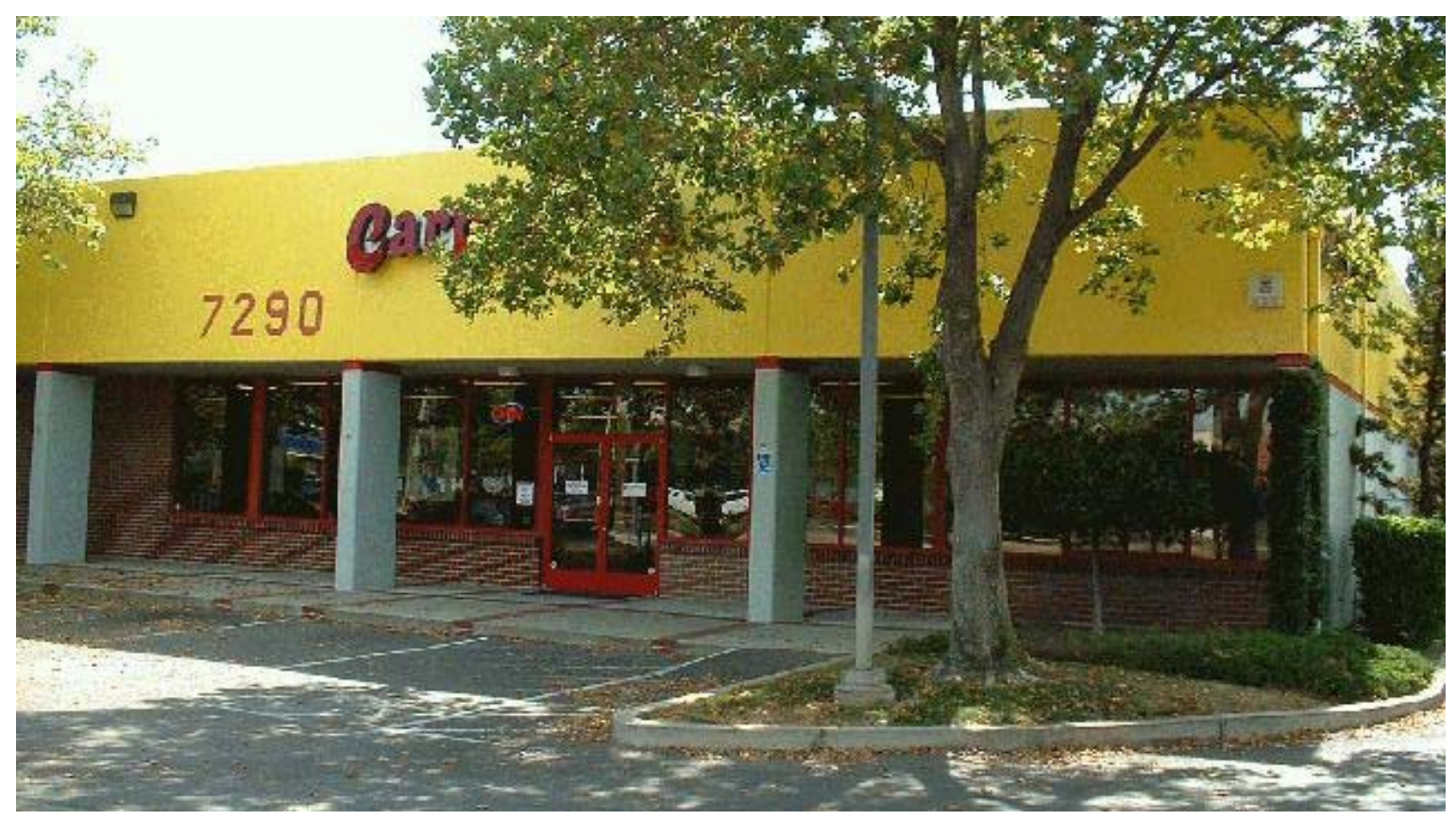

Figure 2. Carpeteria Flooring Center in Sacramento: Exterior. 


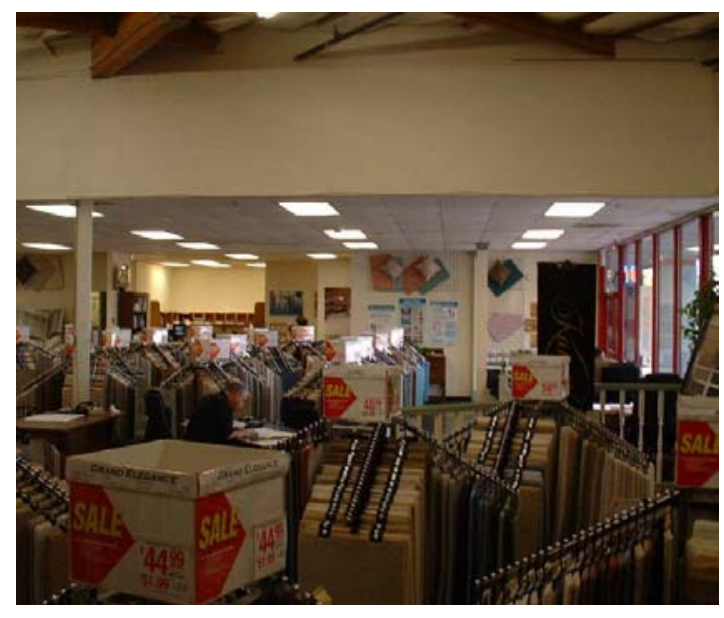

(a)

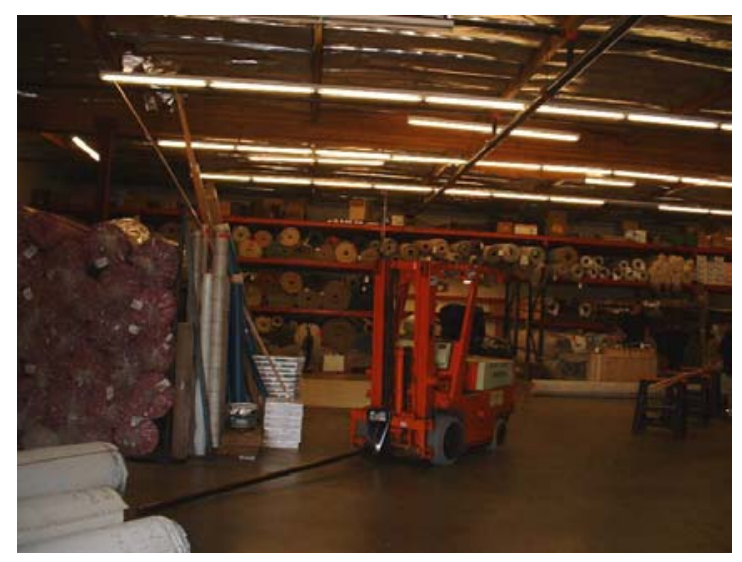

(c)

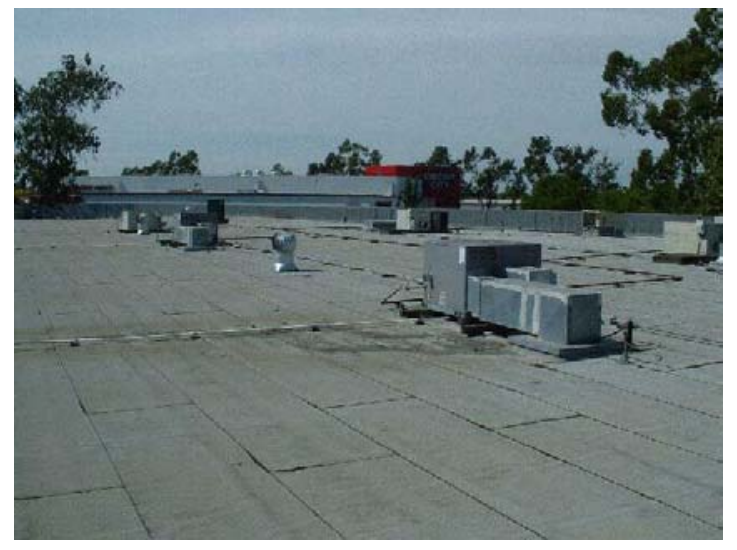

(e)

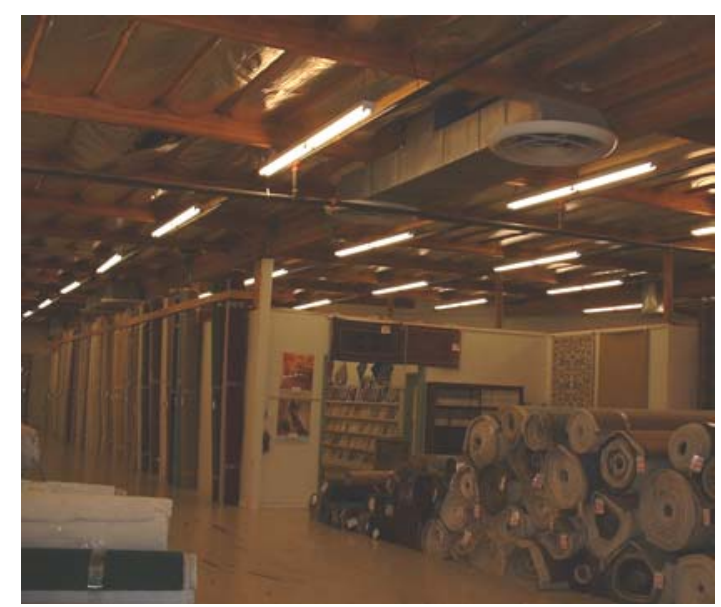

(b)

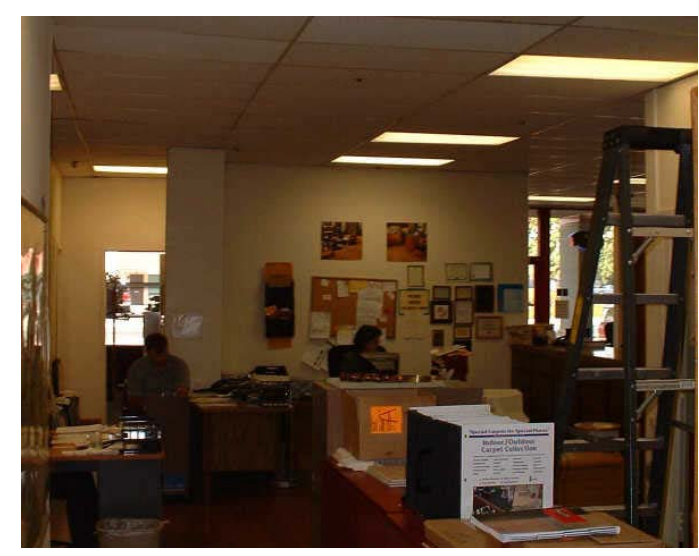

(d)

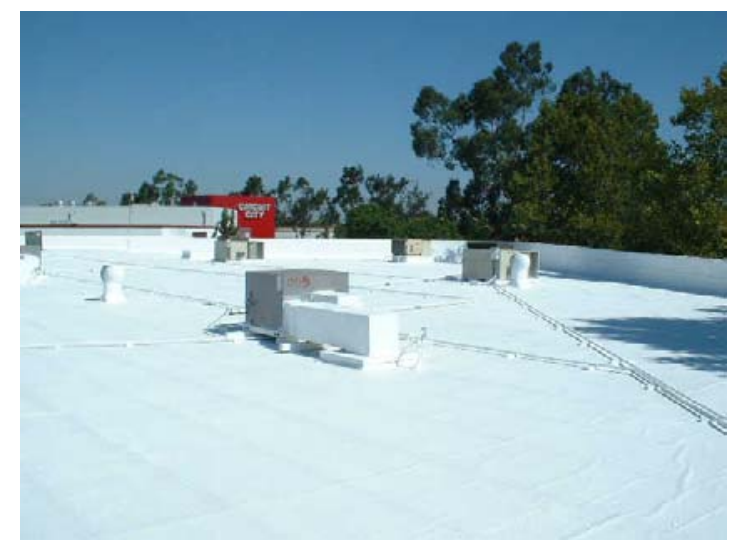

(f)

Figure 3. Carpeteria Flooring Center in Sacramento: (a) showroom, dropped ceiling; (b) showroom, open ceiling; (c) warehouse; (d) office; (e) roof before coating; and (f) roof after coating. 


\subsubsection{Instrumentation and Data Acquisition Systems}

Monitoring data were collected for approximately one month before and after installation of the reflective roof. Parameters that were measured to assess cool roof performance include:

- Roof surface temperatures

- Roof underside temperatures

- Indoor and plenum air temperatures

- Weather conditions

- Building energy use.

Table 3 summarizes the monitoring points and Figure 4 shows their locations.

Roof albedo was measured using ASTM E1918 - Standard Test Method for Measuring Solar Reflectance of Horizontal and Low-Sloped Surfaces in the Field (ASTM 1997) before and after roof coating, and at decommissioning (see Table 4). The two post-coating measurements were done with a very clean roof as the measurement on September $12^{\text {th }}$ was done just after coating and the measurement on November $14^{\text {th }}$ was done just after a rainstorm. Thus they do not reflect the effect of dirt build-up.

\subsubsection{Air Conditioning Systems and Building Operation Schedules}

The building is conditioned by six roof top package units of varying ages (see Table 5). All units are controlled by wall-mounted thermostats with setback capabilities but are operated manually. The building is occupied from 7:30 a.m. - 7:00 p.m. weekdays and 8:00 a.m. to 6 p.m. on weekends.

\subsubsection{Data Acquisition Approach}

All sensors were continuously scanned and were summed or averaged in datalogger memory every 15 minutes. The datalogger had battery backup to protect against data loss during power outages. Data were downloaded nightly and all data ranges were reviewed the next day. Outof-range data were reported and investigated to determine whether a sensor or monitoring error existed or equipment had failed. Data were collected by Davis Energy Group and files were transferred to LBNL weekly during the monitoring period. 
Table 3. Carpeteria Flooring Center in Sacramento: Building monitoring points.

\begin{tabular}{l|lll}
\hline No. & Name & Location & Purpose \\
\hline 1 & TRS-A & Roof surface above Office & Roof surface temperature \\
2 & TRS-B & Roof surface above Sales & Roof surface temperature \\
3 & TRS-C & Roof surface above Warehouse & Roof surface temperature \\
4 & TRU-A & Roof underside in Office & Roof underside temperature \\
5 & TRU-B & Insulation underside in Sales & Insulation underside temperature \\
6 & TRU-C & Insulation underside in & Insulation underside temperature \\
7 & TAP-A & Plenum in Office & \\
8 & TAI-A & Office & Plenum air temperature \\
9 & TAI-B & Sales & Interior air temperature \\
10 & TAI-C & Warehouse & Interior air temperature \\
11 & TAO & Weather tower & Interior air temperature \\
12 & RHO & Weather tower & Outdoor dry bulb temperature \\
13 & HSOL & Weather tower & Outdoor relative humidity \\
14 & WAC1 & Panel AC1 & Horizontal solar radiation \\
15 & WAC2 & Panel AC2 & Total A/C electricity use for RTU1-RTU5 \\
16 & WOTH & Panel A & A/C electricity use for RTU6 (office) \\
\hline
\end{tabular}




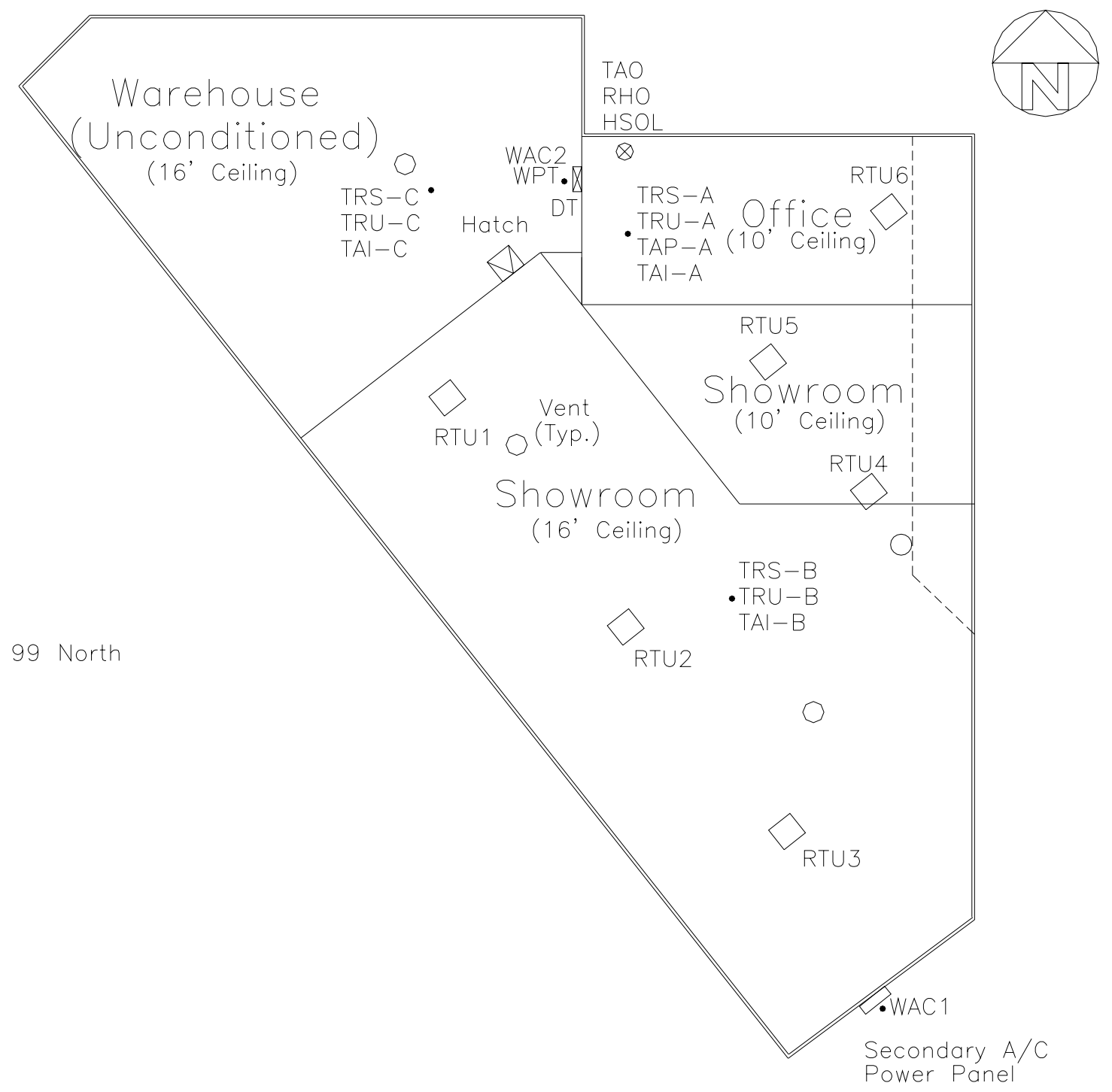

Figure 4. Carpeteria Flooring Center in Sacramento: Building floor plan. 
Table 4. Carpeteria Flooring Center in Sacramento: Roof albedo measurements.

\begin{tabular}{|c|c|c|c|c|c|c|}
\hline \multirow[b]{2}{*}{ Location } & \multirow[b]{2}{*}{ Notes } & & \multicolumn{3}{|c|}{ Measurement } & \multirow[b]{2}{*}{ Average } \\
\hline & & & 1 & 2 & 3 & \\
\hline \multicolumn{7}{|l|}{ Pre } \\
\hline \multirow[t]{3}{*}{1} & \multirow{3}{*}{$\begin{array}{l}\text { 7/18/02 3:00 } \\
\text { Clear, calm }\end{array}$} & $U p\left(\mathrm{~W} / \mathrm{m}^{2}\right)$ & 792 & 789 & 784 & 788 \\
\hline & & Down $\left(\mathrm{W} / \mathrm{m}^{2}\right)$ & 162 & 163 & 164 & 163 \\
\hline & & Albedo & $20 \%$ & $21 \%$ & $21 \%$ & $21 \%$ \\
\hline \multirow[t]{3}{*}{2} & & $U p\left(\mathrm{~W} / \mathrm{m}^{2}\right)$ & 803 & 799 & 803 & 802 \\
\hline & & Down $\left(\mathrm{W} / \mathrm{m}^{2}\right)$ & 167 & 167 & 171 & 168 \\
\hline & & Albedo & $21 \%$ & $21 \%$ & $21 \%$ & $21 \%$ \\
\hline \multicolumn{7}{|l|}{ Post } \\
\hline \multirow[t]{3}{*}{1} & \multirow{3}{*}{$\begin{array}{l}\text { 9/12/02 11:00 } \\
\text { Clear, light breeze }\end{array}$} & $U p\left(\mathrm{~W} / \mathrm{m}^{2}\right)$ & 625 & 625 & 640 & 630 \\
\hline & & Down $\left(\mathrm{W} / \mathrm{m}^{2}\right)$ & 513 & 512 & 517 & 514 \\
\hline & & Albedo & $82 \%$ & $82 \%$ & $81 \%$ & $82 \%$ \\
\hline \multirow[t]{3}{*}{2} & & $U p\left(\mathrm{~W} / \mathrm{m}^{2}\right)$ & 623 & 632 & 632 & 629 \\
\hline & & $\operatorname{Down}\left(\mathrm{W} / \mathrm{m}^{2}\right)$ & 525 & 530 & 529 & 528 \\
\hline & & Albedo & $84 \%$ & $84 \%$ & $84 \%$ & $84 \%$ \\
\hline \multicolumn{7}{|c|}{ Decommission } \\
\hline \multirow[t]{3}{*}{1} & \multirow{3}{*}{$\begin{array}{l}\text { 11/14/02 2:45 } \\
\text { High thin clouds, light breeze }\end{array}$} & $U p\left(\mathrm{~W} / \mathrm{m}^{2}\right)$ & 323 & 315 & 306 & 315 \\
\hline & & $\operatorname{Down}\left(\mathrm{W} / \mathrm{m}^{2}\right)$ & 268 & 253 & 256 & 259 \\
\hline & & Albedo & $83 \%$ & $80 \%$ & $84 \%$ & $82 \%$ \\
\hline \multirow[t]{3}{*}{2} & & $U p\left(\mathrm{~W} / \mathrm{m}^{2}\right)$ & 295 & 285 & 293 & 291 \\
\hline & & Down $\left(\mathrm{W} / \mathrm{m}^{2}\right)$ & 242 & 237 & 240 & 240 \\
\hline & & Albedo & $82 \%$ & $83 \%$ & $82 \%$ & $82 \%$ \\
\hline
\end{tabular}


Table 5. Carpeteria Flooring Center in Sacramento: Building HVAC units.

\begin{tabular}{l|lll}
\hline Unit \# & Model & $\begin{array}{l}\text { Capacity } \\
\text { (tons) }\end{array}$ & SEER \\
\hline 1 & Payne 584APW060080 & 5 & 9 \\
2 & BDP 588APW060080 & 5 & 9 \\
3 & BDP 588APW060080 & 5 & 9 \\
4 & Payne 584APW060080 & 5 & 9 \\
5 & Payne 584APW060080 & 5 & 9 \\
6 & York 01SE03604906A & 3 & 8 \\
\hline
\end{tabular}

\subsubsection{Datalogger and Sensor Specifications}

\section{Datalogger}

A Data Electronics DT50 datalogger mounted in a NEMA 1 box was installed next to the power distribution panels in the warehouse. The datalogger was provided with an RS232 communications interface, modem, and battery backup. A dedicated phone line was used for nightly download of the data. Shielded twisted-pair was used for all sensor cables. Exterior cable runs were brought into the building through the roof access hatch in the warehouse.

\section{Surface Temperatures}

All surface temperatures were measured with Minco RTD thermal ribbon sensors connected to the data logger with 4-20ma current transducers. Roof surface sensors were placed just under the roofing felt. Roof underside temperature was measured in the office. Insulation underside temperatures were measured in the sales and warehouse (see Figure 5).

\section{Air Temperatures}

Plenum air temperature above the office was measured in the middle of the plenum with a shielded AD592 semiconductor air sensor. Building interior temperatures were measured with a wall mounted AD592 semiconductor sensor placed next to the room thermostat (Figure 6).

\section{Weather Tower}

Three sensors were mounted to a weather tower mast attached to the roof parapet wall (see Figure 7). Outdoor dry bulb and relative humidity were measured with an R.M. Young $\mathrm{RH} /$ temperature probe mounted in a Gill multi-plate radiation shield. Total horizontal solar isolation was measured with a Li-Cor LI-200SZ silicon photodetector. 


\section{Power}

The building main panel feeds three sub-panels, A, B, and A/C, each of which was sub-metered (see Figure 8). Panel A feeds all of the building lights and plug loads. Panel A/C initially fed all of the building A/C loads, but has now been largely replaced by panel B. Panel A/C now only feeds the office RTU (\#6) and panel B feeds RTUs \#1-5. Power was measured with Continental Control Systems 3P-208 WattNode power transducers mounted inside the building electrical panels. Current was measured with $100 \mathrm{amp}$ Magnelab split-core current transformers.

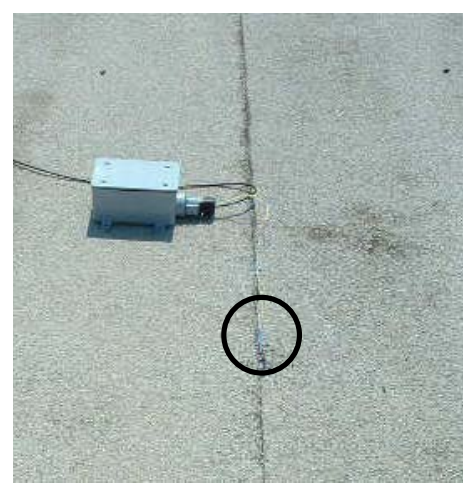

(a)

(b)
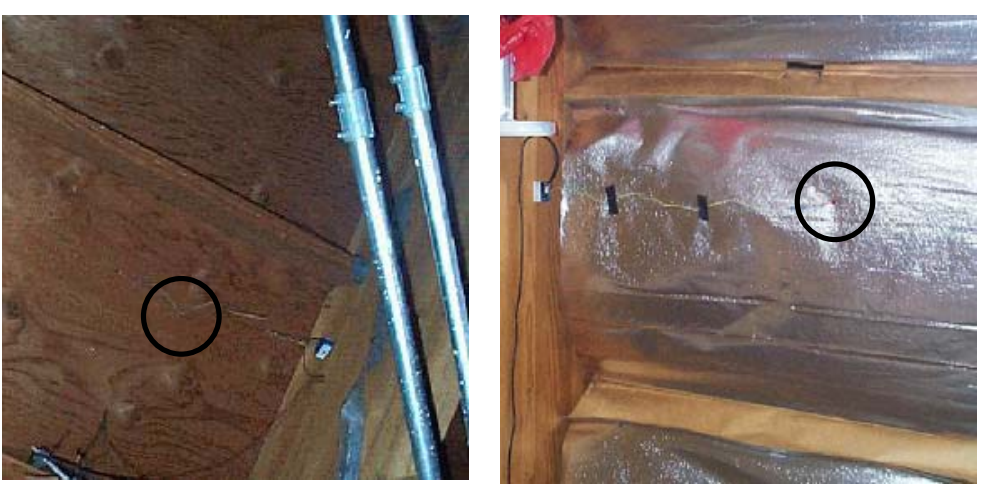

(c)

Figure 5. Carpeteria Flooring Center in Sacramento: Temperature sensors on (a) roof surface, (b) roof underside, and (c) insulation underside. 


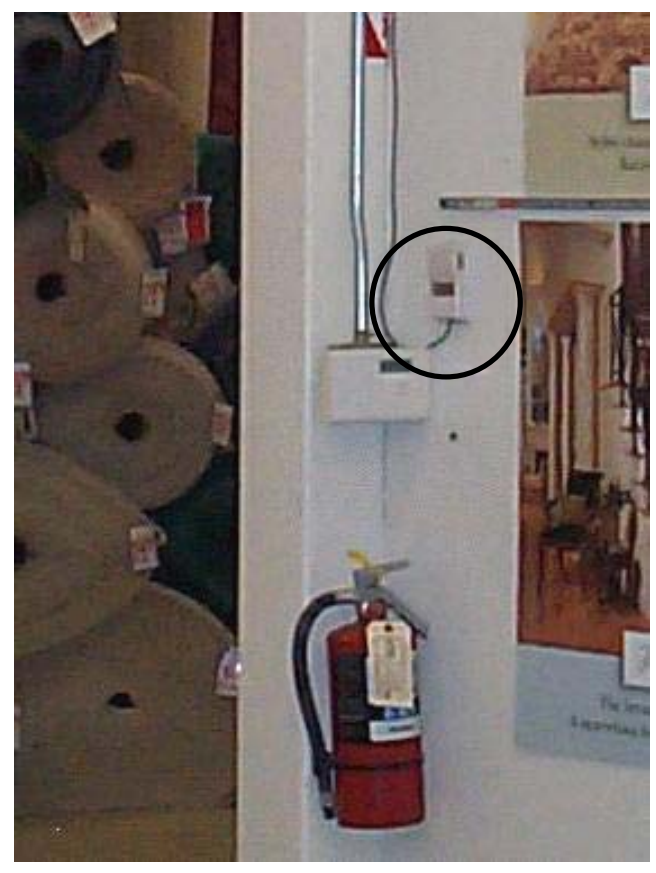

Figure 6. Carpeteria Flooring Center in Sacramento: Indoor air temperature sensor.

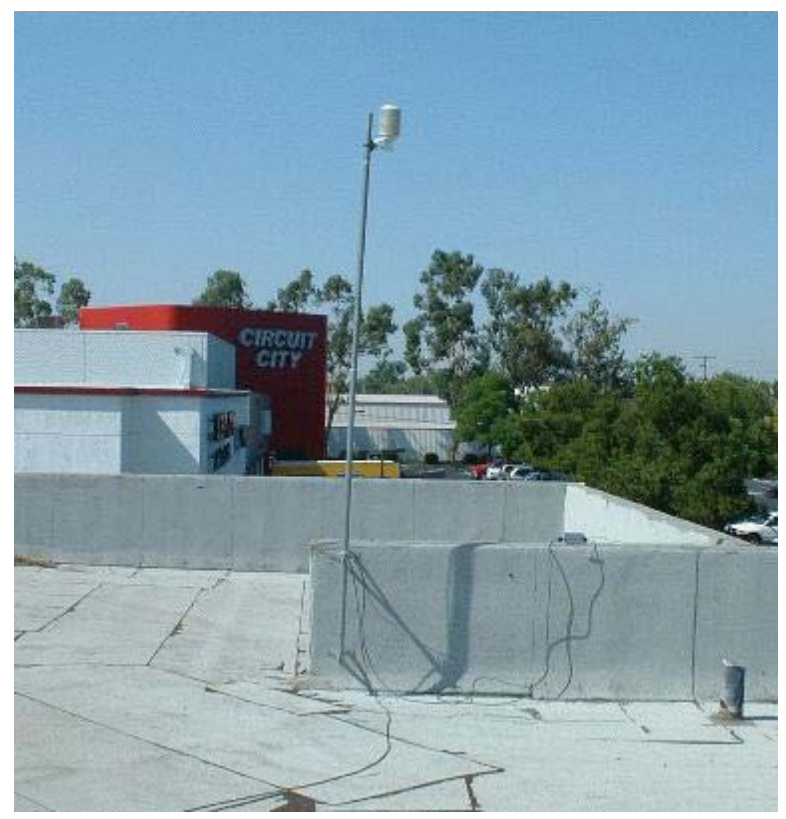

Figure 7. Carpeteria Flooring Center in Sacramento: Weather tower. 


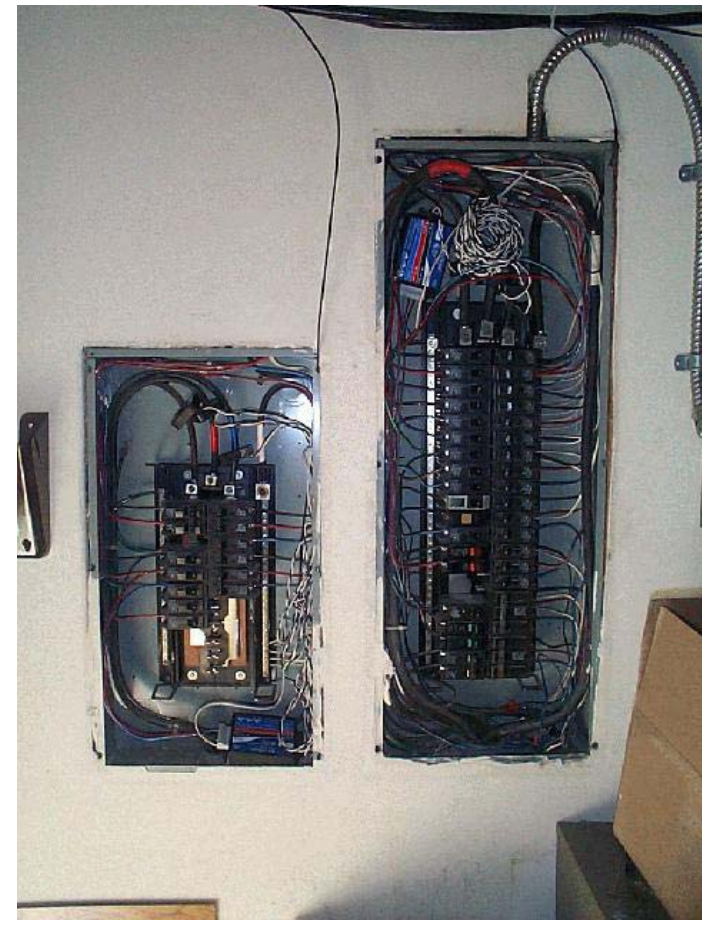

(a)

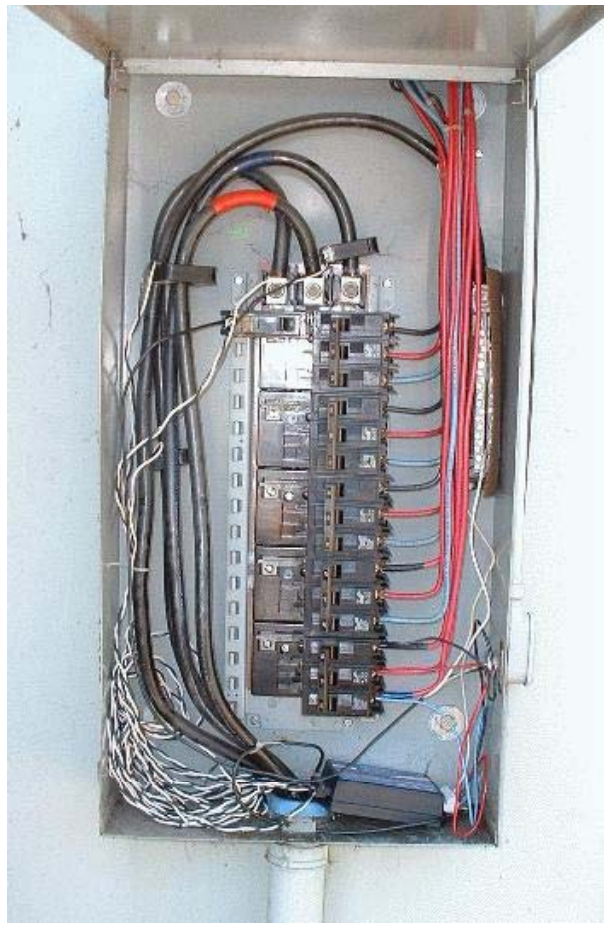

(b)

Figure 8. Carpeteria Flooring Center in Sacramento: Metered panels (a) panel A/C and panel A, and (b) panel B.

\subsubsection{Monitoring Period}

The instrumentation was installed on August 3-4, 2002. The system was debugged and data were calibrated during the period August 4-8, 2002. The pre-retrofit (Pre) data cover the period of August 8, to September 9, 2002 (32 days). The roof was coated during September 9 and 10. The post-retrofit (Post) data cover the period of September 11 - 30, 2002 (20 days).

\subsubsection{Data Analysis and Results}

The first step in the analysis was to aggregate the validated 15-minute data into hourly and daily data. This was done for solar intensity, cooling electricity use, and total building electricity use. The temperature data were averaged to yield hourly and daily variables. In this process, questionable and missing data were identified and excluded from the analysis.

The parameters that can affect air-conditioning electricity use include outside temperature, inside temperature, solar heat gain, internal loads, relative humidity, and wind speed. A systematic regression analysis was performed in order to determine the sensitivity of the airconditioning electricity use to these environmental parameters. The analysis was performed for the initial conditions before the roof was coated with a reflective white coating (defined as Pre period) and for the conditions after the roof was coated (defined as Post period). These regressions allowed normalizing the Pre and Post conditions for all parameters before making an attempt to estimate savings from the application of white coating. 


\section{Temperature Data}

Figure 9 shows hourly temperature data for a period of two weeks before and two weeks after the roof was coated on September 11, 2002. Figure 10 shows the corresponding hourly temperatures averaged over the Pre and Post periods. As Figure 10 shows the average outdoor hourly temperatures for the Pre and Post periods are remarkably similar. The maximum surface temperature in the Pre period is about $65^{\circ} \mathrm{F}$ higher than the ambient air temperature. For the Post period, the maximum surface temperature is only a few degrees higher than the ambient temperature. Hence, the maximum surface temperature elevation was reduced by about $60-65^{\circ} \mathrm{F}$ after coating the roof. The minimum nighttime surface temperature for the Pre and Post periods can get about $20^{\circ} \mathrm{F}$ cooler than ambient air temperature. This is mostly because of radiative nighttime cooling to the Sacramento clear sky.

The under-roof temperature in the conditioned area ' $\mathrm{A}$ ' (area with a plenum) is about $40-50^{\circ} \mathrm{F}$ higher in the Pre period compared to Post period. The air temperature in the plenum under area ' $\mathrm{A}$ ' is about $20-25^{\circ} \mathrm{F}$ higher in the Pre period compared to Post period. The under-roof temperature in the conditioned and unconditioned areas ' $\mathrm{B}$ ' and ' $\mathrm{C}$ ' (areas without a plenum) is about $15-20^{\circ} \mathrm{F}$ higher in the Pre period compared to Post period.

The inside temperature in both conditioned and non-conditioned areas appear to be a few degrees cooler in the Post period compared to Pre period. In fact, according to Figure 10, the daytime average indoor temperatures at locations ' $\mathrm{A}$ ' and ' $\mathrm{B}$ ' are about $1.5-2^{\circ} \mathrm{F}$ cooler in the Post period. In the unconditioned area (location $C$ ), the daytime average indoor temperature is about $3^{\circ} \mathrm{F}$ cooler in the Post period. 

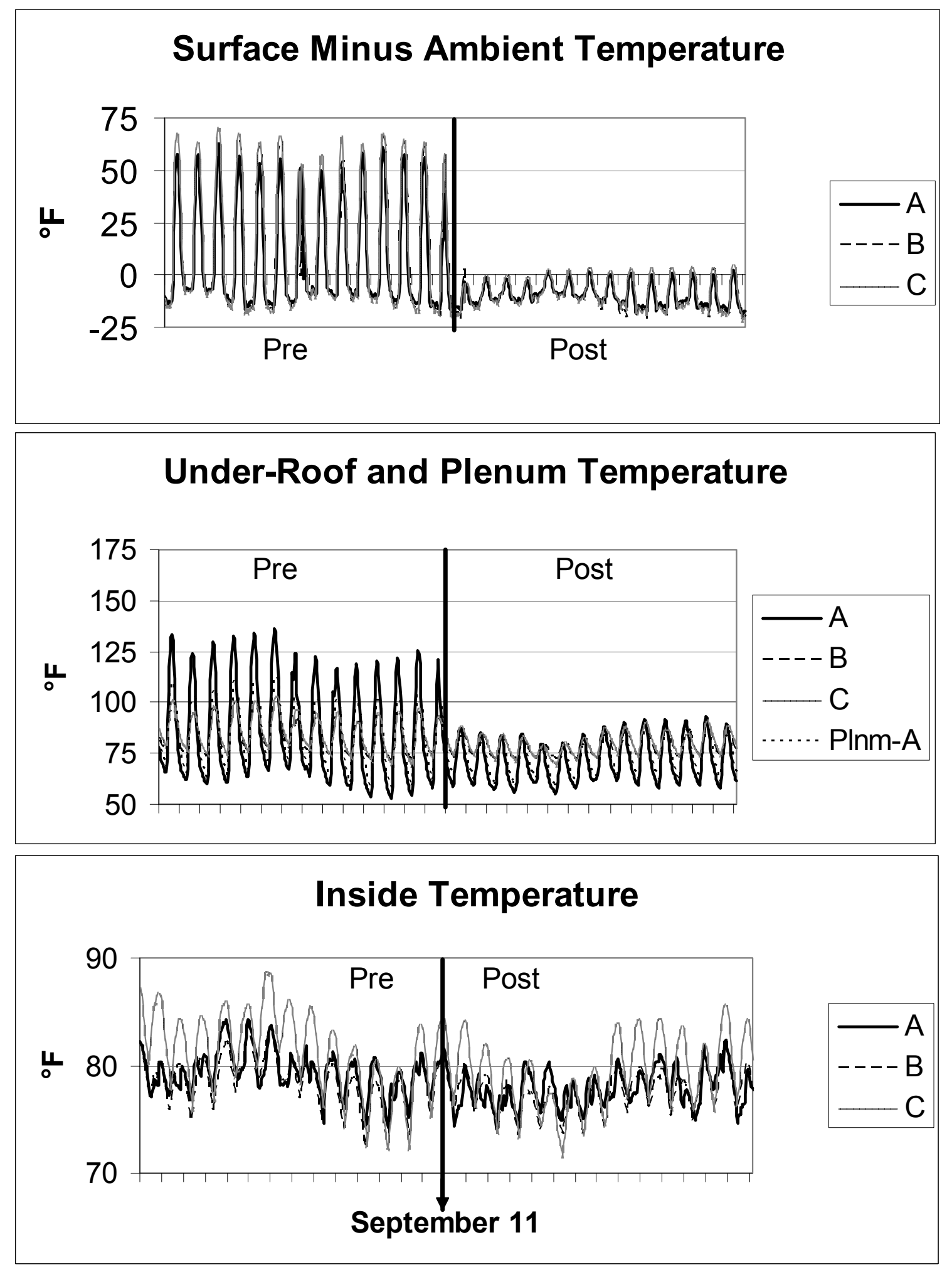

Figure 9. Carpeteria Flooring Center in Sacramento: Hourly temperatures for two-week periods before and after installation of a reflective roof coating on September 11, 2002. ' $A$ ', 'B', and 'C' are measurements at three locations on the roof. 'Plnm- $\mathrm{A}$ ' is the plenum air temperature at location ' $\mathrm{A}$ '. Time interval = day. 

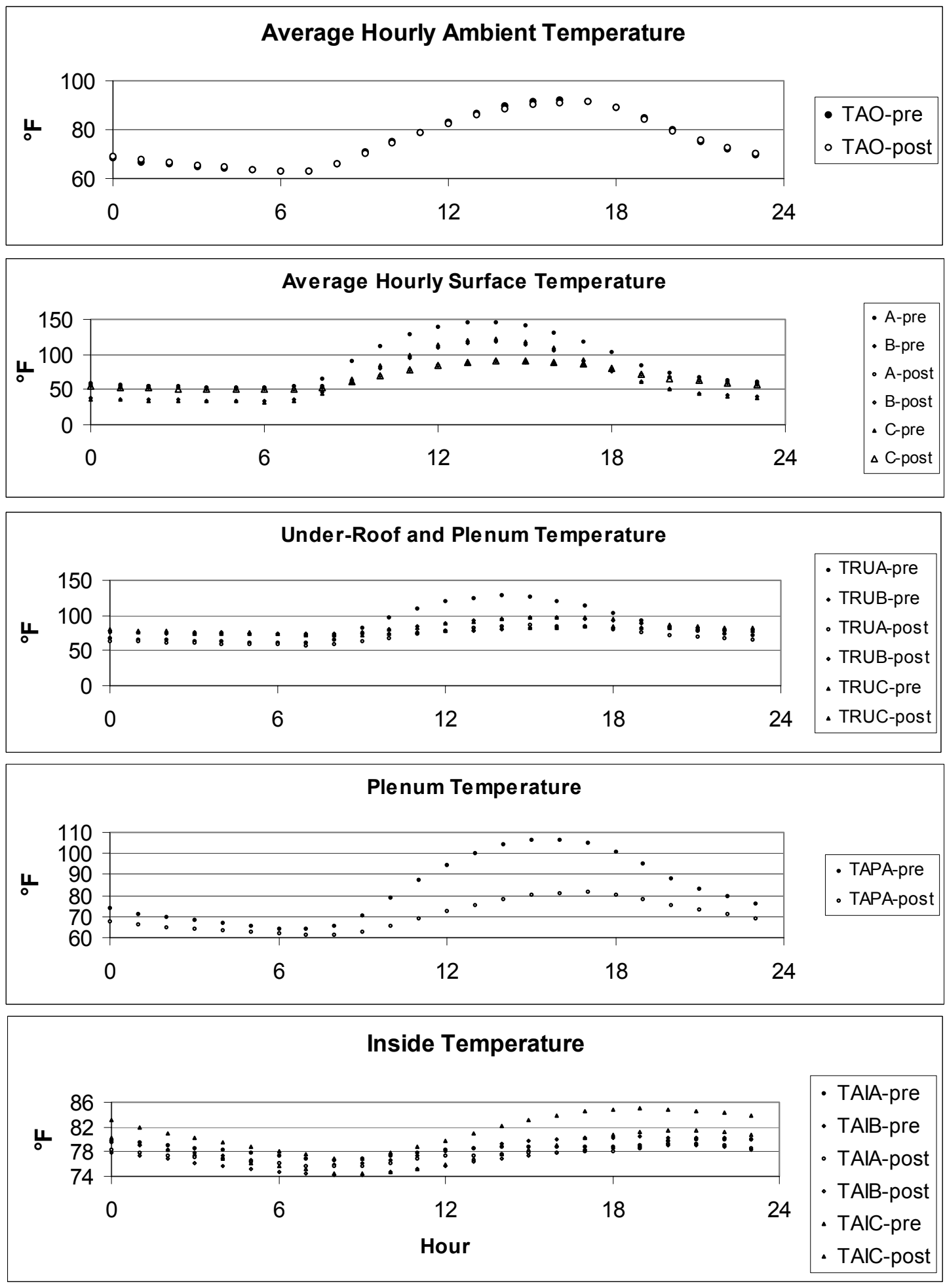

Figure 10. Carpeteria Flooring Center in Sacramento: Average hourly temperatures before (Pre) and after (Post) installation of reflective roof coating. ' $\mathrm{A}$ ', ' $\mathrm{B}$ ', and ' $\mathrm{C}$ ' are measurements at three locations on the roof; 'TRUA,' 'TRUB,' and 'TRUC' are under-roof temperatures at locations 'A', ' $\mathrm{B}$ ', and ' $\mathrm{C}$ ', respectively; 'TAPA' is plenum air temperature at location ' $\mathrm{A}$ '; 'TAIA,' 'TAIB,' and 'TAIC' are inside air temperature at locations ' $\mathrm{A}^{\prime}$, ' $\mathrm{B}$ ', and ' $\mathrm{C}$ ', respectively . 


\section{Air Conditioning Energy Use and Savings}

Figure 11 shows the hourly and daily electricity use for the air conditioning system 1 (AC1: RTU1 - RTU5), air conditioning 2 (AC2: RTU6, used in the office area), and the "other" (OTH: lighting, etc.) usages. The hourly data are shown for a period of two weeks before and after the installation of roof coating; the daily data are for the entire monitoring period (August 8 through September 30). The AC2 is a small unit used in the office area with a weekly schedule that is off on Saturdays and Sundays. The AC1 is the main air conditioning system used in the sales area. In the Pre period, the AC1 has a peak usage of about $35 \mathrm{~kW}$. During the Post period, for a similar outdoor temperature, the peak AC1 usage is about $18 \mathrm{~kW}$. This suggests a peak demand reduction of about $17 \mathrm{~kW}$ (slightly less than $50 \%$ !). We will statistically quantify peak demand savings later on.

The same impressive reduction can be observed in the daily electricity use data for AC1. For days with similar average temperature, the Pre AC2 usage is about $220 \mathrm{kWh} /$ day and for Post is about $120 \mathrm{kWh} /$ day. This also suggests savings of about $100 \mathrm{kWh} /$ day (slightly less than $50 \%$ !) on hot summer days. It is also noted that the both hourly and daily electricity use for OTH during Pre and Post period are similar, typically around $250 \mathrm{kWh} /$ day during the week days. During the daytime hours, the hourly OTH electricity use ranges from 13-15 kWh per hour. Figure 12 shows the daily air-conditioning electricity use for AC1 and AC2 as a function of the difference between outside and inside temperatures $\left(\Delta \mathrm{T}=\mathrm{T}_{\text {out }}-\mathrm{T}_{\text {in }}\right)$. We performed statistical analysis of A/C electricity use versus (a) difference between outside and inside temperatures $(\Delta \mathrm{T})$ and $(\mathrm{b})$ daily total insolation. The results showed significant correlation between the $\mathrm{A} / \mathrm{C}$ electricity use and temperature difference. The regressions against insolation were not statistically significant and did not improve the overall regression models. Table 6 summarizes the results of the regressions for temperature difference as independent variable.

Using the correlation in Table 6, we estimated the total air conditioning (AC1+AC2) daily electricity use for the building (see Table 7). During the Pre period, the daily average A/C use was $161 \mathrm{kWh}$ per day. During the Post period, the average daily A/C electricity use was 80 $\mathrm{kWh}$ per day. As we indicated earlier, the average outdoor temperature during the Pre and Post period was fairly similar. Hence, without correcting for weather conditions of the Pre and Post period, the savings are estimated at $81 \mathrm{kWh} /$ day (51\%). Using the difference of average outdoor and indoor temperatures, the savings were estimated at $94 \mathrm{kWh} /$ day and $105 \mathrm{kWh} /$ day $(58 \%$ and $57 \%$ ) for Pre and Post periods, respectively.

The daily A/C electricity savings increases with increasing outdoor temperature. When the average daily outdoor and indoor air temperatures difference $(\Delta \mathrm{T})$ is $7^{\circ} \mathrm{F}$ the estimated cooling electricity use is $273 \mathrm{kWh}$ /day and $129 \mathrm{kWh}$ / day for Pre and Post period, respectively. The estimated savings are $144 \mathrm{kWh}$ / day and $146 \mathrm{kWh} /$ day (53\%). Estimates by both methods indicate savings in excess of $50 \%$ ! 

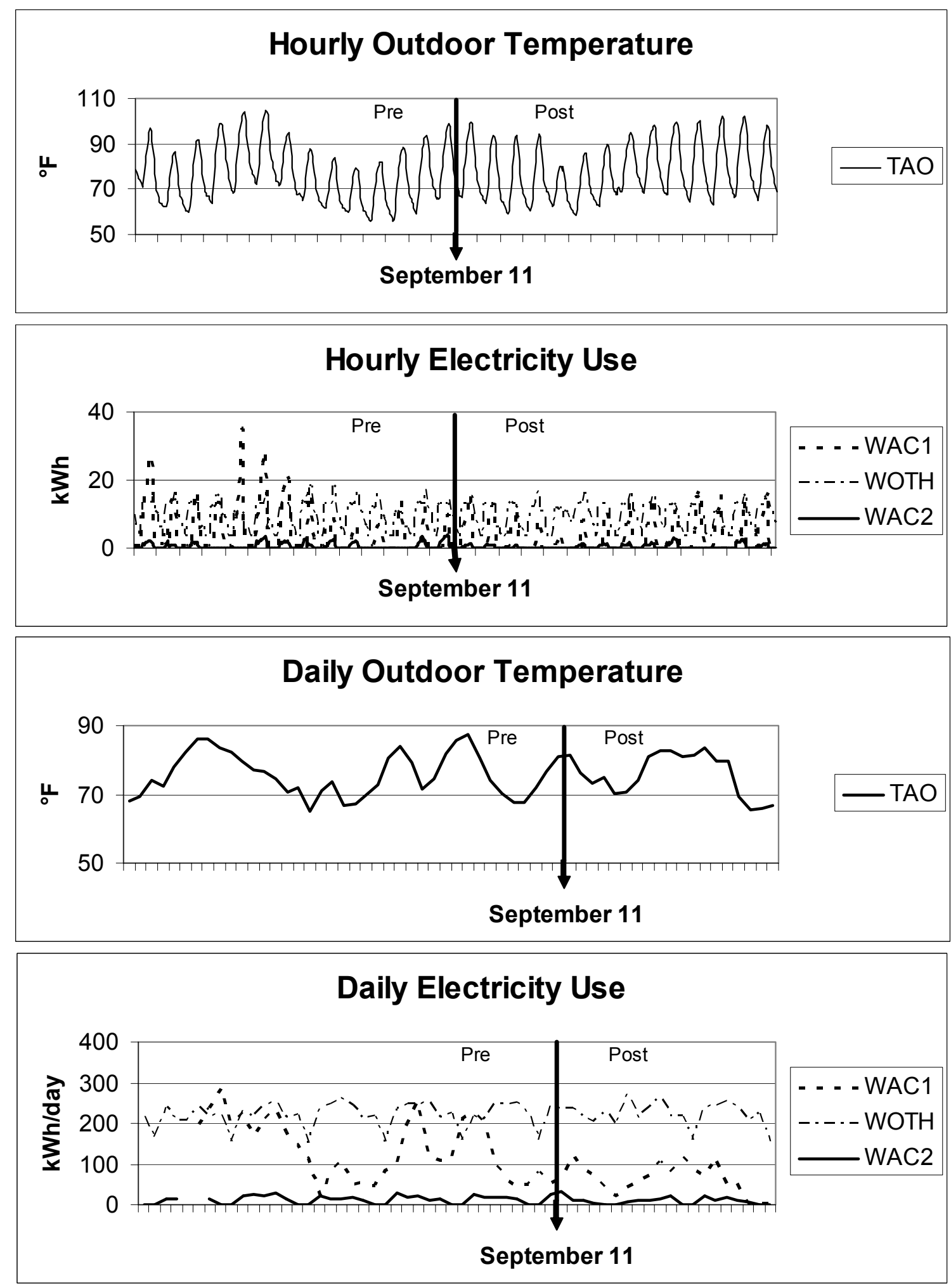

Figure 11. Carpeteria Flooring Center in Sacramento: Hourly and daily air conditioning energy uses. 'TAO' is the outdoor air temperature and 'WAC1', 'WAC2', and 'WOTH' are the electricity use for AC1, AC2, and "other" end uses. Time interval = day. 

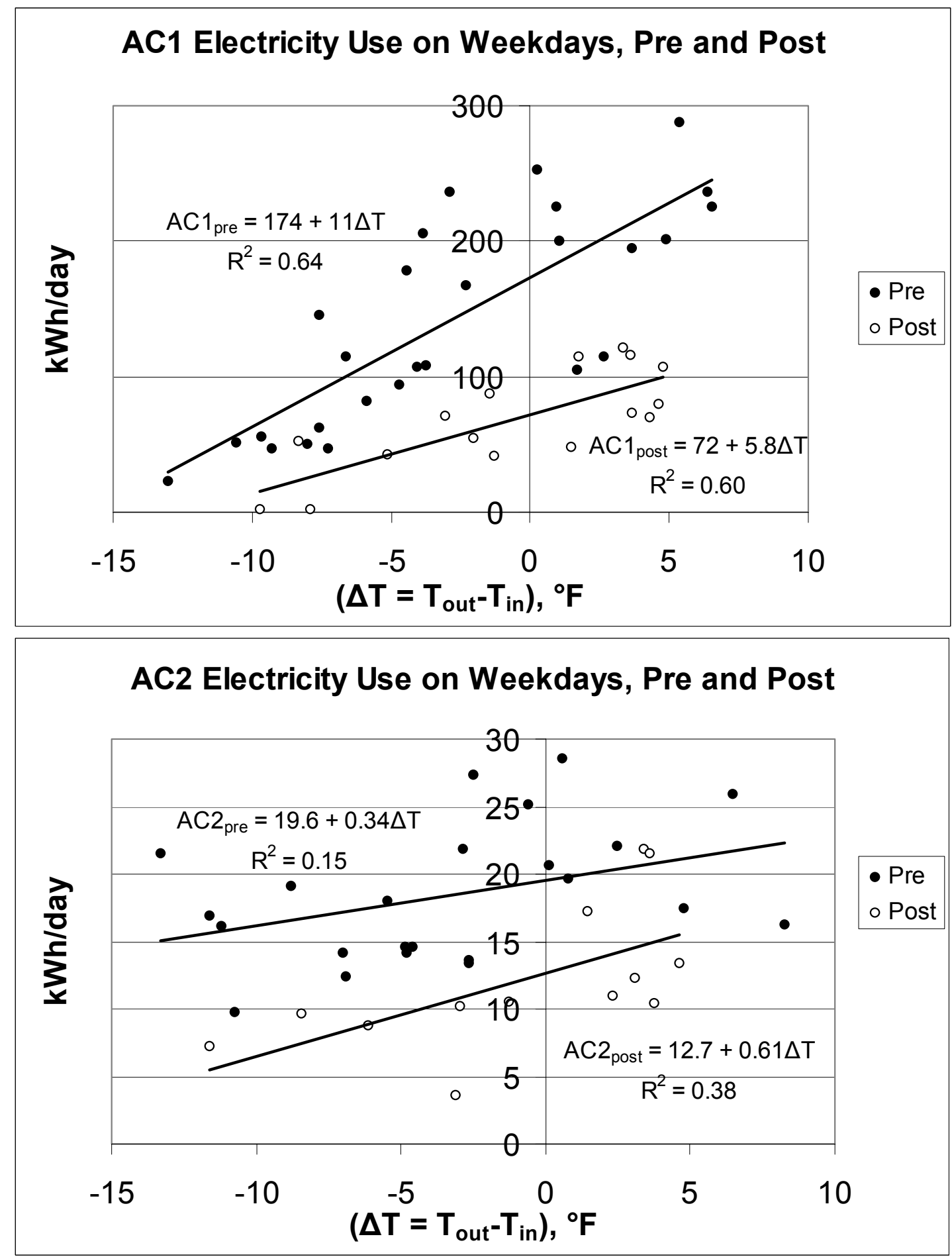

Figure 12. Carpeteria Flooring Center in Sacramento: Daily electricity uses for weekdays during Pre and Post periods for $\mathrm{AC} 1$ and $\mathrm{AC} 2$ as a function of daily outdoor and indoor temperature difference $\left(\triangle T=T_{\text {out }}-T_{\text {in }}\right)$. ' $A C 1$ ' and ' $A C 2$ ' are daily use for two air-conditioning systems. On a typical hot day when the daily average ambient temperature is about over $85^{\circ} \mathrm{F}$, daily savings are about $107 \mathrm{kWh}$. Daily savings increases about $5.3 \mathrm{kWh} /{ }^{\circ} \mathrm{F}$ for $\Delta \mathrm{T}$ above $-19^{\circ} \mathrm{F}$. 
Table 6. Carpeteria Flooring Center in Sacramento: Regression of air conditioner daily electricity use $\mathrm{E}(\mathrm{kWh})$ to temperature difference $\Delta \mathrm{T}=\mathrm{T}_{\text {out }}-\mathrm{T}_{\text {in }}\left({ }^{\circ} \mathrm{F}\right)$.

\begin{tabular}{|c|c|c|c|c|c|c|}
\hline \multirow[t]{2}{*}{ A/C System } & \multicolumn{3}{|l|}{ Pre } & \multicolumn{3}{|l|}{ Post } \\
\hline & $\mathrm{a}$ & b & $\mathrm{R}^{2}$ & a & $\mathrm{b}$ & $\mathrm{R}^{2}$ \\
\hline \multicolumn{7}{|l|}{$\mathrm{AC1}$} \\
\hline $\mathrm{E}=\mathrm{a}+\mathrm{b} \Delta \mathrm{T}$ & 173.7 & 11.05 & 0.64 & 72.0 & 5.77 & 0.60 \\
\hline \multicolumn{7}{|l|}{$\mathrm{AC2}$} \\
\hline $\mathrm{E}=\mathrm{a}+\mathrm{b} \Delta \mathrm{T}$ & 19.6 & 0.34 & 0.15 & 12.7 & 0.61 & 0.38 \\
\hline
\end{tabular}

Table 7. Carpeteria Flooring Center in Sacramento: Estimates of daily A/C electricity savings.

\begin{tabular}{|c|c|c|c|c|c|c|}
\hline \multirow[b]{2}{*}{ A/C System } & \multicolumn{3}{|c|}{ Pre: August 8 to September 10} & \multicolumn{3}{|c|}{ Post: September 11-30 } \\
\hline & $\begin{array}{l}\text { Base use } \\
(\mathrm{kWh} / \mathrm{d})\end{array}$ & $\begin{array}{l}\text { Savings } \\
(\mathrm{kWh} / \mathrm{d})\end{array}$ & $\begin{array}{l}\text { Savings } \\
(\%)\end{array}$ & $\begin{array}{l}\text { Base use } \\
(\mathrm{kWh} / \mathrm{d})\end{array}$ & $\begin{array}{l}\text { Savings } \\
(\mathrm{kWh} / \mathrm{d})\end{array}$ & $\begin{array}{l}\text { Savings } \\
(\%)\end{array}$ \\
\hline AC1 & & & & & & \\
\hline (a) Daily Average & 142 & 86 & 61 & 68 & 98 & 59 \\
\hline (b) $\Delta \mathrm{T}=7^{\circ} \mathrm{F}$ & 251 & 139 & 55 & 112 & 139 & 55 \\
\hline AC2 & & & & & & \\
\hline (a) Daily Average & 18.8 & 8.2 & 44 & 12.2 & 7.1 & 37 \\
\hline (b) $\Delta \mathrm{T}=7^{\circ} \mathrm{F}$ & 21.9 & 4.9 & 22 & 17.0 & 4.9 & 22 \\
\hline $\mathrm{AC} 1+\mathrm{AC} 2$ & & & & & & \\
\hline (a) Daily Average & 161 & 94 & 58 & 80 & 105 & 57 \\
\hline (b) $\Delta \mathrm{T}=7^{\circ} \mathrm{F}$ & 273 & 144 & 53 & 129 & 146 & 53 \\
\hline
\end{tabular}

Notes: "Pre" (August 8 to September 10, 2002) shows estimates of savings (a) average measured daily $A / C$ use and (b) projected $A / C$ use when $\Delta T=T_{\text {out }}-T_{\text {in }}=7^{\circ} \mathrm{F}$. "Post" shows analogous data for the period of September 11-30, 2002. 
Table 8. Carpeteria Flooring Center in Sacramento: Regression of AC1 air conditioner power demand $\mathrm{P}(\mathrm{kW})$ to outside air temperature $\mathrm{T}_{\text {out }}\left({ }^{\circ} \mathrm{F}\right)$ via relation $\mathrm{P}=\mathrm{a}+\mathrm{bT}$.

\begin{tabular}{|l|l|l|l|l|l|l|}
\hline \multirow{2}{*}{ Hour } & \multicolumn{2}{|l}{ Pre } & Post \\
\cline { 2 - 7 } & $\mathrm{a}$ & $\mathrm{b}$ & $\mathrm{R}^{2}$ & $\mathrm{a}$ & $\mathrm{b}$ & $\mathrm{R}^{2}$ \\
\hline 12 & -54.5 & 0.75 & 0.76 & -17.0 & 0.25 & 0.50 \\
\hline 13 & -51.2 & 0.70 & 0.56 & -22.6 & 0.32 & 0.58 \\
\hline 14 & -53.8 & 0.75 & 0.66 & -26.8 & 0.38 & 0.75 \\
\hline 15 & -58.5 & 0.82 & 0.73 & -25.4 & 0.36 & 0.60 \\
\hline 16 & -61.2 & 0.85 & 0.64 & -35.1 & 0.48 & 0.79 \\
\hline 17 & -57.5 & 0.82 & 0.67 & -34.3 & 0.48 & 0.78 \\
\hline Average & -56.1 & 0.78 & & -26.9 & 0.38 & \\
\hline
\end{tabular}

Notes: The average peak demand savings is about $13.1 \mathrm{~kW}$ when the outside temperature is $105^{\circ} \mathrm{F}$. The average peak demand savings increases by about $0.4 \mathrm{~kW} / \mathrm{F}$ for outdoor temperatures above $72.6^{\circ} \mathrm{F}$.

\section{Air Conditioning Peak Demand and Savings}

To estimate the effect of cool roofs on peak demand electricity use, we inspected the hourly AC1 data for hours 12 through 17 (see Figure 13). Figure 13 clearly depicts a substantial reduction in hourly A/C electricity use for all hours. The peak demand reductions are higher for higher outdoor temperature. We correlated the hourly AC1 electricity use with the hourly outdoor temperature; the correlation statistics are summarized in Table 8. The correlations indicate that the average (for hours 12-17) peak demand savings is about $13.1 \mathrm{~kW}$ when the outside temperature is $105^{\circ} \mathrm{F}\left(11 \mathrm{~kW}\right.$ for $\left.100^{\circ} \mathrm{F}\right)$. The average peak demand savings increases by about $0.4 \mathrm{~kW} /{ }^{\circ} \mathrm{F}$ for outdoor temperatures above $72.6^{\circ} \mathrm{F}$. On hot days, AC2 is approximately $9 \%$ of $\mathrm{AC} 1$ (see Table 7), hence the total peak demand savings for AC1+AC2 is estimated at $14.3 \mathrm{~kW}$ when the outside temperature is $105^{\circ} \mathrm{F}\left(12 \mathrm{~kW}\right.$ for $\left.100^{\circ} \mathrm{F}\right)$.

\section{Simulated Air Conditioning Energy Use and Savings}

\section{Building Description}

The detailed building characteristics data used for simulation of the Carpeteria Flooring Center are summarized in Table 9. The building is a 17,300 $\mathrm{ft}^{2}$ single-story of concrete tilt-up construction. The interior area consists of $8,760 \mathrm{ft}^{2}$ of high ceiling showroom, 1,720 $\mathrm{ft}^{2}$ of low ceiling showroom, 1,880 ft' of office space and 4,940 ft' $\mathrm{of}^{2}$ unconditioned warehouse space. The showroom is mostly open with $16^{\prime}$ high ceilings with a portion of dropped $10^{\prime} \mathrm{t}$-bar ceiling. The office is all t-bar or sheetrock ceiling and the warehouse is all open. The open areas are insulated with multi-layer radiant barrier [R-7]. The t-bar ceiling has 10" of fiberglass batt insulation [R38] on top of the ceiling and no insulation at the roof. 
The roof was installed in 1989 and consists of a plywood deck covered with a gray mineral capsheet in very poor condition and a reflectance of $21 \%$ as shown in Figure 3e. After coating the roof with a white elastomeric paint the reflectance increased to $83 \%$ as shown in Figure $3 \mathrm{f}$. The thermal emittance of these materials is 0.9 .

The operating schedule and the non-AC electricity use of the building was identified from the $\mathrm{AC} 1, \mathrm{AC} 2$ and OTH kW channels averaged daily by hour as shown in Figure 11. The retail store was in operation from $8 \mathrm{am}-7 \mathrm{pm}$ weekdays and weekends, but the office did not operate on Sundays. The daytime peak non-AC power demand was about $13 \mathrm{~kW}$ or $0.75 \mathrm{~W} / \mathrm{ft}^{2}$.

The building is conditioned with 6 rooftop packaged constant volume cooling and gas heating units (five 5-ton units for the showroom and one 3-ton unit for the office). The operating Energy Efficiency Ratio (EER) of the cooling equipment were calculated from the monitored AC1 (showroom) and AC2 (office) kW channels and nameplate capacity as 8.5 and 10.3, respectively. 

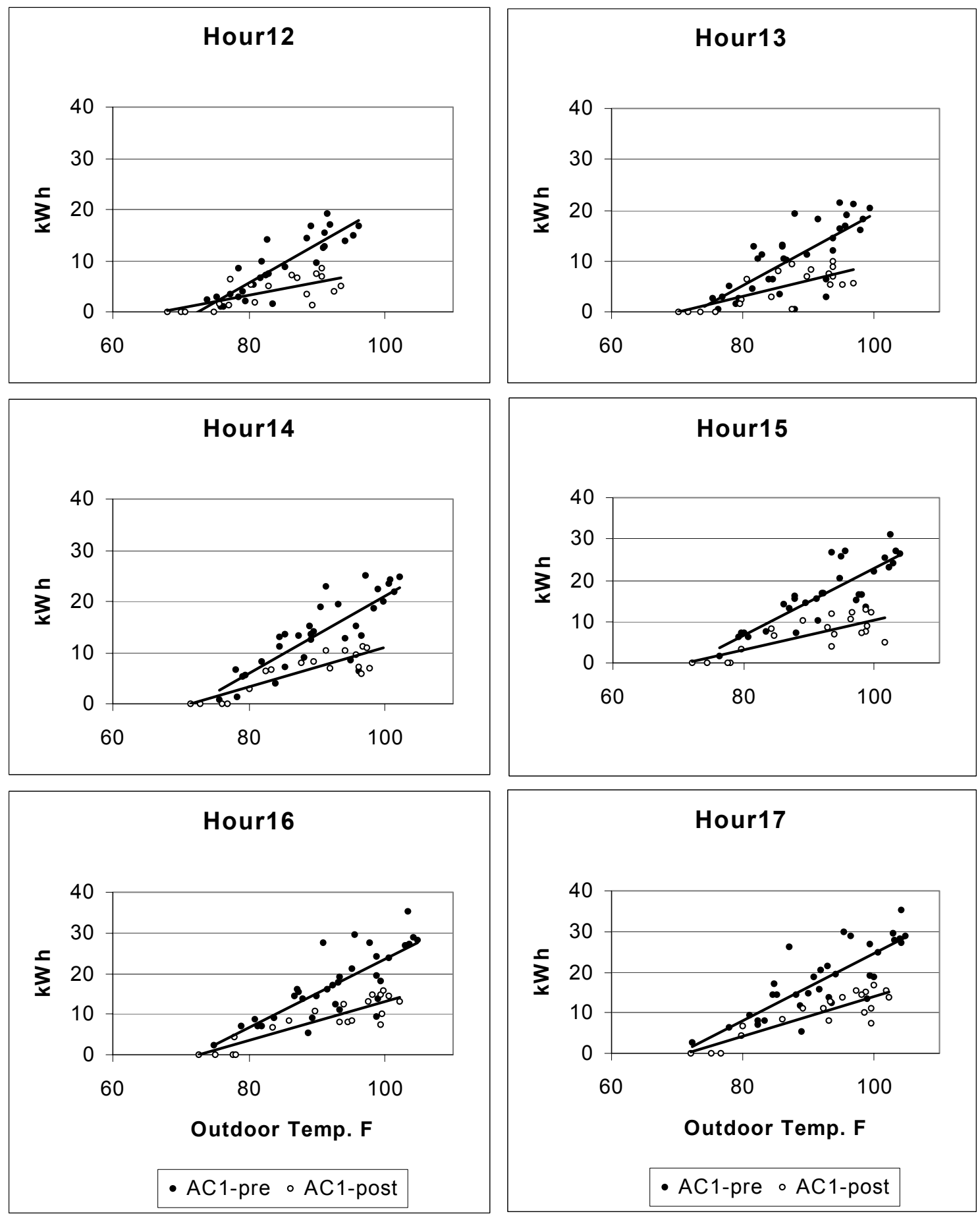

Figure 13. Carpeteria Flooring Center in Sacramento: Hourly electrical demand during Pre and Post periods as a function of outdoor temperature for AC1. 
Table 9. Carpeteria Flooring Center in Sacramento: Building description.

\begin{tabular}{|c|c|c|}
\hline \multicolumn{3}{|l|}{ General } \\
\hline & Single-Story Retail Store & $17298 \mathrm{ft}^{2}$ \\
\hline & Conditioned Floor Area & $12,362 \mathrm{ft}^{2}$ \\
\hline & Orientation & $\mathrm{N}\left(0^{\circ}\right)$ \\
\hline & North & $142.5^{\prime}$ \\
\hline & East & $146^{\prime}$ \\
\hline & Southeast & $45^{\prime}$ \\
\hline & Southwest & $199^{\prime}$ \\
\hline & Northwest & $22.5^{\prime}$ \\
\hline & Location & Sacramento, N. CA \\
\hline & Weather Site & CTZ12 \\
\hline \multicolumn{3}{|l|}{ Zones } \\
\hline & Showroom [High] & $8764 \mathrm{ft}^{2}\left[16^{\prime}\right]$ \\
\hline & Showroom [Low] & $1716 \mathrm{ft}^{2}\left[10^{\prime}\right]$ \\
\hline & Office & $1882 \mathrm{ft}^{2}\left[10^{\prime}\right]$ \\
\hline & Warehouse [Unconditioned] & $4936 \mathrm{ft}^{2}\left[16^{\prime}\right]$ \\
\hline \multicolumn{3}{|c|}{ Roof Construction } \\
\hline & Built-Up W/ Grey Mineral Capsheet & Pre-retrofit \\
\hline & Built-Up W/ White Elastomeric Coating & Post-retrofit \\
\hline & Wood Deck & Low-slope \\
\hline & Office And Showroom [Low] & \\
\hline & Plenum & \\
\hline & 10" Fiberglass Batt Insulation [R-38] & \\
\hline & $\begin{array}{l}\text { Dropped T-Bar Ceiling With } 3 / 4 \text { " Acoustical } \\
\text { Tile }\end{array}$ & \\
\hline & Warehouse And Showroom [High] & \\
\hline & Multi-Layer Radiant Barrier & $\mathrm{R}-7$ \\
\hline \multicolumn{3}{|c|}{ Roof Solar Reflectance } \\
\hline & Pre-Retrofit & 0.21 \\
\hline
\end{tabular}




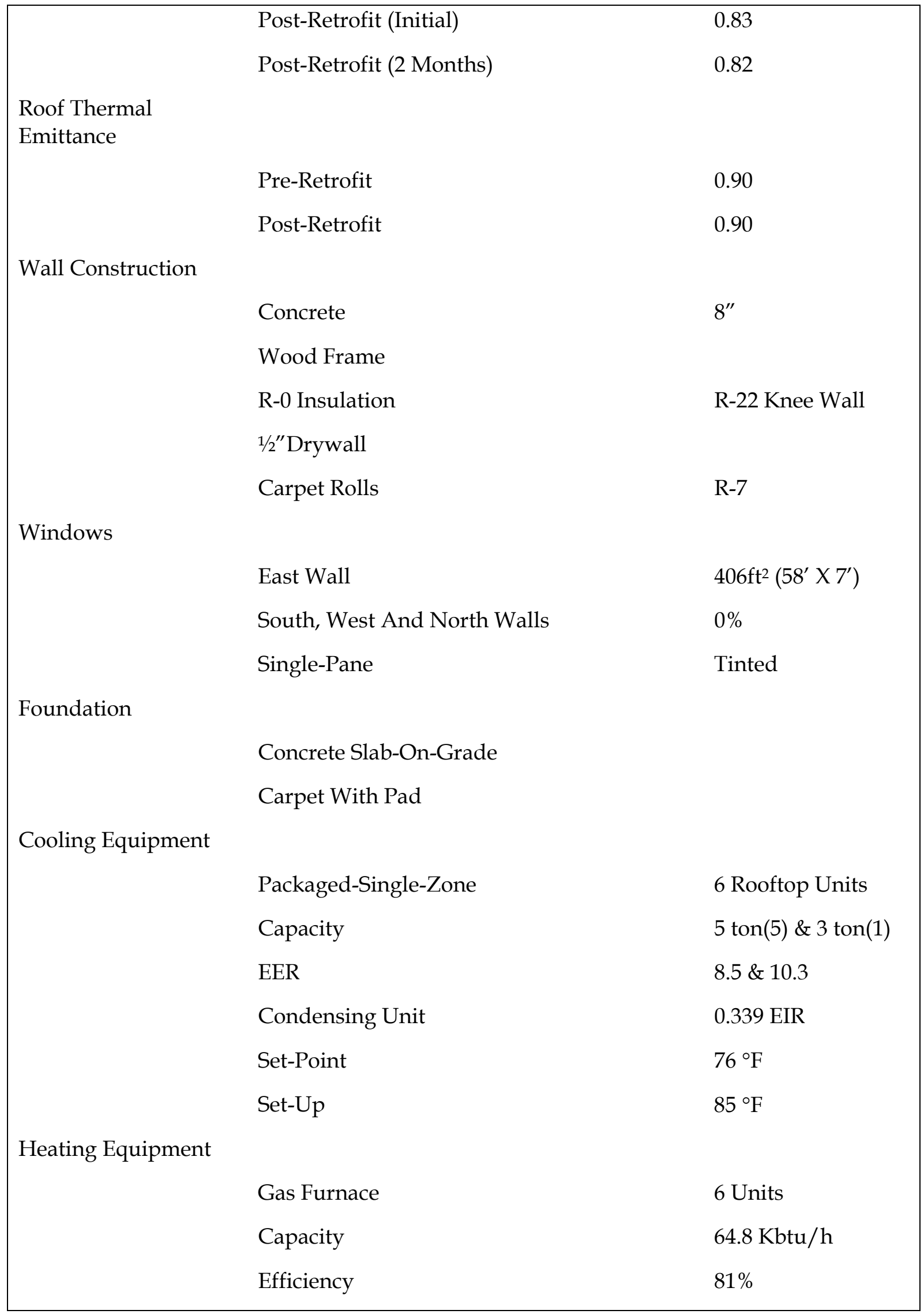




$\begin{array}{ll}\text { Set-Point } & 70^{\circ} \mathrm{F} \\ \text { Set-Back } & 55^{\circ} \mathrm{F}\end{array}$

Distribution

Constant-Volume Forced Air System 6 Units

Capacity $2000 \& 1200 \mathrm{cfm}$

Fan Coil Unit $\quad 0.545 \mathrm{~W} / \mathrm{cfm}$

Economizer Fixed

Duct Leakage $\quad 20 \%$

Duct Temperature Increase $\quad 3{ }^{\circ} \mathrm{F}$

Outside Air $15 \mathrm{cfm} /$ Person

Schedule

Operating Hours

Showroom/Warehouse $\quad 8 a m-7 p m$

(Weekday/Weekend)

Office (Weekday/Saturday) 8am -7pm

Interior Load

Infiltration Air $\quad 0.5 \mathrm{ACH}$

Lighting \& Plug Use $\quad 0.75 \mathrm{~W} / \mathrm{ft}^{2}$

Occupants 40 


\section{Calibrated Simulations}

Annual cooling and heating energy use and peak power demand were simulated on an hourly time step with the DOE-2.1E building energy simulation program (BESG, 1990 and 1993) using California CTZ weather data for climate zone 12 (see Figure 1; Sacramento is located in California climate zone 12) and for dark and cool roof scenarios. In DOE-2 the ABSORPTANCE keyword for roof construction was 0.79 for the dark roof and 0.17 for the cool roof. In these simulations, we used both the measured daily and hourly data to calibrate the simulations. We used measured outdoor temperature to adjust the simulated cooling energy use that was based on the CTZ weather data. We were able to calibrate the simulated average daily energy use data within about $2 \%$ of the measured cooling energy use. Our effort to calibrate simulated hourly air conditioning electricity use was not as successful. The summary results for these calibrated simulations are presented in Table 10.

Table 10. Carpeteria Flooring Center in Sacramento: Simulated cooling electricity savings and adjustment factors. $^{a}$

\begin{tabular}{|l|c|c|c|c|}
\hline Period & $\begin{array}{c}\text { Measured average } \\
\text { temperature }\left({ }^{\circ} \mathrm{F}\right)\end{array}$ & $\begin{array}{c}\text { Simulated } \\
\text { Savings }\end{array}$ & $\begin{array}{c}\text { Measured } \\
\text { Savings }\end{array}$ & $\begin{array}{c}\text { Adjustment } \\
\text { Factor }\end{array}$ \\
\hline Hour 12 & 83.0 & $7.0 \mathrm{~kW}$ & $4.0 \mathrm{~kW}$ & 0.57 \\
\hline Hour 13 & 86.8 & $7.6 \mathrm{~kW}$ & $4.8 \mathrm{~kW}$ & 0.64 \\
\hline Hour 14 & 89.6 & $7.9 \mathrm{~kW}$ & $6.2 \mathrm{~kW}$ & 0.79 \\
\hline Hour 15 & 91.5 & $7.8 \mathrm{~kW}$ & $8.8 \mathrm{~kW}$ & 1.12 \\
\hline Hour 16 & 92.1 & $7.4 \mathrm{~kW}$ & $7.6 \mathrm{~kW}$ & 1.02 \\
\hline Hour 17 & 91.7 & $6.6 \mathrm{~kW}$ & $7.9 \mathrm{~kW}$ & 1.19 \\
\hline Average hours 12-17 & 89.1 & $7.4 \mathrm{~kW}$ & $6.7 \mathrm{~kW}$ & 0.90 \\
\hline Hour when $\mathrm{T}_{\text {out }}=105^{\circ} \mathrm{F}$ & 105 & $8.7 \mathrm{~kW}$ & $13.1 \mathrm{~kW}$ & 1.50 \\
\hline $\begin{array}{l}\text { Average daily energy } \\
\text { savings }\end{array}$ & 76.1 & $82.1 \mathrm{kWh}$ & $84.0 \mathrm{kWh}$ & 1.02 \\
\hline
\end{tabular}

\section{Notes:}

a. The simulated average daily savings is $82 \mathrm{kWh}$ (compared to measured savings of $84 \mathrm{kWh}$ ). The simulated average peak demand savings for hour 12-17 is $7.4 \mathrm{~kW}$ (compared to measured savings of $6.7 \mathrm{~kW}$ ). The simulated average peak demand savings is $8.7 \mathrm{~kW}$ (compared to measured savings of $13.1 \mathrm{~kW}$ ) when the outside temperature is $105^{\circ} \mathrm{F}$. The adjustment factors are the ratio of measured to simulated values.

b. Daily energy savings averaged over the monitoring period (Pre and Post). 
Table 10 shows the simulated cooling electricity savings and compares them with measured savings data. The simulated average daily savings is $82 \mathrm{kWh}$ as compared to the measured savings of $84 \mathrm{kWh}$ (a difference of about -2\%). The table also shows the simulated hourly peak demand savings and compares them with the corresponding measured data. The hourly simulated peak demand data are from $-16 \%$ to $+75 \%$ different from the measured data. The simulated average peak demand savings for hour $12-17$ is $7.4 \mathrm{~kW}$ compared to measured savings of $6.7 \mathrm{~kW}$ (a difference of $+10 \%$ ). The simulated average peak demand savings is $8.7 \mathrm{~kW}$ compared to measured savings of $13.1 \mathrm{~kW}$ when the outside temperature is $105^{\circ} \mathrm{F}$ (a difference of $-34 \%)$. We defined adjustment factors as the ratio of measured to simulated values. These adjustment factors will be used to adjust the simulated savings for other California climate zones.

\section{Estimated Savings for Other California Climate Zones}

We used the calibrated DOE-2 model to simulate the energy use for other climate regions, using California CTZ weather data in each of the 16 climate zones (see Figure 1) and for dark and cool roof scenarios. All input variables were kept constant as the calibrated model. Table 11 summarizes the results of these simulations. All savings estimates are normalized per $1000 \mathrm{ft}^{2}$ of conditioned roof area. The simulated savings are scaled using the adjustment factor of 1.02 as shown in Table 10.

HVAC systems are typically designed based on peak cooling load. A lower cooling load from the installation of cool roofs results in a smaller air-handling system that operates more efficiently throughout both cooling and heat seasons. The estimated savings are presented for the two cases of "same HVAC system" and "optimal HVAC system." "Same HVAC" savings refer to cool roofs savings with the same-size air conditioners for both cool and hot roofs. This savings apply to retrofit application of cool roofs on existing buildings. "Optimal HVAC" savings refer to cool roofs savings where the air conditioners are optimally sized for cool and hot roofs. This savings apply to design of new buildings or a major retrofit application where cool roofs are installed and HVAC systems are sized accordingly.

Table 11 shows that in a retrofit application in climate zones 2 and 4-16, installing a cool roof on a similar building as Carpeteria Flooring Center can save about 500-1400 kWh per year per 1000 $\mathrm{ft}^{2}$ of conditioned roof area. In a new building, the estimated savings are 900-2000 $\mathrm{kWh}$ per year per $1000 \mathrm{ft}^{2}$ of conditioned roof area. The annual savings in climate zones 1 and 3 for retrofit and new applications are less than $500 \mathrm{kWh}$ and $600 \mathrm{kWh}$, respectively.

Table 12 shows the estimates of peak demand savings for all 16 climate zones. The savings are estimated for an average hour between hours 12 to 17 and for the period of June 1 to September 30. For the average condition in a retrofit application the estimated peak demand savings are about $0.27-0.54 \mathrm{~W} / \mathrm{ft}^{2}$, in climate zones $2-16$. For a retrofit application in which air-conditioners can be downsized, the estimated savings are about $0.31-0.63 \mathrm{~W} / \mathrm{ft}^{2}$. During extreme summer peak conditions, the estimated peak demand savings can reach $1.0 \mathrm{~W} / \mathrm{ft}^{2}$.

Assuming an average cost of $\$ 0.10 / \mathrm{kWh}$, in all climate zones (but Zone 1 and 3 ), in a retrofit application, the estimates of energy savings range from $0.05-0.14 \$ / \mathrm{ft}^{2}\left(0.5-1.4 \$ / \mathrm{m}^{2}\right)$. The average summertime peak-demand savings ranges from 0.27 to $0.54 \mathrm{~W} / \mathrm{ft}^{2}$. Assuming a monthly peak-demand charge of $\$ 20 / \mathrm{kW}$, the estimated May-October peak-demand savings is [6 month]x[\$20/kW/month]x[0.27-0.54 W/ft²]x[1/1000 kW/W] = 0.03-0.06 \$/ $\mathrm{ft}^{2}(0.32-0.64$ 
$\$ / \mathrm{m}^{2}$ ). The total annual savings (energy plus peak demand reduction) ranges from 0.08 to 0.20 $\$ / \mathrm{ft}^{2}\left(0.8\right.$ to $\left.2.0 \$ / \mathrm{m}^{2}\right)$.

Table 11. Carpeteria Flooring Center in Sacramento: Estimated annual energy savings of buildings with similar characteristics in other California Climate Zones.

\begin{tabular}{|c|c|c|c|c|c|c|c|c|c|}
\hline \multirow[t]{3}{*}{ CTZ } & \multirow{3}{*}{$\begin{array}{l}\text { Base use } \\
\text { (kWh/year) }\end{array}$} & \multicolumn{4}{|c|}{ Same HVAC } & \multicolumn{4}{|c|}{ Optimal HVAC } \\
\hline & & \multicolumn{2}{|c|}{$\begin{array}{l}\text { Simulated } \\
\text { savings }\end{array}$} & \multicolumn{2}{|c|}{$\begin{array}{l}\text { Adjusted } \\
\text { savings }\end{array}$} & \multicolumn{2}{|c|}{$\begin{array}{c}\text { Simulated } \\
\text { savings }\end{array}$} & \multicolumn{2}{|c|}{ Adjusted savings } \\
\hline & & (kWh) & $\%$ & $(\mathrm{kWh})$ & $\%$ & $(\mathrm{kWh})$ & $\%$ & $(\mathrm{kWh})$ & $\%$ \\
\hline 1 & 960 & 60 & 6.3 & 61 & 6.4 & 143 & 14.9 & 146 & 15.2 \\
\hline 2 & 3976 & 1047 & 26.3 & 1068 & 26.9 & 1502 & 37.8 & 1532 & 38.5 \\
\hline 3 & 1533 & 366 & 23.9 & 373 & 24.3 & 599 & 39.1 & 611 & 39.9 \\
\hline 4 & 3011 & 965 & 32.0 & 984 & 32.7 & 1514 & 50.3 & 1544 & 51.3 \\
\hline 5 & 2278 & 534 & 23.4 & 545 & 23.9 & 920 & 40.4 & 938 & 41.2 \\
\hline 6 & 3177 & 1019 & 32.1 & 1040 & 32.7 & 1466 & 46.1 & 1495 & 47.1 \\
\hline 7 & 3088 & 884 & 28.6 & 902 & 29.2 & 1170 & 37.9 & 1193 & 38.6 \\
\hline 8 & 3428 & 1153 & 33.6 & 1176 & 34.3 & 1649 & 48.1 & 1682 & 49.1 \\
\hline 9 & 3627 & 1078 & 29.7 & 1099 & 30.3 & 1533 & 42.3 & 1564 & 43.1 \\
\hline 10 & 4740 & 1394 & 29.4 & 1422 & 30.0 & 2000 & 42.2 & 2040 & 43.0 \\
\hline 11 & 5284 & 979 & 18.5 & 998 & 18.9 & 1407 & 26.6 & 1436 & 27.2 \\
\hline 12 & 3965 & 976 & 24.6 & 996 & 25.1 & 1416 & 35.7 & 1445 & 36.4 \\
\hline 13 & 5179 & 1262 & 24.4 & 1288 & 24.9 & 1753 & 33.8 & 1788 & 34.5 \\
\hline 14 & 6669 & 1271 & 19.1 & 1296 & 19.4 & 1562 & 23.4 & 1593 & 23.9 \\
\hline 15 & 8854 & 1494 & 16.9 & 1524 & 17.2 & 1872 & 21.1 & 1909 & 21.6 \\
\hline 16 & 2705 & 608 & 22.5 & 620 & 22.9 & 999 & 36.9 & 1019 & 37.7 \\
\hline
\end{tabular}

Notes: All estimates are normalized per $1000 \mathrm{ft}^{2}$ of conditioned roof area. "Same HVAC" savings refer to cool roofs savings with the same-size air conditioners for both cool and hot roofs. "Optimal HVAC" savings refer to cool roofs savings where the air conditioners are separately sized for cool and hot roofs. HVAC systems are typically designed based on peak cooling load. A lower cooling load results in a smaller air-handling system that operates more efficiently throughout both cooling and heat seasons. 
Table 12. Carpeteria Flooring Center in Sacramento: Estimated peak demand savings of buildings with similar characteristics in other California Climate Zones.

\begin{tabular}{|c|c|c|c|c|}
\hline \multirow{2}{*}{ CTZ } & \multicolumn{2}{|c|}{ Simulated Savings $\left(\mathrm{W} / \mathrm{ft}^{2}\right)$} & \multicolumn{2}{c|}{ Adjusted Savings $\left(\mathrm{W} / \mathrm{ft}^{2}\right)$} \\
\cline { 2 - 5 } & Same HVAC & Optimal HVAC & Same HVAC & Optimal HVAC \\
\hline 1 & 0.06 & 0.08 & 0.06 & 0.07 \\
\hline 2 & 0.51 & 0.60 & 0.46 & 0.54 \\
\hline 3 & 0.30 & 0.34 & 0.27 & 0.31 \\
\hline 4 & 0.48 & 0.59 & 0.43 & 0.53 \\
\hline 5 & 0.35 & 0.46 & 0.32 & 0.42 \\
\hline 6 & 0.44 & 0.53 & 0.40 & 0.48 \\
\hline 7 & 0.36 & 0.42 & 0.33 & 0.38 \\
\hline 8 & 0.48 & 0.57 & 0.43 & 0.52 \\
\hline 9 & 0.45 & 0.54 & 0.40 & 0.48 \\
\hline 10 & 0.56 & 0.68 & 0.50 & 0.61 \\
\hline 11 & 0.49 & 0.58 & 0.45 & 0.52 \\
\hline 12 & 0.51 & 0.60 & 0.46 & 0.54 \\
\hline 13 & 0.59 & 0.69 & 0.54 & 0.63 \\
\hline 14 & 0.54 & 0.60 & 0.49 & 0.54 \\
\hline 15 & 0.56 & 0.62 & 0.51 & 0.56 \\
\hline 16 & 0.41 & 0.48 & 0.37 & 0.44 \\
\hline
\end{tabular}

Notes: The peak demand savings are average estimates for hours 12-17 from June 1 to September 30. All estimates are normalized per ft ${ }^{2}$ of conditioned roof area. "Same HVAC" savings refer to cool roofs savings with the same-size air conditioners for both cool and hot roofs. "Optimal HVAC" savings refer to cool roofs savings where the air conditioners are separately sized for cool and hot roofs. 


\subsubsection{School Building in San Marcos}

\subsubsection{Building Description}

Richland Elementary School, located in San Marcos, 30 miles north of San Diego, was selected as the Southern California school monitoring site. Building \#2, the largest of the 5 permanent classroom buildings, was instrumented. The building is a 6,200 $\mathrm{ft}^{2}$ single-story wood frame structure containing three classrooms, a library, and a computer laboratory (see Figure 14). The building has exterior hallways and extensive single glazing facing northeast. Rooms are conditioned by split systems with wall mounted condensing units and fan coils in the ceiling plenum. In addition there is a roof-mounted heat pump that conditions the telco closet. The roof was initially covered with a gray mineral cap sheet and is insulated with 8 " fiberglass batt attached to the underside of the roof sheathing. In 2000 the building was extensively remodeled with new lighting, new ceiling insulation, a dropped ceiling, and new fan coils (the old condensing units were retained). A "Sarnafil" white PVC single-ply membrane roof was installed at the end of July, 2002.

\subsubsection{Instrumentation and Data Acquisition Systems}

Monitoring data were collected for two months before and after installation of the reflective roof. Parameters measured to assess cool roof performance included:

- Roof surface temperatures

- Roof underside temperatures

- Indoor and plenum air temperatures

- Weather conditions

- Building energy use.

Table 13 summarizes the monitoring points and Figure 15 shows their locations.

After all sensors were installed they were calibrated using the following equipment:

Air temperatures: Visala HMI41 thermohygrometer

Relative humidity: Visala HMI41 thermohygrometer

Surface temperature: Raytek ST20 infrared thermometer

Electric power: $\quad$ Tif 2000A Wattprobe

In addition to the continuously monitored data, detailed one-time measurements and observations were performed.

Measurements of the roof albedo for the old mineral capsheet and the new membrane were measured using ASTM E1918 - Standard Test Method for Measuring Solar Reflectance of Horizontal and Low-Sloped Surfaces in the Field (ASTM 1997). Results are summarized in Table 14 and views of the old and new roof are shown in Figure 16. 


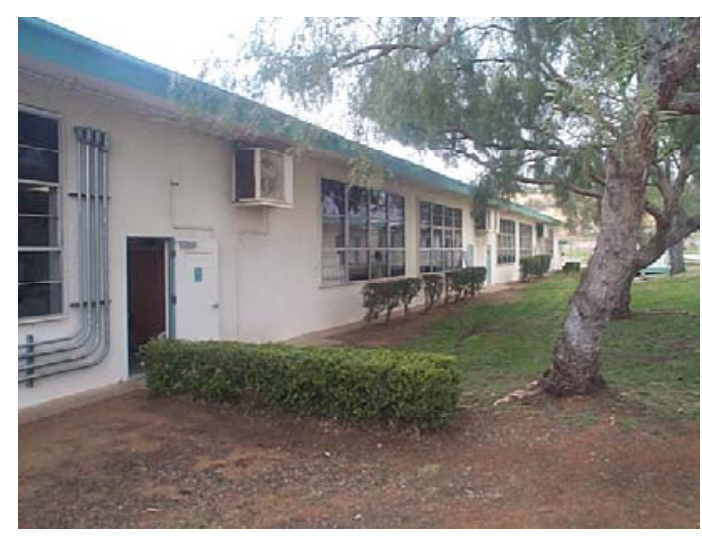

(a)

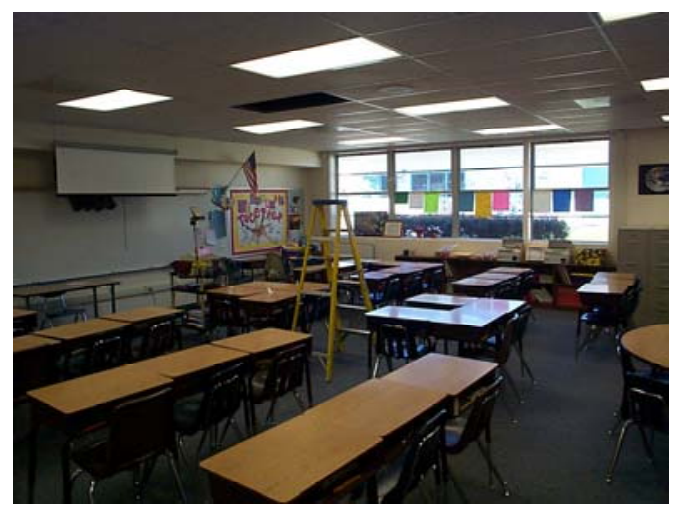

(c)

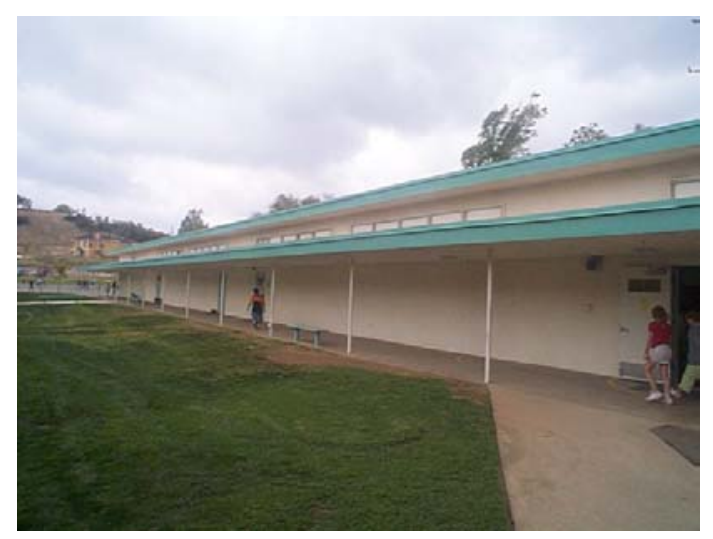

(b)

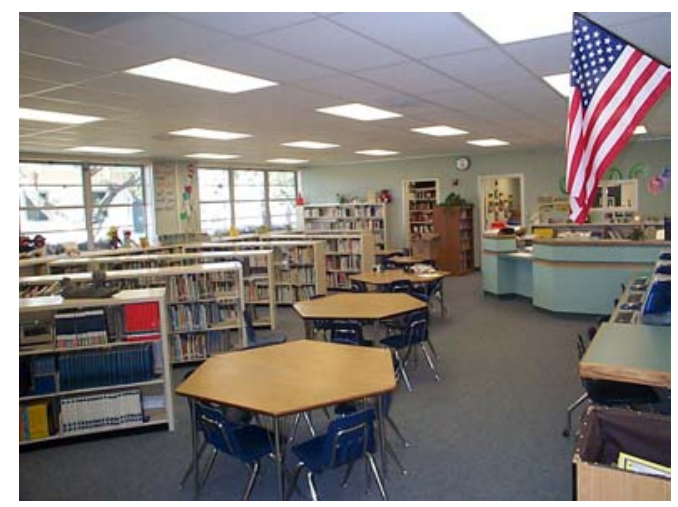

(d)

Figure 14. Richland Elementary School in San Marcos: (a) building \#2 NE elevation; (b) building \#2 SW elevation; (c) classroom 2-05; and (d) library. 
Table 13. Richland Elementary School in San Marcos: Building monitoring points.

\begin{tabular}{l|lll}
\hline No. & Name & Purpose & Location \\
\hline 1 & TRS-A & Roof surface temperature & Roof above room 2-05 \\
2 & TRS-B & Roof surface temperature & Roof above library \\
3 & TRU-A & Roof underside temperature & Plenum in room 2-05 \\
4 & TRU-B & Roof underside temperature & Plenum in library \\
3 & TAP-A & Plenum air temperature & Plenum in room 2-05 \\
4 & TAP-B & Plenum air temperature & Plenum in library \\
6 & TAI-A & Interior air temperature & Room 2-05 \\
6 & TAI-B & Interior air temperature & Library \\
6 & TAI-C & Interior air temperature & Computer lab \\
7 & TAO & Outdoor dry bulb temperature & Weather tower on building \#3 \\
8 & RHO & Outdoor relative humidity & Weather tower on building \#3 \\
11 & HSOL & Total horizontal insolation & Weather tower on building \#3 \\
12 & WAC1 & CU203, 205, 207 & Panel 2A \\
13 & WAC2 & CU204, 206, HP201 & Panel 2A\&2B \\
14 & WAC3 & CU201, CU202 & Panel 2B \\
15 & WPB & Total computer lab power & Panel 2B \\
16 & WTOT & Total building power & Panel 2A \\
\hline
\end{tabular}




Boys

Figure 15. Richland Elementary School in San Marcos: Building monitoring point locations. 
Table 14. Richland Elementary School in San Marcos: Roof albedo measurements.

\begin{tabular}{|c|c|c|c|c|c|c|}
\hline \multirow[b]{2}{*}{ Location } & \multirow[b]{2}{*}{ Notes } & & \multicolumn{3}{|c|}{ Measurement } & \multirow[b]{2}{*}{ Average } \\
\hline & & & 1 & 2 & 3 & \\
\hline \multicolumn{7}{|l|}{ Pre } \\
\hline \multirow[t]{3}{*}{1} & \multirow{3}{*}{$\begin{array}{l}\text { 5/22/2002 1:20 } \\
\text { Clear }\end{array}$} & $U p\left(\mathrm{~W} / \mathrm{m}^{2}\right)$ & 626 & 626 & 630 & 627 \\
\hline & & Down $\left(\mathrm{W} / \mathrm{m}^{2}\right)$ & 154 & 155 & 155 & 155 \\
\hline & & Albedo & $25 \%$ & $25 \%$ & $25 \%$ & $25 \%$ \\
\hline \multirow[t]{3}{*}{2} & & $U p\left(\mathrm{~W} / \mathrm{m}^{2}\right)$ & 622 & 593 & 590 & 602 \\
\hline & & Down $\left(\mathrm{W} / \mathrm{m}^{2}\right)$ & 155 & 149 & 148 & 151 \\
\hline & & Albedo & $25 \%$ & $25 \%$ & $25 \%$ & $25 \%$ \\
\hline \multicolumn{7}{|l|}{ Post } \\
\hline \multirow[t]{3}{*}{1} & \multirow{3}{*}{$\begin{array}{l}\text { 7/31/02 2:15 } \\
\text { High haze, breezy }\end{array}$} & $U p\left(\mathrm{~W} / \mathrm{m}^{2}\right)$ & 809 & 820 & 837 & 822 \\
\hline & & Down $\left(\mathrm{W} / \mathrm{m}^{2}\right)$ & 636 & 657 & 650 & 648 \\
\hline & & Albedo & $79 \%$ & $80 \%$ & $78 \%$ & $79 \%$ \\
\hline \multirow[t]{3}{*}{2} & & $U p\left(\mathrm{~W} / \mathrm{m}^{2}\right)$ & 818 & 821 & 799 & 813 \\
\hline & & Down $\left(\mathrm{W} / \mathrm{m}^{2}\right)$ & 648 & 644 & 625 & 639 \\
\hline & & Albedo & $79 \%$ & $78 \%$ & $78 \%$ & $79 \%$ \\
\hline \multicolumn{7}{|c|}{ Decommission } \\
\hline \multirow[t]{3}{*}{1} & \multirow{3}{*}{$\begin{array}{l}\text { 3/17/04 2:40pm } \\
\text { Clear, Breezy } \\
\text { Thin coating of brown dust }\end{array}$} & $U p\left(\mathrm{~W} / \mathrm{m}^{2}\right)$ & 612 & 611 & 607 & 610 \\
\hline & & Down $\left(\mathrm{W} / \mathrm{m}^{2}\right)$ & 360 & 359 & 357 & 359 \\
\hline & & Albedo & $59 \%$ & $59 \%$ & $59 \%$ & $59 \%$ \\
\hline \multirow[t]{3}{*}{2} & & $U p\left(\mathrm{~W} / \mathrm{m}^{2}\right)$ & 603 & 598 & 597 & 599 \\
\hline & & Down $\left(\mathrm{W} / \mathrm{m}^{2}\right)$ & 360 & 360 & 359 & 360 \\
\hline & & Albedo & $60 \%$ & $60 \%$ & $60 \%$ & $60 \%$ \\
\hline \multirow[t]{3}{*}{3} & \multirow[t]{3}{*}{ \#2 cleaned } & $U p\left(\mathrm{~W} / \mathrm{m}^{2}\right)$ & 593 & 589 & 586 & 589 \\
\hline & & Down $\left(\mathrm{W} / \mathrm{m}^{2}\right)$ & 400 & 397 & 395 & 397 \\
\hline & & Albedo & $67 \%$ & $67 \%$ & $67 \%$ & $67 \%$ \\
\hline
\end{tabular}




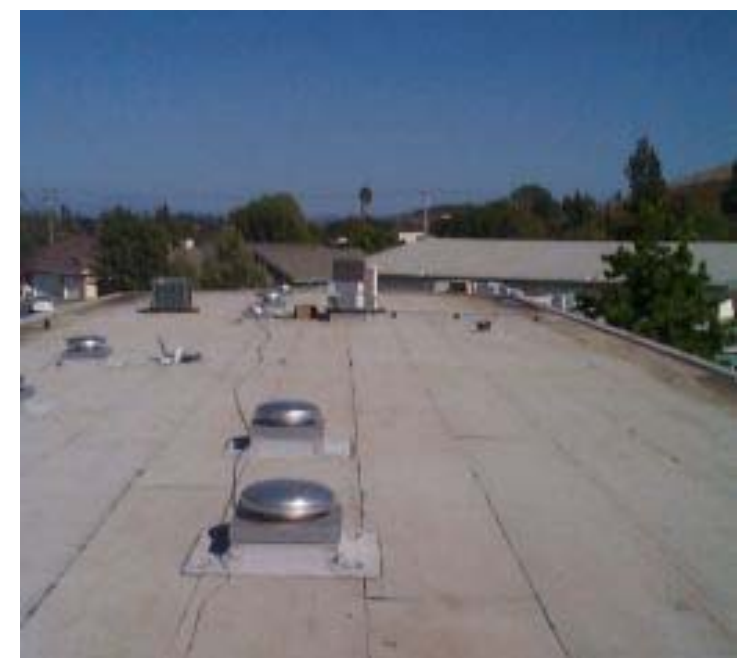

(a)

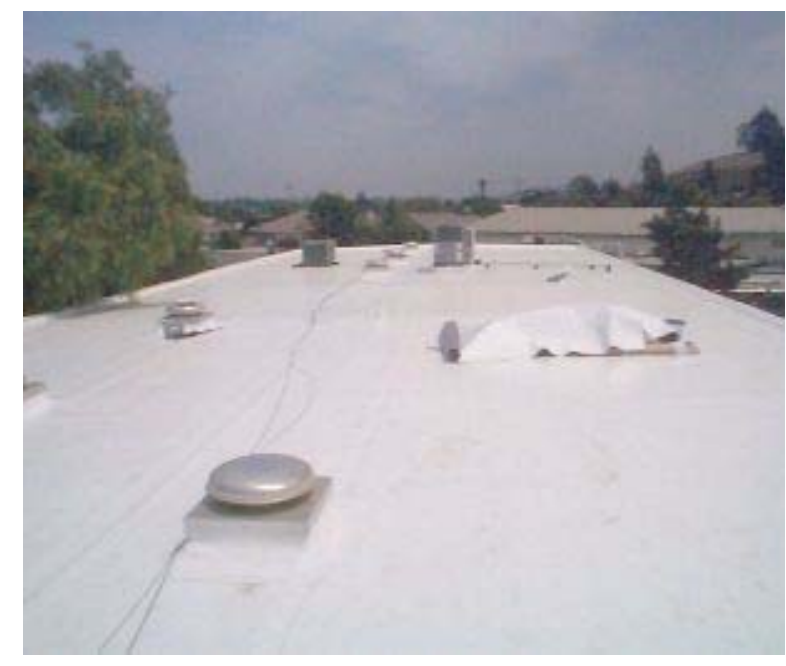

(b)

Figure 16. Richland Elementary School in San Marcos: (a) old mineral cap sheet, and (b) new roof membrane.

\subsubsection{Air Conditioning Systems and Building Operation Schedules}

\section{Air Conditioning Systems}

Each room in the building except for the bathrooms and telco room is conditioned by one or more 4-ton split system air conditioners (see 
Table 15.) All indoor units are RADCO FB4ANF048 fan coils with a $3 / 4$ hp fan and supply 1600 $\mathrm{cfm}$. The telco room is conditioned by a 2-ton package heat pump. Each unit has $450 \mathrm{cfm}$ of outside air and each zone has a dedicated $450 \mathrm{cfm}$ exhaust fan.

\section{Operating Schedules}

The Richland School is a year-round school using four tracks of students (see Table 16). The school year ended on June $26^{\text {th }}$ and the new year began on July $5^{\text {th }}$, so the school rooms were used sporadically during the week of July $1^{\text {st. }}$

\subsubsection{Data Acquisition Approach}

All sensors were continuously scanned and were summed or averaged in datalogger memory every 15 minutes. The datalogger had battery backup to protect against data loss during power outages. Data were downloaded nightly and all data ranges were reviewed the next day. Outof-range data were reported and investigated to determine whether a sensor or monitoring error existed or equipment had failed. Data were collected by Davis Energy Group and files were transferred to LBNL weekly during the monitoring period.

\subsubsection{Datalogger and Sensor Specifications}

\section{Datalogger}

A Data Electronics DT50 datalogger mounted in a NEMA 1 box was installed in the telco closet below an existing building EMCS panel (see Figure 17). The datalogger was provided with an RS232 communications interface, modem, and battery backup. A dedicated phone line was connected to the modem for nightly downloading of data.

\section{Surface Temperatures}

All surface temperatures were measured with Minco RTD thermal ribbon sensors connected to the data logger with 4-20ma current transducers. Roof surface sensors were placed just under the roofing felt and roof underside sensors were attached to the underside of the roof sheathing above the insulation (see Figure 18a \& b).

\section{Air Temperatures}

Plenum air temperature above the t-bar ceiling was measured in the middle of the plenum with a shielded AD592 semiconductor air sensor (see Figure 18c). Building interior temperatures were measured with a wall mounted AD592 semiconductor sensor placed next to the room HVAC sensor (see Figure 18d). 
Table 15. Richland Elementary School in San Marcos: HVAC specifications.

\begin{tabular}{l|lll}
\hline Unit No. & Room & Model & Monitoring Point \\
\hline HP-201 & Telco & Carrier 50JX-024-301 & AC2 \\
201 & Computer & Rheem RPKA-049CA2 & AC3 \\
202 & Computer & Carrier 38HD048C300 & AC3 \\
203 & Library/Resource Room & Carrier 38HD048C300 & AC1 \\
204 & Library & Carrier 38HD048C300 & AC2 \\
205 & $2-05$ & Carrier 38HD048C300 & AC1 \\
206 & $2-06$ & Carrier 38HD048C300 & AC2 \\
207 & $2-07$ & Carrier 38HD048C300 & AC1 \\
\hline
\end{tabular}


Table 16. Richland Elementary School in San Marcos: School track schedule during summer 2002.

\begin{tabular}{l|lll}
\hline Month & Tracks & \# of Students & Dates \\
\hline June & A,B,C & 766 & $5 / 28-6 / 26$ \\
July & B,C,D & 705 & $6 / 27-7 / 24$ \\
August & A,C,D & 664 & $7 / 25-8 / 01$ \\
\hline
\end{tabular}

Table 17. Richland Elementary School in San Marcos: Regression of air conditioner daily electricity use $\mathrm{E}(\mathrm{kWh})$ to temperature difference $\Delta \mathrm{T}=\mathrm{T}_{\text {out }}-\mathrm{T}_{\text {in }}\left({ }^{\circ} \mathrm{F}\right)$.

\begin{tabular}{|c|c|c|c|c|c|c|}
\hline \multirow[t]{2}{*}{ A/C System } & \multicolumn{3}{|l|}{ Pre1 } & \multicolumn{3}{|l|}{ Post1 } \\
\hline & a & $\mathrm{b}$ & $\mathrm{R}^{2}$ & a & $\mathrm{b}$ & $\mathrm{R}^{2}$ \\
\hline \multicolumn{7}{|l|}{$\mathrm{AC1}$} \\
\hline $\mathrm{E}=\mathrm{a}+\mathrm{b} \Delta \mathrm{T}$ & 50.6 & 3.03 & 0.73 & 43.1 & 2.45 & 0.36 \\
\hline
\end{tabular}

Notes: Total daily air-conditioning use is 2.6 times the AC1 electricity use. Pre1 period covers July 8 to July 28, 2002. Post1 period covers July 29 to August 20, 2002.

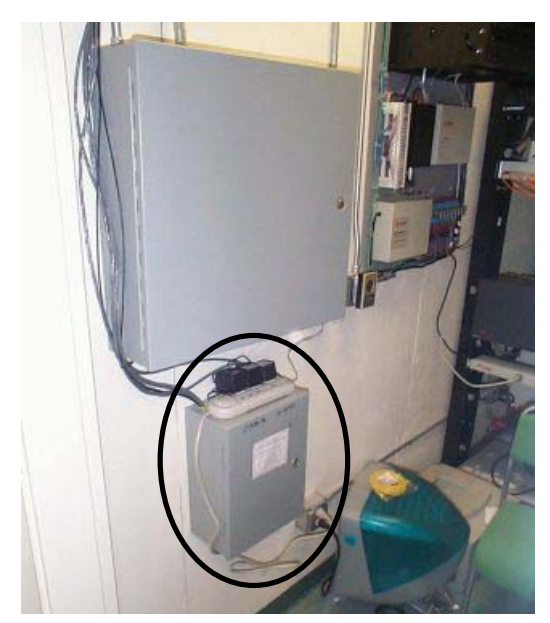

Figure 17. Richland Elementary School in San Marcos: Data logger location. 

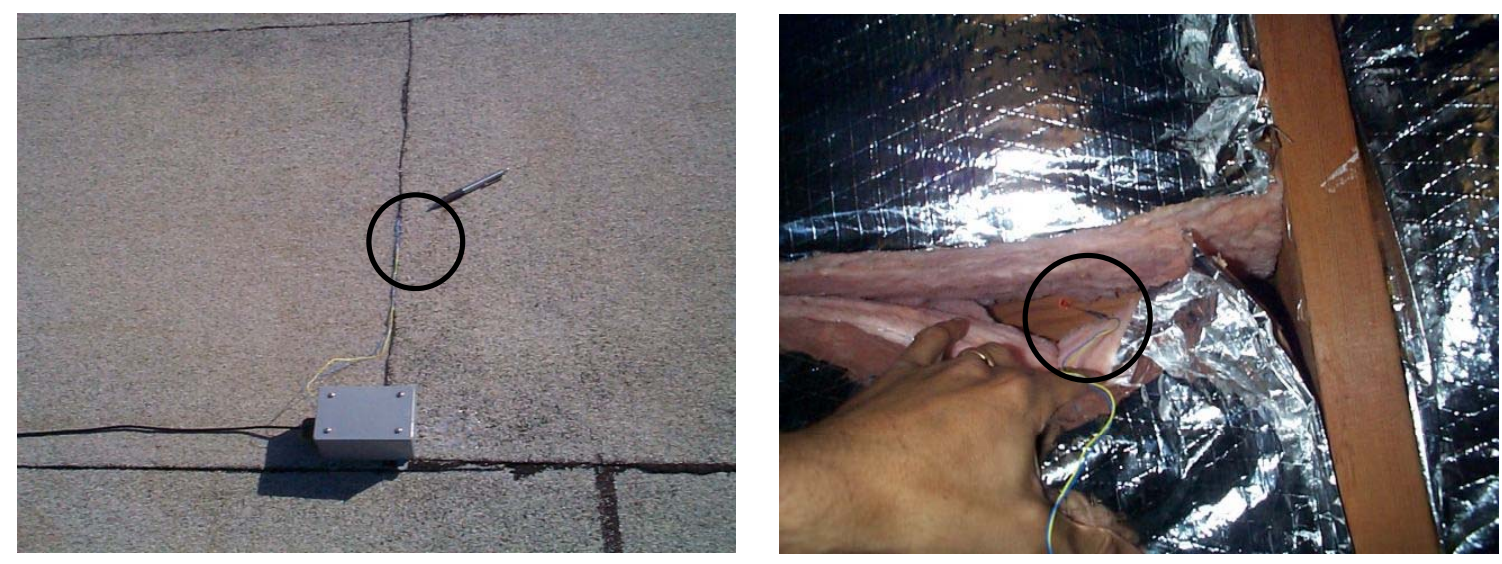

(a)

(b)
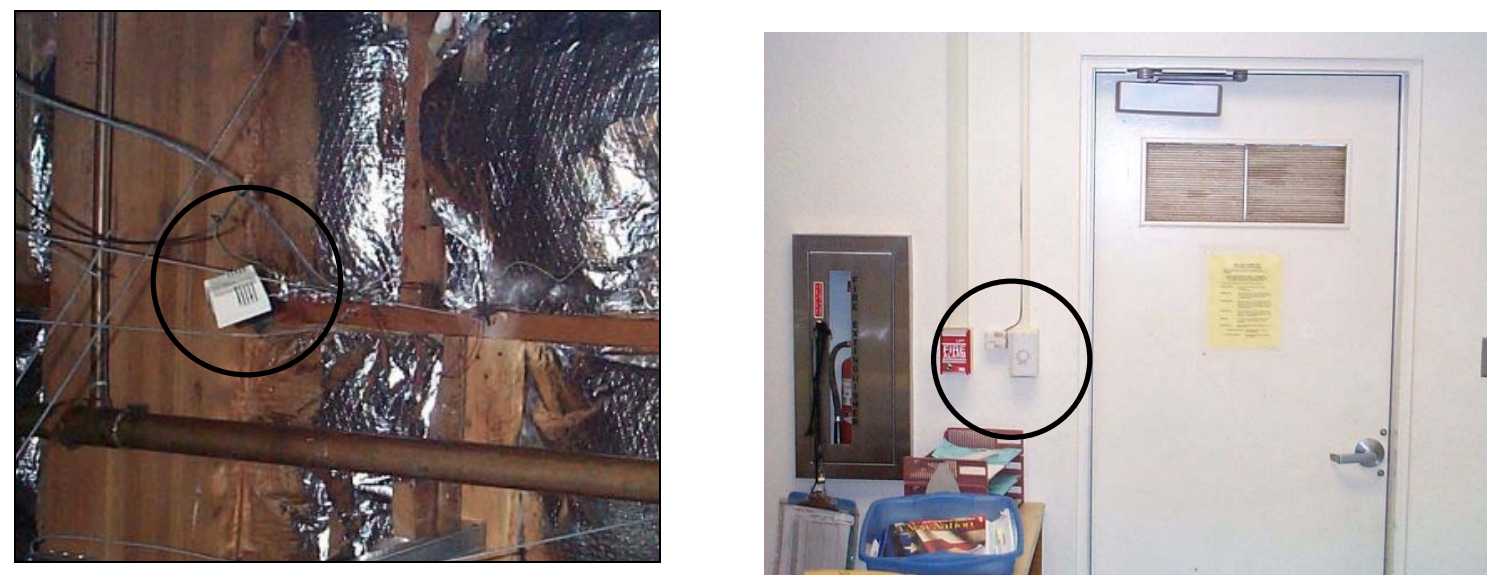

(c)

(d)

Figure 18. Richland Elementary School in San Marcos: Temperature sensors (a) roof surface, (b) roof underside, $(\mathrm{c})$ plenum air, and (d) room air.

\section{Weather Tower}

Three sensors were mounted to an existing weather tower mast on building \#3 (see Figure 19). Outdoor dry bulb and relative humidity were measured with an R.M. Young RH/temperature probe mounted in a Gill multi-plate radiation shield. Total horizontal solar isolation was measured with a Li-Cor LI-200SZ silicon photodetector.

\section{Power}

Air-conditioner, computer lab, and total building power were measured with Continental Control Systems 3P-208 WattNode power transducers mounted inside the building electrical panels located in the Teachers Resource Room (see Figure 20). Current was measured with Magnelab split-core current transformers. WAC1, WPB, and WTOT were installed initially, with WAC2 and WAC3 added on July 31. 


\subsubsection{Monitoring Period}

The instrumentation was installed on May 22, 2002. The system was debugged and data were calibrated during the period May 22-24, 2002. The pre-retrofit (Pre) data cover the period of May 24, 2002 to July 28, 2002 (65 days). The new roof membrane was installed beginning on July 29 and was completed on July 31. The post-retrofit (post) data cover the period of July 31 to September 30, 2002 (61 days). In order to improve the data quality and reduce uncertainty in the analysis, we continued monitoring the building for another year (from September 30, 2002 through September 30, 2003). However, in the detailed analysis of the summer 2003 data, we found that the operation of the building was fairly irregular and hence the added data did not improve the uncertainties in our analysis.

\subsubsection{Data Analysis and Results}

The first step in the analysis was to aggregate the validated 15-minute data into hourly and daily data. This was done for solar intensity, cooling electricity use, and total building electricity use. The temperature data were averaged to yield hourly and daily variables. In this process, questionable and missing data were identified and excluded from the analysis.

The parameters that can affect air-conditioning electricity use include outside temperature, inside temperature, solar heat gain, internal loads, relative humidity, and wind speed. A systematic regression analysis was performed in order to determine the sensitivity of the air-conditioning electricity use to these environmental parameters. The analysis was performed for the initial conditions before the roof was replaced with a reflective white membrane (May 28 to July 27, defined as Pre period) and for the conditions after the re-roofing (July 28 to September 30, defined as Post period). These regressions allowed normalizing the Pre and Post conditions for all parameters before making an attempt to estimate savings from the installation of the white roof membrane.

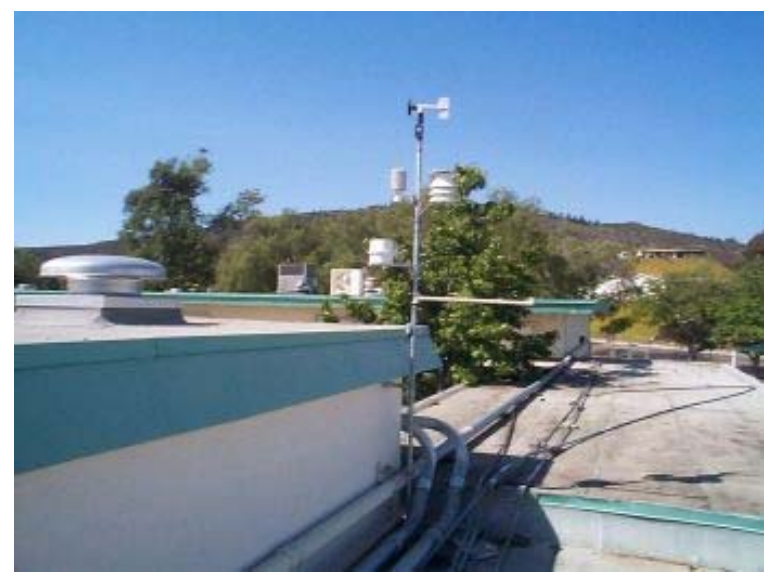

Figure 19. Richland Elementary School in San Marcos: Weather tower. 


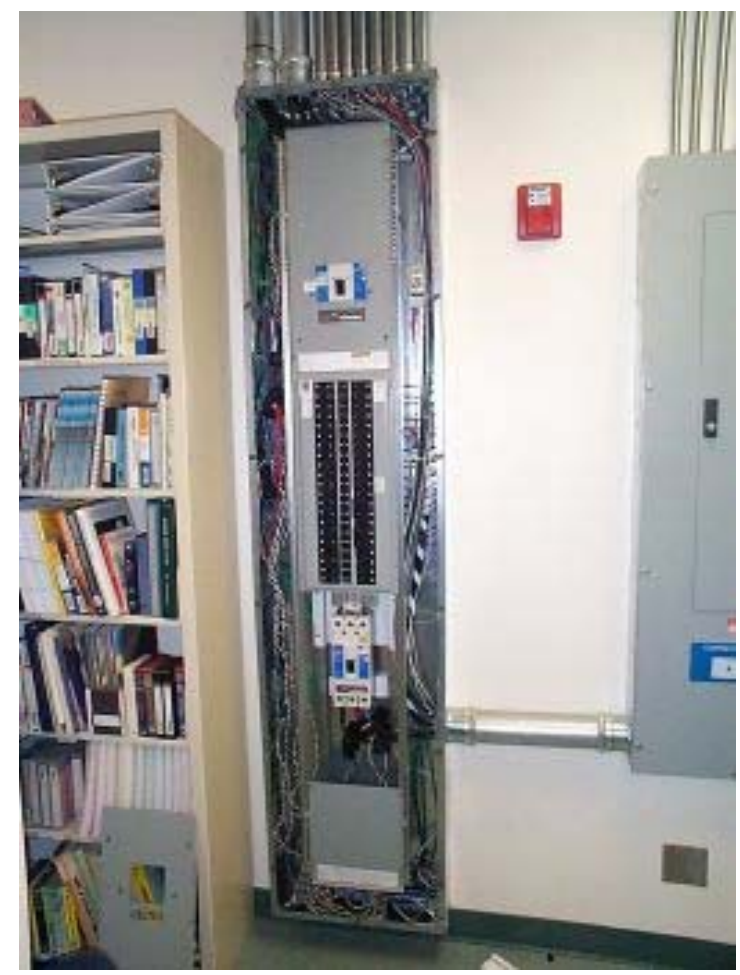

(a)

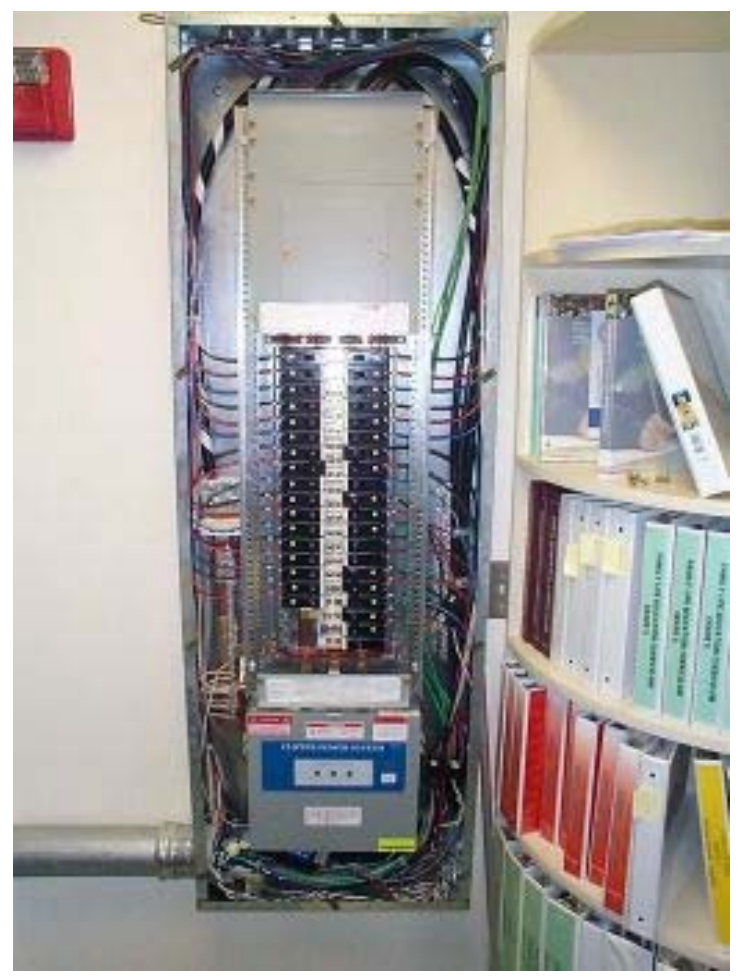

(b)

Figure 20. Richland Elementary School in San Marcos: Metering panels: (a) panel 2A, and (b) panel 2B.

\section{Temperature Data}

Figure 21 shows hourly temperature data for a two-week period before and after the building was re-roofed on July 29, 2002. Figure 21 shows the corresponding hourly temperatures averaged over the Pre and Post periods. Figure 22 shows the average outdoor hourly temperatures for the Post period is about $4-5^{\circ} \mathrm{F}$ higher than those of the Pre period. The maximum surface temperature in the Pre period is about $70^{\circ} \mathrm{F}$ higher than the ambient air temperature. For the Post period, the maximum surface temperature is only a few degrees higher than the ambient temperature. Hence, the maximum surface temperature was reduced by about $65^{\circ} \mathrm{F}$ after re-roofing. The minimum nighttime surface temperature for the Pre and Post periods can get about $10-15^{\circ} \mathrm{F}$ cooler than ambient air temperature. This is mostly because of radiative nighttime cooling to the sky.

The under-roof temperature in both locations ' $\mathrm{A}$ ' and ' $\mathrm{B}$, is about $40-50^{\circ} \mathrm{F}$ higher in the Pre period compared to Post period. The air temperature in the plenum is only about $4-5^{\circ} \mathrm{F}$ higher in the Pre period compared to Post period. The plenum temperature is highly influenced by the interior air conditioning. This is evident by noting that the plenum temperature during the hours when the air conditioning is operating is about the same for Pre and Post periods. For hours 17 to 20 (when the air-conditioners are typically off and the plenum temperature is mostly affected by the heat conducted through the roof) is about $4^{\circ} \mathrm{F}$ warmer during the Pre 
period than the Post period. The plenum is not mechanically ventilated, but there is some leakage around the room vent penetration that allows cool air to escape to the plenum.

The inside temperature in all three areas measured is typically kept in the range of $72-75^{\circ} \mathrm{F}$. It appears that the inside temperature during the first few days of Post period is about $2^{\circ} \mathrm{F}$ cooler than a few days of Pre period just before re-roofing. Figure $\mathbf{2 3}$ shows the same data averaged for a three-week period before and after re-roofing. For these three-week periods, the average outdoor temperature for Pre and Post are similar.

\section{Air Conditioning Energy Use and Savings}

Figure 24 shows the hourly and daily electricity use monitored by points AC1 (Units 203, 205, and 207), AC2 (HP201, Units 204 and 206), AC3 (Units 201 and 202), and OTH (other uses: lighting, computers, etc.). The hourly data are shown for a period of two weeks before and after the installation of reflective roof; the daily data are for the entire monitoring period through September 30. We have continuous data only for AC1 and total building electricity use over the entire Pre and Post periods. For the two-week periods before and after re-roofing, the hourly data for $\mathrm{AC} 1$ shows a peak consumption of about $8 \mathrm{~kW}$ for the Pre period and about $6 \mathrm{~kW}$ for the Post period. This suggests a decrease in peak hourly electricity use of AC1 of about 2kW. During the Post period, the hourly peak consumption for AC2 and AC3 is about $5 \mathrm{~kW}$. If we assume the same amount of saving achieved in AC2 (but not AC3, since AC3 is mostly for cooling the internal load of the computer room) a rough estimate of total AC savings is about $4 \mathrm{~kW}$. We will statistically quantify peak demand savings later on. 

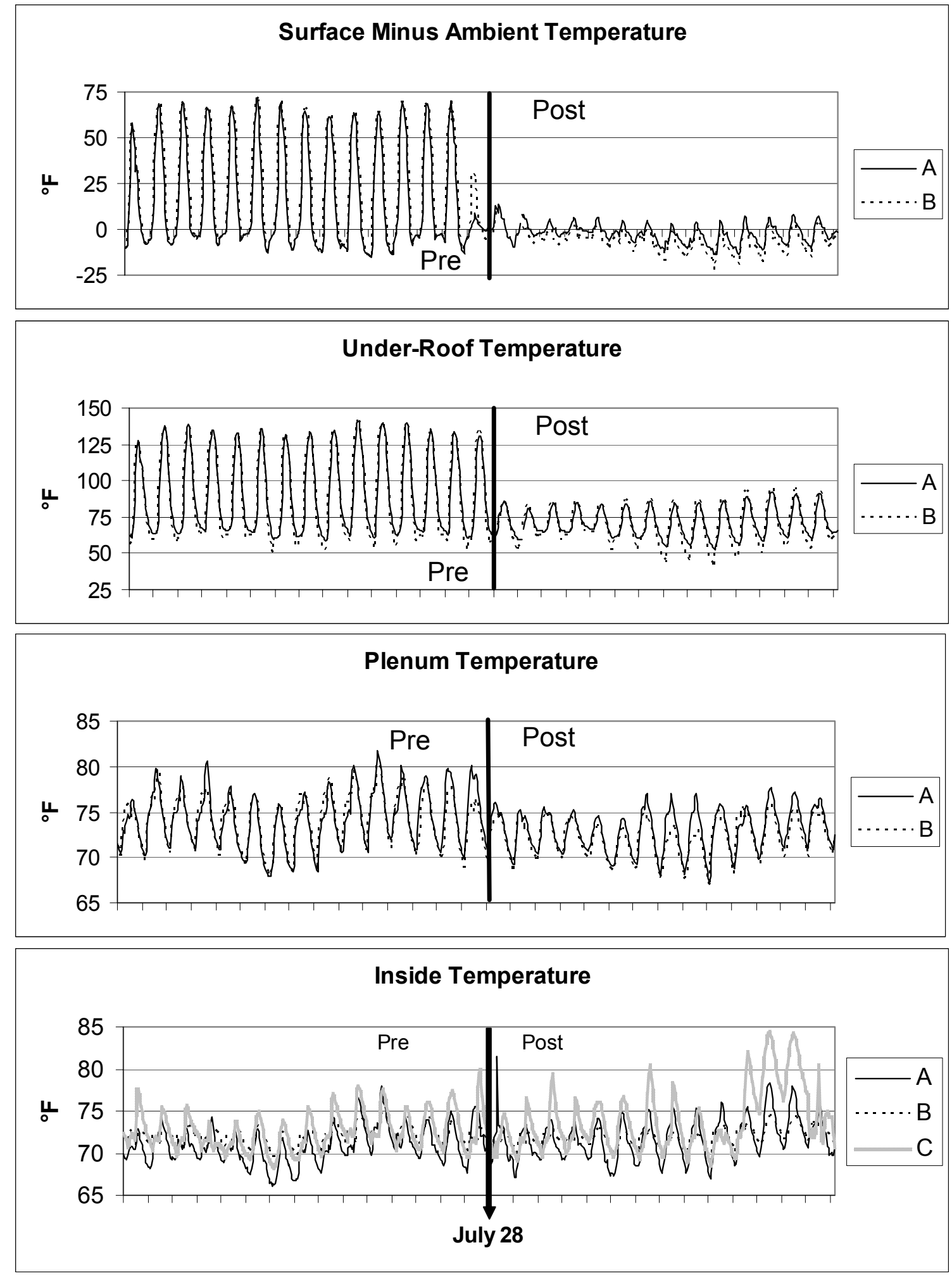

Figure 21. Richland Elementary School in San Marcos: Hourly temperatures for two-week periods before and after installation of the white roof membrane on July 28,2002 . ' $\mathrm{A}$ ', ' $\mathrm{B}$ ', and ' $\mathrm{C}$ ' are measurements at three locations on the roof. Time interval $=$ day. 

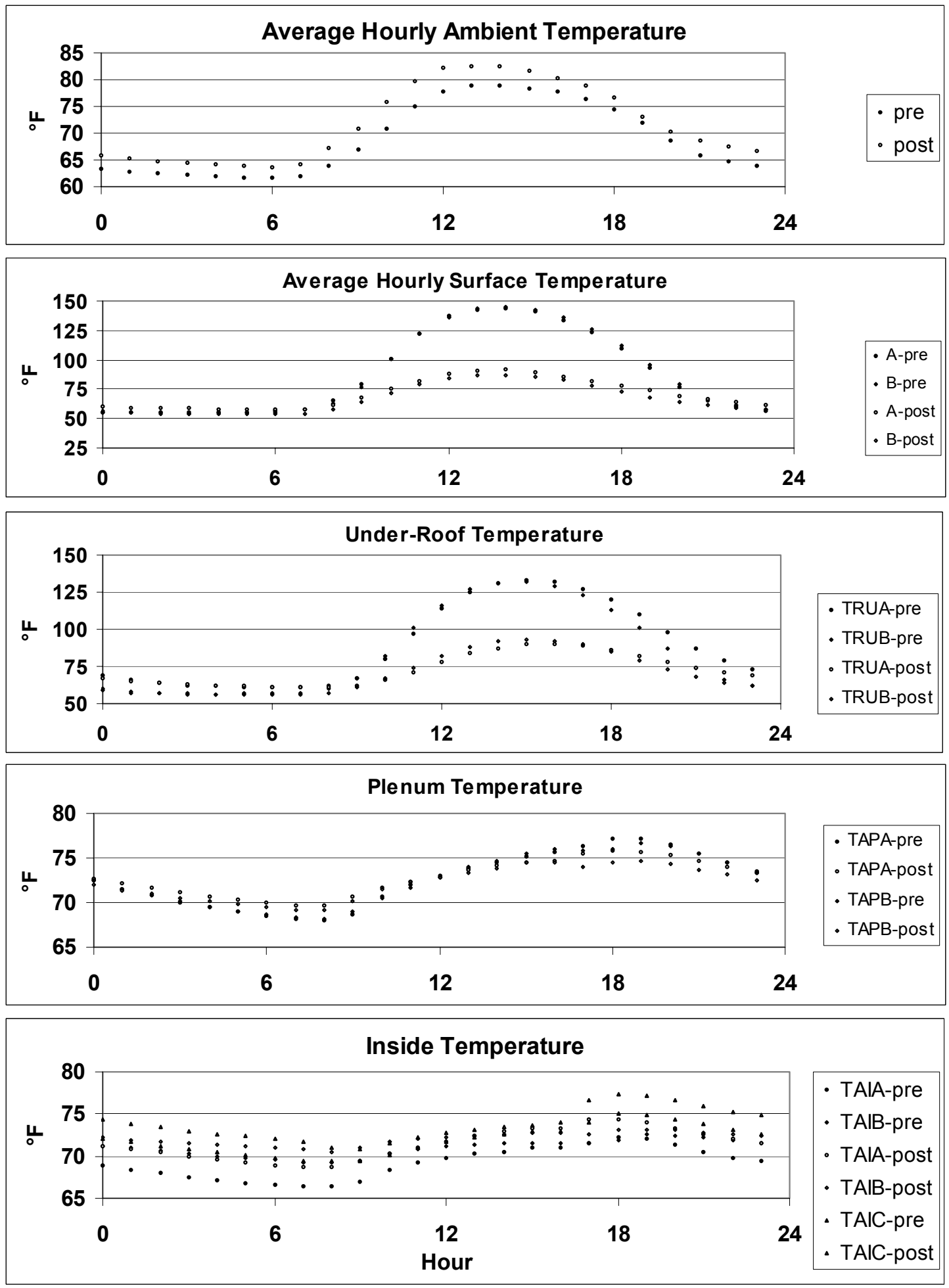

Figure 22. Richland Elementary School in San Marcos: Average hourly temperatures before (Pre) and after (Post) installation of the white roof membrane. ' $\mathrm{A}$ ', ' $\mathrm{B}$ ', and ' $\mathrm{C}$ ' are measurements at three locations on the roof; 'TRUA' and 'TRUB,' are under-roof temperatures at locations ' $\mathrm{A}^{\prime}$ ' and ' $\mathrm{B}$ '; 'TAPA' and 'TAPB' are plenum air temperature at locations ' $\mathrm{A}$ ' and ' $\mathrm{B}^{\prime}$; 'TAIA,' 'TAIB,' and 'TAIC' are inside air temperature at locations ' $\mathrm{A}$ ', ' $\mathrm{B}$ ', and ' $\mathrm{C}$ ', respectively . 

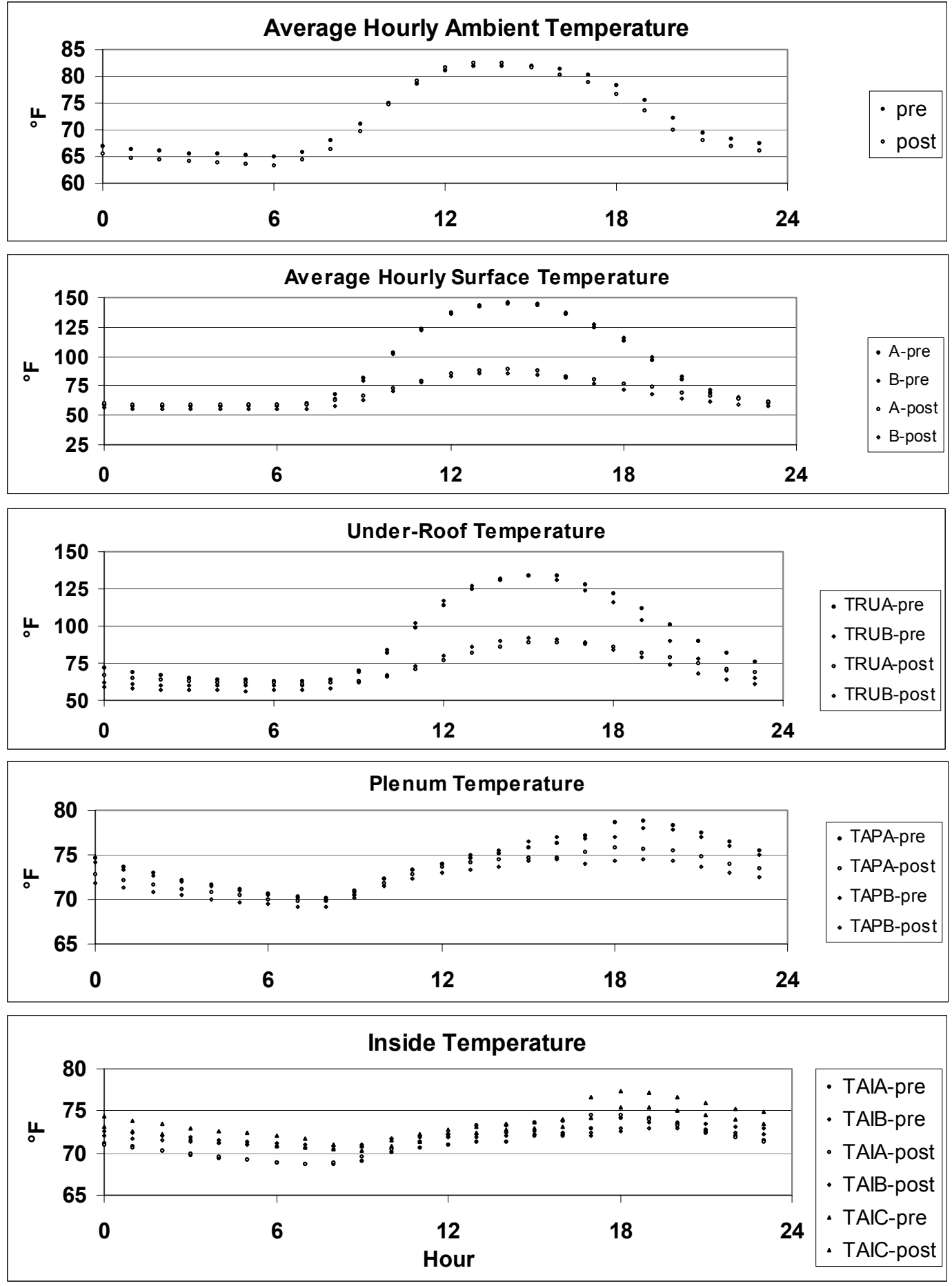

Figure 23. Richland Elementary School in San Marcos: Average hourly temperatures for three weeks before (Pre) and three weeks after (Post) installation of the reflective roof. ' $\mathrm{A}$ ', ' $\mathrm{B}$ ', and ' $\mathrm{C}$ ' are measurements at three locations on the roof; 'TRUA' and 'TRUB,' are under-roof temperatures at locations ' $\mathrm{A}$ ' and ' $\mathrm{B}^{\prime}$; 'TAPA' and 'TAPB' are plenum air temperature at locations ' $\mathrm{A}$ ' and ' $\mathrm{B}$ '; 'TAIA,' 'TAIB,' and 'TAIC' are inside air temperature at locations ' $\mathrm{A}^{\prime}$, ' $\mathrm{B}^{\prime}$, and ' $C$ ', respectively . 

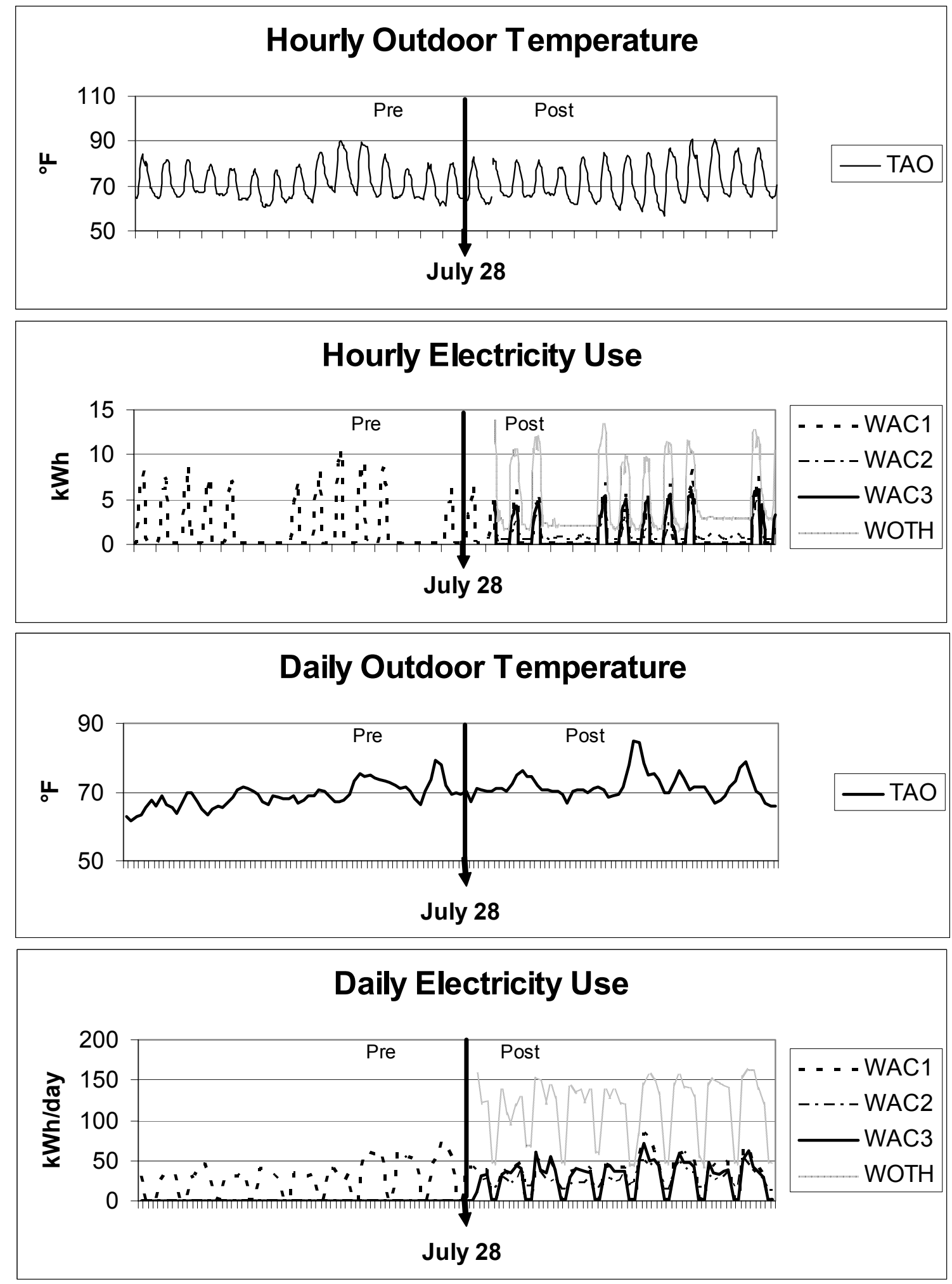

Figure 24. Richland Elementary School in San Marcos: Hourly and daily air conditioning energy uses. 'TAO' is the outdoor air temperature and 'WAC1', 'WAC2', 'WAC3', and 'WOTH' are the electricity use for AC1, AC2, AC3, and "other" end uses. Time interval = day. 
A close inspection of the daily data for $\mathrm{AC} 1$ shows that during the Pre period the operation of the system is different for the period of May 28 to July 8 (we define this period as "Pre0"; AC1 use of about $40 \mathrm{kWh}$ per day) than that of the period July 8 to July 28 (we define this period as "Pre1"; AC1 use of about 60kWh per day). Hence, if we compare AC1 usage for three weeks before (Pre1) re-roofing and five weeks after re-roofing, a daily energy saving of about $15 \mathrm{kWh}$ can be observed. However, if we compare the data for the entire Pre and Post period the savings are not that apparent. The high fluctuation in daily consumption is mainly due to the fact that the operations of the classrooms do not follow a long-term regular schedules. The same difference in operation can be observed by inspecting the total daily electricity use for the building (Figure 25). The daily total electricity use for Pre1 is about $270 \mathrm{kWh}$ and for five weeks after re-roofing, the daily use is about $240 \mathrm{kWh}$. But after the fifth week, the Post-period consumption reaches up to $350 \mathrm{kWh}$.

Figure 26 shows the daily air-conditioning electricity use for AC1 as a function of the difference between outside and inside temperatures $\left(\Delta \mathrm{T}=\mathrm{T}_{\text {out }}-\mathrm{T}_{\mathrm{in}}\right)$. We performed statistical analysis of AC1 electricity use versus difference between outside and inside temperatures $(\Delta T)$ and daily total insolation. The results showed significant correlation between the A/C electricity use and temperature difference. The regressions against insolation were not statistically significant and did not improve the overall regression models. The regression results for the entire monitoring period indicate the temperature normalized electricity use consumption during the Post period is higher than that of the Pre period. This was expected, as the operational schedules of classrooms are intensified during the Post period. To further investigate this change in the operation of the building, we regressed the AC1 use for the Pre period into two groups of Pre0 and Pre1; the results are shown in Figure 27 (the time intervals for Pre0 and Pre1 periods were defined earlier.) Figure 27 clearly shows that the temperature-normalized consumption for AC1 is about $15 \mathrm{kWh}$ per day higher in the Pre1 than that of Pre0. Hence, to be consistent in our analysis, we focused on a three-week period before (Pre1) and after (Post1: July 29 to August 20, 2002) the re-roofing, when the operation of the classrooms appeared to be the same based on the comparison of OTH electricity use (other, non-cooling end uses). This analysis is summarized in Figure 28 and Table 17. According to Figure 28, the AC1 electricity use dropped by about $8-10 \mathrm{kWh}$ per day after the roof was replaced with a white membrane.

Using the correlation in Table 17, we estimated the AC1 air conditioning daily electricity use for the building, for the analysis period of July 8 to August 20, 2002. During the Pre1 period (July 8 to July 28, 2002), the daily average AC1 use was $57 \mathrm{kWh}$ per day. During the Post1 period (July 29 to August 20, 2002), the average daily A/C electricity use was $42 \mathrm{kWh}$ per day. As it is shown in Figure 23, the average outdoor temperature during the Pre1 and Post1 period was fairly similar. Hence, without correcting for weather conditions of the Pre1 and Post1 periods, the savings are estimated at $15 \mathrm{kWh} /$ day $(27 \%)$. Using the difference of average outdoor and indoor temperatures $(\Delta \mathrm{T})$, the savings are estimated at $8.9 \mathrm{kWh} /$ day and $7.3 \mathrm{kWh} /$ day $(15 \%)$ for Pre1 and Post1 periods, respectively.

The daily AC1 electricity savings slightly increases with increasing outdoor temperature. When the daily difference of outdoor and indoor temperature $(\Delta \mathrm{T})$ is $7^{\circ} \mathrm{F}$ the estimated cooling electricity use is $72 \mathrm{kWh} /$ day and $60 \mathrm{kWh} /$ day for Pre1 and Post1 period, respectively. The estimated savings for both periods is $12 \mathrm{kWh} /$ day $(16 \%)$. Both estimates indicate savings in excess of $15 \%$. 


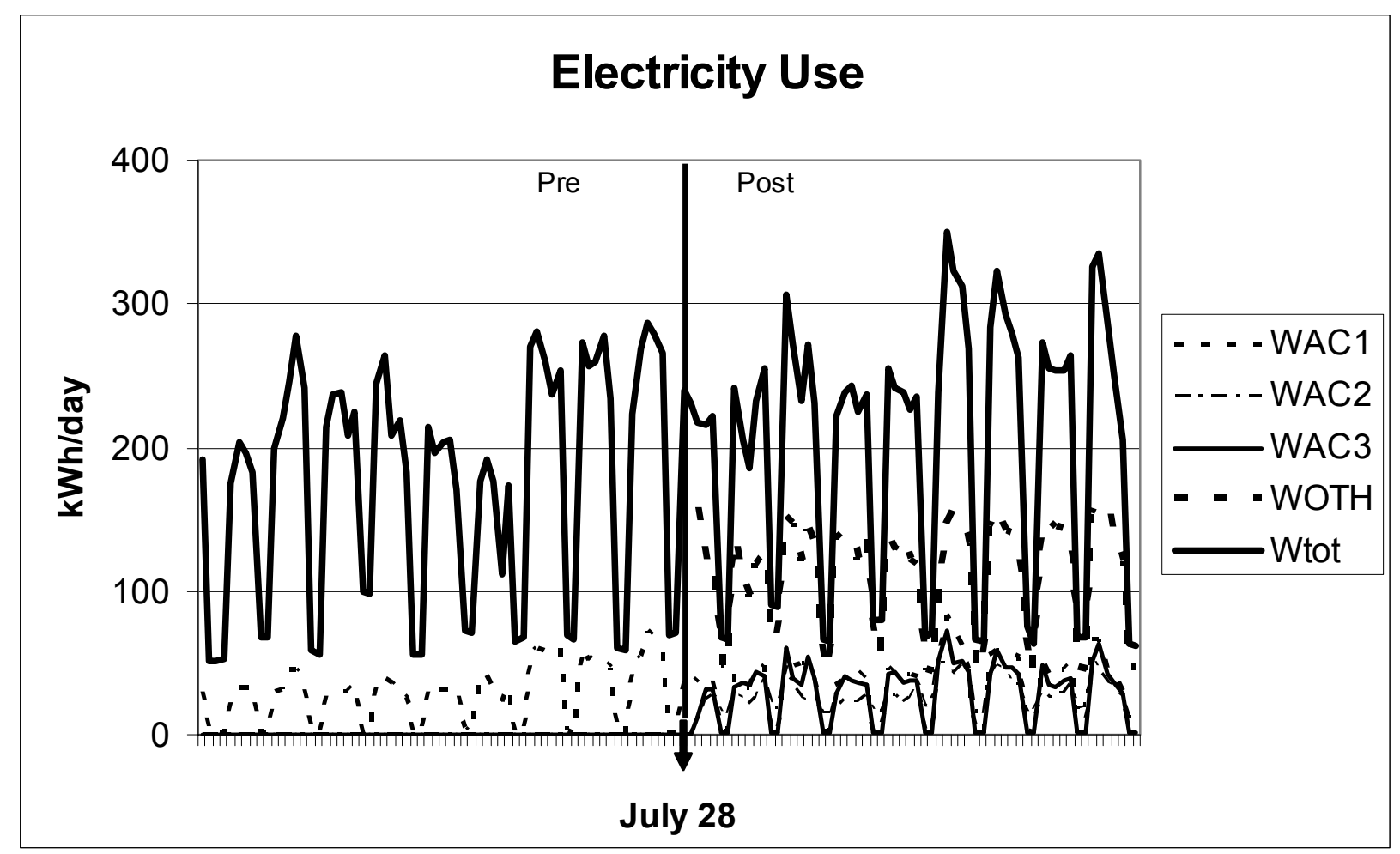

Figure 25. Richland Elementary School in San Marcos: Daily electricity use. Note the significant change in total energy use between the Pre and Post periods. 'WAC1', 'WAC2', 'WAC3', and 'WOTH' are the electricity use for AC1, AC2, AC3, "other" end uses, and 'Wtot' is total building electricity use. Time interval $=$ day. 

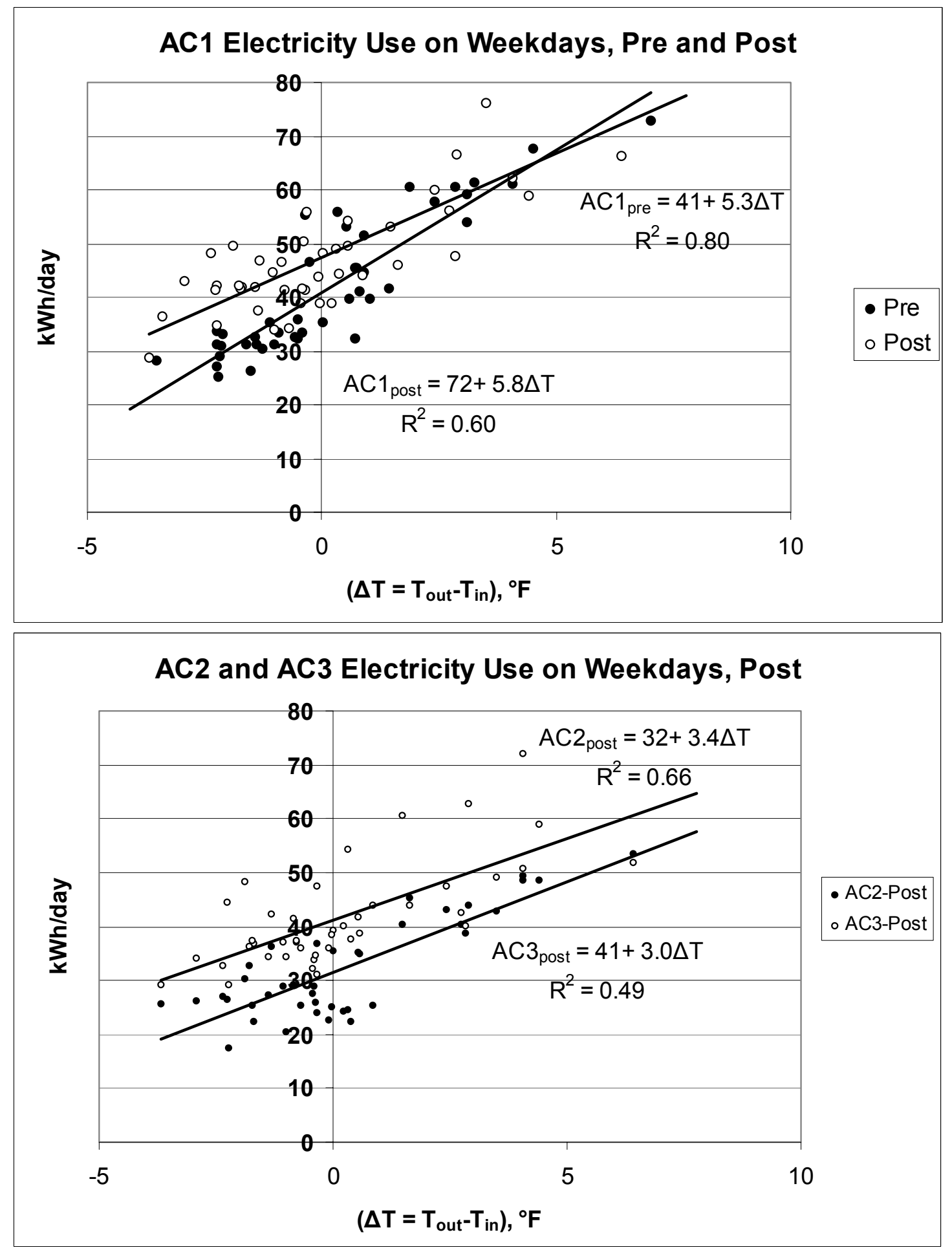

Figure 26. Richland Elementary School in San Marcos: Daily electricity uses for weekdays during Pre and Post periods for $\mathrm{AC} 1, \mathrm{AC} 2$, and $\mathrm{AC} 3$ as a function of daily outdoor and indoor temperature difference $\left(\triangle T=T_{\text {out }}-T_{\text {in }}\right)$. 'AC1', 'AC2', and 'AC3' are daily use for three airconditioning systems. "Pre" period is from May 28 to July 28, 2002. "Post" period covers July 29 to September 30, 2002. 


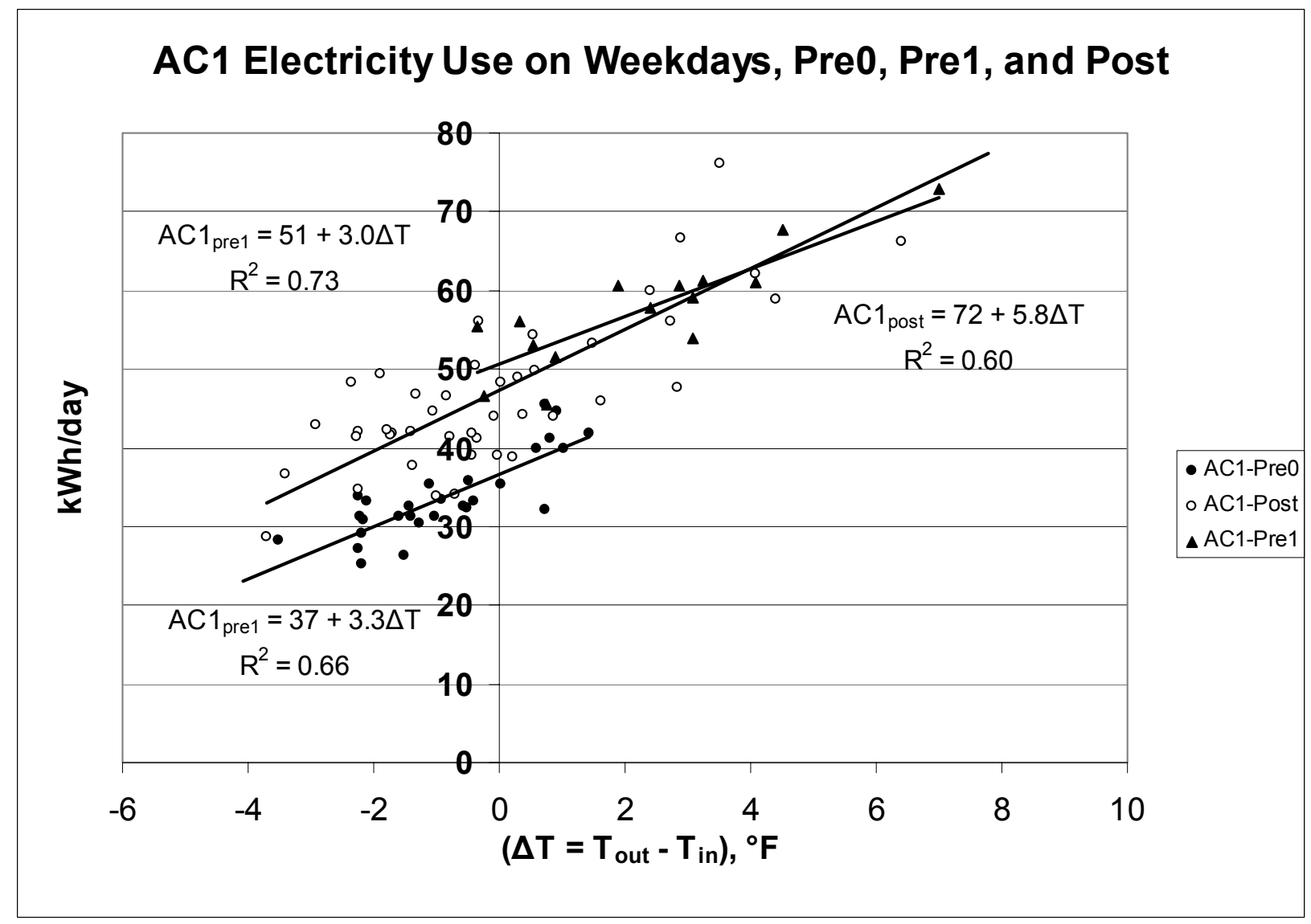

Figure 27. Richland elementary school in San Marcos: Daily electricity use for weekdays during Pre0, Pre1, and Post periods for AC1 as a function of daily outdoor and indoor temperature difference $\left(\Delta T=T_{\text {out }}-T_{\text {in }}\right)$. "Pre0" period is from May 28 to July 7, 2002. "Pre1" period covers July 8 to July 28, 2002. "Post" period covers July 29 to September 30, 2002. 

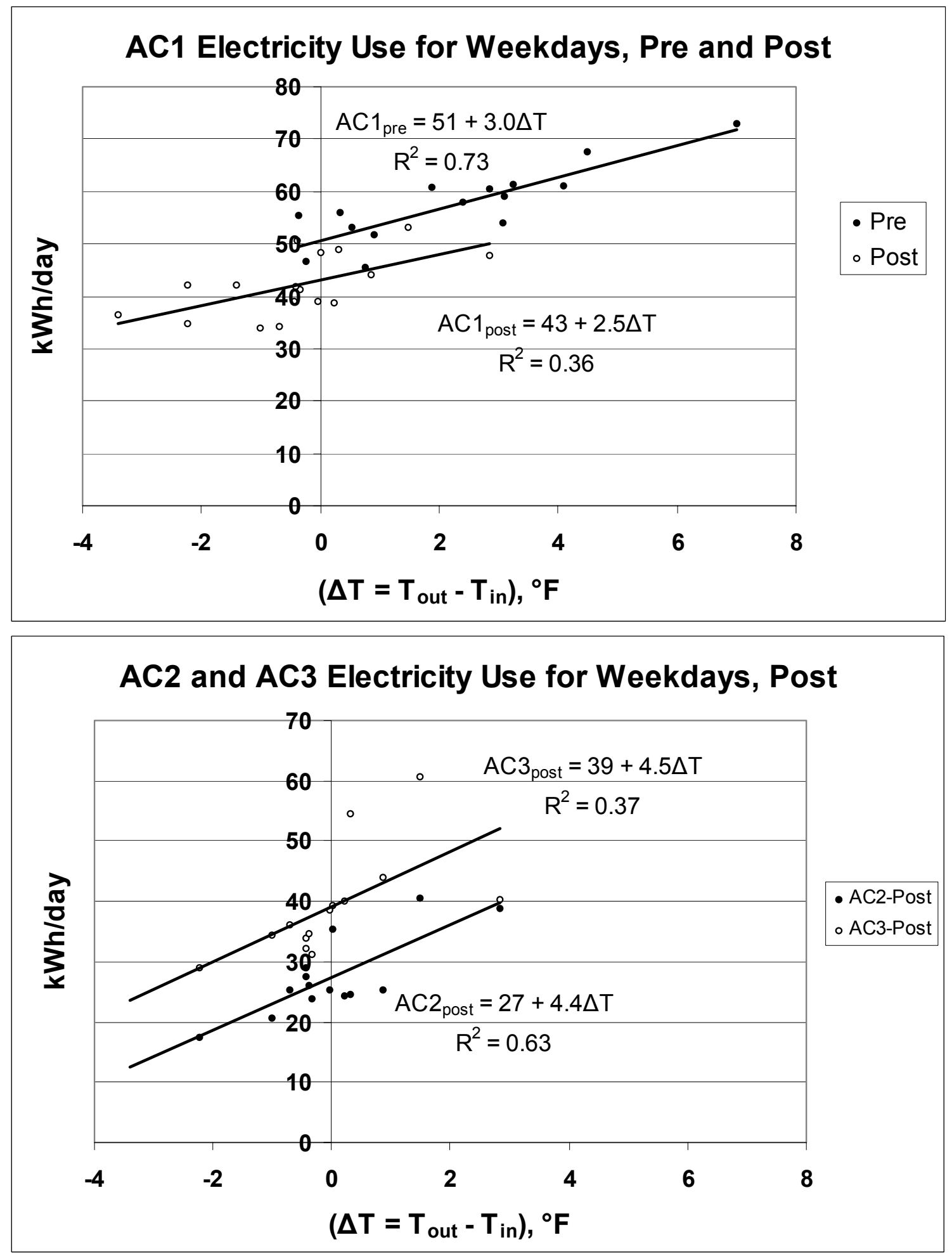

Figure 28. Richland Elementary School in San Marcos: Daily electricity use for weekdays for $A C 1, A C 2$, and $A C 3$ as a function of daily outdoor and indoor temperature difference $\left(\Delta T=T_{\text {out }}\right.$ - $\mathrm{T}_{\text {in) }}$, for 3 weeks before (Pre) and after (Post) installing cool roof. "Pre" period covers July 8 to July 28, 2002. "Post" period covers July 29 to August 20, 2002. 
As we discussed earlier, for the "Pre" period we monitored the total building and AC1 electricity use. For the "Post" period, in addition to total building and AC1 electricity use, we monitored the electricity use for the two other air-conditioning systems of AC2 and AC3. Analysis of the data for the "Post" period indicated a very close correlation between the total $\mathrm{A} / \mathrm{C}$ use $\left(\mathrm{AC}_{\text {tot }}=\mathrm{AC1}+\mathrm{AC} 2+\mathrm{AC} 3\right)$ and the $\mathrm{AC} 1$ electricity use (see Figure 29). The regression results indicate that for weekdays $\mathrm{AC}_{\text {tot }}$ use is about 2.5 times the $\mathrm{AC} 1$ electricity use. We used this scaling factor to estimate $\mathrm{AC}_{\text {tot }}$ electricity savings for "Pre1" and "Post1" periods; the results are shown in the lower half of Table 18.

During the Pre1 period the daily average $\mathrm{AC}_{\text {tot }}$ use was $146 \mathrm{kWh} /$ day. During the Post1 period, the average daily $\mathrm{AC}_{\text {tot }}$ electricity use was $107 \mathrm{kWh} /$ day. Hence, without correcting for weather conditions of the Pre 1 and Post 1 period, the savings are estimated at $39 \mathrm{kWh} /$ day $(27 \%)$. Using the difference of average outdoor and indoor temperatures $(\Delta \mathrm{T})$, the savings are estimated at 23 kWh/day and $19 \mathrm{kWh} /$ day (15\%) for Pre1 and Post1 periods, respectively.

The data collected during summer of 2003 showed significant variations in operation schedules from those of 2002. Hence, we did not use the 2003 data in our analysis of energy savings.

\section{Air Conditioning Peak Demand and Savings}

To estimate the effect of the cool roof on peak electricity demand, we inspected the hourly total building electricity use for hours 10 through 17, for the "Pre1" and "Post1" periods (see Figure 30). Figure 30 clearly depicts a visible reduction in hourly A/C electricity use for all hours but hours 10 and 14. For most hours, the peak demand reductions appear to be higher for higher outdoor temperature. We correlated the total hourly electricity use with the hourly outdoor temperature; the correlation statistics are summarized in Table 19. The correlations indicate that the average (for hours 10-16) peak demand savings is about $3.1 \mathrm{~kW}$ when the outside temperature is $90^{\circ} \mathrm{F}\left(2.8 \mathrm{~kW}\right.$ for $\left.80^{\circ} \mathrm{F}\right)$.

As it was mentioned in the analysis of energy savings, the data collected during summer of 2003 showed significant variations in operation schedules than those of 2002. Hence, we did not use the 2003 data in our analysis of peak demand savings.

\section{Simulated Air Conditioning Energy Use and Savings}

\section{Building Description}

The detailed building characteristics data used for simulation of the school are summarized in Table 20. The building was modeled as a 6,140 $\mathrm{ft}^{2}$ single-story wood frame structure containing three classrooms, a library, and a computer laboratory. The building has exterior hallways and extensive single glazing facing northeast. The three classrooms and the computer lab each have an area of $960 \mathrm{ft}^{2}$, the library has 1,920 ft', and the restroom area is $380 \mathrm{ft}^{2}$. The ceiling ceilings height in all zones is 9 feet. The roof is insulated with 8" fiberglass batt (R-30) attached to the underside of the roof sheathing. It has a plenum on top of the dropped t-bar ceiling with $3 / 4$ " acoustical tile. The roof construction includes the roofing membrane installed on a wood deck. All windows are single-glazed with operable shades located on the north side of the building. 

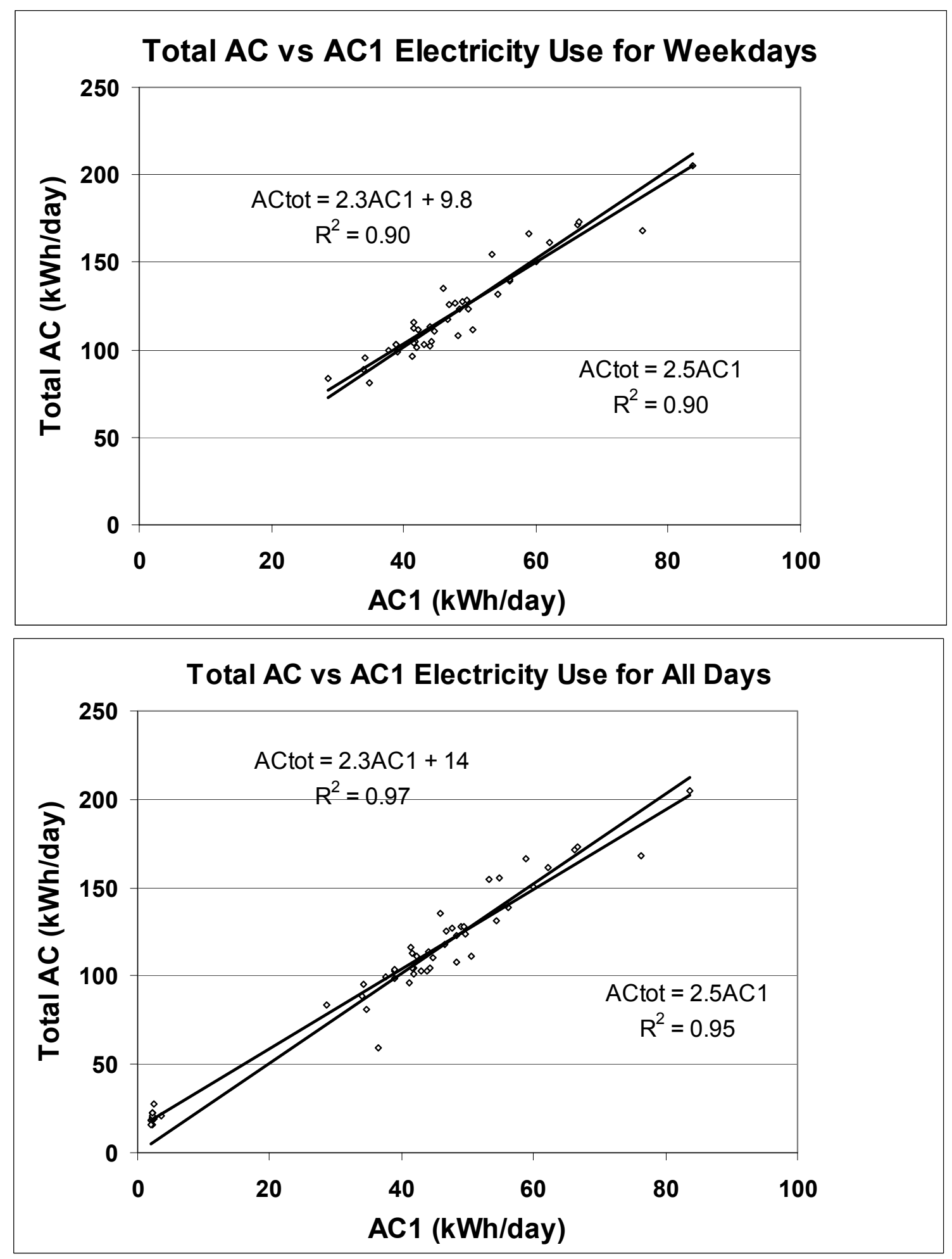

Figure 29. Richland Elementary School in San Marcos: Correlations between total airconditioning daily electricity use and $\mathrm{AC} 1$ daily electricity use. The correlations are for the entire "Post" period of July 29 to September 30, 2002. 
Table 18. Richland Elementary School in San Marcos: Estimates of daily A/C electricity savings.

\begin{tabular}{|l|l|l|l|l|l|l|}
\hline \multirow{2}{*}{ A/C System } & \multicolumn{3}{|c|}{ Pre1: July 8 to July 28 } & \multicolumn{3}{c|}{ Post1: July 29 to August 20 } \\
\cline { 2 - 7 } & $\begin{array}{l}\text { Base use } \\
(\mathrm{kWh} / \mathrm{d})\end{array}$ & $\begin{array}{l}\text { Savings } \\
(\mathrm{kWh} / \mathrm{d})\end{array}$ & $\begin{array}{l}\text { Savings } \\
(\%)\end{array}$ & $\begin{array}{l}\text { Base use } \\
(\mathrm{kWh} / \mathrm{d})\end{array}$ & $\begin{array}{l}\text { Savings } \\
(\mathrm{kWh} / \mathrm{d})\end{array}$ & $\begin{array}{l}\text { Savings } \\
(\%)\end{array}$ \\
\hline $\begin{array}{l}\text { AC1 } \\
\text { (a) Daily Average }\end{array}$ & $\mathbf{5 7 . 5}$ & 8.9 & 15 & $\mathbf{4 2 . 1}$ & 7.3 & 15 \\
\hline (b) $\Delta \mathrm{T}=7^{\circ} \mathrm{F}$ & $\mathbf{7 1 . 9}$ & 11.6 & 16 & $\mathbf{6 0 . 3}$ & 11.6 & 16 \\
\hline $\begin{array}{l}\text { AC } \mathrm{tot}_{\mathrm{t}} \\
\text { (a) Daily Average }\end{array}$ & $\mathbf{1 4 6}$ & 22.6 & 15 & $\mathbf{1 0 7}$ & 18.5 & 15 \\
\hline (b) $\Delta \mathrm{T}=7^{\circ} \mathrm{F}$ & $\mathbf{2 1 . 9}$ & 29.4 & 16 & $\mathbf{1 5 3}$ & 29.4 & 16 \\
\hline
\end{tabular}

Notes: "Pre" (July 8 to July 28) shows estimates of savings (a) average measured daily A/C use and (b) projected $A / C$ use when $\Delta T=T_{\text {out }}-T_{\text {in }}=7^{\circ} \mathrm{F}$. "Post" shows analogous data for the period of July 29 to August 20, 2002. AC tot use is 2.535 times AC1 use.

Table 19. Richland Elementary School in San Marcos: Regression of total building power demand $\mathrm{P}(\mathrm{kW})$ to outside air temperature $\mathrm{T}_{\text {out }}\left({ }^{\circ} \mathrm{F}\right)$ via relation $\mathrm{P}=\mathrm{a}+\mathrm{bT}$.

\begin{tabular}{|c|c|c|c|c|c|c|}
\hline \multirow[t]{2}{*}{ Hour } & \multicolumn{3}{|l|}{ Pre1 } & \multicolumn{3}{|l|}{ Post1 } \\
\hline & $a$ & $\mathrm{~b}$ & $\mathrm{R}^{2}$ & $\mathrm{a}$ & $\mathrm{b}$ & $\mathrm{R}^{2}$ \\
\hline 10 & -22.1 & 0.55 & 0.59 & -8.7 & 0.37 & 0.22 \\
\hline 11 & -18.9 & 0.53 & 0.64 & -7.7 & 0.36 & 0.20 \\
\hline 12 & -10.3 & 0.43 & 0.39 & -4.6 & 0.34 & 0.21 \\
\hline 13 & 1.0 & 0.30 & 0.21 & -11.1 & 0.42 & 0.30 \\
\hline 14 & 8.6 & 0.20 & 0.10 & -25.9 & 0.61 & 0.22 \\
\hline 15 & 7.0 & 0.26 & 0.20 & -16.0 & 0.50 & 0.15 \\
\hline 16 & $\begin{array}{l}-7.1 \\
\end{array}$ & 0.41 & 0.44 & 30.8 & -0.15 & 0.01 \\
\hline 17 & -1.0 & 0.17 & 0.12 & 16.7 & -0.08 & 0.01 \\
\hline 10-16 Average & -6.0 & 0.38 & & -6.2 & 0.35 & \\
\hline
\end{tabular}

Notes: The average peak demand savings is about $3.1 \mathrm{~kW}$ when the outside temperature is $90^{\circ} \mathrm{F}$. "Pre1" period covers July 8 to July 28, 2002. "Post1" period covers July 29 to August 20, 2002. 

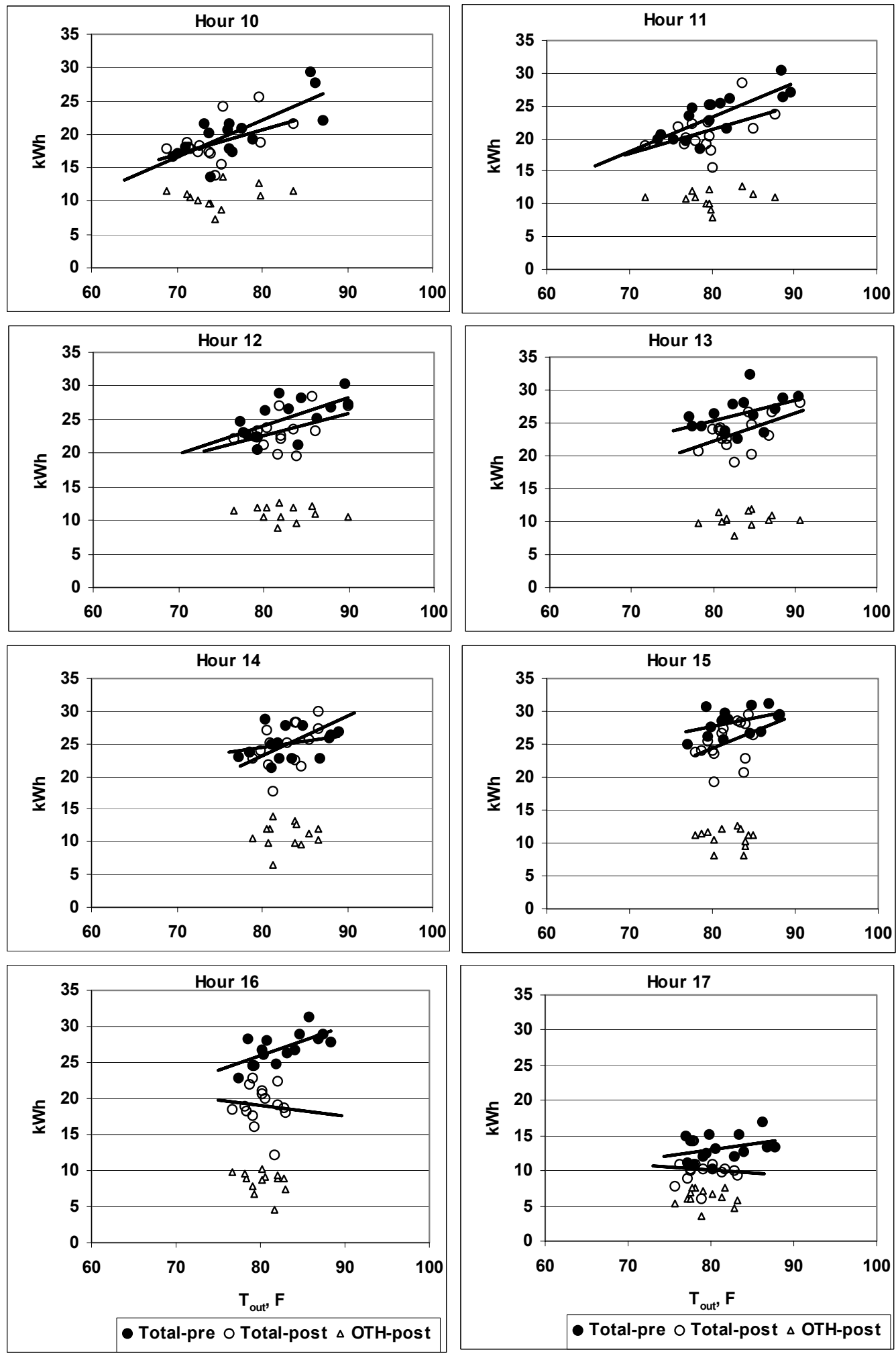

Figure 30. Richland Elementary School in San Marcos: Electrical demand as a function of outdoor temperature ( $\left.\mathrm{T}_{\text {out }}\right)$ for 3 weeks before and after installation of the cool roof. "Pre" period covers July 8 to July 28, 2002. “Post” period covers July 29 to August 20, 2002. 
Table 20. Richland Elementary School in San Marcos: Building description.

\begin{tabular}{|c|c|c|}
\hline \multicolumn{3}{|l|}{ General } \\
\hline & Single-Story Classroom Module & $6144 \mathrm{ft}^{2}$ \\
\hline & Orientation & $\mathrm{Ne}\left(337.5^{\circ}\right)$ \\
\hline & North/South & $192^{\prime}$ \\
\hline & East/West & $32^{\prime}$ \\
\hline & Location & San Marcos, S. CA \\
\hline & Weather Site & Ctz10 \\
\hline \multicolumn{3}{|l|}{ Zones } \\
\hline & Classroom 2-05 & $960 \mathrm{ft}^{2}\left[9^{\prime}\right]$ \\
\hline & Classroom 2-06 & $960 \mathrm{ft}^{2}\left[9^{\prime}\right]$ \\
\hline & Classroom 2-07 & $960 \mathrm{ft}^{2}\left[9^{\prime}\right]$ \\
\hline & Computer Lab & $960 \mathrm{ft}^{2}\left[9^{\prime}\right]$ \\
\hline & Restroom & $384 \mathrm{ft}^{2}\left[9^{\prime}\right]$ \\
\hline & Library & $1920 \mathrm{ft}^{2}\left[9^{\prime}\right]$ \\
\hline \multicolumn{3}{|c|}{ Roof Construction } \\
\hline & Built-Up W/ Grey Mineral Capsheet & Pre-retrofit \\
\hline & White Pvc Single-Ply Membrane & Post-retrofit \\
\hline & Wood Deck & Low-slope \\
\hline & R-30 Insulation & \\
\hline & Plenum & \\
\hline & $\begin{array}{l}\text { Dropped T-Bar Ceiling With } 3 / 4 \text { " Acoustical } \\
\text { Tile }\end{array}$ & \\
\hline \multicolumn{3}{|c|}{$\begin{array}{l}\text { Roof Solar } \\
\text { Reflectance }\end{array}$} \\
\hline & Pre-Retrofit & 0.25 \\
\hline & Post-Retrofit (Initial) & 0.79 \\
\hline & Post-Retrofit (2 Months) & 0.65 \\
\hline \multicolumn{3}{|c|}{ Roof Thermal } \\
\hline
\end{tabular}




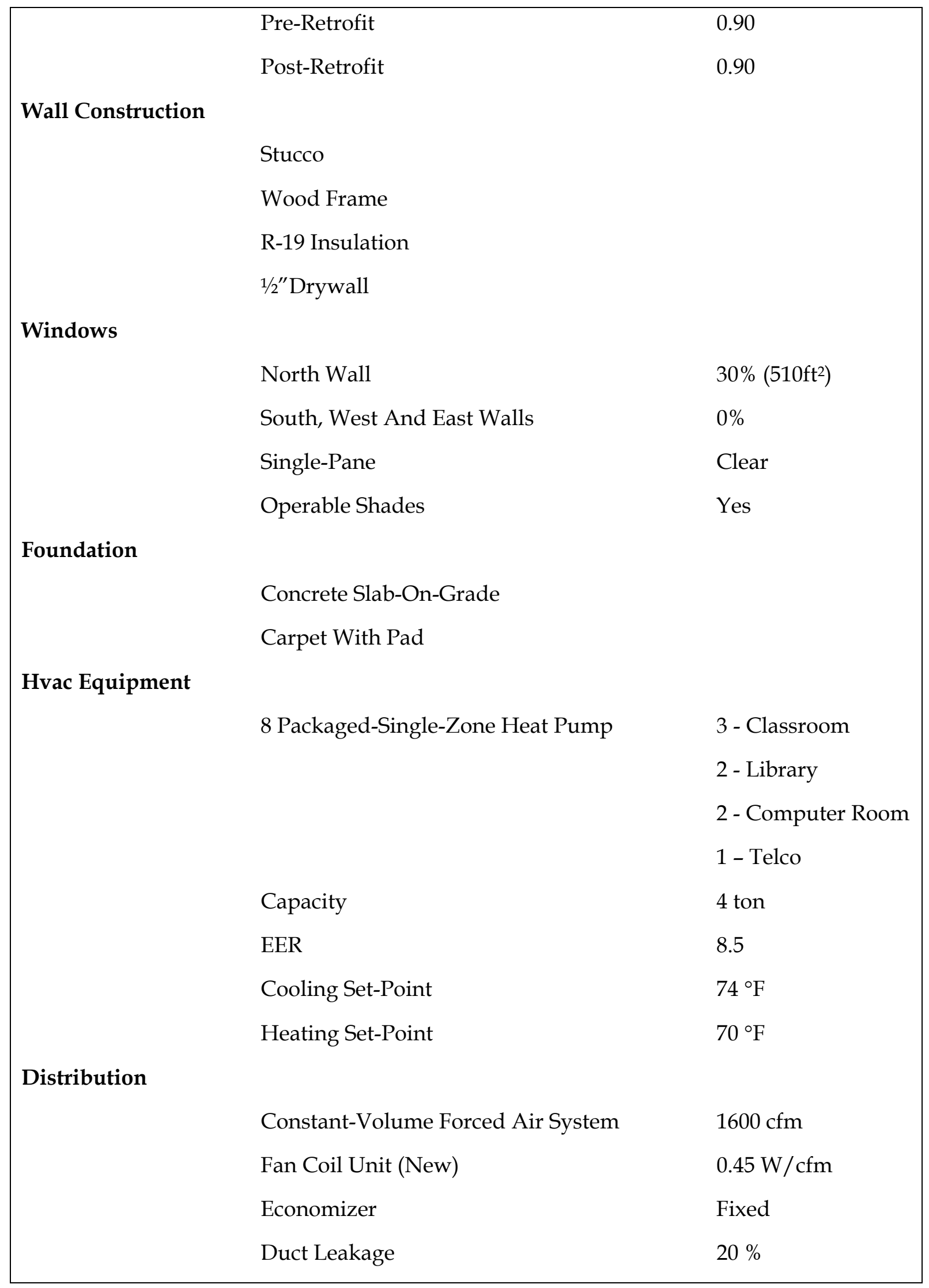




\begin{tabular}{|c|c|}
\hline Duct Temperature Drop & $2{ }^{\circ} \mathrm{F}$ \\
\hline Outside Air & 450 Cfm/System \\
\hline \multicolumn{2}{|c|}{ Schedule } \\
\hline Weekday Operation & $8 a m-5 p m$ \\
\hline \multicolumn{2}{|c|}{ Interior Load } \\
\hline Infiltration Air & $0.5 \mathrm{ACH}$ \\
\hline Lighting (New) & $1.5 \mathrm{~W} / \mathrm{ft}^{2}$ \\
\hline Classroom & \\
\hline Equipment & $0.5 \mathrm{~W} / \mathrm{ft}^{2}$ \\
\hline Occupants & 30 \\
\hline Computer Lab & \\
\hline Equipment & $\begin{array}{l}\text { Combine with light } \\
3.0 \mathrm{~W} / \mathrm{ft}^{2}\end{array}$ \\
\hline Occupants & 20 \\
\hline Library & \\
\hline Equipment & $0.5 \mathrm{~W} / \mathrm{ft}^{2}$ \\
\hline Occupants & 20 \\
\hline Restroom & \\
\hline Occupants & 1 \\
\hline
\end{tabular}


Prior to installation of cool roofs, the roof was covered with a gray mineral cap sheet and had a reflectance of 0.25 . A white PVC single-ply membrane roof was installed at the end of July, 2002. The initial reflectance of the PVC membrane was 0.79 dropping to about 0.65 in two months. The thermal emittance of these materials for both the mineral capsheet and the PVC membrane is 0.9 .

The operating schedule and the non-AC electricity use of the building were identified from the measured data. During the summer the school has a very irregular operational schedule. For our simulations, we assumed an 8 am to 5pm schedule, Monday through Fridays (excluding holidays). The installed interior lighting intensity was measured at $1.5 \mathrm{~W} / \mathrm{ft}^{2}$ and the equipment intensity was $0.5 \mathrm{~W} / \mathrm{ft}^{2}$ in classrooms and library and $1.5 \mathrm{~W} / \mathrm{ft}^{2}$ in the computer laboratory. Daytime peak non-AC electricity use was about $13 \mathrm{~kW}$ or $0.75 \mathrm{~W} / \mathrm{ft}^{2}$.

The building was modeled with eight 4-ton packaged single-zone heat pumps (one for each classroom, 2 for the library, 2 for the computer lab, and one for the telco room). All systems are constant volume cooling and gas heating units. The operating Energy Efficiency Ratio (EER) of the cooling equipment was calculated from the monitored data and nameplate capacity as 8.5. The cooling and heating setpoints are $74^{\circ} \mathrm{F}$ and $70^{\circ} \mathrm{F}$, respectively.

\section{Calibrated Simulations}

Annual cooling and heating energy use and peak power demand were simulated on an hourly time step with the DOE-2.1E building energy simulation program (BESG, 1990 and 1993) using California CTZ weather data for climate zone 10 (see Figure 1; San Marcos is located in California climate zone 10). Simulations were performed for both the dark and cool roof scenarios. In DOE-2 the ABSORPTANCE keyword for roof construction was 0.75 for the dark roof and 0.35 for the cool roof. In these simulations, we used both the measured daily and hourly data to calibrate the simulations. We used measured outdoor temperature to adjust the simulated cooling energy use that was based on the CTZ weather data. We were able to calibrate the simulated average daily energy savings data within about $12 \%$ of the measured cooling energy savings. Our effort to calibrate simulated hourly consumption was not as successful. The summary results for these calibrated simulations are presented in Table 21.

Table 21 shows the simulated cooling electricity savings and compares them with measured savings data. The simulated average daily savings is $21 \mathrm{kWh}$ as compared to the measured savings of $23 \mathrm{kWh}$ (a difference of about 12\%). The hourly simulated peak demand data are from $-48 \%$ to $+92 \%$ different from the measured data (excluding the out-of-range data for Hour 16). The simulated average peak demand savings for hour $12-17$ is $1.8 \mathrm{~kW}$ compared to measured savings of $2.1 \mathrm{~kW}$ (a difference of $-15 \%$ ). The simulated average peak demand savings is $1.9 \mathrm{~kW}$ compared to measured savings of $2.8 \mathrm{~kW}$ when the outside temperature is $85^{\circ} \mathrm{F}$ (a difference of $-31 \%$ ). We defined adjustment factors as the ratio of measured to simulated values. These adjustment factors will be used to adjust the simulated savings for other California climate zones.

\section{Estimated Savings for Other California Climate Zones}

We used the calibrated DOE-2 model and simulated the energy use for other climate regions, using California CTZ weather data in each of the 16 climate zones (see Figure 1) and for dark and cool roof scenarios. All input variables were kept constant as the calibrated model. Table 22 
summarizes the results of these simulations. All savings estimates are normalized per $1000 \mathrm{ft}^{2}$ of conditioned roof area. The simulated savings are scaled using the adjustment factor of 1.12 as shown in Table 21.

Table 21. Richland Elementary School in San Marcos: Measured and simulated cooling electricity savings and adjustment factors. ${ }^{a}$

\begin{tabular}{|l|c|c|c|c|}
\hline Period & $\begin{array}{c}\text { Measured average } \\
\text { temperature }\left({ }^{\circ} \mathrm{F}\right)\end{array}$ & $\begin{array}{c}\text { Simulated } \\
\text { Savings }\end{array}$ & $\begin{array}{c}\text { Measured } \\
\text { Savings }\end{array}$ & $\begin{array}{c}\text { Adjustment } \\
\text { Factor }\end{array}$ \\
\hline Hour 12 & 80.5 & $1.9 \mathrm{~kW}$ & $1.5 \mathrm{~kW}$ & 0.83 \\
\hline Hour 13 & 81.7 & $1.9 \mathrm{~kW}$ & $2.3 \mathrm{~kW}$ & 1.22 \\
\hline Hour 14 & 81.9 & $1.7 \mathrm{~kW}$ & $0.9 \mathrm{~kW}$ & 0.52 \\
\hline Hour 15 & 81.7 & $1.7 \mathrm{~kW}$ & $3.4 \mathrm{~kW}$ & 1.97 \\
\hline Hour 16 & 80.7 & $1.8 \mathrm{~kW}$ & $7.3(?) \mathrm{kW}$ & $4.09(?)$ \\
\hline Hour 17 & 79.5 & $1.7 \mathrm{~kW}$ & $2.2 \mathrm{~kW}$ & 1.30 \\
\hline Average hours 12-17 & 81.0 & $1.8 \mathrm{~kW}$ & $2.1 \mathrm{~kW}$ & 1.15 \\
\hline Hour when $\mathrm{T}_{\text {out }}=85^{\circ} \mathrm{F}$ & 85.0 & $1.9 \mathrm{~kW}$ & $2.8 \mathrm{~kW}$ & 1.45 \\
\hline $\begin{array}{l}\text { Average daily energy } \\
\text { savings }\end{array}$ & 71.7 & $20.6 \mathrm{kWh}$ & $23.0 \mathrm{kWh}$ & 1.12 \\
\hline
\end{tabular}

Notes:

a. The simulated average daily savings is $21 \mathrm{kWh}$ (compared to measured savings of $23 \mathrm{kWh}$ ). The simulated average peak demand savings for hour 12-17 is $1.8 \mathrm{~kW}$ (compared to measured savings of $2.8 \mathrm{~kW}$ ). The simulated average peak demand savings is $1.9 \mathrm{~kW}$ (compared to measured savings of $2.8 \mathrm{~kW}$ ) when the outside temperature is $85^{\circ} \mathrm{F}$. The adjustment factors are the ratio of measured to simulated values.

b. Daily energy savings averaged over the monitoring period (Pre and Post). 
Table 22 shows that in a new building application in climate Zones 2-16, installing a cool roof on a building similar to this school can save about 300-600 kWh per year per $1000 \mathrm{ft}^{2}$ of conditioned roof area. The annual savings in climate zone 1 are less than $100 \mathrm{kWh}$.

Table 23 shows the estimates of peak demand savings for all 16 climate zones. The savings are estimated for an average hour between hours 12 to 17 and for the period of June 1 to September 30 . For an average condition, the application of cool roofs will yield an estimates peak demand savings of about $0.24-0.35 \mathrm{~W} / \mathrm{ft}^{2}$, for all 16 climate zones. During extreme summer peak conditions, the estimated peak demand savings can reach $0.5 \mathrm{~W} / \mathrm{ft}^{2}$.

Assuming an average cost of $\$ 0.10 / \mathrm{kWh}$, in climate Zones 2-16, the estimates of energy savings range from $0.03-0.06 \$ / \mathrm{ft}^{2}\left(0.3-0.6 \$ / \mathrm{m}^{2}\right)$. The average summertime peak-demand savings range from 0.24 to $0.35 \mathrm{~W} / \mathrm{ft}^{2}\left(2.2-3.5 \mathrm{~W} / \mathrm{m}^{2}\right)$. Assuming a monthly peak-demand charge of $\$ 20 / \mathrm{kW}$, the estimated May-October peak-demand savings is $[6$ (month) $] \times[\$ 20 / \mathrm{kW} /($ month $)] \times[0.24-$ $\left.0.35 \mathrm{~W} / \mathrm{ft}^{2}\right] \times[1 / 1000 \mathrm{~kW} / \mathrm{W}]=0.024-0.04 \$ / \mathrm{ft}^{2}\left(0.26-0.42 \$ / \mathrm{m}^{2}\right)$. The total annual savings (energy and peak demand reduction) ranges from 0.06 to $0.10 \$ / \mathrm{ft}^{2}\left(0.6\right.$ to $\left.1.0 \$ / \mathrm{m}^{2}\right)$. 
Table 22. Richland Elementary School in San Marcos: Estimated annual energy savings of buildings with similar characteristics in other California Climate Zones.

\begin{tabular}{|c|c|c|c|c|c|}
\hline \multirow{2}{*}{ CTZ } & \multirow{2}{*}{$\begin{array}{l}\text { Base use } \\
\text { (kWh/year) }\end{array}$} & \multicolumn{2}{|c|}{ Simulated savings } & \multicolumn{2}{|c|}{ Adjusted savings } \\
\hline & & (kWh) & $\%$ & $(\mathrm{kWh})$ & $\%$ \\
\hline 1 & 2651 & 89 & 3.3 & 99 & 3.7 \\
\hline 2 & 5223 & 389 & 7.5 & 436 & 8.3 \\
\hline 3 & 2912 & 338 & 11.6 & 378 & 13.0 \\
\hline 4 & 4071 & 467 & 11.5 & 523 & 12.8 \\
\hline 5 & 2792 & 283 & 10.1 & 317 & 11.3 \\
\hline 6 & 4232 & 472 & 11.1 & 528 & 12.5 \\
\hline 7 & 3666 & 477 & 13.0 & 535 & 14.6 \\
\hline 8 & 4263 & 571 & 13.4 & 639 & 15.0 \\
\hline 9 & 4530 & 500 & 11.0 & 560 & 12.4 \\
\hline 10 & 5310 & 542 & 10.2 & 607 & 11.4 \\
\hline 11 & 6700 & 424 & 6.3 & 475 & 7.1 \\
\hline 12 & 5214 & 431 & 8.3 & 483 & 9.3 \\
\hline 13 & 6119 & 489 & 8.0 & 548 & 9.0 \\
\hline 14 & 7062 & 418 & 5.9 & 469 & 6.6 \\
\hline 15 & 8758 & 595 & 6.8 & 666 & 7.6 \\
\hline 16 & 5340 & 234 & 4.4 & 262 & 4.9 \\
\hline
\end{tabular}

Notes: All estimates are normalized per $1000 \mathrm{ft}^{2}$ of conditioned roof area. The "basecase" includes both cooling-and heating-energy use. The "savings" are net (cooling savings - heating penalties) annual savings. 
Table 23. Richland Elementary School in San Marcos: Estimated peak demand savings of buildings with similar characteristics in other California Climate Zones.

\begin{tabular}{|c|c|c|}
\hline CTZ & Simulated Savings $\left(\mathrm{W} / \mathrm{ft}^{2}\right)$ & Adjusted Savings $\left(\mathrm{W} / \mathrm{ft}^{2}\right)$ \\
\hline 1 & 0.21 & 0.24 \\
\hline 2 & 0.31 & 0.36 \\
\hline 3 & 0.27 & 0.33 \\
\hline 4 & 0.29 & 0.30 \\
\hline 5 & 0.26 & 0.26 \\
\hline 6 & 0.23 & 0.25 \\
\hline 7 & 0.22 & 0.32 \\
\hline 8 & 0.28 & 0.31 \\
\hline 9 & 0.27 & 0.35 \\
\hline 10 & 0.31 & 0.33 \\
\hline 11 & 0.28 & 0.34 \\
\hline 12 & 0.30 & 0.35 \\
\hline 13 & 0.31 & 0.30 \\
\hline 14 & 0.26 & 0.32 \\
\hline 15 & 0.28 & 0.32 \\
\hline
\end{tabular}

Notes: The peak demand savings are average estimates for hours 12-17 from June 1 to September 30. All estimates are normalized per $\mathrm{ft}^{2}$ of conditioned roof area. 


\subsubsection{Fruit Packing/Cold Storage Facility in Reedley}

\subsubsection{Building Description}

Kaprielian Brothers Packing Company is an industrial cold storage facility located in Reedley, 15 miles south of Fresno. The complex has approximately 100,000 ft² of high-bay warehouse consisting of cold storage, packing, and conditioning rooms that process, pack, and store stone fruit such as peaches and plums. Building characteristics are summarized in Table 24 and a plan of the buildings is provided in Figure 31.

Table 24. Kaprielian Brothers Packing Company (Cold Storage) Facility in Reedley: Building characteristics.

\begin{tabular}{l|lllll}
\hline Room & $\begin{array}{l}\text { Floor } \\
\text { Area } \\
\left(\mathrm{ft}^{2}\right)\end{array}$ & Roof & $\begin{array}{l}\text { Temperature } \\
\left({ }^{\circ} \mathrm{F}\right)\end{array}$ & $\begin{array}{l}\text { Ceiling } \\
\text { R-value }\end{array}$ & $\begin{array}{l}\text { Wall } \\
\text { R-value }\end{array}$ \\
\hline Cold Storage \#1-7 & 44,348 & Back EPDM & 32 & 30 foam & - \\
Hallway & 8,293 & Back EPDM & unconditioned & 30 foam & - \\
Conditioning & 5,904 & Bare Metal & $32-68$ & 11 batt & 11 batt \\
Palletizing & 7,974 & Bare Metal & 60 & 11 batt & 11 batt \\
Packing \#1 & 23,710 & Bare Metal & 70 & 11 batt & 11 batt \\
Packing \#2 & 4,932 & Bare Metal & unconditioned & 11 batt & 11 batt \\
Packing \#3 & 7,622 & Bare Metal & unconditioned & 11 batt & 11 batt \\
Cold Storage \#11-12 & 8,350 & Bare Metal & 32 & 30 foam & 30 foam \\
\hline
\end{tabular}

The packing plant buildings can be separated into four distinct environments: pre-conditioning, packing, post-conditioning, and storage. Fresh fruit is initially cooled to $32^{\circ} \mathrm{F}$ with a hydrocooler and then either "tunneled" in cold storage rooms 11 and 12, or brought directly into packing room 1. After the fruit is packed, the boxes are loaded onto pallets in the palletizing room and then either conditioned in the conditioning room or placed directly in cold storage rooms 1-7.

A central ammonia chiller complex cools the conditioning room, cold storage rooms, and hydrocooler. Four roof-top package units cool packing room \#1. The hallway next to cold storage and packing rooms 2 and 3 are not directly conditioned but the hallway stays at $\sim 50^{\circ} \mathrm{F}$ due to its close connection to the cold storage rooms. The packing plant has two electrical transformers: T1, which serves the chillers and the cold storage rooms 1-7, and T2, which serves the remaining areas. 


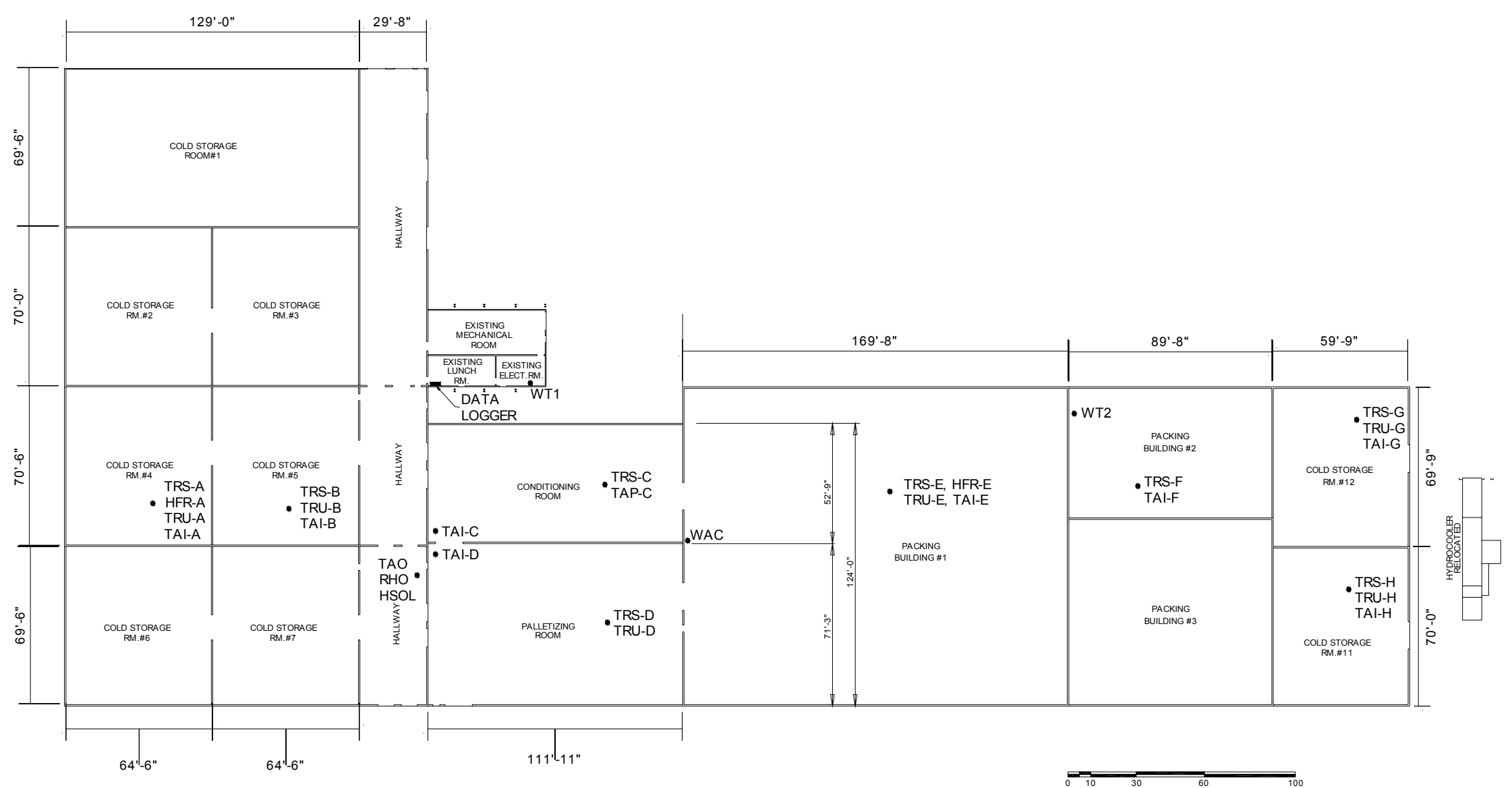

Figure 31. Kaprielian Brothers Packing Company (Cold Storage) Facility in Reedley: Building monitoring point locations. 


\subsubsection{Instrumentation and Data Acquisition Systems}

Monitoring data were collected for approximately one month before and after coating of the roof. Parameters that were measured to assess cool roof performance include:

- Roof surface temperatures

- Roof underside temperatures

- Conducted heat flux through roofs

- Indoor air temperatures

- Weather conditions

- Building energy use.

Table 25 summarizes the monitoring points and Figure 31 shows their locations. In Figure 32, we show outside views of the cold-storage and packing buildings, the roofs of the cold storage and packing buildings, and the interior of cold storage room 4 and packing room 1.

Initial and post retrofit roof albedos were measured for the cold storage building EPDM membrane and the packing building galvalum room using ASTM E1918 - Standard Test Method for Measuring Solar Reflectance of Horizontal and Low-Sloped Surfaces in the Field (see Table 26). Views of the coated roof are shown in Figure 33.

\subsubsection{Air Conditioning Systems and Building Operation Schedules}

A central ammonia chiller complex cools the conditioning room, cold storage rooms, and hydrocooler. Four roof-top package units cool packing room 1. The operation is of the chiller and AC systems are highly seasonal. During the peak periods (June through August), the facilities operate 24 hours, typically six days a weeks.

\subsubsection{Data Acquisition Approach}

All sensors were continuously scanned and were summed or averaged in datalogger memory every 15 minutes. The datalogger had battery backup to protect against data loss during power outages. Data were downloaded weekly and all data ranges were immediately reviewed. Outof-range data were reported and investigated to determine whether a sensor or monitoring error existed or equipment had failed. Data were collected by Davis Energy Group and files were transferred to LBNL weekly during the monitoring period.

\subsubsection{Datalogger and Sensor Specifications}

\section{Datalogger}

A Data Electronics DT500 datalogger mounted in a NEMA 1 box was installed in the telephone equipment room next to the mechanical room (see Figure 34). The datalogger was provided with an RS232 communications interface, modem, and battery backup. The existing Alerton EMCS phone line was originally going to be shared using a telephone line sharing switch, but 
due to the critical need for access to the EMCS for alarm purposes the line was manually switched over once per week to download data.

Table 25. Kaprielian Brothers Packing Company (Cold Storage) Facility in Reedley: Building monitoring points

\begin{tabular}{l|lll}
\hline No. & Name & Location & Purpose \\
\hline 1 & TRS-A & Cold Storage \#4 & Roof surface temperature \\
2 & HFR-A & Cold Storage \#4 & Roof heat flux \\
3 & TRU-A & Cold Storage \#4 & Roof underside temperature \\
4 & TAI-A & Cold Storage \#4 & Interior air temperature \\
5 & TRS-B & Cold Storage \#5 & Roof surface temperature \\
6 & TRU-B & Cold Storage \#5 & Roof underside temperature \\
7 & TAI-B & Cold Storage \#5 & Interior air temperature \\
8 & TRS-C & Conditioning Room & Roof surface temperature \\
9 & TAP-C & Conditioning Room & Plenum air temperature \\
10 & TAI-C & Conditioning Room & Interior air temperature \\
11 & TRS-D & Palletizing Room & Roof surface temperature \\
12 & TRU-D & Palletizing Room & Roof underside temperature \\
13 & TAI-D & Palletizing Room & Interior air temperature \\
14 & TRS-E & Packing \#1 & Roof surface temperature \\
15 & HFR-E & Packing \#1 & Roof heat flux \\
16 & TRU-E & Packing \#1 & Roof underside temperature \\
17 & TAI-E & Packing \#1 & Interior air temperature \\
18 & TRU-F & Packing \#2 & Roof underside temperature \\
19 & TAI-F & Packing \#2 & Interior air temperature \\
20 & TRS-G & Cold Storage \#12 & Roof surface temperature \\
21 & TRU-G & Cold Storage \#12 & Roof underside temperature \\
22 & TAI-G & Cold Storage \#12 & Interior air temperature \\
23 & TRS-H & Cold Storage \#11 & Roof surface temperature \\
24 & TRU-H & Cold Storage \#11 & Roof underside temperature \\
25 & TAI-H & Cold Storage \#11 & Interior air temperature \\
26 & TAO & Palletizing Roof & Outdoor air temperature \\
27 & RHO & Palletizing Roof & Outdoor relative humidity \\
28 & HSOL & Palletizing Roof & Horizontal solar radiation \\
29 & WAC & Packing sub-panel & Total packing A/C electricity use \\
30 & WT1 & Transformer 1 main panel & Total chiller electricity use \\
31 & WT2 & Transformer 2 main panel & Total building electricity use \\
\hline & & & \\
\hline
\end{tabular}




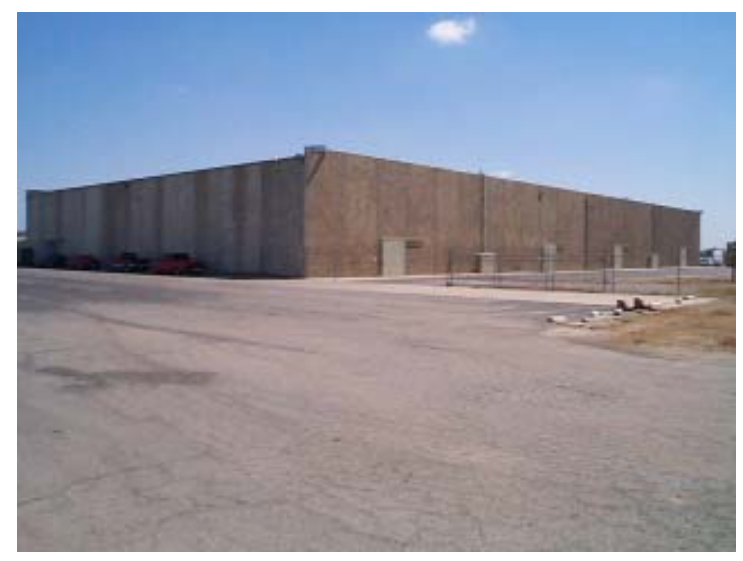

(a)

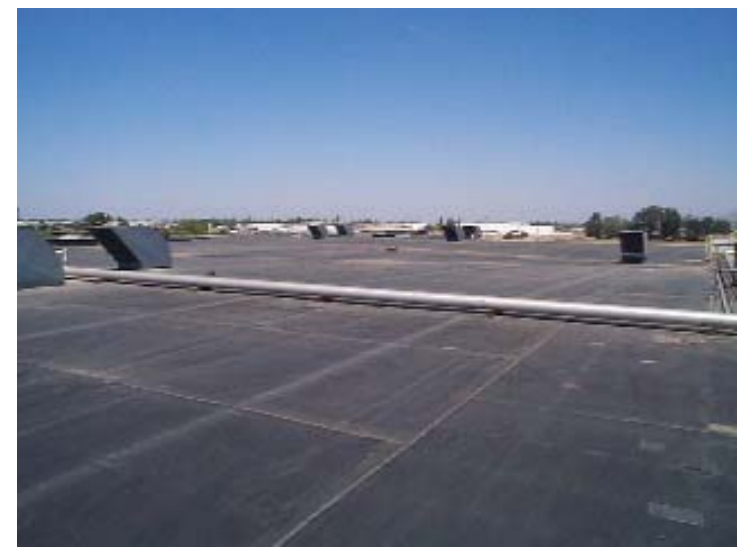

(c)

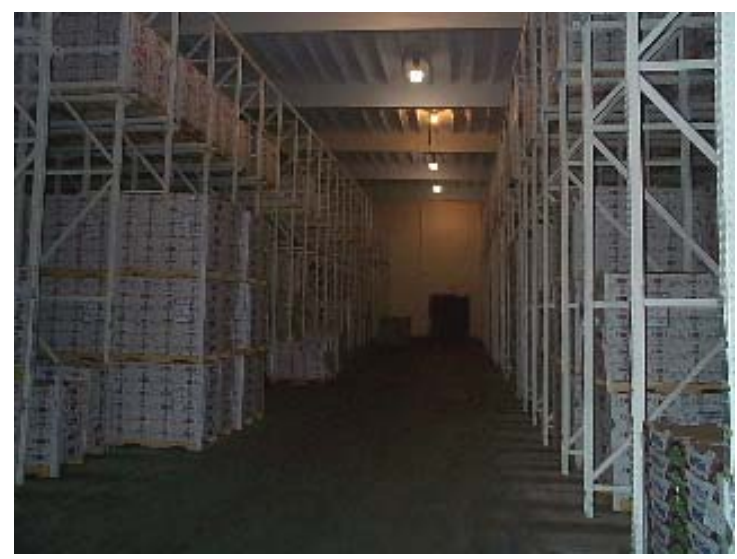

(e)

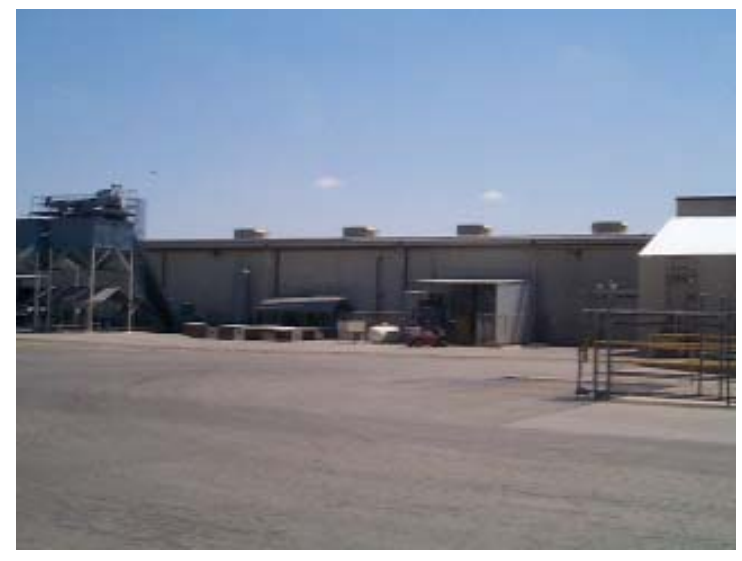

(b)

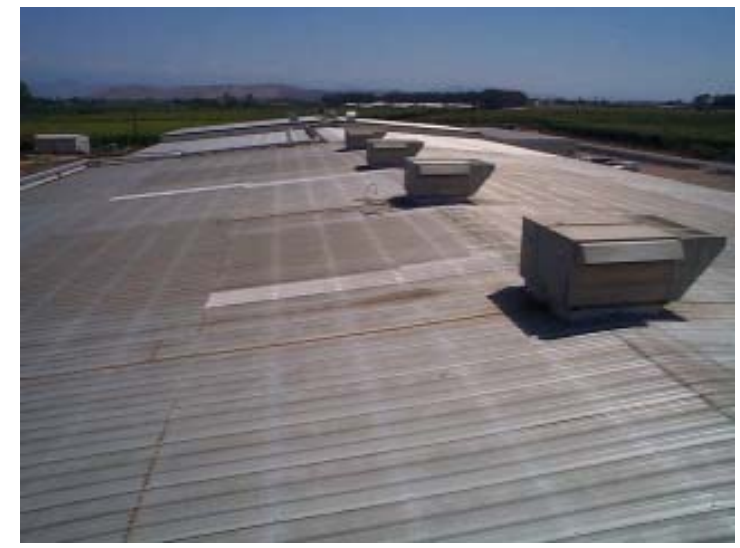

(d)

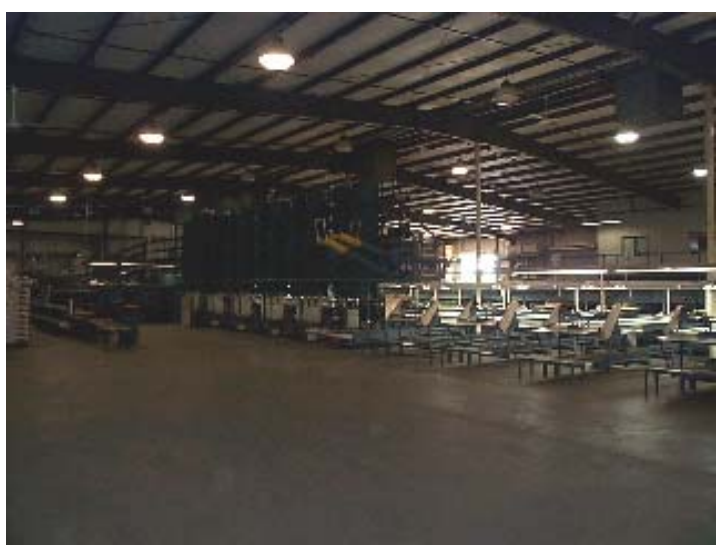

(f)

Figure 32. Kaprielian Brothers Packing Company (Cold Storage) Facility in Reedley: (a) cold storage building; (b) packing building; (c) cold storage building roof; (d) packing building roof; (e) cold storage room \#4; and (f) packing room \#1. 
Table 26. Kaprielian Brothers Packing Company (Cold Storage) Facility in Reedley: Roof albedo measurements.

\begin{tabular}{|c|c|c|c|c|c|c|}
\hline \multirow[b]{2}{*}{ Location } & \multirow[b]{2}{*}{ Notes } & & \multicolumn{3}{|c|}{ Measurement } & \multirow[b]{2}{*}{ Average } \\
\hline & & & 1 & 2 & 3 & \\
\hline \multicolumn{7}{|l|}{ Pre } \\
\hline \multirow[t]{3}{*}{1} & \multirow{3}{*}{$\begin{array}{l}\text { Cold storage EPDM } \\
\text { 4/16/2002 12:30 } \\
\text { Clear, calm }\end{array}$} & $U p\left(\mathrm{~W} / \mathrm{m}^{2}\right)$ & 881 & 893 & 892 & 889 \\
\hline & & Down $\left(\mathrm{W} / \mathrm{m}^{2}\right)$ & 32 & 35 & 38 & 35 \\
\hline & & Albedo & $4 \%$ & $4 \%$ & $4 \%$ & $4 \%$ \\
\hline \multirow[t]{3}{*}{2} & \multirow[t]{3}{*}{ Packing house metal } & $U p\left(\mathrm{~W} / \mathrm{m}^{2}\right)$ & 920 & 925 & 927 & 924 \\
\hline & & Down $\left(\mathrm{W} / \mathrm{m}^{2}\right)$ & 281 & 282 & 281 & 281 \\
\hline & & Albedo & $31 \%$ & $30 \%$ & $30 \%$ & $30 \%$ \\
\hline \multicolumn{7}{|l|}{ Post } \\
\hline \multirow[t]{3}{*}{3} & \multirow{3}{*}{$\begin{array}{l}\text { Coated EPDM } \\
6 / 11 / 2003 \text { 12:25 } \\
\text { Clear, light breeze }\end{array}$} & $U p\left(\mathrm{~W} / \mathrm{m}^{2}\right)$ & 918 & 913 & 908 & 913 \\
\hline & & Down $\left(\mathrm{W} / \mathrm{m}^{2}\right)$ & 598 & 588 & 584 & 590 \\
\hline & & Albedo & $65 \%$ & $64 \%$ & $64 \%$ & $65 \%$ \\
\hline \multirow[t]{3}{*}{4} & \multirow[t]{3}{*}{ Coated metal } & $U p\left(\mathrm{~W} / \mathrm{m}^{2}\right)$ & 891 & 889 & 888 & 889 \\
\hline & & Down & 560 & 557 & 557 & 558 \\
\hline & & Albedo & $63 \%$ & $63 \%$ & $63 \%$ & $63 \%$ \\
\hline \multicolumn{7}{|c|}{ Decommission } \\
\hline \multirow[t]{3}{*}{5} & \multirow{3}{*}{$\begin{array}{l}\text { Coated EPDM } \\
\text { 2/5/2004 2:10 } \\
\text { High cirrus, breezy }\end{array}$} & $U p\left(\mathrm{~W} / \mathrm{m}^{2}\right)$ & 555 & 550 & 555 & 553 \\
\hline & & Down $\left(\mathrm{W} / \mathrm{m}^{2}\right)$ & 373 & 387 & 385 & 382 \\
\hline & & Albedo & $67 \%$ & $70 \%$ & $69 \%$ & $69 \%$ \\
\hline \multirow[t]{3}{*}{6} & \multirow[t]{3}{*}{ Coated metal } & $U p\left(\mathrm{~W} / \mathrm{m}^{2}\right)$ & 725 & 692 & 630 & 682 \\
\hline & & Down $\left(\mathrm{W} / \mathrm{m}^{2}\right)$ & 513 & 476 & 440 & 476 \\
\hline & & Albedo & $71 \%$ & $69 \%$ & $70 \%$ & $70 \%$ \\
\hline
\end{tabular}




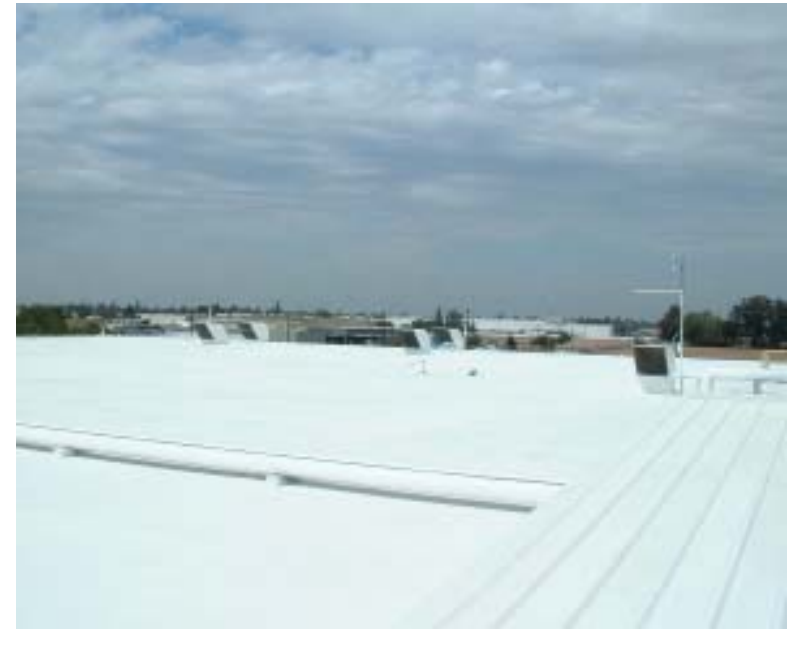

(a)

Figure 33. Kaprielian Brothers Packing Company (Cold Storage) Facility in Reedley: (a) coated cold storage roof, and (b) coated packing roof.

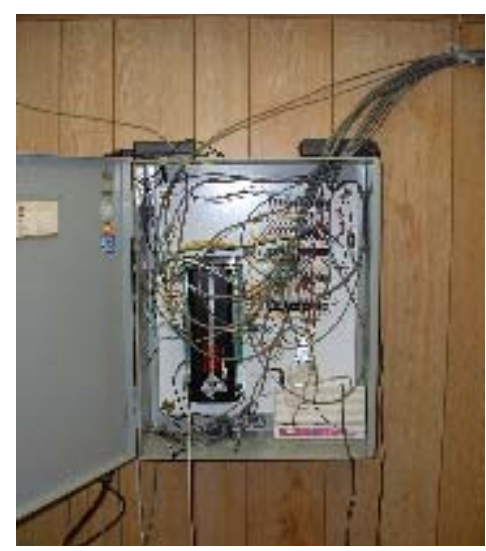

Figure 34. Kaprielian Brothers Packing Company (Cold Storage) Facility in Reedley: Data logger box. 


\section{Surface Temperatures}

Roof surface temperatures were measured with Minco RTD thermal ribbon sensors (see Figure 35a). The cold storage EPDM roof temperatures (A\&B) were measured by placing the sensor under the membrane through a slit. The metal roof surface temperatures $(\mathrm{C}-\mathrm{H})$ were measured by attaching the sensor to the underside of the metal pan. The sensors were connected to the data logger with 4-20 ma current transducers. Underside surface temperatures were measured on the underside of the insulation (see Figure 35b).

\section{Roof Heat Flux}

Roof surface heat flux was measured with Hukseflux HFP01 thermopile heat flux sensors (see Figure 35c). One was placed under the cold storage building EPDM membrane (location A) and one was attached to the underside of the packing building metal roof (location $\mathrm{E}$ ).

\section{Air Temperatures}

Building interior temperatures were measured with shielded AD592 semiconductor sensors suspended three feet below the ceiling level (see Figure 35d). The air temperature in the plenum space between the conditioning room and the roof was also measured.

\section{Weather Tower}

Outdoor dry-bulb air temperature and relative humidity were measured with an R.M. Young $\mathrm{RH} /$ temperature probe mounted in a Gill multi-plate radiation shield and attached to a weather tower mast located on the roof between the packing building and the storage building (see Figure 36). Total horizontal solar insolation was measured with a Li-Cor LI-200SZ silicon photodetector.

\section{Power}

All building power is 480VAC, three phase and three wire (commonly called Delta). Building power was measured with Continental Control Systems 3D-480-P WattNode power transducer and Magnelab current transformers (CTs). The roof-top package units (RTUs) were submetered at their sub-panels using 100A split-core CTs. Transformer 1 and 2 powers were measured at the service entrance bus bars using 3000A bus-bar CTs (see Figure 37).

\subsubsection{Monitoring Period}

The instrumentation was installed on June 19-20, 2002. The system was debugged and data were calibrated during the period June 21-27, 2002. The pre-retrofit (Pre) data cover the period of June 28, 2002 to August 18, 2002 (51 days). The roof was coated during August 19 to August 22, 2002. The post-retrofit (Post) data cover the period of August 23 to September 30, 2002 (38 days) and June 1 to September 30, 2003. 


\subsubsection{Data Analysis and Results}

The first step in the analysis was to aggregate the validated 15-minute data into hourly and daily data. This was done for solar intensity, cooling electricity use, and total building electricity use. The temperature data were averaged to yield hourly and daily variables. In this process, questionable and missing data were identified and excluded from the analysis.

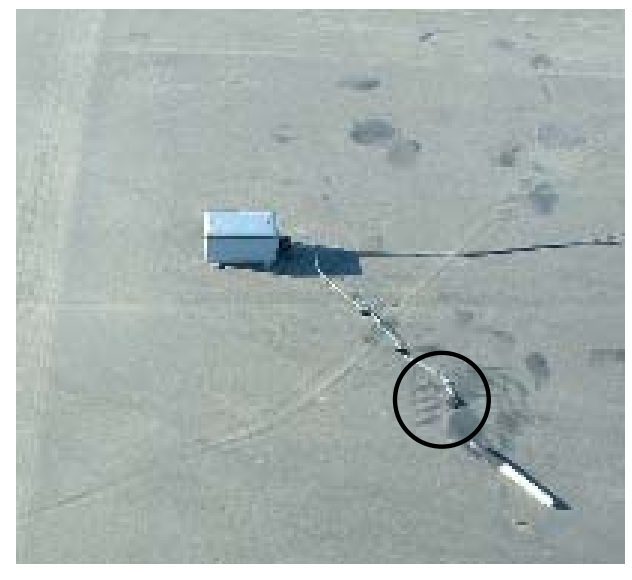

(a)

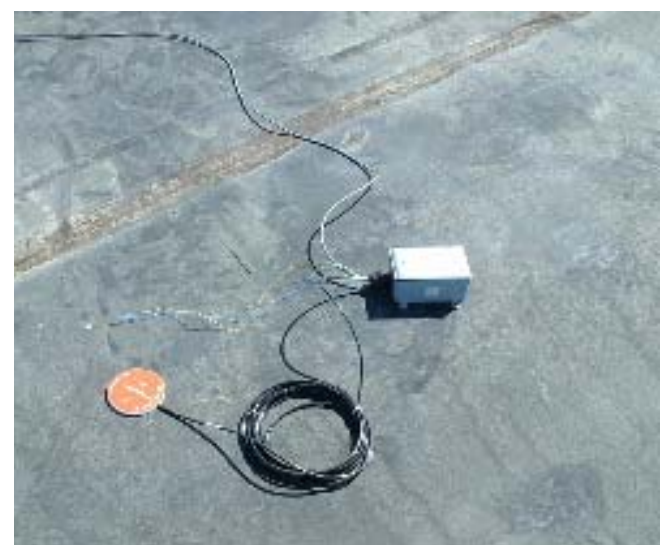

(c)

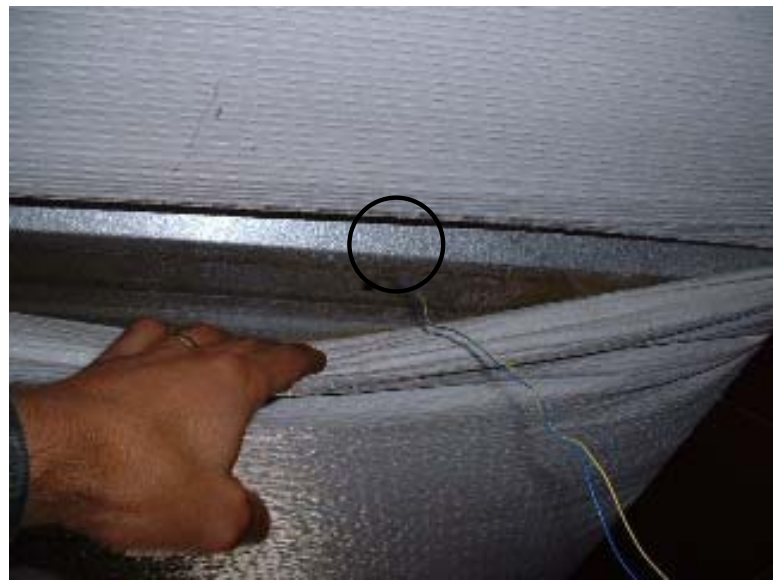

(b)

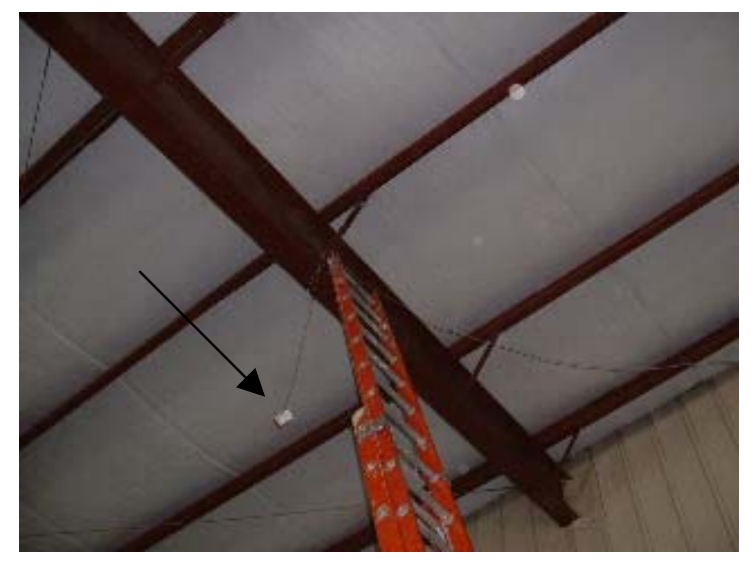

(d)

Figure 35. Kaprielian Brothers Packing Company (Cold Storage) Facility in Reedley: (a) EPDM surface temperature sensor, (b) galvalum surface temperature sensor, (c) heat flux sensor, and (d) interior air temperature sensor. 


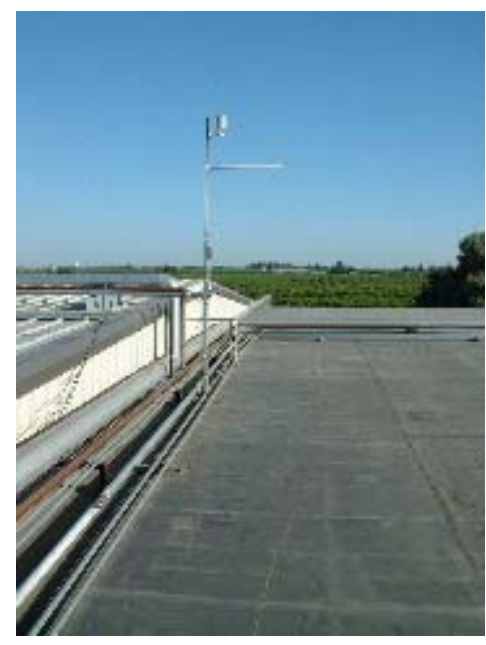

Figure 36. Kaprielian Brothers Packing Company (Cold Storage) Facility in Reedley: Weather tower
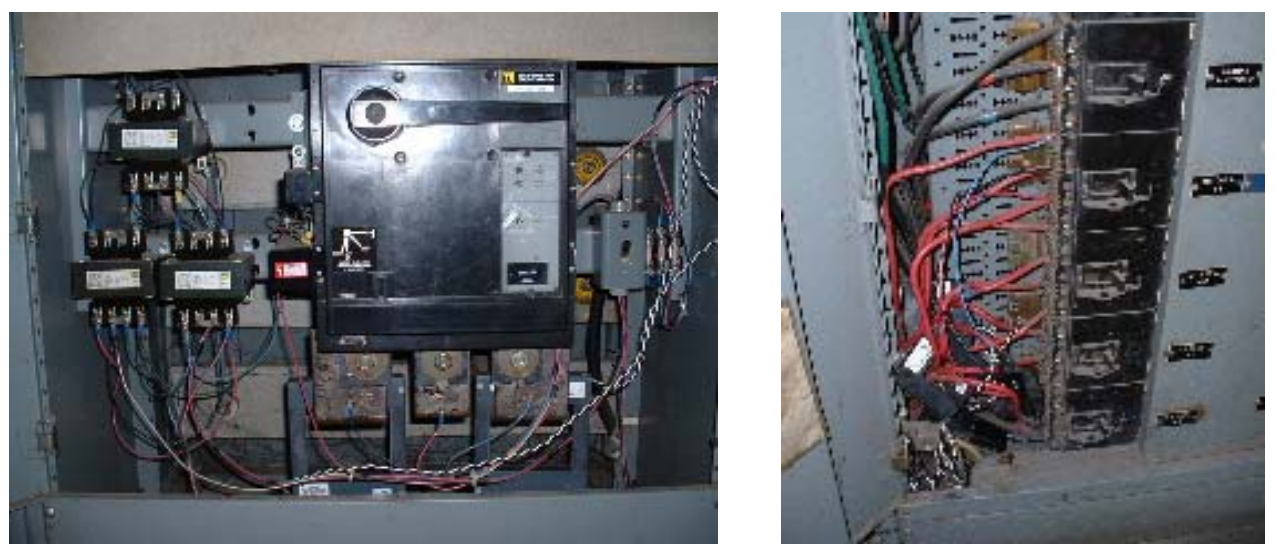

(a)

(b)

Figure 37. Kaprielian Brothers Packing Company (Cold Storage) Facility in Reedley: Metering panels (a) T2 panel current transducer installation, and (b) $\mathrm{A} / \mathrm{C}$ panel current transducer installation. 
The parameters that can affect air-conditioning electricity use include outside temperature, inside temperature, solar heat gain, internal loads, and relative humidity. A systematic regression analysis was performed in order to determine the sensitivity of the air-conditioning electricity use to these environmental parameters. The analysis was performed for the conditions before the roof was coated with a reflective white coating (defined as Pre period) and for the conditions after the roof was coated (defined as Post period). These regressions allowed normalizing the Pre and Post conditions for all parameters before making an attempt to estimate savings from the application of white coating.

\section{Temperature and Heat Flux Data}

Cold Storage Building (Areas 1-7). Figure 38 shows hourly temperature and conducted heat flux data for a period of two weeks before and three weeks after the roof was coated on August 19, 2002. In the Pre period, during the hot sunny days, the surface temperature at all monitored locations is about $70^{\circ} \mathrm{F}$ to $85^{\circ} \mathrm{F}$ warmer than the outdoor temperature. During the nights, the surface temperatures cool down to $20^{\circ} \mathrm{F}$ to $25^{\circ} \mathrm{F}$ below outdoor temperature. This is primarily because of radiation exchange to nighttime clear sky. For the Post period, during the days, the maximum surface temperature is only about $5^{\circ} \mathrm{F}$ to $10^{\circ} \mathrm{F}$ warmer than outdoor temperature. Hence, the reduction in surface temperature after the coating is about $65^{\circ} \mathrm{F}$ to $75^{\circ} \mathrm{F}$.

In the cold storage areas, the under-roof and inside temperatures closely follow each other at about $32^{\circ} \mathrm{F}$ to $35^{\circ} \mathrm{F}$, and the under-roof temperature is about $35^{\circ} \mathrm{F}$ to $37^{\circ} \mathrm{F}$. Also note the distinct daily sharp peak in the cold storage temperature that results from defrosting the evaporators.

The range of hourly conduction heat flux through the roof during a 24-hour period, at location ' $\mathrm{A}$ ', for the Pre period ranges from -5.6 to $11 \mathrm{~W} / \mathrm{ft}^{2}\left(-60\right.$ to $\left.120 \mathrm{~W} / \mathrm{m}^{2}\right)$ and for the Post period ranges from -1.4 to $4.2 \mathrm{~W} / \mathrm{ft}^{2}\left(-15\right.$ to $\left.45 \mathrm{~W} / \mathrm{m}^{2}\right)$, a drop of about $6 \mathrm{~W} / \mathrm{ft}^{2}$ during peak daytime. The reduction in the range is the direct consequence of inside surface temperature which is not varying significantly during the day. (Assuming an overall COP of 3 for the chiller, the reduction in chiller energy use is about $1 \mathrm{~W} / \mathrm{ft}^{2}$, and for the entire storage area of $66,600 \mathrm{ft}^{2} \mathrm{the}^{-}$ savings are about $67 \mathrm{~kW}$.)

Figure 39 shows the corresponding hourly temperatures averaged over the Pre and Post periods. The average outdoor hourly temperature for the Pre period is about $6^{\circ} \mathrm{F}$ warmer than that of the Post period. The average maximum insolation is about $84 \mathrm{~W} / \mathrm{ft}^{2}$ during Pre period and about $70 \mathrm{~W} / \mathrm{ft}^{2}$ during the Post period. The maximum surface temperature at locations ' $\mathrm{A}$ ' and ' $\mathrm{B}$ ' drop from $175^{\circ} \mathrm{F}-180^{\circ} \mathrm{F}$ to about $100^{\circ} \mathrm{F}$ after installation of reflective roof coating. The average conducted heat fluxes at location 'A' (see Figure 40) is similar to those discussed above. On the average, the maximum surface temperature was reduced by about $80^{\circ} \mathrm{F}$ after coating the roof. The minimum nighttime surface temperature for the Pre and Post periods can get about $20^{\circ} \mathrm{F}$ cooler than ambient air temperature. This is because of radiative nighttime cooling to the clear sky.

The under-roof temperatures and inside temperatures at locations ' $\mathrm{A}$ ' and ' $\mathrm{B}$ ' are very similar for the Pre and Post periods (see Figure 39). Averages of inside temperatures are fairly flat, ranging from $32^{\circ} \mathrm{F}$ to $35^{\circ} \mathrm{F}$. 

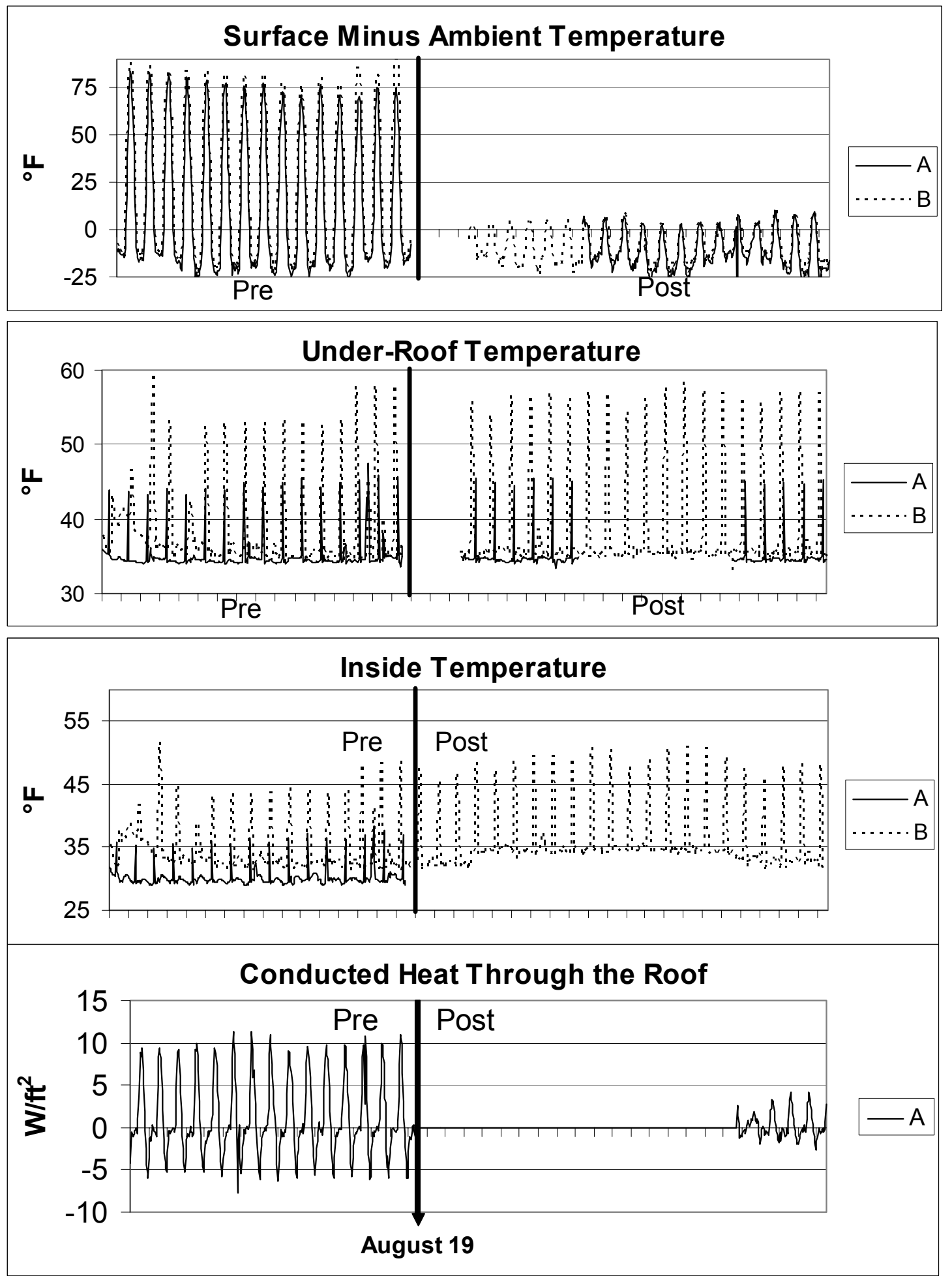

Figure 38. Kaprielian Brothers Packing Company (Cold Storage) Facility in Reedley: Hourly temperatures and conducted heat flux through the roof for two-week periods before and three weeks after installation of a reflective roof coating on August 19, 2002. 'A' and 'B' are measurements at two locations on the roof. Note that some data during the Post period are missing. Time interval $=$ day. 

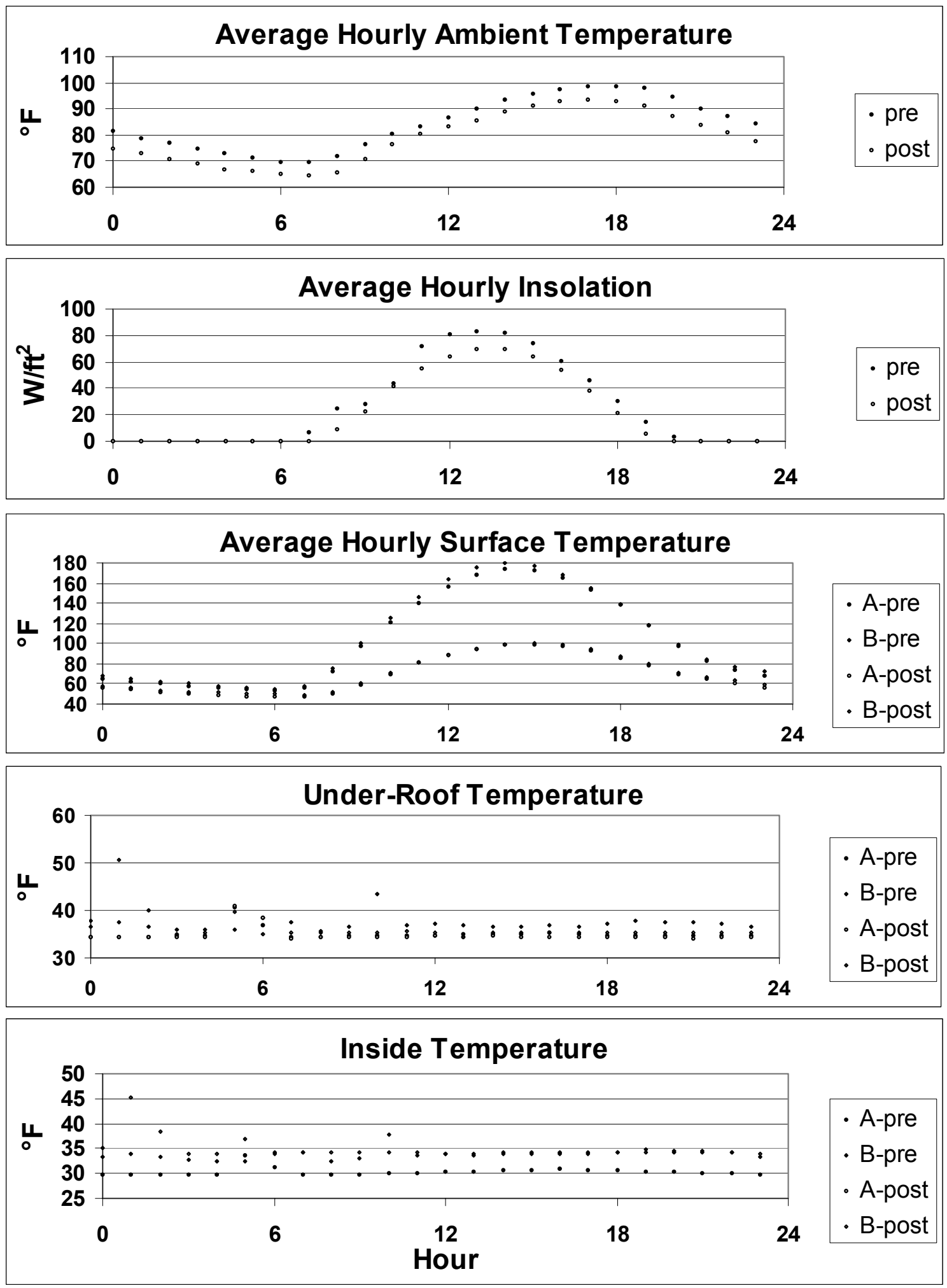

Figure 39. Kaprielian Brothers Packing Company (Cold Storage) Facility in Reedley: Average hourly temperatures and insolation before (Pre) and after (Post) installation of reflective roof coating. ' $\mathrm{A}$ ' and ' $\mathrm{B}$ ' are measurements at two locations on the roof. 


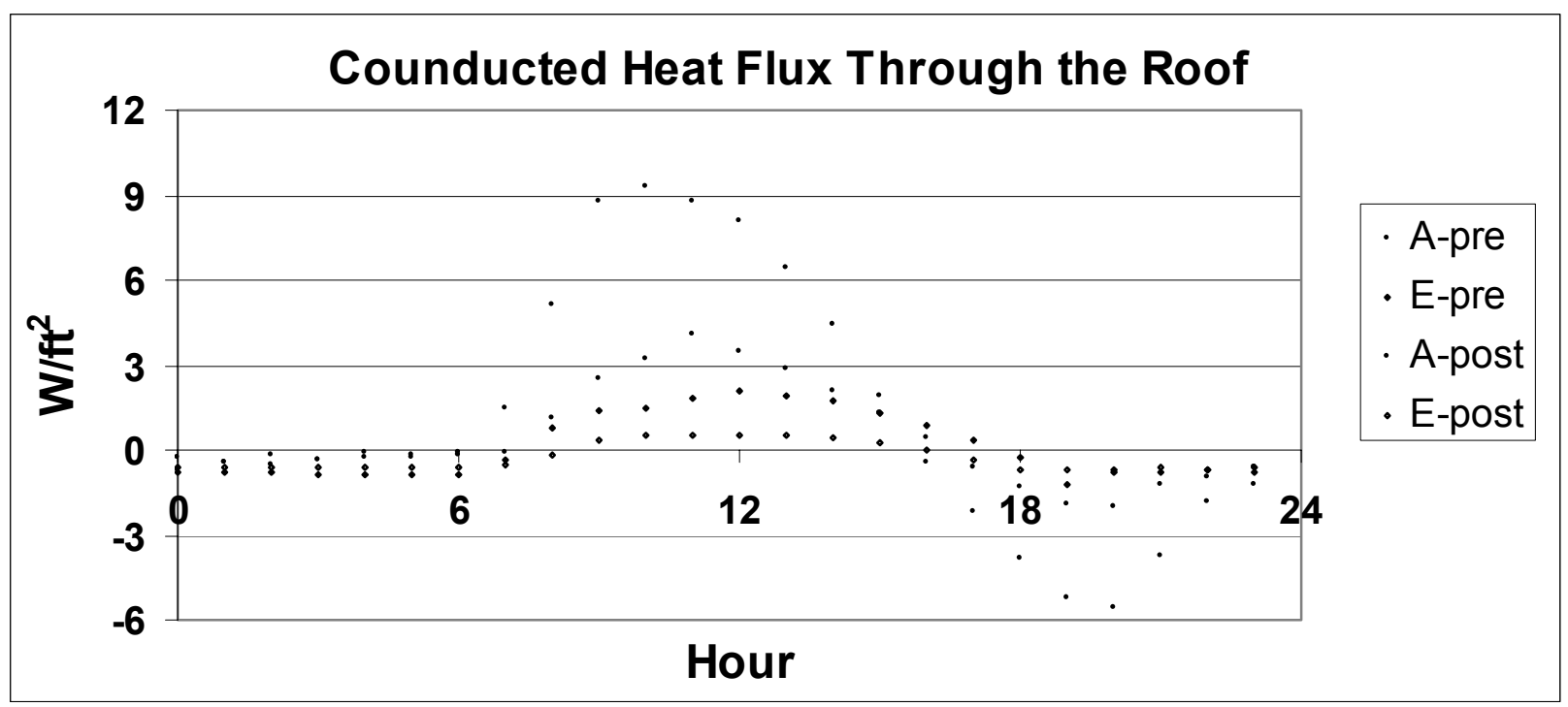

Figure 40. Kaprielian Brothers Packing Company (Cold Storage) facility in Reedley: Average hourly conducted heat flux through the roof before (Pre) and after (Post) installation of reflective roof coating. ' $\mathrm{A}$ ' and ' $\mathrm{E}$ ' are measurements at two locations on the roof.

Conditioning and Palletizing Rooms. Figure 41 shows hourly temperature and conducted heat flux data for a period of two weeks before and three weeks after the roof was coated on August 19, 2002. (Note that the roof at locations ' $C$ ' and ' $D$ ' was not coated until August 23.) In the Pre period, during the hot sunny days, the surface temperature at all monitored locations is about $60-65^{\circ} \mathrm{F}$ warmer than the outdoor temperature. During the nights, the surface temperature cools down to $20^{\circ} \mathrm{F}$ below outdoor temperature. For the Post period, during the days, the maximum surface temperature is only about $10-15^{\circ} \mathrm{F}$ warmer than outdoor temperature. Hence, the reduction in surface temperature after the coating is about $50^{\circ} \mathrm{F}$.

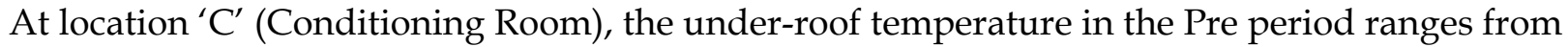
$95-105^{\circ} \mathrm{F}$ and in the Post period to about $80-90^{\circ} \mathrm{F}$, a reduction of about $15^{\circ} \mathrm{F}$. At location ' $\mathrm{D}^{\prime}$

(Palletizing Room), the under-roof temperature in the Pre period ranges from $80-90^{\circ} \mathrm{F}$ and in the Post period to about $70-85^{\circ} \mathrm{F}$, a reduction of about $5-10^{\circ} \mathrm{F}$. The inside temperature in Conditioning Room is about $75-80^{\circ} \mathrm{F}$ for both pre- and post-periods. In the Palletizing Room, the insider temperature is controlled in the range of $66^{\circ} \mathrm{F}$ to $68^{\circ} \mathrm{F}$.

Figure 42 shows the corresponding hourly temperatures averaged over the Pre and Post periods. The average maximum surface temperatures at locations ' $\mathrm{C}$ ' and ' $\mathrm{D}$ ' drop from $140^{\circ} \mathrm{F}$ to about $100^{\circ} \mathrm{F}$. The average maximum under-roof temperatures at location ' $\mathrm{C}$ ' drops from $99^{\circ} \mathrm{F}$ to $89^{\circ} \mathrm{F}$, and at location ' $\mathrm{D}$ ' from $87^{\circ} \mathrm{F}$ to $82^{\circ} \mathrm{F}$. The average maximum inside temperature at both locations ' $\mathrm{C}^{\prime}$ and ' $\mathrm{D}$ ' are about $2^{\circ} \mathrm{F}$ to $3^{\circ} \mathrm{F}$ warmer in the Post period than those of the Pre period.

Packing Areas 1-3. Figure 43 shows hourly temperature and conducted heat flux data for a period of two weeks before and three weeks after the roof was coated on August 19, 2002. (Note that the roof at locations ' $E$ ' and ' $F$ ' was not coated until August 28.) In the Pre period, during the hot sunny days, the surface temperature is about $60-70^{\circ} \mathrm{F}$ warmer than the outdoor temperature. During the nights, the surface temperatures cool down to $10-15^{\circ} \mathrm{F}$ below outdoor temperature. For the Post period, during the days, the maximum surface temperature is only 
about $10-15^{\circ} \mathrm{F}$ warmer than outdoor temperature. Hence, the reduction in surface temperature after the coating is about $50-60^{\circ} \mathrm{F}$.

At location ' $E$ ', for the Pre period the heat flux ranges from -1 to $2 \mathrm{~W} / \mathrm{ft}^{2}\left(-10\right.$ to $\left.22 \mathrm{~W} / \mathrm{m}^{2}\right)$ and for the Post period ranges from -0.8 to $0.6 \mathrm{~W} / \mathrm{ft}^{2}\left(-8\right.$ to $\left.6 \mathrm{~W} / \mathrm{m}^{2}\right)$, a drop of about $1.4 \mathrm{~W} / \mathrm{ft}^{2}$ during peak daytime. Since the flux meter is attached to under-side of the metal roof, the effect of the large diurnal variation in outside surface temperature is significantly dampened. (Assuming an overall COP of 2 for the AC, the reduction in AC energy use is about $0.7 \mathrm{~W} / \mathrm{ft}^{2}$, and for the entire packing area of $36,100 \mathrm{ft}^{2}$ the savings are about $23 \mathrm{~kW}$.)

The under-roof temperature at location ' $\mathrm{F}$ ' during the post-period is about $10^{\circ} \mathrm{F}$ lower than the pre-period. The maximum inside temperature at location $\mathrm{E}$ ranges from $85^{\circ} \mathrm{F}$ to $92^{\circ} \mathrm{F}$ and at location ' $\mathrm{F}$ ' from $78^{\circ} \mathrm{F}$ to $85^{\circ} \mathrm{F}$.

Figure 44 shows the corresponding hourly temperatures averaged over the Pre and Post periods. The maximum surface temperatures at locations ' $\mathrm{E}^{\prime}$ and ' $\mathrm{F}$ ' dropped from about $160^{\circ} \mathrm{F}$ to about $100^{\circ} \mathrm{F}$ after installation of reflective roof coating. The average conducted heat flux through the roof at location ' $F$ ' (see Figure 40) is similar to those discussed above.

The under-roof temperature at location ' $\mathrm{F}$ ' dropped from $100^{\circ} \mathrm{F}$ to about $87^{\circ} \mathrm{F}$. At both locations ' $\mathrm{E}$ ' and ' $\mathrm{F}$ ' in the Packing Rooms, the inside temperature is about $6^{\circ} \mathrm{F}$ lower in the Post period than in Pre period. 

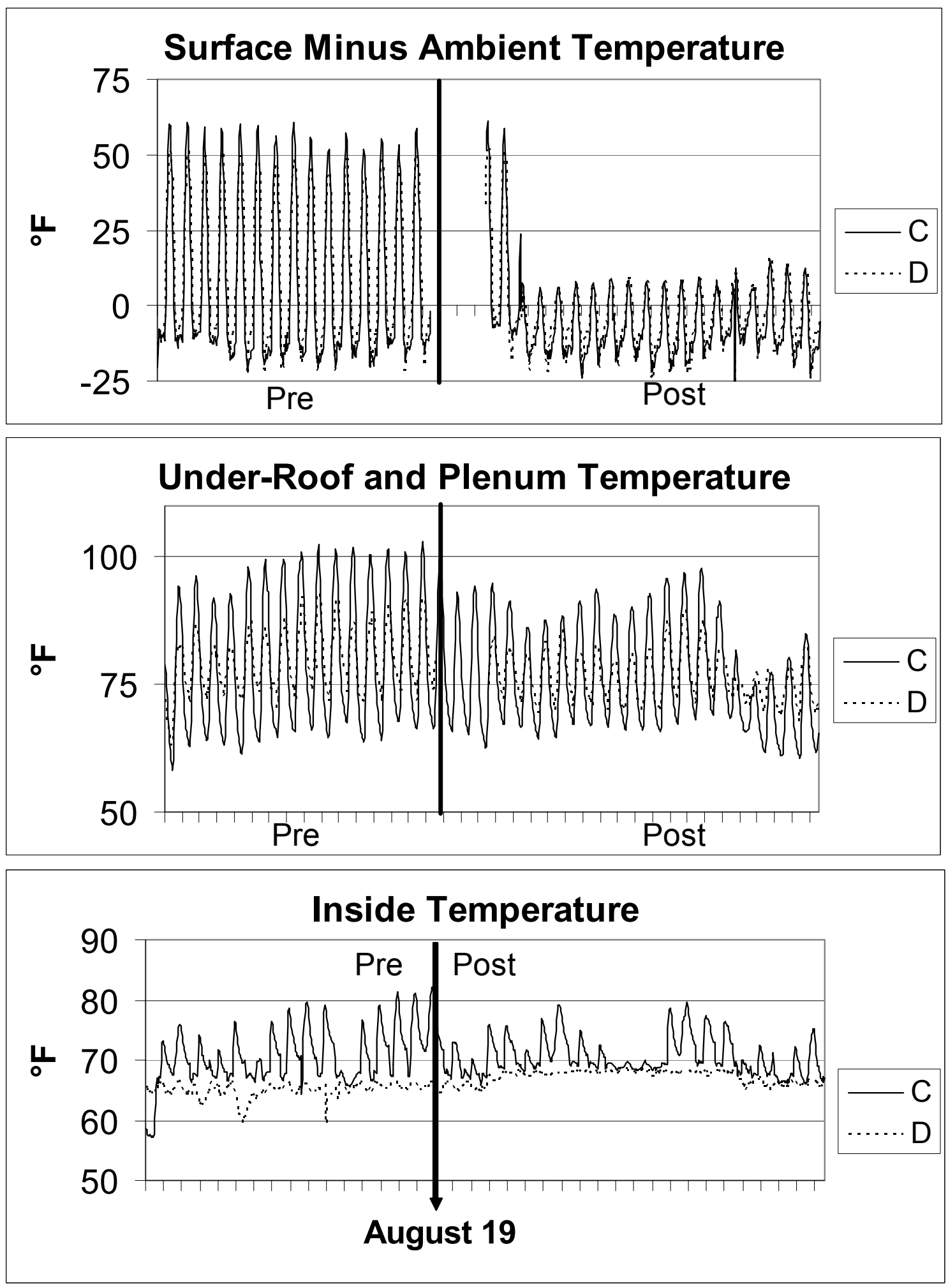

Figure 41. Kaprielian Brothers Packing Company (Cold Storage) Facility in Reedley: Hourly temperatures for two weeks before and three weeks after installation of reflective roof coating on August 19, 2002. ' $\mathrm{C}$ ' and 'D' are measurements at two locations on the roof. Note that some data during the Post period are missing. Time interval = day. 

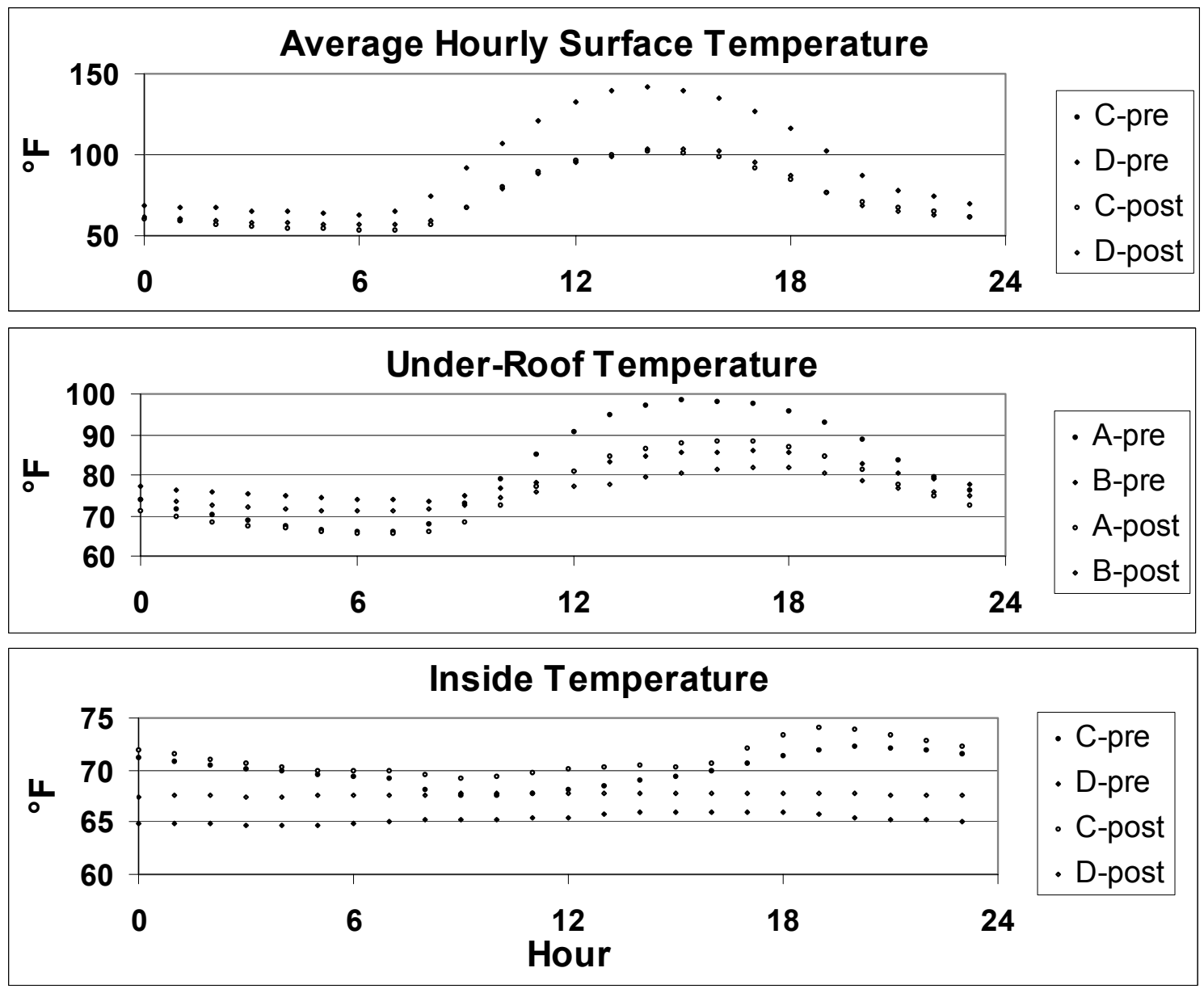

Figure 42. Kaprielian Brothers Packing Company (Cold Storage) Facility in Reedley: Average hourly temperatures before (Pre) and after (Post) installation of reflective roof coating. ' $\mathrm{C}^{\prime}$ and ' $\mathrm{D}$ ' are measurements at two locations on the roof. 

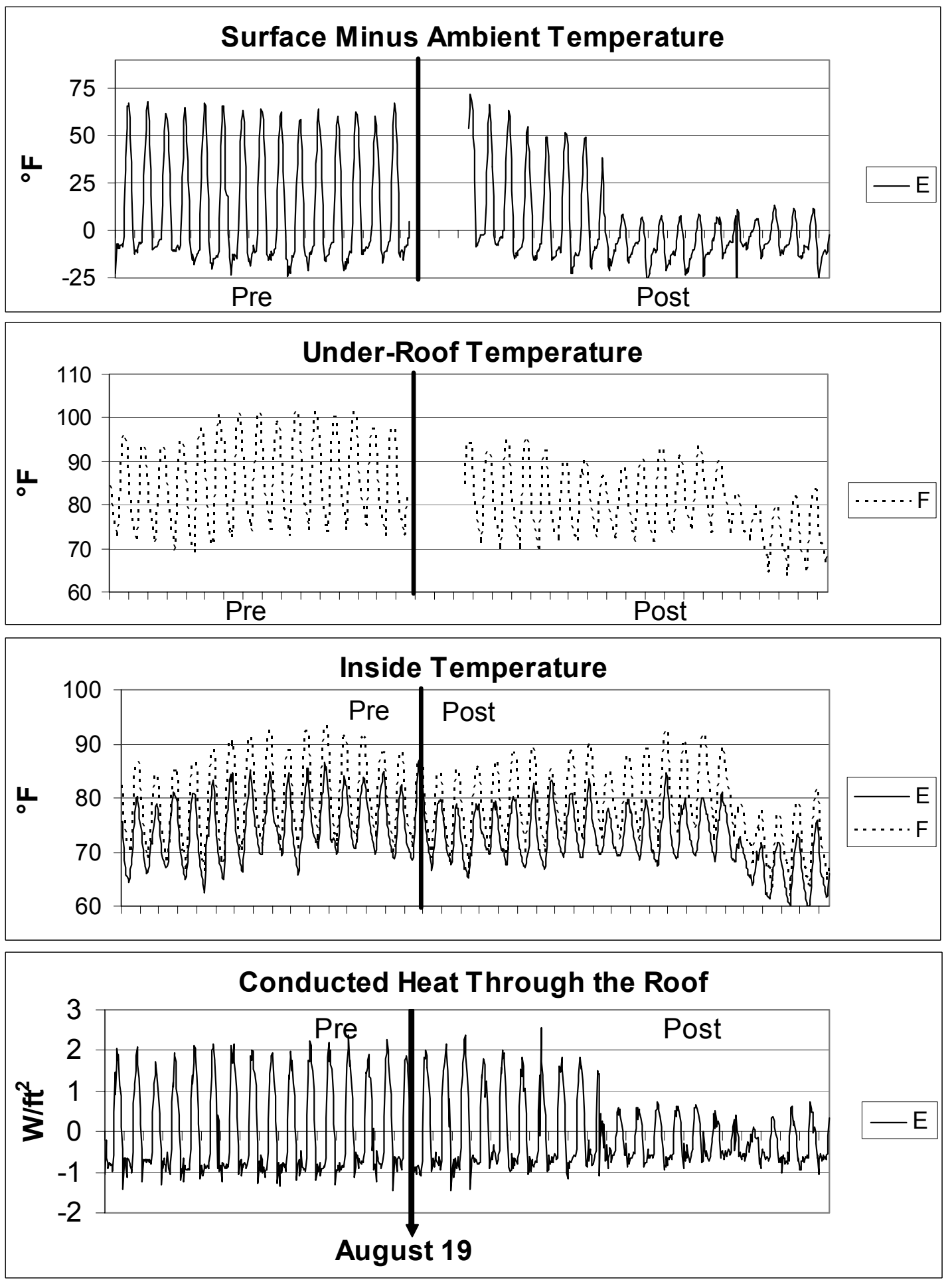

Figure 43. Kaprielian Brothers Packing Company (Cold Storage) Facility in Reedley: Hourly temperatures and conducted heat flux through the roof for two weeks before and three weeks after installation of reflective roof coating on August 19, 2002. ' $E$ ' and ' $F$ ' are measurements at two locations on the roof. Note that some data during the Post period are missing. Time interval = day. 

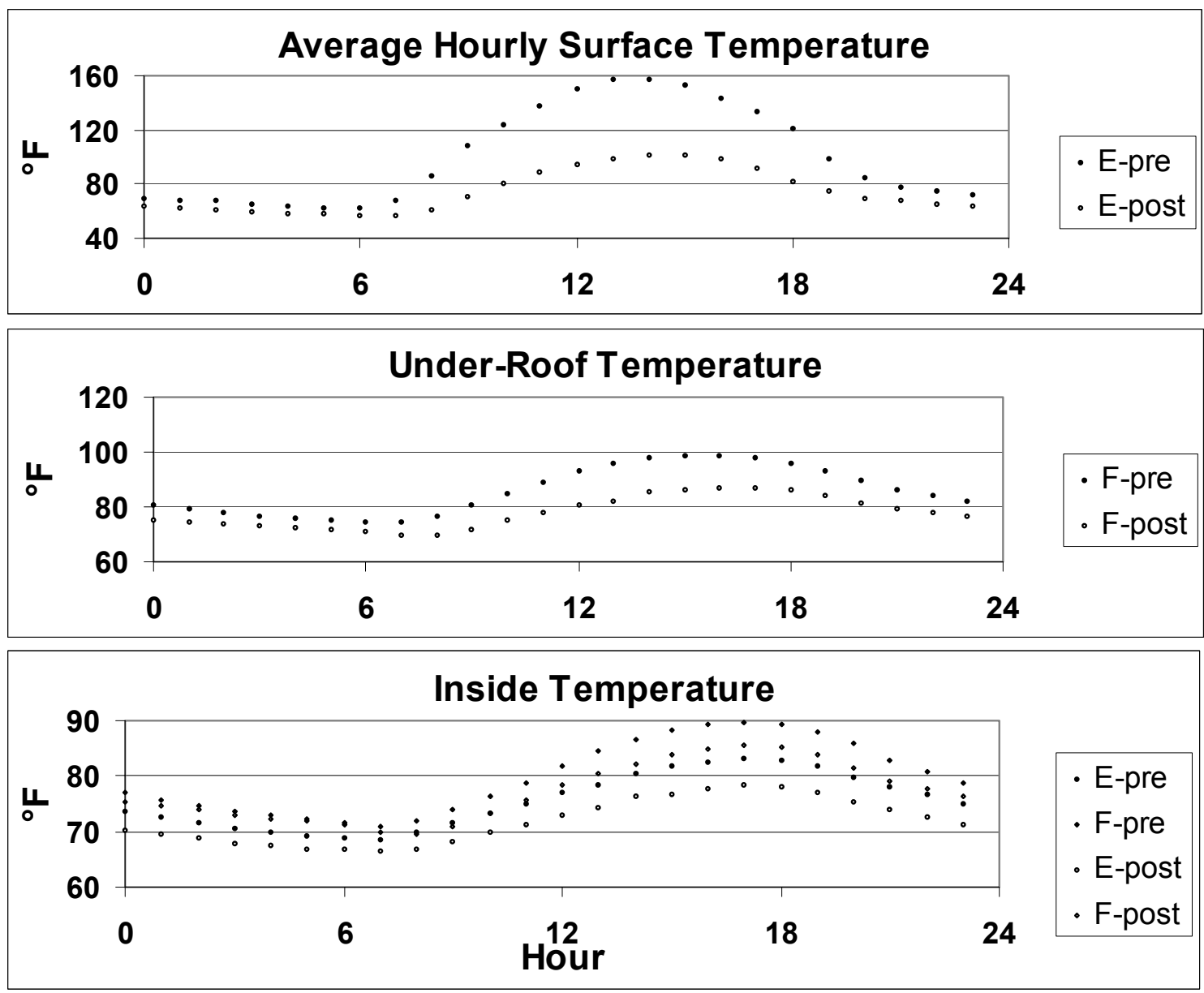

Figure 44. Kaprielian Brothers Packing Company (Cold Storage) Facility in Reedley: Average hourly temperatures before (Pre) and after (Post) installation of reflective roof coating. ' $E$ ' and ' $F$ ' are measurements at two locations on the roof. 
Cold Storage Rooms 11-12. Figure 45 shows hourly temperature data for a period of two weeks before and three weeks after the roof was coated on August 19, 2002. (Note that the roof at locations ' $\mathrm{G}$ ' and ' $\mathrm{H}$ ' was not coated until August 28.) In the Pre period, during the hot sunny days, the surface temperature is about $60-65^{\circ} \mathrm{F}$ warmer than the outdoor temperature. During the nights, the surface temperature cools down to $20-25^{\circ} \mathrm{F}$ below outdoor temperature. This is primarily because of radiation exchange to nighttime clear sky. For the Post period, during the days, the maximum surface temperature is only about $5-15^{\circ} \mathrm{F}$ warmer than outdoor temperature. Hence, the reduction in surface temperature after the coating is about $55-60^{\circ} \mathrm{F}$.

Like locations ' $\mathrm{A}$ ' and ' $\mathrm{B}$ ', at both locations ' $\mathrm{G}$ ' and ' $\mathrm{H}$ ', the inside temperature and the underroof temperature closely follow each other. At location ' $G$ ', the under-roof temperature is about $54-58^{\circ} \mathrm{F}$ and the inside temperature $46-48^{\circ} \mathrm{F}$ (the under-roof is about $8-10^{\circ} \mathrm{F}$ warmer than inside temperature). At location ' $\mathrm{H}^{\prime}$, the under-roof temperature is about $36-40^{\circ} \mathrm{F}$ and the inside temperature is about $32-35^{\circ} \mathrm{F}$. Also at location ' $\mathrm{G}^{\prime}$, note the distinct daily sharp peak in the cold storage temperature that results from defrosting the evaporators.

Figure 46 shows the corresponding hourly temperatures averaged over the Pre and Post periods. The average maximum surface temperature drops from $155^{\circ} \mathrm{F}$ to about $100^{\circ} \mathrm{F}$. At location ' $\mathrm{H}$ ', average maximum temperature in the Pre period is about $65^{\circ} \mathrm{F}$ higher than the ambient air temperature. On the average, the maximum surface temperature was reduced by about $55^{\circ} \mathrm{F}$ after coating the roof.

At locations ' $\mathrm{G}$ ' and ' $\mathrm{H}$ ', the inside temperature is as much as $12^{\circ} \mathrm{F}$ higher in the Post period that Pre period. This signals a major variation in the operation of the facilities. These significant variations between the interior temperature settings, in addition to normal variations in the outdoor temperature and insolation, make the direct comparison of the electricity usages for the entire Pre and Post periods difficult.

Comparing Periods of Pre and Post Retrofit. The period after installing the cool roof coincides with the rapid slowdown in the activities towards the end of summer. Also, during this period, typically the ambient outdoor temperature cools down rapidly. For these reason, a direct comparison of Pre- and Post-retrofit air-conditioning energy use data may lead to erroneous conclusions. In order to minimize these effects (as we will discuss in analysis of air-conditioning electricity use), we compare data for periods of one, two, and three weeks before and after installing cool roofs. These comparisons will provide us with more insight in understanding the savings achieved by installing cool roofs. 

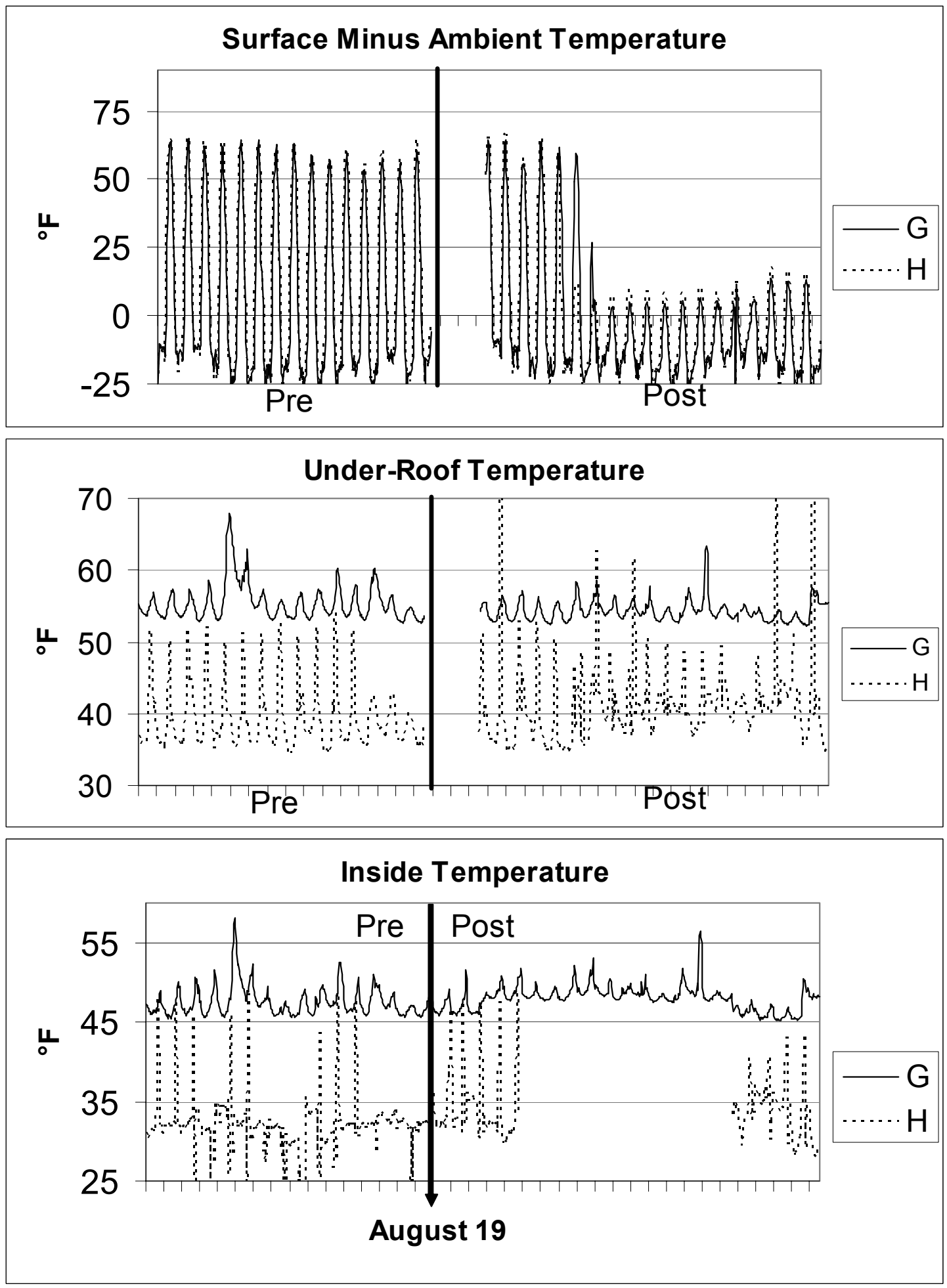

Figure 45. Kaprielian Brothers Packing Company (Cold Storage) Facility in Reedley: Hourly temperatures for two weeks before and three weeks after installation of reflective roof coating on August 19, 2002. 'G' and ' $\mathrm{H}$ ' are measurements at two locations on the roof. Note that some data during the Post period are missing. Time interval = day. 

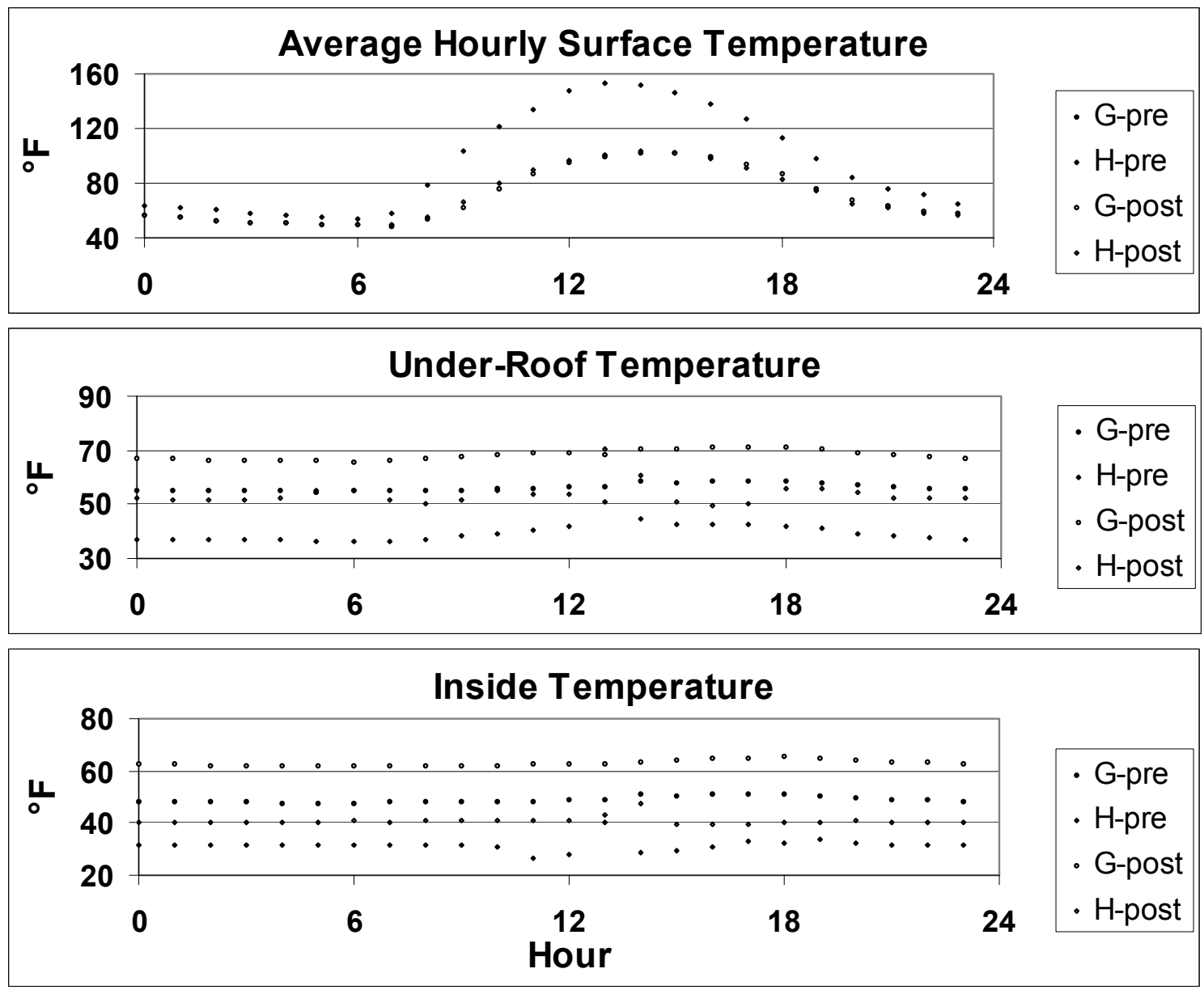

Figure 46. Kaprielian Brothers Packing Company (Cold Storage) Facility in Reedley: Average hourly temperatures before (Pre) and after (Post) installation of reflective roof coating. ' $G$ ' and ' $\mathrm{H}$ ' are measurements at two locations on the roof. Note that some data during the Post period are missing. 
Figure 47 compares the average hour outdoor ambient temperature and average hourly insolation for a one-, two-, and three-week period before and after installing the cool roof. Outdoor temperature is $4^{\circ} \mathrm{F}$ to $8^{\circ} \mathrm{F}$ lower in the Post period in comparison with the Pre period. The insolation data show a higher difference between the Pre and Post periods for the 3-week period, vs. 2-week and one-week periods. In Figure 48, we compare the inside temperature for various regions of the cold-storage facilities. For all inside locations but location ' $\mathrm{H}^{\prime}$, the Preand Post-period temperatures are typically within a few degrees of each other. At location ' $\mathrm{H}^{\prime}$, for some hours during the midday operation, the inside temperatures during the Post period appears to be as much as $8^{\circ} \mathrm{F}$ higher in the Post-period than Pre-period.

\subsubsection{Air Conditioning Energy Use and Savings}

Figure 49 shows the hourly and daily electricity use for the Transformer 2 (T2), chillers (T1), air conditioning system for the packing area (AC), and the other [OTH (=T2-AC): process load, lighting, etc.] usages. The hourly data are shown for a period of two weeks before and three weeks after the beginning of the installation of roof coating (August 19); the daily data are for the entire monitoring period through September 30. The AC (air-conditioning for packing area) is a small component of the total electricity use in the facilities with a typical daily usage 8001,200kWh per day. The T1 (chiller) is the main cooling component for the facilities with daily electricity use in the range of about 10MWh to 13.5MWh per day. The other electricity use (OTH) is approximately about $80 \%$ of the T2 load, with typical daily range of 4.5-6.5MWh. In the Pre period, the T1 has a peak usage of about 700 average $\mathrm{kW}$. During the Post period, for a similar outdoor temperature, the peak T1 usage is about 580 average $\mathrm{kW}$. This suggests a peak demand reductions of about 120 average $\mathrm{kW}$ (about 18\%). We will statistically quantify peak demand savings later on.

For days with similar average temperatures, the Pre AC usage is about $1000 \mathrm{kWh} /$ day and Post usage is about $800 \mathrm{kWh} /$ day. This also suggests savings of about $200 \mathrm{kWh} /$ day (about 20\%) on hot summer days.

It is also noted that the both hourly and daily electricity use for OTH during Pre and about three weeks (after August 19) of the Post period are similar; typically around $6 \mathrm{MWh} /$ day during the week days. During the peak daytime hours, the OTH electricity use ranges from 300$350 \mathrm{kWh}$ per hour. 

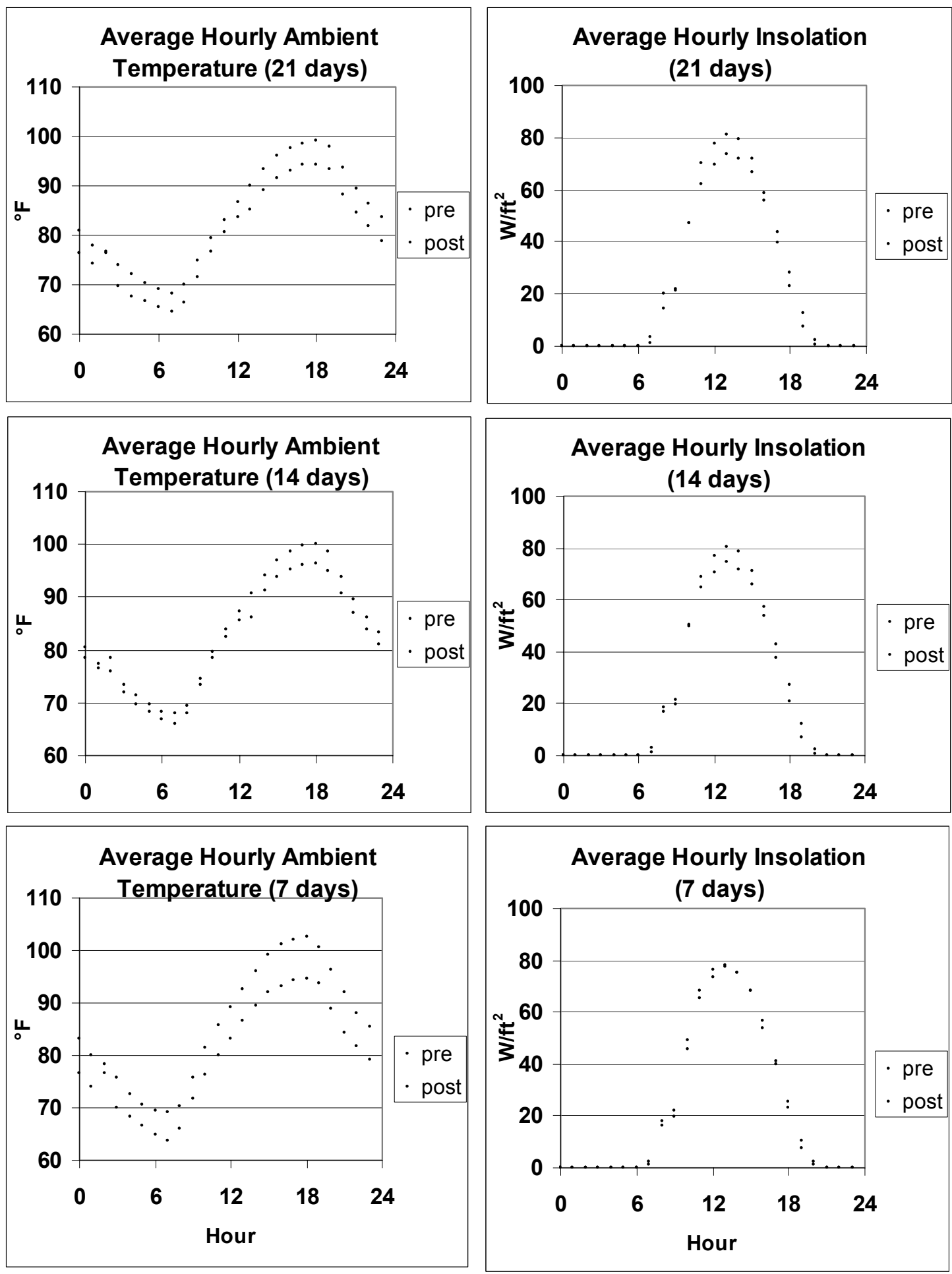

Figure 47. Kaprielian Brothers Packing Company (Cold Storage) Facility in Reedley: Average hourly outdoor temperatures and insolation for periods of 1-, 2-, and 3-weeks before (Pre) and after (Post) installation of reflective roof coating. The "Pre" period is for one, two, or three weeks ending at August 18, 2002. The "Post" period is for one, two or three weeks beginning August 23, 2002. 


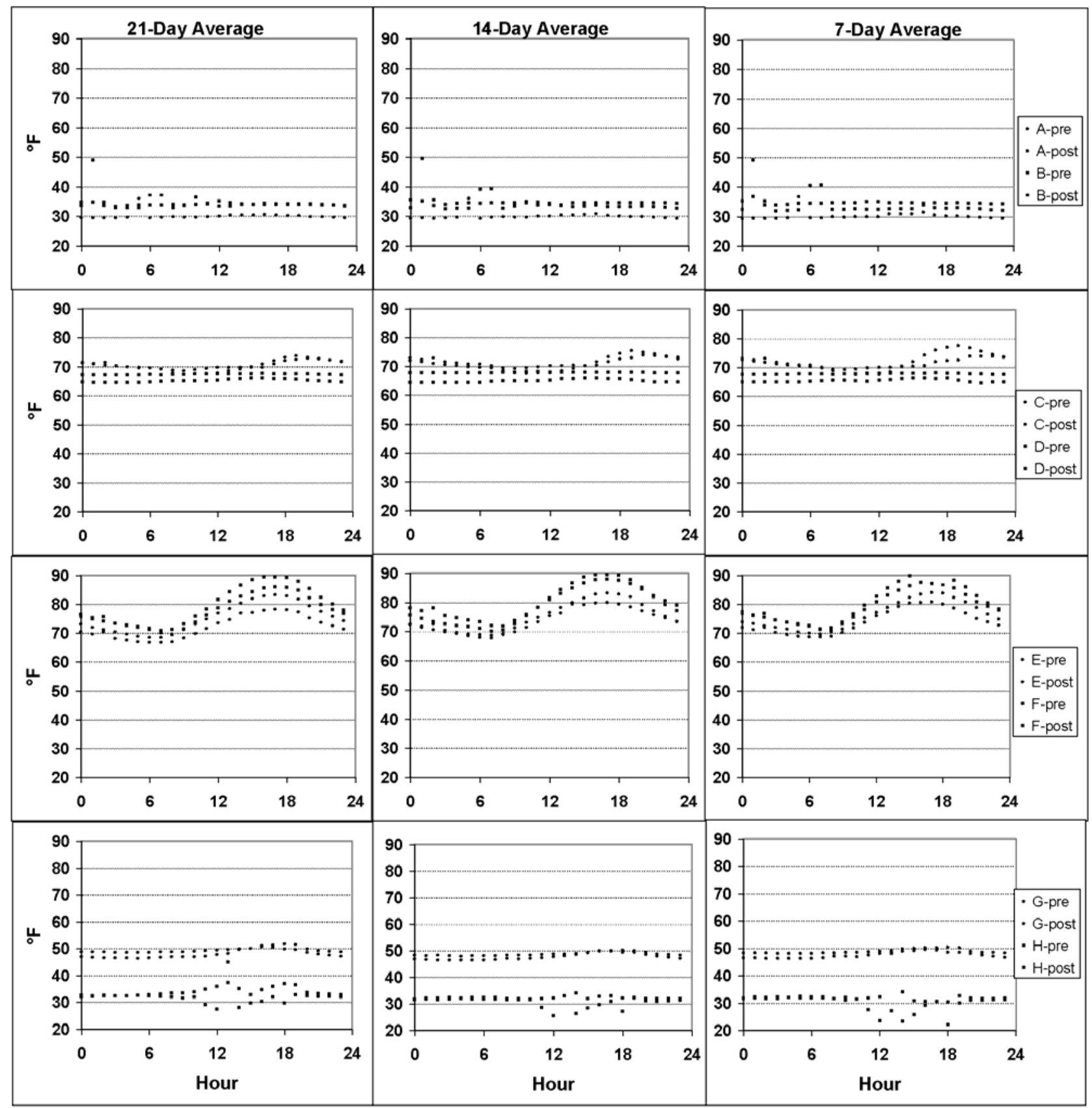

Figure 48. Kaprielian Brothers Packing Company (Cold Storage) Facility in Reedley: Average hourly inside temperatures for periods of 1-, 2-, and 3-weeks before (Pre) and after (Post) installation of reflective roof coating. The "Pre" period is for one, two, or three weeks ending at August 18, 2002. The "Post" period is for one, two or three weeks beginning August 23, 2002. 

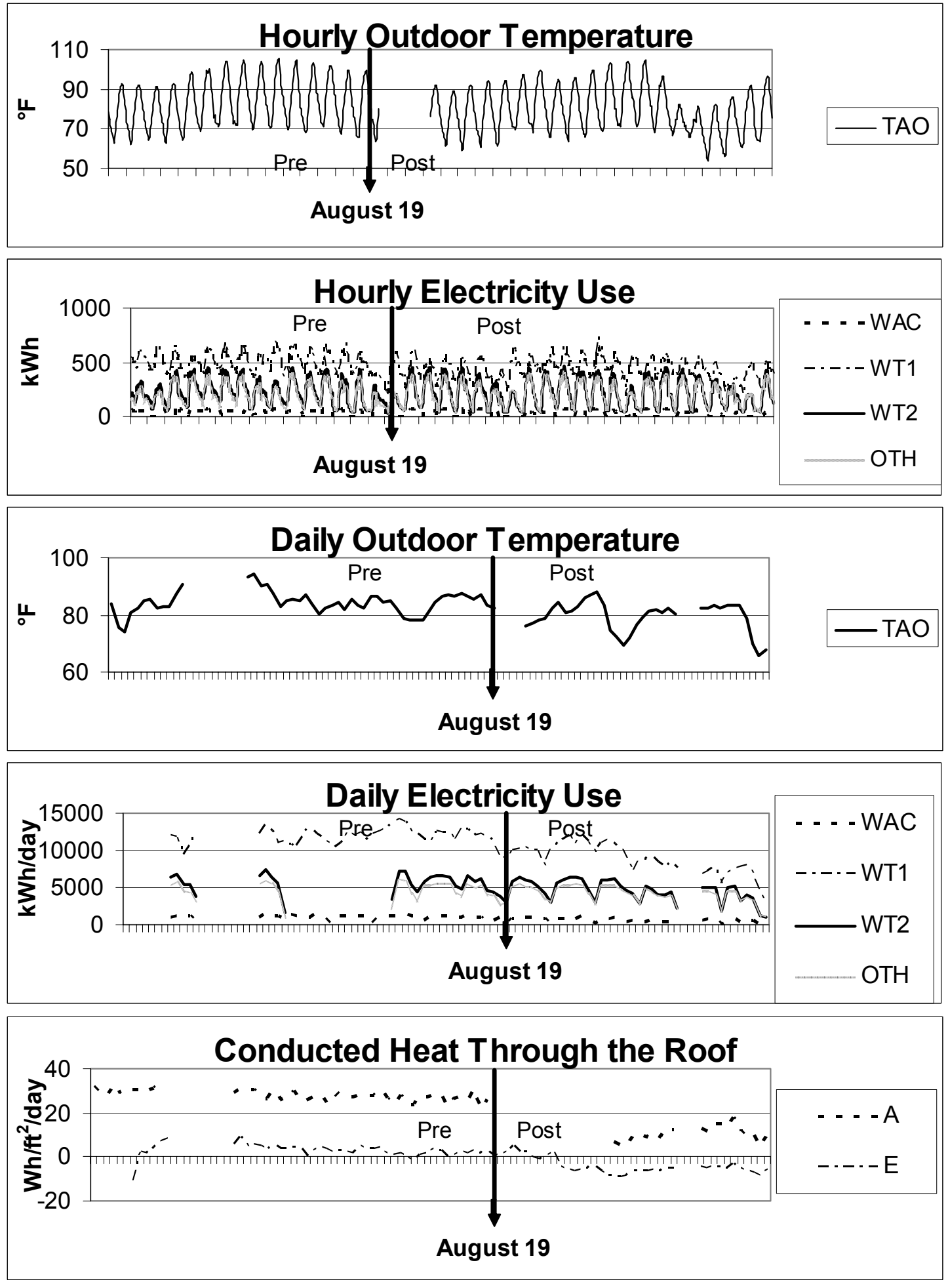

Figure 49. Kaprielian Brothers Packing Company (Cold Storage) Facility in Reedley: Hourly and daily air conditioning energy uses, and roof heat flux. ' $A$ ' and ' $E$ ' are measurements at two locations on the roof; TAO is outdoor temperature, WAC (packing are air conditioners), WT1 (transformer 1: primarily chillers), WT2 (transformer 2), and OTH (other end uses). Time interval $=$ day. 
Kaprielian Brothers Packing Company's operation is highly seasonal; its activities start picking up in June, rapidly approaching a peak in July and August. The daily production of packed fruits from June 19 to September 7, 2002 is shown in Figure 50. Clearly, the daily production has decreased after mid August. So the second half of August and beginning of September is a transitional month and the data obtained for this period should be analyzed carefully to account for the change in the operation. Taking the other load (OTH) as an indication of the activities and cooling operations at the facilities, we observe that the first three weeks of the post period appear to be comparable to the "pre" period. To perform a statistical analysis on the limited data, we defined a new comparable periods of "pre1" (July 23 to August 18) and "post1" (August 24 to September 14). Also note that the roof on the packing area was not coated until August 27-28. We did not eliminate the period of August 24 to August 28 from the "post1" data; the elimination of that period would significantly reduce the number of "post1" data points.

Figure 51 shows the daily electricity use for the chiller (T1) and the packing area AC (AC) as a function the difference between outside and inside temperatures $\left(\Delta T=T_{\text {out }}-T_{\text {in }}\right)$. We performed statistical analyses of electricity use versus (a) difference between outside and inside temperatures $(\Delta T)$, and (b) daily total insolation. The results showed very weak and statistically insignificant correlation of electricity use with temperature difference. The regressions against insolation were even weaker and were not statistically significant. Table 27 summarizes the results of the regression for $\Delta \mathrm{T}$ as independent parameter. Generally, the electricity usage for both $\mathrm{T} 1$ and AC systems were lower during the "post" period.

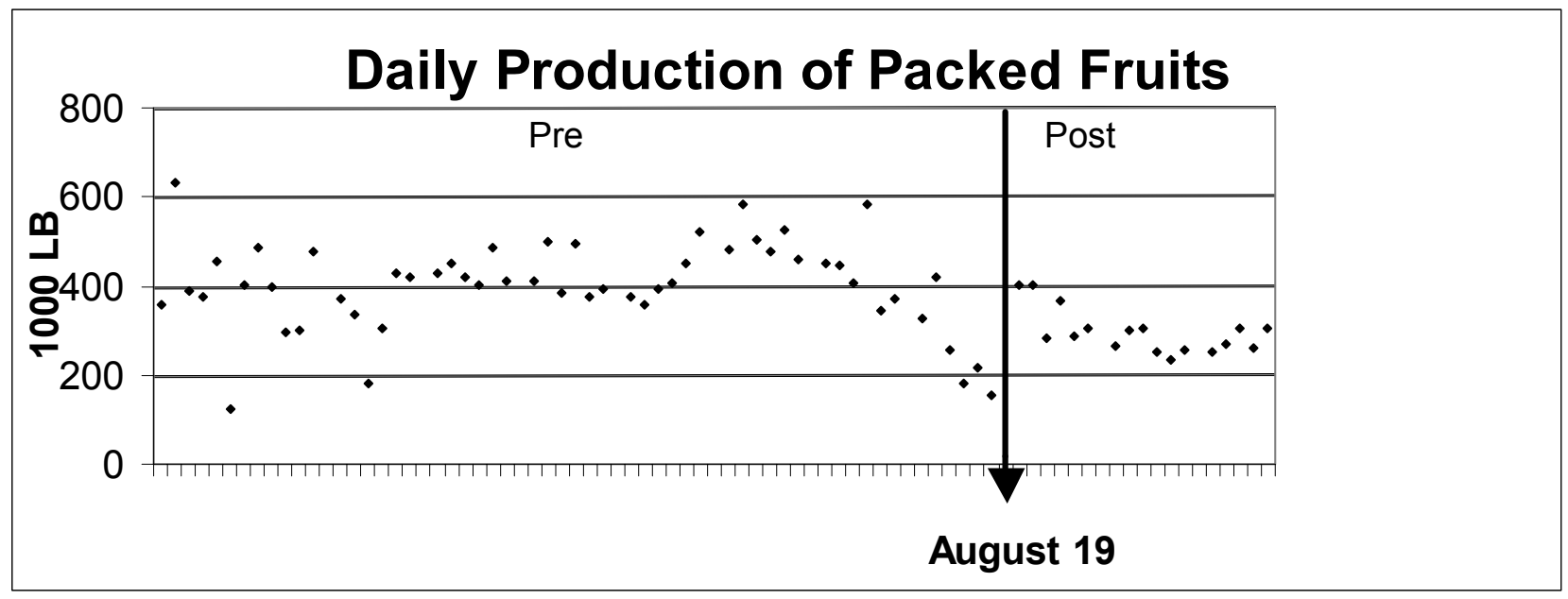

Figure 50. Kaprielian Brothers Packing Company (Cold Storage) Facility in Reedley: Daily production of packed fruits from June 19 to September 7, 2002. Time interval = day. 

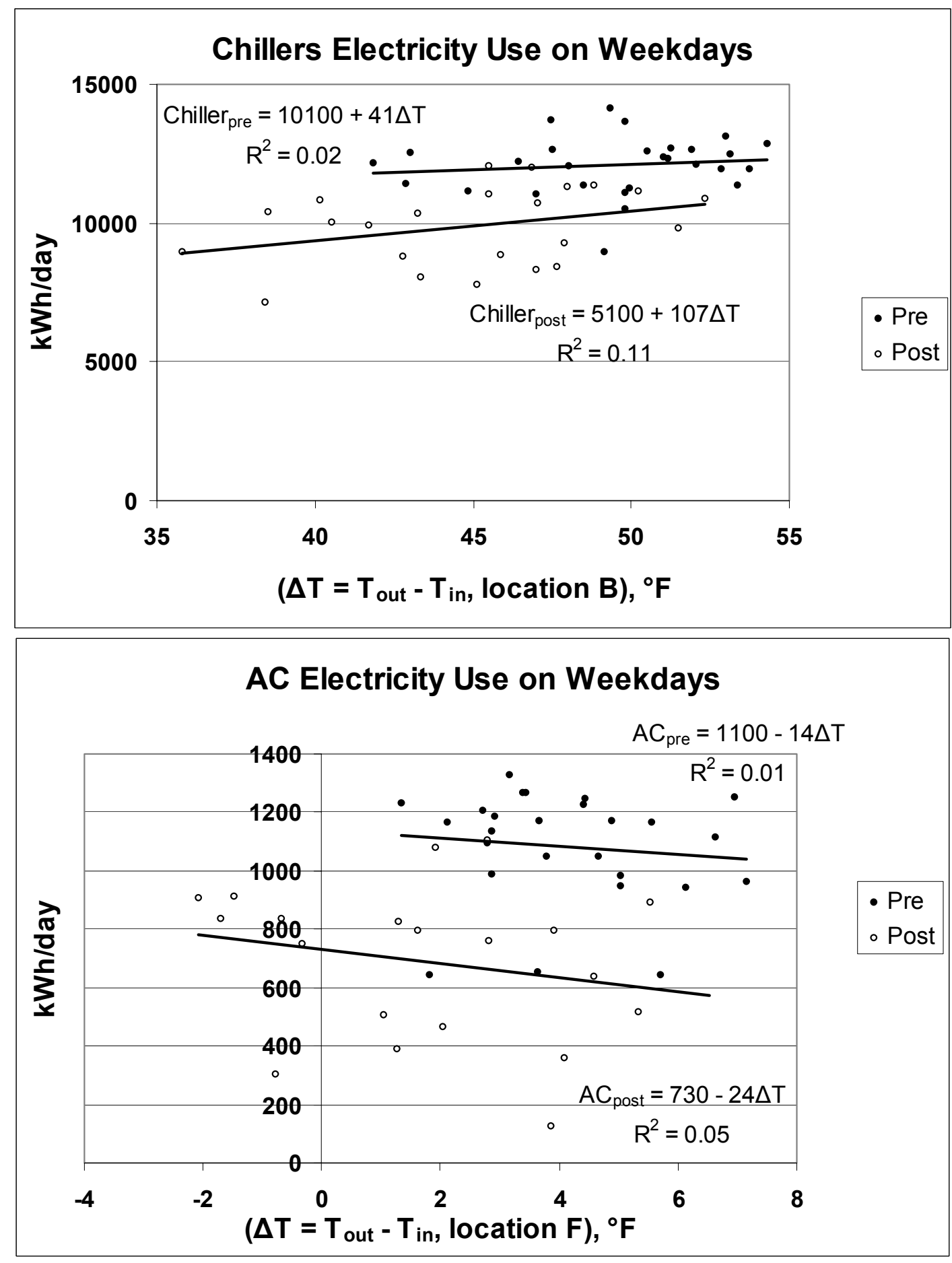

Figure 51. Kaprielian Brothers Packing Company (Cold Storage) Facility in Reedley: Daily electricity use for weekdays for chiller (T1) and air conditioning (AC) for packing area during Pre and Post periods as a function of daily outdoor and indoor temperature difference $(\Delta \mathrm{T}=$ $\mathrm{T}_{\text {out }}-\mathrm{T}_{\text {in }}$. . Daily electricity use regression statistics for the air conditionings. "Pre" period is from July 23 to August 18, 2002; "Post" period is from August 24 to September 14, 2002. Note that none of the correlations are statistically significant, i.e., the chiller and AC electricity use is independent of daily temperature variation. 


\section{Estimate 1 of Base Cooling Electricity Use and Savings}

Cooling Electricity Use for Cold Storage Areas, Conditioning Room, and Palletizing Room. Using the correlation in Table 27, we estimated the chiller (T1) daily electricity use (see Table 28). During the Pre period (July 23 to August 19, 2002), the daily average chiller (T1) electricity use was 12.1 MWh per day. During the Post period (August 24 to September 14, 2002), the average daily A/C electricity use was $9.9 \mathrm{MWh}$ per day. Without correcting for weather conditions of the Pre and Post period, the savings are estimated at $2.2 \mathrm{MWh} /$ day (18\%). Using the difference of average outdoor and indoor temperatures (statistically insignificant correlation), the savings were estimated at 1.6 MWh/day and $2.3 \mathrm{MWh} /$ day (13\% and 19\%) for Pre and Post periods, respectively. The total area of the cold storage, conditioning, and palletizing room is about $66,600 \mathrm{ft}^{2}$. The area-normalized estimated saving are about $24-35$ $\mathrm{Wh} / \mathrm{ft}^{2}$.

Cooling Electricity Use for Package Area \#1. Using the correlation in Table 27, we estimated the packing area AC (AC) daily electricity use (see Table 28). During the Pre period, the daily average AC electricity use was 1,080 kWh per day. During the Post period, the average daily A/C electricity use was $690 \mathrm{kWh}$ per day. Without correcting for weather conditions of the Pre and Post period, the savings are estimated at $370 \mathrm{kWh} /$ day $(34 \%)$. Using the difference of average outdoor and indoor temperatures (statistically insignificant correlation), the savings were estimated at $510 \mathrm{kWh} /$ day and $450 \mathrm{kWh} /$ day $(47 \%$ and 39\%) for Pre and Post periods, respectively. The total area of the package area $\# 1$ is about $23,700 \mathrm{ft}^{2}$. The area-normalized estimated saving are about $16-22 \mathrm{Wh} / \mathrm{ft}^{2}$.

Total Cooling Energy Use. Using the correlation in Table 27, we estimated the total cooling $(\mathrm{TOT}=\mathrm{T} 1+\mathrm{AC}$ ) daily electricity use for the facilities (see Table 28). The total (TOT) cooling data are dominated by the chiller (T1) electricity use. During the Pre period, the daily average TOT electricity use was 13.2 MWh per day. During the Post period, the average daily A/C electricity use was 10.6 MWh per day. Without correcting for weather conditions of the Pre and Post period, the savings are estimated at 2.6 MWh/day (20\%). Using the difference of average outdoor and indoor temperatures, the savings were estimated at $2.2 \mathrm{MWh} /$ day and 2.8 MWh/day (17\% and 21\%) for Pre and Post periods, respectively.

\section{Estimate 2 of Base Cooling Electricity Use Savings}

Since the operation of the facility slows down in September, we also compared average cooling electricity uses for periods of one week, two weeks, and three weeks before and after installation of cool roofs. The Pre periods were estimated for one, two, or three weeks ending at August 18, 2002. The Post periods were estimated for one, two or three weeks beginning August 23, 2002. The results are summarized in Table 29.

\section{Cooling Electricity Use for Cold Storage Areas, Conditioning Room, and Palletizing Room.} For the chiller (T1), the average base cooling uses for 21-day, 14-day, and 7-day periods before installing cool roof ranged from 11.7 to $12.1 \mathrm{MWh} /$ day (varying less than $2 \%$ from an average of about $11.9 \mathrm{MWh}$ /day). The average base cooling use for 21-day, 14-day, and 7-day periods after installing cool roof ranged from 10.1 to $10.7 \mathrm{MWh}$ / day (a variation of less than $3 \%$ from an average of about 10.4 MWh/day). The 21-day average savings were $2.2 \mathrm{MWh} /$ day (18\%), the 
14-day average savings were 1.2 MWh/day (10\%), and for 7-day average savings were 1.4MWh/day (12\%). The area-normalized estimated saving are about $18-33 \mathrm{Wh} / \mathrm{ft}^{2}$.

Table 27. Kaprielian Brothers Packing Company (Cold Storage) Facility in Reedley: Regression of air conditioner daily electricity use $\mathrm{E}(\mathrm{kWh})$ to temperature difference $\Delta \mathrm{T}=\mathrm{T}_{\text {out }}-\mathrm{T}_{\text {in }}\left({ }^{\circ} \mathrm{F}\right)$

\begin{tabular}{|c|c|c|c|c|c|c|}
\hline \multirow[t]{2}{*}{ A/C System } & \multicolumn{3}{|l|}{ Pre } & \multicolumn{3}{|l|}{ Post } \\
\hline & $\mathrm{C}_{0}$ & $\mathrm{C}_{1}$ & $\mathrm{R}^{2}$ & $\mathrm{C}_{0}$ & $\mathrm{C}_{1}$ & $\mathrm{R}^{2}$ \\
\hline \multicolumn{7}{|l|}{ Chiller (WT1) } \\
\hline $\mathrm{E}=\mathrm{C}_{0}+\mathrm{C}_{1} \Delta \mathrm{T}$ & 10100 & 41 & 0.02 & 5100 & 107 & 0.11 \\
\hline \multicolumn{7}{|l|}{ AC of Package Area (WAC) } \\
\hline $\mathrm{E}=\mathrm{C}_{0}+\mathrm{C}_{1} \Delta \mathrm{T}$ & 1140 & -14.45 & 0.01 & 733 & -24.16 & 0.05 \\
\hline
\end{tabular}

Notes: "pre" period is from July 23 to August 18, 2002; "post" period is from August 24 to September 14, 2002. Note that none of the correlations are statistically significant, i.e., the chiller and processing AC electricity uses are independent of daily temperature variation. 
Table 28. Kaprielian Brothers Packing Company (Cold Storage) Facility in Reedley: Estimates of average daily A/C electricity savings.

\begin{tabular}{|c|c|c|c|c|c|c|}
\hline \multirow{2}{*}{ A/C System } & \multicolumn{3}{|c|}{ Pre: July 23 to August 18, 2002} & \multicolumn{3}{|c|}{$\begin{array}{l}\text { Post: August } 23 \text { to September 14, } \\
2002 \text { (ONE LINE?) }\end{array}$} \\
\hline & $\begin{array}{l}\text { Base use } \\
(\mathrm{kWh} / \mathrm{d})\end{array}$ & $\begin{array}{l}\text { Savingsa,c } \\
(\mathrm{kWh} / \mathrm{d})\end{array}$ & $\begin{array}{l}\text { Savings } \\
(\%)\end{array}$ & $\begin{array}{l}\text { Base use } \\
(\mathrm{kWh} / \mathrm{d})\end{array}$ & $\begin{array}{l}\text { Savingsa,c } \\
(\mathrm{kWh} / \mathrm{d})\end{array}$ & $\begin{array}{l}\text { Savings } \\
(\%)\end{array}$ \\
\hline Chiller & 12,000 & 1,800 & 15 & 10,100 & 1,900 & 15 \\
\hline $\begin{array}{l}\text { AC for packing } \\
\text { area }\end{array}$ & 1,100 & 38 & 3 & 1,100 & 38 & 3 \\
\hline $\begin{array}{l}\text { Chiller + AC for } \\
\text { packaging area }\end{array}$ & 13,100 & 1,800 & 14 & 11,200 & 1,900 & 14 \\
\hline \multirow{2}{*}{ A/C System } & \multicolumn{3}{|c|}{ Pre: July 11 to August 18, 2002} & \multicolumn{3}{|c|}{ Post: July 11 to August 18, 2003} \\
\hline & $\begin{array}{l}\text { Base use } \\
(\mathrm{kWh} / \mathrm{d})\end{array}$ & $\begin{array}{l}\text { Savings b,c } \\
(\mathrm{kWh} / \mathrm{d})\end{array}$ & $\begin{array}{l}\text { Savings } \\
(\%)\end{array}$ & $\begin{array}{l}\text { Base use } \\
(\mathrm{kWh} / \mathrm{d})\end{array}$ & $\begin{array}{l}\text { Savingsb,c } \\
(\mathrm{kWh} / \mathrm{d})\end{array}$ & $\begin{array}{l}\text { Savings } \\
(\%)\end{array}$ \\
\hline Chiller & 11,900 & 2200 & 18 & 9,700 & 2200 & 18 \\
\hline $\begin{array}{l}\text { AC for packing } \\
\text { area }\end{array}$ & 1,100 & 0 & 0 & 1,100 & 0 & 0 \\
\hline $\begin{array}{l}\text { Chiller + AC for } \\
\text { packaging area }\end{array}$ & 13,000 & 2200 & 17 & 10,800 & 2200 & 17 \\
\hline
\end{tabular}

\section{Notes:}

a. Savings are based on $\left(\Delta T=T_{\text {out }}-T_{\text {in }}\right)$.

b. Savings are based on the difference of Pre and Post-retrofit electricity use.

c. Most savings are from increasing the evaporator pressure of chillers. 
Table 29. Kaprielian Brothers Packing Company (Cold Storage) Facility in Reedley: Estimates of average daily A/C electricity savings based on average electricity use for a 21-day, a 14-day, and a 7-day period before and after installing cool roof. The numbers in parentheses are standard errors of estimates.

\begin{tabular}{|c|c|c|c|c|c|c|c|c|}
\hline \multirow[t]{3}{*}{ Period } & \multicolumn{4}{|l|}{ Chiller } & \multicolumn{4}{|c|}{$\mathrm{AC}$ for packaging area } \\
\hline & \multirow{2}{*}{$\begin{array}{l}\text { Pre } \\
(\mathrm{kWh} / \mathrm{d})\end{array}$} & \multirow{2}{*}{\begin{tabular}{|l|} 
Post \\
$(\mathrm{kWh} / \mathrm{d})$
\end{tabular}} & \multicolumn{2}{|l|}{ Savings } & \multirow{2}{*}{$\begin{array}{l}\text { Pre } \\
(\mathrm{kWh} / \mathrm{d})\end{array}$} & \multirow{2}{*}{$\begin{array}{l}\text { Post } \\
(\mathrm{kWh} / \mathrm{d})\end{array}$} & \multicolumn{2}{|l|}{ Savings } \\
\hline & & & $(\mathrm{kWh} / \mathrm{d})$ & $\%$ & & & $(\mathrm{kWh} / \mathrm{d})$ & $\%$ \\
\hline $\begin{array}{l}\text { 21-day } \\
\text { average }\end{array}$ & $\begin{array}{l}\mathbf{1 2 , 1 0 0} \\
(1100)\end{array}$ & $\begin{array}{l}\mathbf{1 0 , 1 0 0} \\
(1300)\end{array}$ & 2,200 & 18 & $\begin{array}{l}\mathbf{1 , 1 0 0} \\
(190)\end{array}$ & $\begin{array}{l}700 \\
(260)\end{array}$ & 343 & 32 \\
\hline $\begin{array}{l}\text { 14-day } \\
\text { average }\end{array}$ & $\begin{array}{l}\mathbf{1 1}, \mathbf{8 0 0} \\
(1000)\end{array}$ & $\begin{array}{l}\mathbf{1 0 , 7 0 0} \\
(1000)\end{array}$ & 1,200 & 10 & $\begin{array}{l}990 \\
(210)\end{array}$ & $\begin{array}{l}870 \\
(130)\end{array}$ & 129 & 13 \\
\hline $\begin{array}{l}\text { 7-day } \\
\text { average }\end{array}$ & $\begin{array}{l}\mathbf{1 1}, \mathbf{7 0 0} \\
(1400)\end{array}$ & $\begin{array}{l}\mathbf{1 0}, 400 \\
(1300)\end{array}$ & 1,400 & 12 & $\begin{array}{l}940 \\
(220)\end{array}$ & $\begin{array}{l}870 \\
(110)\end{array}$ & 68 & 7 \\
\hline
\end{tabular}

Notes: The Pre period is for one, two, or three weeks ending at August 18, 2002. The Post period is for one, two or three weeks beginning August 23, 2002.

Cooling Electricity Use for Packing Area 1. For the packing area AC (AC), the average base cooling uses for 21-day, 14-day, and 7-day periods before installing cool roof ranged from 940 to $1,060 \mathrm{kWh} /$ day (a variation of $6 \%$ from an average of about 1,000 kWh/day). The average base cooling uses for 21-day, 14-day, and 7-day periods after installing cool roof ranged from 720 to $870 \mathrm{kWh} /$ day (varying 10\% from an average of about $795 \mathrm{kWh} /$ day). The 21-day average savings were $340 \mathrm{kWh} /$ day (32\%), the 14-day average savings were $130 \mathrm{kWh} /$ day (13\%), and the 7-day average savings were $70 \mathrm{kWh} /$ day $(7 \%)$. Note that the roof of the packing area was coated on August 27-28, explaining why the savings for the 7-day period is significantly lower. The area-normalized estimated saving are about 3-14 Wh/ $\mathrm{ft}^{2}$.

Total Cooling Energy Use. The average base total cooling use for 21-day, 14-day, and 7-day periods before installing cool roof ranged from 12.7 to $13.2 \mathrm{MWh} /$ day (varying less than $2 \%$ from an average of about 12,950 kWh/day). The average base cooling use for 21-day, 14-day, and 7-day periods after installing cool roof ranged from 10.8 to $11.6 \mathrm{MWh} /$ day (varying less than $4 \%$ from an average of about 11,200 kWh/day). The 21-day average savings were 2.4 MWh/day (18\%), the 14-day average savings were $1.3 \mathrm{MWh} /$ day $(10 \%)$, and the 7 -day average savings were $1.5 \mathrm{MWh} /$ day $(12 \%)$.

In summary, the analysis of the limited 2002 data indicates a reduction of at least $1.3 \mathrm{MWh} /$ day $(10 \%)$ in the cooling load for the entire facility. 

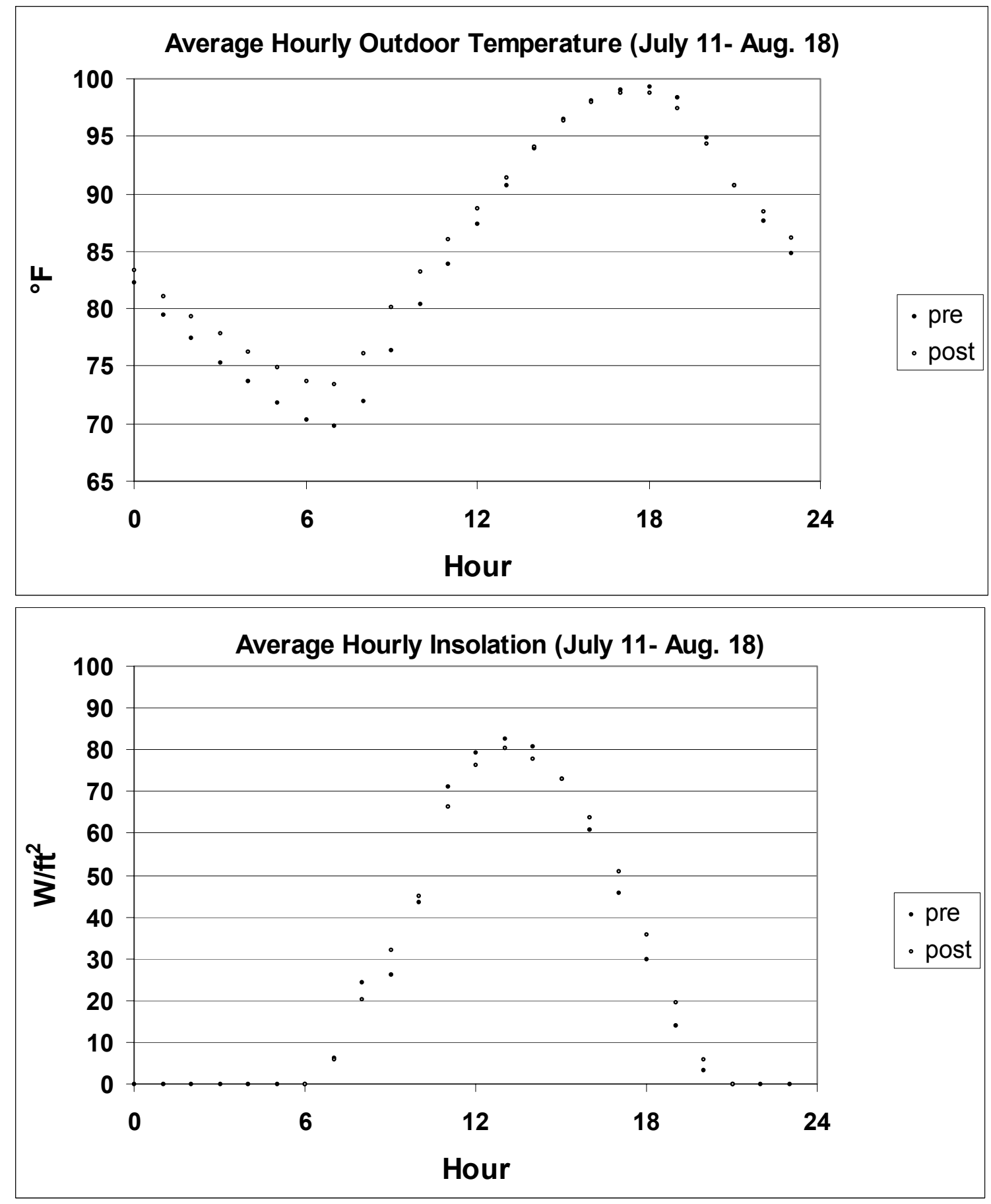

Figure 52. Kaprielian Brothers Packing Company (Cold Storage) Facility in Reedley: Average hourly outdoor temperature and insolation for the period of July 11 through August 18 of 2002 (Pre) and 2003 (Post). 


\section{Estimate of Base Cooling Electricity Use and Savings Using 2002 (Pre) and 2003 (Post) data}

To limit the uncertainty in the estimate of savings, we continued monitoring the facilities through September 2003. For the estimate of base use and savings, we compared two identical period of July 11 through August 18 during 2002 (Pre02) and 2003 (Post03). Figure 52 shows the average hourly outdoor temperature and solar intensity during the pre and post periods. The average temperature during these periods for most of the daytime hours compare within $1^{\circ} \mathrm{F}$ (During the night hours, the average temperature for post period is about $4^{\circ} \mathrm{F}$ warmer than those of the pre period). The hourly solar intensity during these periods is fairly similar; the total daily solar energy during the pre and post periods is about $0.63 \mathrm{kWh} / \mathrm{ft}^{2}$ and $0.61 \mathrm{kWh} / \mathrm{ft}^{2}$ $\left(6.8 \mathrm{kWh} / \mathrm{m}^{2}\right.$ and $\left.6.6 \mathrm{kWh} / \mathrm{m}^{2}\right)$, respectively (a difference of $\left.0.02 \mathrm{kWh} / \mathrm{ft}^{2}[3 \%]\right)$.

\section{Cooling Electricity Use for Cold Storage Areas, Conditioning Room, and Palletizing Room.}

Figure 53 shows the daily electricity use for chiller and AC for packing for 2002 pre-period, 2002 post-period, and 2003 post-period. In this section of the analysis, the "Pre02" period is from July 11 to August 18, 2002; "Post02" period is from August 24 to September 14, 2002, and "Post03" period is from July 11 to August 18, 2003. Note that none of the correlations are statistically significant, i.e., the chiller and AC electricity uses are independent of daily temperature variation. The average chiller energy use during the pre period and Post03 period is 11.9 MWh/day and 9.7 MWh/day, respectively, a difference of $2.3 \mathrm{MWh} /$ day (19\%) (see Table 25. The area-normalized estimated saving are about $34 \mathrm{Wh} / \mathrm{ft}^{2}$. This 'savings' is substantially larger than the estimates from simple heat transfer calculations and suggests other factors as the cause of such large difference. We will discuss this further in the analysis of hourly energy and peakdemand savings.

Cooling Electricity Use for Packing Area 1. As it is depicted in Figure 53, there is no apparent daily AC savings in the Packing Area 1; estimated daily energy savings is about 1\%-3\% (9-33 $\mathrm{kWh}$ / day from an average use of about $1100 \mathrm{kWh} /$ day). This result is significantly different from the previous estimates of savings, using the summer 2002 post-retrofit data. We have noted that the AC systems are frequently 'on' during the night hours of the Post03 period.

Total Cooling Energy Use. The average base total cooling use for the Pre02 period was about 13.1 MWh/day and the average base cooling for the same period in 2003 (Post03) after installing cool roof ranged from 10.8 MWh/day. The estimated 'savings' was about 2.3 MWh/day (18\%-19\%). 


\section{Chillers Electricity Use}

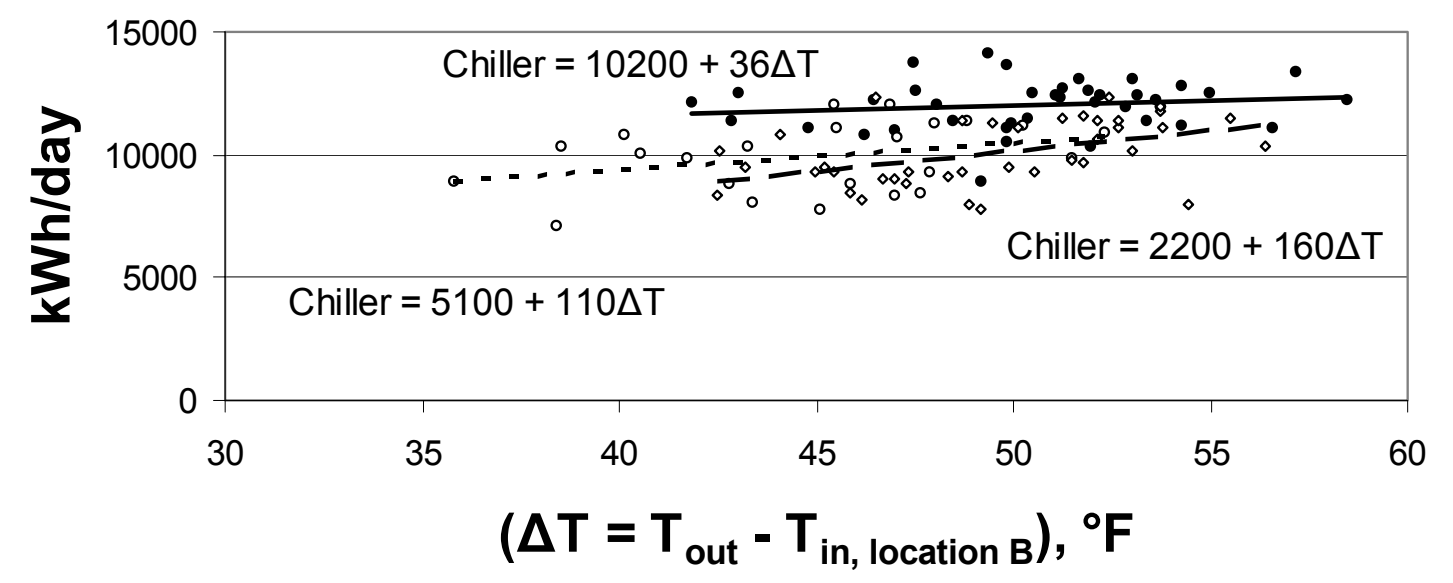

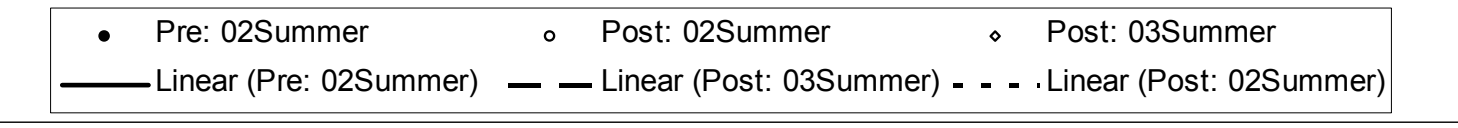

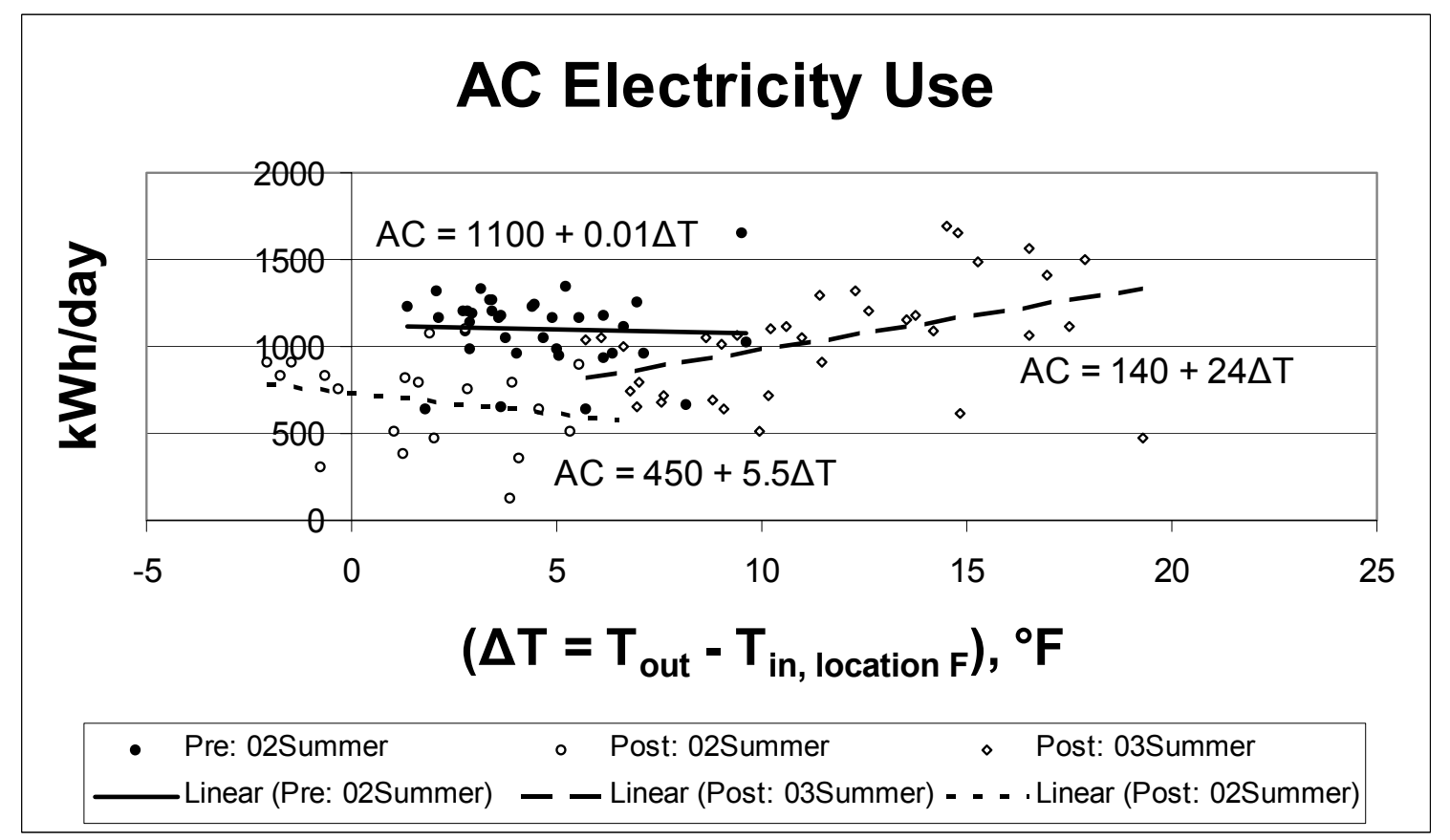

Figure 53. Kaprielian Brothers Packing Company (Cold Storage) Facility in Reedley: Daily electricity use for chiller and AC for packing for 2002 Pre-period, 2002 Post-period, and 2003 Post-period. "Pre" period is from July 11 to August 18, 2002; "Post: 02Summer" period is from August 24 to September 14, 2002, and "Post: 03Summer" period is from July 11 to August 18, 2003. Note that none of the correlations are statistically significant, i.e., the chiller and processing $\mathrm{AC}$ electricity use is independent of daily outdoor and indoor temperature difference $\left(\Delta T=T_{\text {out }}-T_{\text {in }}\right)$ variation. 


\section{Air Conditioning Peak Demand and Savings}

As we discussed before, the daily cooling electricity use data were not significantly correlated to outdoor temperature. The hourly electricity use data (average hourly demand) also did not show significant correlation to outdoor temperature.

\section{Estimate of Peak Electricity Demand Use and Savings Using 2002 pre and post data}

Peak-Demand Cooling Electricity Savings for Cold Storage Areas, Conditioning Room, and

Palletizing Room. Figure $\mathbf{5 4}$ shows the hourly electricity use data for T1. We also calculated the average hourly demands for the hours 12 to 18 (see Table 30). During hours 12 to 18, the average chiller (T1) hourly electricity use was reduced by about $50-120 \mathrm{~kW}$. The hourly electricity demand averaged for hours 12-18 were reduced by $110 \mathrm{~kW}(18 \%), 60 \mathrm{~kW}(10 \%)$, and $70 \mathrm{~kW}(12 \%)$ for 21-, 14-, and 7-days periods, respectively. The area-normalized estimated 'savings' is about $0.8-1.8 \mathrm{~W} / \mathrm{ft}^{2}$.

The hourly data show significant reduction in the chillers' electricity use during the evening and nighttime hours (when there is no sun!). After discussions with the facility engineer, we discovered that two other major changes have occurred that potentially can justify these significant differences between the post and pre periods. First, the electric utility company installed a new transformer and capacitor at the facility during early June 2003 (this would only affect the energy use during summer of 2003). Second, in late summer 2002, the suction pressure of the chiller compressors (and hence, the evaporator temperature) was raised from 32 psia to 35 psia. An increase in the suction pressure (while the discharge pressure is kept constant) can significantly improve the performance of the chiller systems.

To account for the changes in the operation of the chiller systems, we assumed that there should not be any savings during the night hours, if the system were operating under the same conditions during the pre and post period. The average difference between the pre and post period for nighttime hours 9 pm to 3 am was about $74 \mathrm{~kW}, 31 \mathrm{~kW}$, and $44 \mathrm{~kW}$ for 21-, 14-, and 7day periods, respectively. In order to estimate the savings associated with installation of cool roofs, we subtracted these nighttime biases from the difference of the pre- and post-period chiller power demand for all hours. This resulted in average peak demand savings (for hours $12-18)$ of $32-40 \mathrm{~kW}(6-7 \%)$. The estimated normalized peak-demand savings is $0.5-0.6 \mathrm{~W} / \mathrm{ft}^{2}$. This approach also yielded a net daily energy savings of 440-500 kWh (3-4\%); corresponding to a normalized savings of about 6.6-7.5 Wh/ $\mathrm{ft}^{2}$. We believe these results are plausible.

Cooling Electricity Use for Package Area 1. Figure 55 shows the hourly electricity demand data for AC. We also calculated the average hourly demands for the defined periods (see Table 31). During hours 12 to 18, the average peak-demand A/C use for the package area 1 was reduced by about $9-14 \mathrm{~kW}$. The hourly electricity use averaged for hours 12-18 was reduced by $14 \mathrm{~kW}$ $(26 \%), 9 \mathrm{~kW}(16 \%)$, and $13 \mathrm{~kW}(23 \%)$ for the $21-, 14-$, and 7-day periods, respectively. The areanormalized estimated 'savings' is about $0.4-0.6 \mathrm{~W} / \mathrm{ft}^{2}$. 

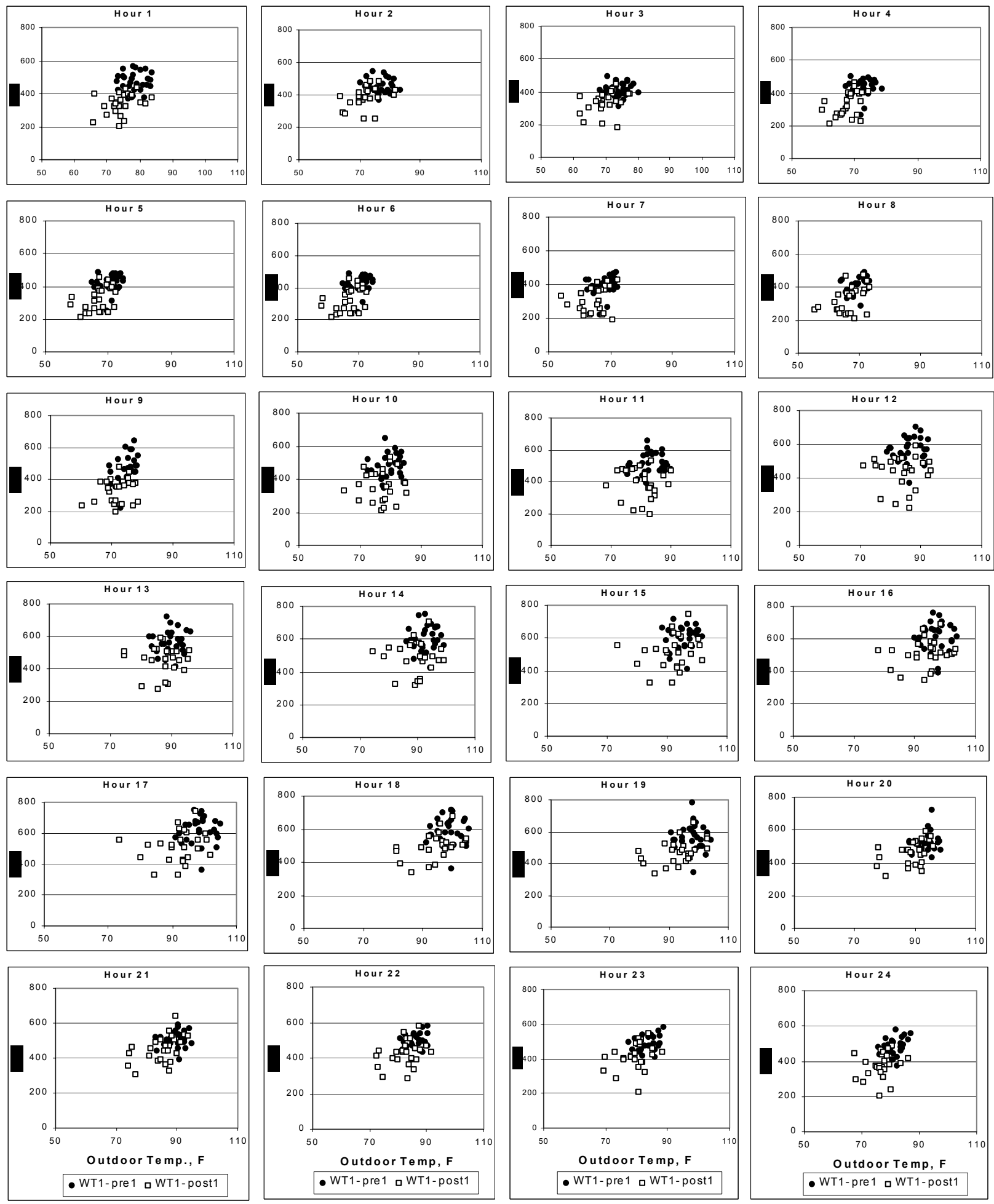

Figure 54. Kaprielian Brothers Packing Company (Cold Storage) Facility in Reedley: Electrical demand as a function of outdoor temperature for the chiller (WT1). 
Table 30. Kaprielian Brothers Packing Company (Cold Storage) Facility in Reedley: Chiller power demand and savings.

\begin{tabular}{|c|c|c|c|c|c|c|c|c|c|c|c|c|c|c|c|c|c|c|}
\hline \multirow{3}{*}{ Hour } & \multicolumn{3}{|c|}{ Power demand: } & \multicolumn{3}{|c|}{ Power demand: } & \multicolumn{6}{|c|}{ Pre - Post } & \multicolumn{6}{|c|}{ (Pre - Post) -(nighttime bias) } \\
\hline & \multirow{2}{*}{$\frac{21-\text { day }}{\mathrm{kW}}$} & \multirow{2}{*}{$\begin{array}{c}\text { 14-day } \\
\mathrm{kW} \\
\end{array}$} & \multirow{2}{*}{$\begin{array}{r}\text { 7-day } \\
\mathrm{kW} \\
\end{array}$} & \multirow{2}{*}{$\frac{21-d a y}{\mathrm{~kW}}$} & \multirow{2}{*}{$\frac{14-d a y}{\mathrm{~kW}}$} & \multirow{2}{*}{$\begin{array}{r}\text { 7-day } \\
\mathrm{kW}\end{array}$} & \multicolumn{2}{|l|}{ 21-day } & \multicolumn{2}{|c|}{ 14-day } & \multicolumn{2}{|l|}{ 7-day } & \multicolumn{2}{|c|}{ 21-day } & \multicolumn{2}{|c|}{ 14-day } & \multicolumn{2}{|c|}{ 7-day } \\
\hline & & & & & & & $\mathrm{kW}$ & $\%$ & $\mathrm{~kW}$ & $\%$ & $\mathrm{~kW}$ & $\%$ & $\mathrm{~kW}$ & $\%$ & $\mathrm{~kW}$ & $\%$ & $\mathrm{~kW}$ & $\%$ \\
\hline 1 & 486 & 467 & 468 & 393 & 416 & 411 & 93 & 19 & 51 & 11 & 57 & 12 & & & & & & \\
\hline 2 & 477 & 451 & 436 & 352 & 375 & 369 & 125 & 26 & 76 & 17 & 67 & 15 & & & & & & \\
\hline 3 & 463 & 443 & 439 & 393 & 416 & 411 & 70 & 15 & 27 & 6 & 28 & 6 & & & & & & \\
\hline 4 & 422 & 406 & 410 & 355 & 375 & 366 & 67 & 16 & 31 & 8 & 44 & 11 & & & & & & \\
\hline 5 & 446 & 432 & 437 & 352 & 376 & 352 & 94 & 21 & 56 & 13 & 85 & 19 & & & & & & \\
\hline 6 & 433 & 420 & 425 & 340 & 364 & 341 & 93 & 21 & 56 & 13 & 84 & 20 & & & & & & \\
\hline 7 & 406 & 390 & 386 & 334 & 356 & 338 & 72 & 18 & 34 & 9 & 48 & 12 & -2 & 0 & 3 & 1 & 4 & 1 \\
\hline 8 & 414 & 411 & 424 & 328 & 349 & 333 & 86 & 21 & 62 & 15 & 91 & 21 & 12 & 3 & 31 & 7 & 47 & 13 \\
\hline 9 & 433 & 423 & 442 & 331 & 348 & 318 & 102 & 24 & 75 & 18 & 124 & 28 & 28 & 7 & 44 & 10 & 80 & 23 \\
\hline 10 & 478 & 468 & 501 & 341 & 353 & 345 & 137 & 29 & 115 & 25 & 156 & 31 & 63 & 13 & 84 & 17 & 112 & 32 \\
\hline 11 & 487 & 501 & 500 & 386 & 415 & 399 & 101 & 21 & 86 & 17 & 101 & 20 & 27 & 6 & 55 & 11 & 57 & 14 \\
\hline 12 & 529 & 521 & 505 & 407 & 430 & 419 & 122 & 23 & 91 & 17 & 86 & 17 & 48 & 9 & 60 & 12 & 42 & 10 \\
\hline 13 & 580 & 575 & 579 & 451 & 469 & 455 & 129 & 22 & 106 & 18 & 124 & 21 & 55 & 10 & 75 & 13 & 80 & 17 \\
\hline 14 & 585 & 576 & 586 & 466 & 486 & 485 & 119 & 20 & 90 & 16 & 101 & 17 & 45 & 8 & 59 & 10 & 57 & 12 \\
\hline 15 & 622 & 604 & 584 & 502 & 528 & 513 & 120 & 19 & 76 & 13 & 71 & 12 & 46 & 7 & 45 & 8 & 27 & 5 \\
\hline 16 & 618 & 603 & 589 & 522 & 562 & 542 & 96 & 16 & 41 & 7 & 47 & 8 & 22 & 4 & 10 & 2 & 3 & 1 \\
\hline 17 & 614 & 579 & 567 & 516 & 548 & 536 & 98 & 16 & 31 & 5 & 31 & 5 & 24 & 4 & 0 & 0 & -13 & -2 \\
\hline 18 & 614 & 577 & 577 & 500 & 527 & 504 & 114 & 19 & 50 & 9 & 73 & 13 & 40 & 7 & 19 & 3 & 29 & 6 \\
\hline 19 & 595 & 555 & 540 & 505 & 533 & 508 & 90 & 15 & 22 & 4 & 32 & 6 & 16 & 3 & -9 & -2 & -12 & -2 \\
\hline 20 & 565 & 532 & 526 & 481 & 515 & 492 & 84 & 15 & 17 & 3 & 34 & 6 & 10 & 2 & -14 & -3 & -10 & -2 \\
\hline 21 & 528 & 507 & 506 & 474 & 505 & 478 & 54 & 10 & 2 & 0 & 28 & 6 & & & & & & \\
\hline 22 & 512 & 499 & 505 & 468 & 500 & 482 & 44 & 9 & -1 & 0 & 23 & 5 & & & & & & \\
\hline 23 & 501 & 492 & 495 & 446 & 474 & 465 & 55 & 11 & 18 & 4 & 30 & 6 & & & & & & \\
\hline 24 & 495 & 482 & 486 & 433 & 461 & 452 & 62 & 13 & 21 & 4 & 34 & 7 & & & & & & \\
\hline $\begin{array}{l}\text { Average for } \\
\text { hours 12-18 }\end{array}$ & 604 & 581 & 575 & 495 & 522 & 506 & 109 & 18 & 59 & 10 & 68 & 12 & 40 & 6.8 & 38 & 6.5 & 32 & 5.6 \\
\hline $\begin{array}{l}\text { Savings for } \\
\text { hours 8-20 }\end{array}$ & & & & & & & & & & & & & 439 & 3.1 & 456 & 3.2 & 499 & 3.7 \\
\hline
\end{tabular}

Notes: The Pre period is for one, two, or three weeks ending at August 18, 2002. The Post period is for one, two or three weeks beginning August 23, 2002. 
Table 31. Kaprielian Brothers Packing Company (Cold Storage) Facility in Reedley: Packing area AC average power demand and savings.

\begin{tabular}{|c|c|c|c|c|c|c|c|c|c|c|c|c|}
\hline \multirow{3}{*}{ Hour } & \multicolumn{3}{|c|}{ Power demand: } & \multicolumn{3}{|c|}{ Power demand: } & \multicolumn{6}{|c|}{ Pre - Post } \\
\hline & \multicolumn{3}{|c|}{\begin{tabular}{l|l}
$21-d a y$ & $14-d a y$
\end{tabular}} & \multirow{2}{*}{$\begin{array}{l}\text { 21-day } \\
\mathrm{kW}\end{array}$} & \multirow{2}{*}{$\begin{array}{l}\text { 14-day } \\
\mathrm{kW}\end{array}$} & \multirow{2}{*}{$\begin{array}{l}\text { 7-day } \\
\mathrm{kW}\end{array}$} & \multicolumn{2}{|c|}{ 21-day } & \multicolumn{2}{|c|}{ 14-day } & \multicolumn{2}{|c|}{ 7-day } \\
\hline & $\mathrm{kW}$ & $\mathrm{kW}$ & $\mathrm{kW}$ & & & & $\mathrm{kW}$ & $\%$ & $\mathrm{~kW}$ & $\%$ & $\mathrm{~kW}$ & $\%$ \\
\hline 1 & 40 & 37 & 27 & 9 & 12 & 16 & 31 & 77 & 25 & 67 & 11 & 41 \\
\hline 2 & 33 & 27 & 14 & 4 & 4 & 5 & 30 & 89 & 23 & 85 & 10 & 68 \\
\hline 3 & 32 & 26 & 14 & 9 & 12 & 16 & 23 & 71 & 14 & 53 & -1 & -10 \\
\hline 4 & 30 & 23 & 8 & 0 & 0 & 0 & 30 & 100 & 23 & 100 & 8 & 100 \\
\hline 5 & 30 & 22 & 7 & 0 & 0 & 0 & 30 & 100 & 22 & 100 & 7 & 100 \\
\hline 6 & 27 & 20 & 7 & 0 & 0 & 0 & 27 & 100 & 20 & 100 & 7 & 100 \\
\hline 7 & 20 & 17 & 8 & 3 & 2 & 2 & 18 & 87 & 14 & 85 & 6 & 74 \\
\hline 8 & 28 & 28 & 36 & 27 & 31 & 22 & 1 & 4 & -3 & -12 & 15 & 41 \\
\hline 9 & 37 & 30 & 48 & 40 & 51 & 43 & -4 & -10 & -20 & -66 & 5 & 10 \\
\hline 10 & 42 & 37 & 62 & 43 & 52 & 46 & -1 & -2 & -15 & -41 & 15 & 25 \\
\hline 11 & 46 & 43 & 59 & 42 & 52 & 45 & 4 & 9 & -9 & -20 & 14 & 24 \\
\hline 12 & 55 & 58 & 62 & 44 & 52 & 49 & 12 & 21 & 5 & 9 & 12 & 20 \\
\hline 13 & 56 & 59 & 64 & 44 & 51 & 49 & 12 & 22 & 8 & 13 & 14 & 22 \\
\hline 14 & 55 & 59 & 61 & 46 & 54 & 50 & 9 & 17 & 5 & 8 & 11 & 18 \\
\hline 15 & 54 & 58 & 58 & 46 & 54 & 48 & 8 & 15 & 3 & 6 & 11 & 18 \\
\hline 16 & 55 & 58 & 57 & 44 & 52 & 47 & 11 & 19 & 6 & 11 & 10 & 18 \\
\hline 17 & 53 & 56 & 56 & 38 & 46 & 40 & 15 & 29 & 9 & 17 & 16 & 28 \\
\hline 18 & 52 & 55 & 50 & 30 & 35 & 29 & 22 & 42 & 20 & 36 & 22 & 43 \\
\hline 19 & 51 & 53 & 49 & 33 & 39 & 41 & 18 & 36 & 14 & 26 & 8 & 15 \\
\hline 20 & 47 & 48 & 44 & 32 & 38 & 45 & 15 & 33 & 9 & 20 & -1 & -2 \\
\hline 21 & 45 & 46 & 40 & 33 & 37 & 45 & 13 & 28 & 8 & 18 & -5 & -12 \\
\hline 22 & 46 & 48 & 38 & 31 & 36 & 44 & 15 & 32 & 12 & 26 & -5 & -13 \\
\hline 23 & 46 & 47 & 38 & 30 & 35 & 43 & 17 & 36 & 12 & 26 & -5 & -14 \\
\hline 24 & 42 & 39 & 30 & 23 & 27 & 32 & 19 & 46 & 13 & 32 & -2 & -8 \\
\hline $\begin{array}{l}\text { Average for } \\
\text { hours 12-18 }\end{array}$ & 54 & 57 & 57 & 40 & 48 & 43 & 14 & 26 & 9 & 16 & 13 & 23 \\
\hline
\end{tabular}

Notes: The Pre period is for one, two, or three weeks ending at August 18, 2002. The Post period is for one, two or three weeks beginning August 23, 2002. 

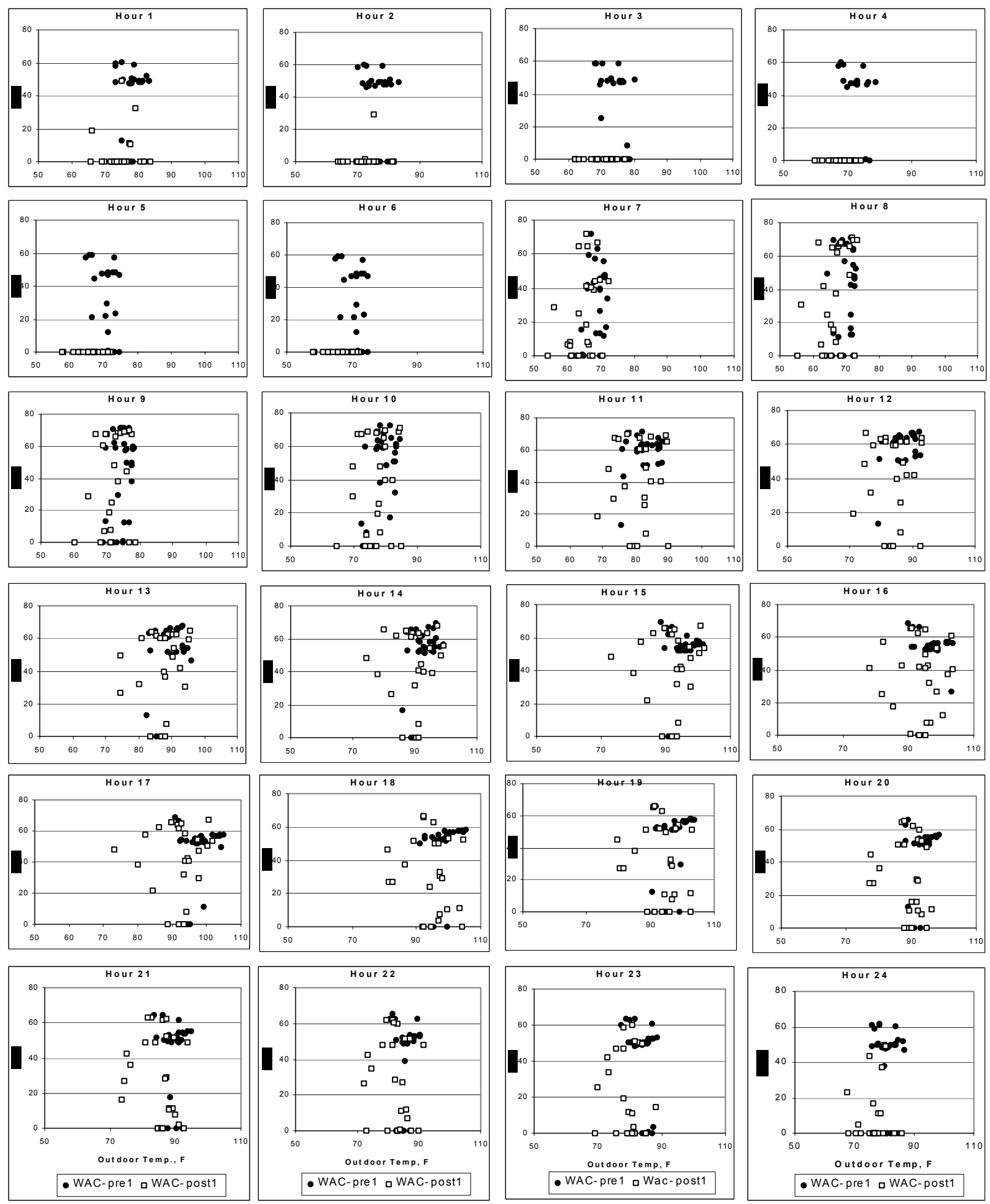

Figure 55. Kaprielian Brothers Packing Company (Cold Storage) Facility in Reedley: Electrical demand as a function of outdoor temperature for packing area AC. 


\section{Estimate of Peak Electricity Demand and Savings Using 2002 (pre) and 2003 (post) data}

Peak-Demand Cooling Electricity Savings for Cold Storage Areas, Conditioning Room, and Palletizing Room. Figure 56 shows the hourly electricity demand data for chillers (T1) during the Pre02 period and Post03 period. We also calculated the average hourly demands for the hours 12 to 18 (see Table 32). During hours 12 to 18, the difference between the average chiller (T1) hourly electricity demand for Pre02 and Post03 period was about 80-140 kW. The hourly electricity demand averaged for hours 12-18 was reduced by $101 \mathrm{~kW}(17 \%)$. The areanormalized estimated 'savings' is about $1.5 \mathrm{~W} / \mathrm{ft}^{2}$.

We adjusted for the bias in chiller electricity demand as discussed earlier. The average difference between the Pre02 and Post03 periods for nighttime hours 9 pm to 3 am was about 69 $\mathrm{kW}$. In order to estimate the savings associated with installation of cool roofs, we subtracted this $69 \mathrm{~kW}$ from the difference of the Pre02 and Post03 chiller power demand for all hours. This resulted in average peak demand savings (for hours 12-18) of $32 \mathrm{~kW} \mathrm{(5 \% ).} \mathrm{The} \mathrm{estimated}$ normalized peak-demand savings is $0.5 \mathrm{~W} / \mathrm{ft}^{2}$. This approach also yielded a net daily energy savings of $360 \mathrm{kWh}(3 \%)$; corresponding to a normalized savings of about $5.3 \mathrm{Wh} / \mathrm{ft}^{2}$. These estimates of savings compares well with the estimate of savings using the 2002 data alone.

Cooling Electricity Demand for Package Area 1. Figure 57 shows the hourly electricity demand data for AC. For the Post03 period, the data clearly shows significant energy use by the AC systems during the nighttime hours. However, the analysis of hourly demand during Pre02 and Post03 did not show measurable savings.

\section{Simulated Air Conditioning Energy Use and Savings}

We unsuccessfully spent significant amount of time trying to simulate this cold storage facility with DOE-2.1E. The current scientific version of DOE-2.1E has significant limitations in simulating ammonia chillers and simulating conditioning zones below $55^{\circ} \mathrm{F}$. (The highlights of the input for the DOE-2 simulations are summarized in Table 33. Hence, we extrapolated electricity use and peak demand savings for other months and other climate regions by correlating savings with insolation (c.f. Methodology, p.11).

We used Eq. (4) to estimate the chillers' cooling energy and peak-demand savings for other months of the years (see Table 34). These estimates assume the same operation schedules for all months. The solar data were obtained from the CTZ13 (Fresno, CA) weather tape. The estimated peak demand savings during months of June and July is about $0.5 \mathrm{~W} / \mathrm{ft}^{2}\left(5 \mathrm{~W} / \mathrm{m}^{2}\right)$. The daily average savings for these months are about $6 \mathrm{Wh} / \mathrm{ft}^{2}\left(65 \mathrm{Wh} / \mathrm{m}^{2}\right)$. The total annual energy savings (assuming full operational schedule during the year) is about $1.4 \mathrm{kWh} / \mathrm{ft}^{2}(15$ $\mathrm{kWh} / \mathrm{m}^{2}$ ). Obviously, this is an upper bound to the savings, since the operation of this cold storage facility is highly seasonal. To estimate a lower bound for savings, we assumed that the chillers are only fully operational from mid-May to mid-September (4 months). The chillers' energy savings estimates for this high-season summer period is $0.64 \mathrm{kWh} / \mathrm{ft}^{2}\left(6.9 \mathrm{kWh} / \mathrm{m}^{2}\right)$. 

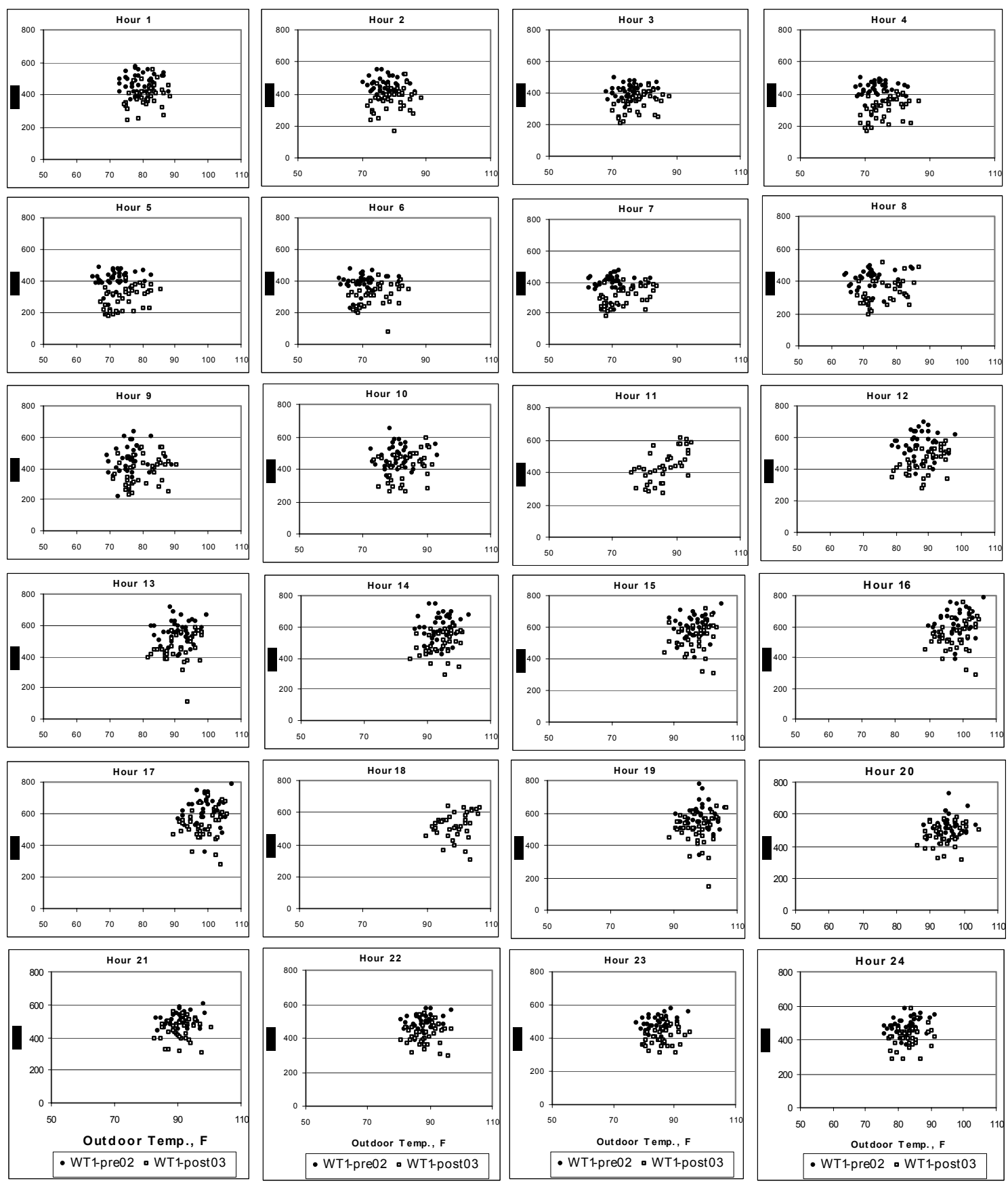

Figure 56. Kaprielian Brothers Packing Company (Cold Storage) Facility in Reedley: Chiller electrical demand for 2002 Pre-period and 2003 Post-period. "Pre" period is from July 11 to August 18, 2002 and "Post: 03Summer" period is from June 28 to August 18, 2003. 
Table 32. Kaprielian Brothers Packing Company (Cold Storage) Facility in Reedley: Chiller average power demand and savings.

\begin{tabular}{|c|c|c|c|c|c|c|}
\hline \multirow{2}{*}{ Hour } & \multirow{2}{*}{$\begin{array}{l}\text { Power } \\
\text { demand: } \\
\text { Pre (average) } \\
\qquad \text { kW }\end{array}$} & \multirow{2}{*}{$\begin{array}{l}\text { Power } \\
\text { demand: Post } \\
\text { (average) } \\
\qquad \mathrm{kW}\end{array}$} & \multicolumn{2}{|c|}{ Pre - Post } & \multicolumn{2}{|c|}{$\begin{array}{l}\text { (Pre - Post) - } \\
\text { (nighttime bias) }\end{array}$} \\
\hline & & & $\mathrm{kW}$ & $\%$ & $\mathrm{~kW}$ & $\%$ \\
\hline 1 & 477 & 403 & 74 & 16 & & \\
\hline 2 & 456 & 368 & 88 & 19 & & \\
\hline 3 & 418 & 350 & 68 & 16 & & \\
\hline 4 & 431 & 308 & 122 & 28 & 53 & 12 \\
\hline 5 & 424 & 292 & 131 & 31 & 62 & 15 \\
\hline 6 & 398 & 303 & 95 & 24 & 25 & 6 \\
\hline 7 & 391 & 299 & 91 & 23 & 22 & 6 \\
\hline 8 & 413 & 302 & 111 & 27 & 42 & 10 \\
\hline 9 & 447 & 349 & 97 & 22 & 28 & 6 \\
\hline 10 & 473 & 392 & 81 & 17 & 12 & 3 \\
\hline 11 & 507 & 393 & 115 & 23 & 46 & 9 \\
\hline 12 & 556 & 414 & 142 & 26 & 73 & 13 \\
\hline 13 & 556 & 438 & 117 & 21 & 48 & 9 \\
\hline 14 & 593 & 474 & 119 & 20 & 50 & 8 \\
\hline 15 & 598 & 522 & 76 & 13 & 7 & 1 \\
\hline 16 & 616 & 530 & 86 & 14 & 17 & 3 \\
\hline 17 & 620 & 531 & 89 & 14 & 19 & 3 \\
\hline 18 & 601 & 521 & 80 & 13 & & 2 \\
\hline 19 & 569 & 503 & 65 & 11 & & \\
\hline 20 & 536 & 487 & 49 & 9 & & \\
\hline 21 & 514 & 459 & 55 & 11 & & \\
\hline 22 & 502 & 430 & 72 & 14 & & \\
\hline 23 & 499 & 420 & 79 & 16 & & \\
\hline 24 & 350 & 427 & 68 & 14 & & \\
\hline $\begin{array}{l}\text { Average } \\
\text { for hours } \\
12-18\end{array}$ & 591 & 490 & 101 & 17 & 32 & 5 \\
\hline
\end{tabular}

Notes: The Pre and Post periods are July 11 to August 18, 2002 and 2003, respectively. Data are normalized for changes for the average hourly outdoor temperature. 

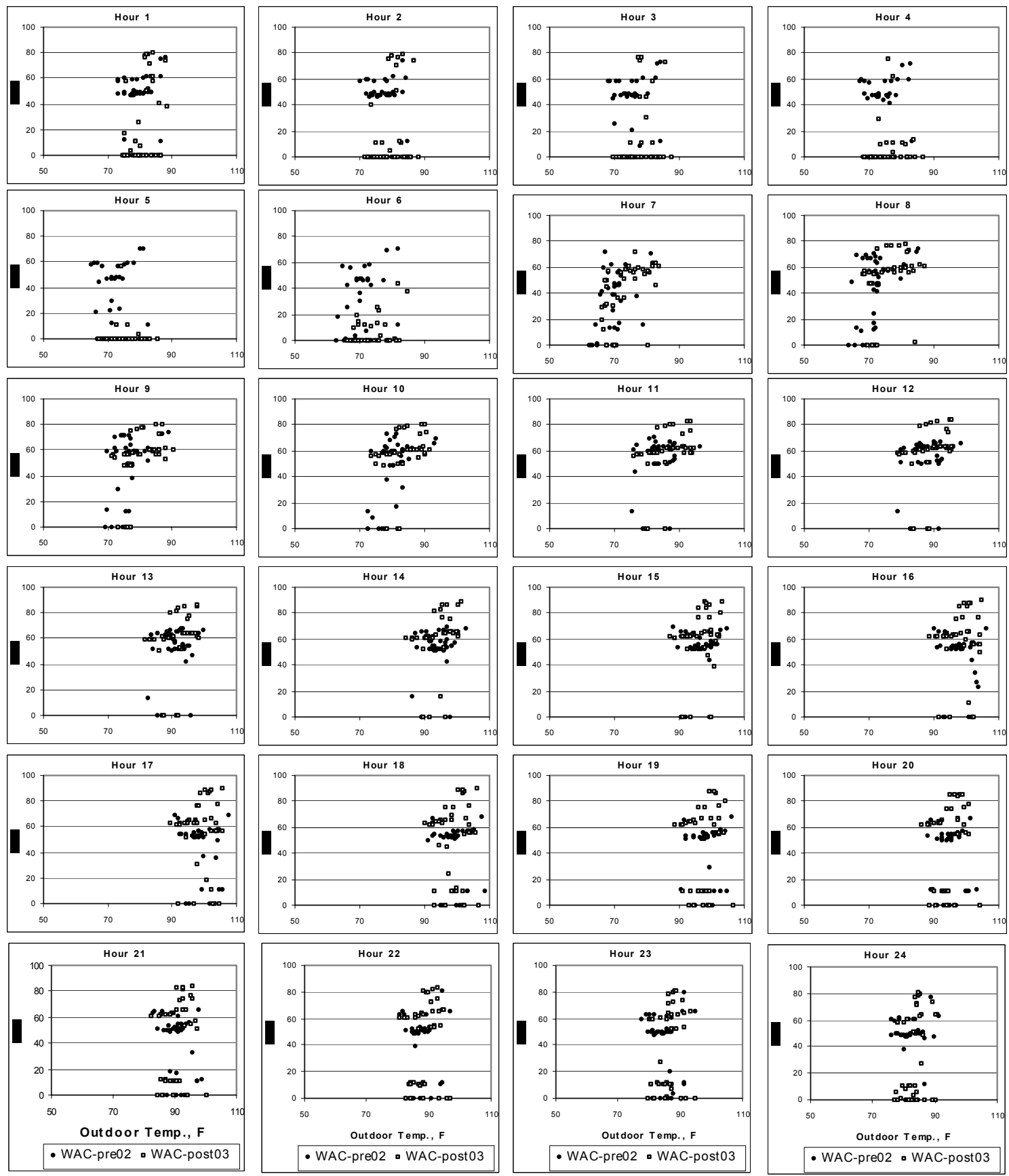

Figure 57. Kaprielian Brothers Packing Company (Cold Storage) facility in Reedley: Packing area A/C electrical demand for 2002 Pre-period and 2003 Post-period. "Pre" period is from July 11 to August 18, 2002 and "Post: 03Summer" period is from July 11 to August 18, 2003. 
Table 33. Kaprielian Brothers Packing Company (Cold Storage) facility in Reedley: Building description.

\begin{tabular}{|c|c|c|}
\hline \multicolumn{3}{|l|}{ General } \\
\hline & Cold Storage Warehouse And Packing Facility & $103000 \mathrm{ft}^{2}$ \\
\hline & Orientation & $\mathrm{N}\left(0^{\circ}\right)$ \\
\hline & North/South & $588.75^{\prime}$ \\
\hline & East/West & $279.5^{\prime}$ \\
\hline & Location & Fresno, $\mathrm{Ca}$ \\
\hline & Weather Site & Ctz13 \\
\hline \multicolumn{3}{|l|}{ Zones } \\
\hline & Cold Storage (West) & $36100 \mathrm{ft}^{2}\left[30^{\prime}\right]$ \\
\hline & Cold Storage (East) & $8400 \mathrm{ft}^{2}\left[30^{\prime}\right]$ \\
\hline & Packing (Conditioned $23711 \mathrm{Ft}^{2}$ ) & $36200 \mathrm{ft}^{2}\left[30^{\prime}\right]$ \\
\hline & Conditioning & $5900 \mathrm{ft}^{2}\left[30^{\prime}\right]$ \\
\hline & Palletizing & $7900 \mathrm{ft}^{2}\left[30^{\prime}\right]$ \\
\hline & Hallway (Unconditioned) & $8300 \mathrm{ft}^{2}\left[30^{\prime}\right]$ \\
\hline \multicolumn{3}{|c|}{ Roof Construction } \\
\hline & Cold Storage (West) & \\
\hline & Black Epdm & Pre-retrofit \\
\hline & White Elastomeric Coating Over Membrane & Post-retrofit \\
\hline & Wood Deck & \\
\hline & Polyiso Foam $2.5^{\prime \prime}$ & $\mathrm{R}-12$ \\
\hline & Cold Storage (East) & \\
\hline & Metal Roof Standing Seam & Pre-retrofit \\
\hline & White Elastomeric Coating Over Metal Roof & Post-retrofit \\
\hline & Polyiso Foam 6" & R-29 \\
\hline & Conditioning & \\
\hline & Galvalum Standing Seam & Pre-Retrofit \\
\hline & White Elastomeric Coating Over Metal Roof & Post-Retrofit \\
\hline
\end{tabular}




\begin{tabular}{|c|c|c|}
\hline & Fiberglass Batt 2.5" & R-8 \\
\hline & Plenum & $5^{\prime}$ \\
\hline & Polystyrene Foam 6" & $\mathrm{R}-25$ \\
\hline & Packing, Palletizing & \\
\hline & Galvalum Standing Seam & Pre-retrofit \\
\hline & White Elastomeric Coating Over Metal Roof & Post-retrofit \\
\hline & Fiberglass Batt 2.5" & $\mathrm{R}-8$ \\
\hline \multirow{8}{*}{ Roof Solar Reflectance } & Cold Storage West & \\
\hline & Pre-Retrofit & 0.04 \\
\hline & Post-Retrofit (Initial) & 0.75 \\
\hline & Post-Retrofit (10 Months) & 0.62 \\
\hline & $\begin{array}{l}\text { Cold Storage East, Packing, Conditioning, } \\
\text { Palletizing }\end{array}$ & \\
\hline & Pre-Retrofit & 0.30 \\
\hline & Post-Retrofit (Initial) & 0.75 \\
\hline & Post-Retrofit (2 Months) & 0.63 \\
\hline \multicolumn{3}{|l|}{$\begin{array}{l}\text { Roof Thermal } \\
\text { Emittance }\end{array}$} \\
\hline & Pre-Retrofit (Cold Storage West) & 0.90 \\
\hline & $\begin{array}{l}\text { Pre-Retrofit (Packing, Cold Storage East, } \\
\text { Conditioning) }\end{array}$ & 0.30 \\
\hline & Post-Retrofit (All) & 0.90 \\
\hline \multicolumn{3}{|l|}{ Wall Construction } \\
\hline & Cold Storage (West) & \\
\hline & Concrete & $8^{\prime \prime}$ \\
\hline & Polyiso Foam & $2.5^{\prime \prime}$ \\
\hline & Cold Storage (East) & \\
\hline & Metal & \\
\hline & Polyiso Foam & $6 "$ \\
\hline
\end{tabular}




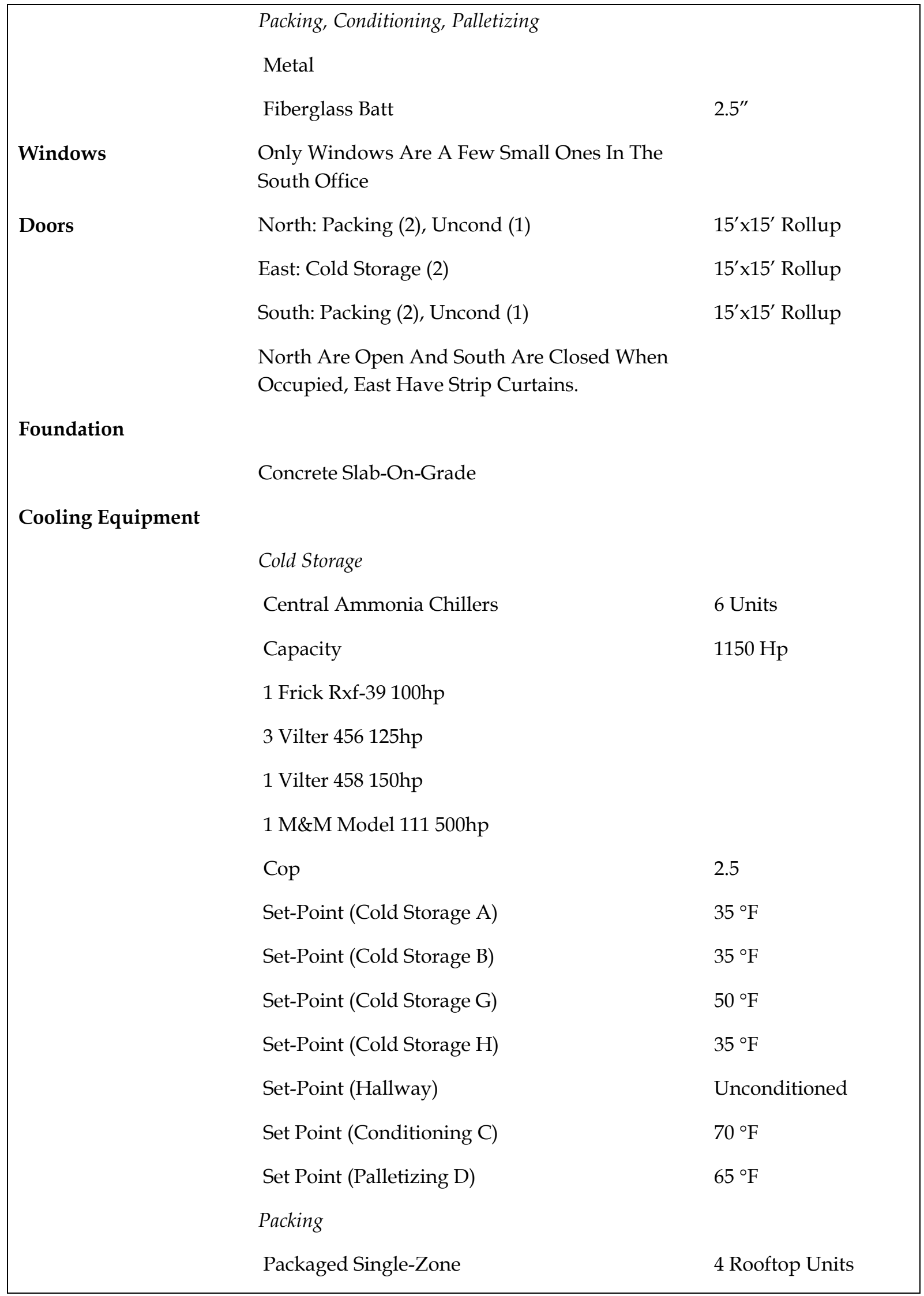




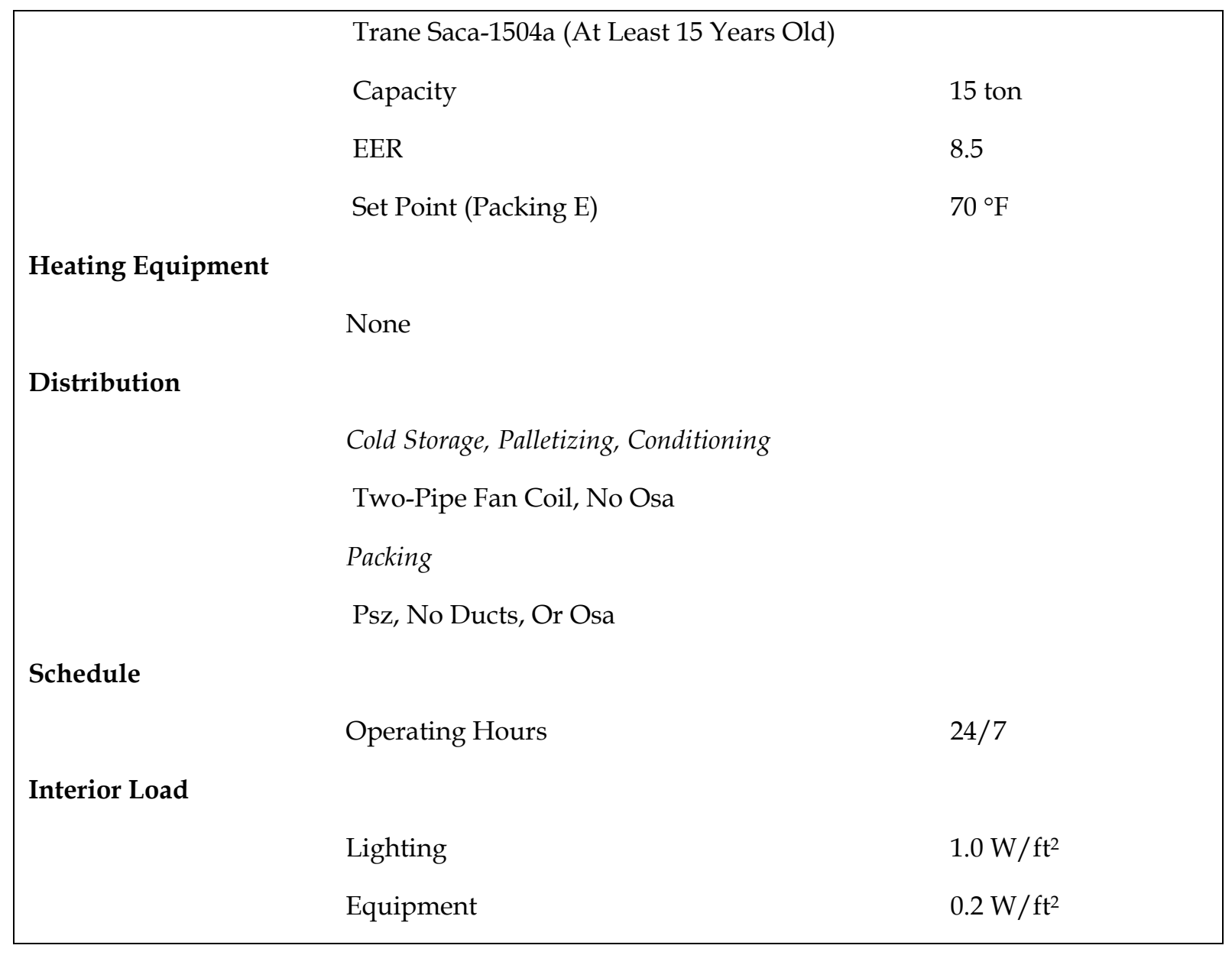


Table 34. Kaprielian Brothers Packing Company (Cold Storage) facility in Reedley: Average monthly chillers cooling electricity and peak-demand savings.

\begin{tabular}{|l|c|c|c|c|c|c|c|c|c|c|c|c|}
\hline & Jan. & Feb. & Mar. & Apr. & May & June & July & Aug. & Sep. & Oct. & Nov. & Dec. \\
\hline $\begin{array}{l}\text { Solar Flux } \\
\text { (Wh/ft } 2 \text { day) }\end{array}$ & 334 & 491 & 719 & 878 & 1025 & 1086 & 1094 & 971 & 896 & 703 & 492 & 284 \\
Energy savings & & & & & & & & & & & & \\
kWh/day & 114 & 167 & 245 & 299 & 349 & 370 & 372 & 330 & 305 & 239 & 167 & 97 \\
Wh/ft2/day & 1.7 & 2.5 & 3.7 & 4.5 & 5.2 & 5.5 & 5.6 & 4.9 & 4.6 & 3.6 & 2.5 & 1.4 \\
Peak-demand savings & & & & & & & & & & & \\
kW & 12 & 17 & 25 & 30 & 36 & 38 & 38 & 34 & 31 & 24 & 17 & 10 \\
Wh/ft 2 & 0.2 & 0.3 & 0.4 & 0.5 & 0.5 & 0.6 & 0.6 & 0.5 & 0.5 & 0.4 & 0.3 & 0.1 \\
\hline
\end{tabular}

Notes: The estimates assume the same operational schedules for all months. The solar data were obtained from the CTZ13 (Fresno, CA) weather tape.

Assuming an average cost of $\$ 0.10 / \mathrm{kWh}$, the four-month energy savings is estimated at 0.07 $\$ / \mathrm{ft}^{2}\left(0.7 \$ / \mathrm{m}^{2}\right)$. The peak-demand savings during this period is $0.5 \mathrm{~W} / \mathrm{ft}^{2}\left(5 \mathrm{~W} / \mathrm{m}^{2}\right)$. Assuming a monthly peak-demand charge of $\$ 20 / \mathrm{kW}$, the estimated mid-May to mid-September peakdemand savings is [4(month)] $\times\left[\$ 20 / \mathrm{kW} /(\right.$ month) $] \times\left[0.5 \mathrm{~W} / \mathrm{ft}^{2}\right] \times[1 / 1000 \mathrm{~kW} / \mathrm{W}]=\$ 0.04 / \mathrm{ft}^{2}$ $\left(\$ 0.40 / \mathrm{m}^{2}\right)$. The total 4-month savings is then $\$ 0.11 / \mathrm{ft}^{2}\left(\$ 1.1 / \mathrm{m}^{2}\right)$.

\section{Estimated Savings for Other California Climate Zones}

Using the solar data as an indicator (see Table 35), we estimated the average daily energy and peak demand savings for all 16 California climate zones. These savings are shown in Table 36 and Table 37. The chillers' energy savings estimates for mid-May to mid-September highseason summer period ranges from 0.4 to $0.7 \mathrm{kWh} / \mathrm{ft}^{2}\left(4.2\right.$ to $\left.6.9 \mathrm{kWh} / \mathrm{m}^{2}\right)$. Assuming an average cost of $\$ 0.10 / \mathrm{kWh}$, the estimates of energy savings ranges from $0.04-0.07 \$ / \mathrm{ft}^{2}\left(\$ 0.4 / \mathrm{m}^{2}\right.$ to $\$ 0.7 / \mathrm{m}^{2}$ ). The peak-demand savings during this period ranges from 0.33 to $0.54 \mathrm{~W} / \mathrm{ft}^{2}$ ( 3.5 to $\left.5.8 \mathrm{~W} / \mathrm{m}^{2}\right)$. Assuming a monthly peak-demand charge of $\$ 20 / \mathrm{kW}$, the estimated mid-May to mid-September peak-demand savings is $[4$ (month) $] \times[\$ 20 / \mathrm{kW} /$ (month) $] \times[0.33$ $\left.0.54 \mathrm{~W} / \mathrm{ft}^{2}\right] \times[1 / 1000 \mathrm{~kW} / \mathrm{W}]=0.026-0.043 / \mathrm{ft}^{2}\left(0.28-0.46 / \mathrm{m}^{2}\right)$. The total 4 -month savings ranges from 0.07 to $0.11 \$ / \mathrm{ft}^{2}\left(0.7\right.$ to $\left.1.1 \$ / \mathrm{m}^{2}\right)$. 
Table 35. Average daily insolation $\left(\mathrm{Wh} / \mathrm{ft}^{2}\right)$ data for all California climate zones.

\begin{tabular}{|c|r|r|r|r|r|r|r|r|r|r|r|r|}
\hline CTZ & Jan. & Feb. & Mar. & Apr. & May & June & July & Aug. & Sep. & Oct. & Nov. & Dec. \\
\hline 1 & 293 & 370 & 423 & 644 & 696 & 673 & 643 & 561 & 519 & 436 & 254 & 267 \\
\hline 2 & 516 & 373 & 567 & 811 & 713 & 953 & 895 & 774 & 726 & 602 & 407 & 298 \\
\hline 3 & 370 & 499 & 591 & 808 & 837 & 875 & 840 & 798 & 692 & 547 & 418 & 368 \\
\hline 4 & 408 & 529 & 663 & 766 & 880 & 927 & 917 & 854 & 712 & 565 & 430 & 336 \\
\hline 5 & 477 & 507 & 660 & 750 & 741 & 882 & 866 & 800 & 662 & 630 & 522 & 473 \\
\hline 6 & 549 & 601 & 719 & 757 & 774 & 772 & 844 & 805 & 694 & 571 & 518 & 495 \\
\hline 7 & 530 & 610 & 699 & 742 & 706 & 701 & 782 & 772 & 643 & 616 & 534 & 511 \\
\hline 8 & 577 & 610 & 726 & 760 & 764 & 812 & 872 & 791 & 672 & 607 & 539 & 500 \\
\hline 9 & 628 & 757 & 692 & 674 & 675 & 725 & 881 & 727 & 707 & 609 & 479 & 528 \\
\hline 10 & 592 & 816 & 767 & 720 & 698 & 731 & 840 & 746 & 719 & 566 & 486 & 655 \\
\hline 11 & 318 & 456 & 601 & 825 & 955 & 1017 & 1098 & 974 & 844 & 642 & 406 & 288 \\
\hline 12 & 330 & 456 & 657 & 842 & 979 & 1079 & 1084 & 979 & 860 & 648 & 481 & 297 \\
\hline 13 & 334 & 491 & 719 & 878 & 1025 & 1086 & 1094 & 971 & 896 & 703 & 492 & 284 \\
\hline 14 & 499 & 670 & 759 & 969 & 1042 & 1114 & 1047 & 975 & 871 & 698 & 549 & 490 \\
\hline 15 & 673 & 677 & 796 & 898 & 820 & 990 & 796 & 818 & 809 & 732 & 607 & 567 \\
\hline 16 & 327 & 412 & 578 & 733 & 864 & 948 & 1033 & 903 & 787 & 569 & 319 & 300 \\
\hline
\end{tabular}

Notes: The solar data were obtained from the CTZ weather tapes. 

Table 36. Extrapolation of energy savings for cold storages in other climate regions in California.

\begin{tabular}{|c|c|c|c|c|c|c|c|c|c|c|c|c|c|c|}
\hline CTZ & Jan. & Feb. & Mar. & Apr. & May & June & July & Aug. & Sep. & Oct. & Nov. & Dec. & $\begin{array}{c}\text { Total } \\
\left(\mathrm{kWh} / \mathrm{ft}^{2} / \text { year }\right)\end{array}$ & $\begin{array}{l}\text { May-Sep } \\
\left(\mathrm{kWh} / \mathrm{ft}^{2}\right)\end{array}$ \\
\hline 1 & 1.5 & 1.9 & 2.2 & 3.3 & 3.5 & 3.4 & 3.3 & 2.9 & 2.6 & 2.2 & 1.3 & 1.4 & 0.9 & 0.4 \\
\hline 3 & 1.9 & 2.5 & 3.0 & 4.1 & 4.3 & 4.5 & 4.3 & 4.1 & 3.5 & 2.8 & 2.1 & 1.9 & 1.2 & 0.5 \\
\hline 4 & 2.1 & 2.7 & 3.4 & 3.9 & 4.5 & 4.7 & 4.7 & 4.4 & 3.6 & 2.9 & 2.2 & 1.7 & 1.2 & 0.5 \\
\hline 6 & 2.8 & 3.1 & 3.7 & 3.9 & 3.9 & 3.9 & 4.3 & 4.1 & 3.5 & 2.9 & 2.6 & 2.5 & 1.3 & 0.5 \\
\hline 7 & 2.7 & 3.1 & 3.6 & 3.8 & 3.6 & 3.6 & 4.0 & 3.9 & 3.3 & 3.1 & 2.7 & 2.6 & 1.2 & 0.5 \\
\hline 8 & 2.9 & 3.1 & 3.7 & 3.9 & 3.9 & 4.1 & 4.4 & 4.0 & 3.4 & 3.1 & 2.7 & 2.6 & 1.3 & 0.5 \\
\hline 12 & 1.7 & 2.3 & 3.4 & 4.3 & 5.0 & 5.5 & 5.5 & 5.0 & 4.4 & 3.3 & 2.5 & 1.5 & 1.4 & 0.6 \\
\hline 13 & 1.7 & 2.5 & 3.7 & 4.5 & 5.2 & 5.5 & 5.6 & 4.9 & 4.6 & 3.6 & 2.5 & 1.4 & 1.4 & 0.6 \\
\hline 14 & 2.5 & 3.4 & 3.9 & 4.9 & 5.3 & 5.7 & 5.3 & 5.0 & 4.4 & 3.6 & 2.8 & 2.5 & 1.5 & 0.6 \\
\hline 15 & 3.4 & 3.5 & 4.1 & 4.6 & 4.2 & 5.0 & 4.1 & 4.2 & 4.1 & 3.7 & 3.1 & 2.9 & 1.4 & 0.5 \\
\hline 16 & 1.7 & 2.1 & 2.9 & 3.7 & 4.4 & 4.8 & 5.3 & 4.6 & 4.0 & 2.9 & 1.6 & 1.5 & 1.2 & 0.6 \\
\hline
\end{tabular}

Notes: Average monthly chillers cooling electricity savings ( $\mathrm{Wh} / \mathrm{ft} 2 /$ day). The estimates assume the same operational schedules for all months. The solar data were obtained from the CTZ weather tapes. The table also shows the annual total and mid-May to mid-September total savings. 
Table 37. Extrapolation of peak-demand savings for cold storages in other climate regions in California.

\begin{tabular}{|c|c|c|c|c|c|c|c|c|c|c|c|c|}
\hline CTZ & Jan. & Feb. & Mar. & Apr. & May & June & July & Aug. & Sep. & Oct. & Nov. & Dec. \\
\hline 1 & 0.2 & 0.2 & 0.2 & 0.3 & 0.4 & 0.3 & 0.3 & 0.3 & 0.3 & 0.2 & 0.1 & 0.1 \\
\hline 2 & 0.3 & 0.2 & 0.3 & 0.4 & 0.4 & 0.5 & 0.5 & 0.4 & 0.4 & 0.3 & 0.2 & 0.2 \\
\hline 3 & 0.2 & 0.3 & 0.3 & 0.4 & 0.4 & 0.5 & 0.4 & 0.4 & 0.4 & 0.3 & 0.2 & 0.2 \\
\hline 4 & 0.2 & 0.3 & 0.3 & 0.4 & 0.5 & 0.5 & 0.5 & 0.4 & 0.4 & 0.3 & 0.2 & 0.2 \\
\hline 5 & 0.2 & 0.3 & 0.3 & 0.4 & 0.4 & 0.5 & 0.5 & 0.4 & 0.3 & 0.3 & 0.3 & 0.2 \\
\hline 6 & 0.3 & 0.3 & 0.4 & 0.4 & 0.4 & 0.4 & 0.4 & 0.4 & 0.4 & 0.3 & 0.3 & 0.3 \\
\hline 7 & 0.3 & 0.3 & 0.4 & 0.4 & 0.4 & 0.4 & 0.4 & 0.4 & 0.3 & 0.3 & 0.3 & 0.3 \\
\hline 8 & 0.3 & 0.3 & 0.4 & 0.4 & 0.4 & 0.4 & 0.5 & 0.4 & 0.3 & 0.3 & 0.3 & 0.3 \\
\hline 9 & 0.3 & 0.4 & 0.4 & 0.4 & 0.4 & 0.4 & 0.5 & 0.4 & 0.4 & 0.3 & 0.2 & 0.3 \\
\hline 10 & 0.3 & 0.4 & 0.4 & 0.4 & 0.4 & 0.4 & 0.4 & 0.4 & 0.4 & 0.3 & 0.3 & 0.3 \\
\hline 11 & 0.2 & 0.2 & 0.3 & 0.4 & 0.5 & 0.5 & 0.6 & 0.5 & 0.4 & 0.3 & 0.2 & 0.1 \\
\hline 12 & 0.2 & 0.2 & 0.3 & 0.4 & 0.5 & 0.6 & 0.6 & 0.5 & 0.4 & 0.3 & 0.3 & 0.2 \\
\hline 13 & 0.2 & 0.3 & 0.4 & 0.5 & 0.5 & 0.6 & 0.6 & 0.5 & 0.5 & 0.4 & 0.3 & 0.1 \\
\hline 14 & 0.3 & 0.3 & 0.4 & 0.5 & 0.5 & 0.6 & 0.5 & 0.5 & 0.5 & 0.4 & 0.3 & 0.3 \\
\hline 15 & 0.3 & 0.4 & 0.4 & 0.5 & 0.4 & 0.5 & 0.4 & 0.4 & 0.4 & 0.4 & 0.3 & 0.3 \\
\hline 16 & 0.2 & 0.2 & 0.3 & 0.4 & 0.4 & 0.5 & 0.5 & 0.5 & 0.4 & 0.3 & 0.2 & 0.2 \\
\hline
\end{tabular}

Notes: Average monthly chillers cooling peak-demand savings (W/ft $\left.{ }^{2}\right)$. The estimates assume the same operational schedules for all months. The solar data were obtained from the CTZ weather tapes. 


\subsection{Summary, Conclusions, and Recommendations}

\subsection{Summary}

In this study, we selected several buildings for monitoring, collected data on roof performance, and documented both energy and peak demand savings resulted from installation of cool roofs. The elements of the study included:

- selection of buildings to monitor

- design of monitoring system for the selected buildings

- $\quad$ specification, procurement, installation, commissioning, and maintenance of monitoring system

- base-case data collection, review, analysis and troubleshooting

- coordination during the installation of cool roofs

- cool roof data collection, review, analysis and troubleshooting

- estimation of electricity and peak demand savings; and

- extrapolation of savings to other California climate zones.

The selection of candidate buildings for monitoring started by interviewing (via telephone) the contacts for about 250 buildings identified through (a) data mining or (b) leads provided by contractors and other helpful individuals. A small number of buildings (about a dozen) appeared sufficiently promising to warrant a half-day site visit by our subcontracted engineer. The engineer surveyed the building's layout, construction, contents, operation, and cooling equipment; reviewed past utility bills; took photographs; and later prepared a brief report to be evaluated by LBNL.

Buildings that in LBNL's technical evaluation "passed" the site visit were considered suitable for monitoring. Once we obtained tentative agreement to participate from the building's owner or manager, we submitted a recommendation for inclusion to our program manager at the California Energy Commission. Once approved, the monitoring process could begin.

We eventually recruited six buildings: a retail store in Sacramento; an elementary school in San Marcos (near San Diego); an office building in Irvine; and a cold storage facility in Reedley (near Fresno) that included a cold storage building, a conditioning and fruit-palletizing area, a conditioned packing area, and two unconditioned packing areas.

For each site, we developed a monitoring protocol and specified, procured, installed, and commissioned the monitoring system. Typical monitoring points included roof surface temperatures, roof underside temperatures, indoor and plenum air temperatures, heat flux through the roof, weather conditions, incoming solar radiation, cooling electricity use, and total electricity use. The monitored data were collected at 15-minute intervals.

The first step in the analysis was to aggregate the validated 15-minute data into hourly and daily values. This was done for solar intensity, cooling electricity use, and total building 
electricity use. The temperature data were averaged to yield hourly and daily variables. In this process, questionable and missing data were identified and excluded from the analysis.

The parameters that can affect air-conditioning electricity use include outside temperature, inside temperature, solar heat gain, internal loads, relative humidity, and wind speed. A systematic regression analysis was performed in order to determine the sensitivity of the airconditioning electricity use to these environmental parameters. The analysis was performed for the initial conditions before the roof was coated with a reflective white coating (Pre period) and for the conditions after the roof was coated (Post period). These regressions allowed normalizing the Pre and Post conditions for all parameters before making an attempt to estimate savings from the application of white coating.

\subsection{Conclusions}

In the retail store building in Sacramento, the maximum surface temperature elevation was reduced by about $60-65^{\circ} \mathrm{F}$ after coating the roof, and the under-roof temperature in the conditioned area was reduced by as much as $40-50^{\circ} \mathrm{F}$. For the period of August 8 to September 30,2002 , the estimated savings in average air conditioning energy use were about $83 \mathrm{kWh} /$ day $(52 \% ; 6.7 \mathrm{Wh} /$ day per square foot of conditioned area). On hot days when the afternoon temperature was above $100^{\circ} \mathrm{F}$, the measured savings in average peak demand for peak hours (hours 12-17) were about 12-13 kW (about $1 \mathrm{~W}$ per square foot of conditioned area).

In the school building in San Marcos, the reductions in the maximum surface temperature and under-roof temperature were about the same as for the retail store. For the period of July 8 to August 20, 2002, the estimated savings in average air conditioning energy use were about 22-26 $\mathrm{kWh} /$ day $(17-18 \% ; 3.9-4.5 \mathrm{Wh} /$ day per square foot of conditioned area). On hot days when the afternoon temperature was above $90^{\circ} \mathrm{F}$, the measured savings in average peak demand for hours 10-16 were about $3.1 \mathrm{~kW}$ (about $0.5 \mathrm{~W}$ per square foot of conditioned area).

In the cold storage facility in Reedley, the maximum surface temperature elevation was reduced by about $65-75^{\circ} \mathrm{F}$ after coating the roof. The under-roof and inside temperatures closely followed each other at about $32-35^{\circ} \mathrm{F}$. For the period of July 11 to September 14, 2002, and July 11 to August 18, 2003, the estimated savings in average chiller energy use were about 360-500 $\mathrm{kWh} /$ day $(3-4 \% ; 5.3-7.5 \mathrm{Wh} /$ day per square foot of conditioned area). On hot days when the afternoon temperature was above $100^{\circ} \mathrm{F}$, the measured savings in average peak demand for peak hours (hours 12-18) where about 32-40 kW (about 0.5-0.6 W per square foot of conditioned area).

Using the measured data and calibrated simulations, we estimated savings for similar buildings for all California 16 climate zones (see Table 38). 
Table 38. Estimated annual energy savings and peak demand reduction in July.

\begin{tabular}{|c|c|c|c|c|c|c|}
\hline \multirow{2}{*}{ CTZ } & \multicolumn{2}{|c|}{ Retail Storea $^{2}$} & \multicolumn{2}{c|}{ School Buildingb } & \multicolumn{2}{c|}{ Cold Storage Facilityc } \\
\cline { 2 - 7 } & $\mathrm{kWh} / \mathrm{ft}^{2}$ & $\mathrm{~W} / \mathrm{ft}^{2}$ & $\mathrm{kWh} / \mathrm{ft}^{2}$ & $\mathrm{~W} / \mathrm{ft}^{2}$ & $\mathrm{kWh} / \mathrm{ft}^{2}$ & $\mathrm{~W} / \mathrm{ft}^{2}$ \\
\hline 1 & 0.06 & 0.06 & 0.10 & 0.24 & 0.42 & 0.36 \\
\hline 2 & 1.07 & 0.46 & 0.39 & 0.36 & 0.56 & 0.50 \\
\hline 3 & 0.37 & 0.27 & 0.34 & 0.30 & 0.55 & 0.47 \\
\hline 4 & 0.98 & 0.43 & 0.47 & 0.33 & 0.59 & 0.51 \\
\hline 5 & 0.55 & 0.32 & 0.28 & 0.30 & 0.55 & 0.48 \\
\hline 6 & 1.04 & 0.40 & 0.47 & 0.26 & 0.53 & 0.47 \\
\hline 7 & 0.92 & 0.33 & 0.48 & 0.25 & 0.49 & 0.44 \\
\hline 8 & 1.18 & 0.43 & 0.57 & 0.32 & 0.54 & 0.49 \\
\hline 9 & 1.10 & 0.40 & 0.50 & 0.31 & 0.51 & 0.49 \\
\hline 10 & 1.42 & 0.50 & 0.54 & 0.35 & 0.51 & 0.47 \\
\hline 11 & 1.00 & 0.45 & 0.42 & 0.33 & 0.67 & 0.61 \\
\hline 12 & 1.00 & 0.46 & 0.43 & 0.34 & 0.69 & 0.61 \\
\hline 13 & 1.29 & 0.54 & 0.49 & 0.35 & 0.69 & 0.61 \\
\hline 14 & 1.30 & 0.49 & 0.42 & 0.30 & 0.69 & 0.59 \\
\hline 15 & 1.52 & 0.51 & 0.60 & 0.32 & 0.58 & 0.45 \\
\hline 16 & 0.62 & 0.37 & 0.23 & 0.32 & 0.63 & 0.58 \\
\hline
\end{tabular}

\section{Notes:}

a. The estimates of annual energy savings for the Retail Store are for cooling energy savings and do not include potential heating penalties.

b. The School Building is cooled and heated with packaged heat pumps. The estimates of annual energy savings include summertime cooling-energy savings and wintertime heating-energy penalties.

c. The energy savings for the Cold Storage Facilities are for four months from mid-May to midSeptember. The Cold Storage Facilities operate at a lower capacity for the reminder of the year.

\subsection{Discussions and Recommendations}

- For the retail store building, the estimate of annual energy savings in most California climates is over $1 \mathrm{kWh} / \mathrm{ft}^{2}$ of conditioned roof area. Two factors contribute to this high savings: low roof/attic insulation and long hours of air conditioning operation. In comparison, the energy savings in the school building and the cold storage facility are about $0.4-0.5 \mathrm{kWh} / \mathrm{ft}^{2}$. Note that the savings for the cold storage facilities are only for four months 
of mid-May to mid-September. Longer seasonal operation of cold storage will result in higher annual savings.

- The peak demand savings was also very significant in most climate zones--about 0.3-0.5 $\mathrm{W} / \mathrm{ft}^{2}$ for the retail store, $0.2-0.4 \mathrm{~W} / \mathrm{ft}^{2}$ for the school, and $0.5-0.6 \mathrm{~W} / \mathrm{ft}^{2}$ for the cold storage facility. Note that these impressive results have been achieved even with R-30 roof insulation on the cold storage facility.

- In estimating the savings, we used the conditioned roof area (same as conditioned floor area) to normalized the savings. In both the retail store and the cold storage facility, the entire roof was coated with a reflective coating. The coating of the roof over the unconditioned areas would reduce the heat-transfer to the zone and improve comfort, but would not significantly affect air-conditioning energy use. The normalized savings would be lower if we used the total (conditioned and non-conditioned) roof area in the calculations.

- The biggest challenge in this project was to recruit buildings for monitoring. Significant efforts were invested to identify and recruit the three facilities monitored in this study. We also installed monitoring equipment in one building that did not install a cool roof as was originally planed. In future monitoring projects, it is highly recommended to allocate sufficient budget to identify and recruit buildings for monitoring. It would be even more effective if a contract were signed by the building owners (and they are properly rewarded) to participate in the project.

- In a detailed monitoring project where many parameters are specified and measured, it is important to have as many duplicate measurements as possible. This allows compensation for a malfunctioning instrument. In addition, it allows calibration and cross checking of sensors. An additional few thousand dollars spent on sensors would save significant time during the analysis of the collected data.

- Monitoring energy use in occupied buildings is always subject to statistical variation because of the occupancy behavior. In the retail store, we experienced a uniform operation of the HVAC systems during the pre- and post-retrofit period; that made the data analysis fairly straightforward and simple. In the school building, the operation of the building and its HVAC systems was haphazard mainly because of irregular hours of operation during the summer and having the classrooms doors frequently open. This uncontrolled operation of the classrooms made the data analysis task very complicated.

- It is possible that some factors other than those planned have caused changes in the electricity consumption of the building. For example, the first look at the data for the cold storage facility indicated daily energy savings in excess of $2 \mathrm{MWh}$ (over $30 \mathrm{Wh} / \mathrm{ft}^{2}$ per day). A close inspection of the data showed significant chiller electricity savings at night. Further investigation revealed that after the installation of the cool roofs, the operators discovered that the building load can be met with higher evaporator temperatures. As a result, they had increased the suction pressure, resulting in a significant reduction in chillers' energy use that was not directly related to installation of cool roofs.

- We used DOE-2 to simulate and extrapolate the savings for the school and retail store buildings. The current scientific version of DOE-2.1E has significant limitations in 
simulating ammonia chillers and conditioned zones below $55^{\circ} \mathrm{F}$. To extrapolate the savings for the other climate zones, we used empirical correlations, assuming that the savings $(\mathrm{kWh} /$ day or peak $\mathrm{kW})$ are directly correlated to solar intensity. Since the chiller systems at the cold storage facility operate 24 hours a day, use of solar intensity as an indicator of savings produces reliable results.

\subsection{Recommended Future work}

\section{- Extension Of Monitoring Projects To All California Climates.}

The buildings we monitored in this study are only a subset of buildings needed to be monitored, as listed in Table 1. We recommend future monitoring projects to be carried out in accordance with the priorities listed in Table 1. Monitoring projects are needed to demonstrate and showcase the effects of cool roofs in each California climate region.

- Cool Roofs, Optimal Chiller Operation, And Variable Speed Drive For California Cold Storages.

Cool roofs have proven to be extremely effective on the cold storage facilities. Installing cool roofs in the cold storage facilities has resulted in excess capacity by the chillers. The operators have been able to increase the suction pressure of the compressors and hence improve the performance of the chillers significantly. We recommend carrying out a project that investigates in detail the effect of cool (reflective) roofs and by optimal operation of refrigeration systems on reducing cooling loads for cold storages. The optimal operation can include optimal chiller operation as well as installing variable speed drives (VSD) on evaporator and condenser fans.

\section{- Upgrade Of DOE-2 For Simulation Of Cold Storages.}

DOE-2 building simulation program need to be upgraded to simulate ammonia chillers and cold storage facilities.

- The Effects Of Aging And Weathering Of Cool Roofs On Energy And Peak Demand Savings.

We have noticed that some the reflectivity of the roofing materials change with aging and weathering. A study to document the aging and weathering the reflectivity of roofing materials is recommended. We also need to develop accelerated aging protocols for cool roofs. This can be developed in collaboration with Cool Roof Rating Council (CRRC) and ASTM.

\section{- The Longevity Of Cool Roofs.}

Under the AB970, California installed many cool roofs. It is essential to collect data on the performance of those roofs. Many manufacturers of cool roofing materials believe that white roofs last longer, although no specific data have been offered. Roofing materials fail mainly because of four major processes: (1) gradual changes in physical and chemical composition induced by the absorption of ultraviolet (UV) light; (2) aging and weathering (e.g., evaporation of plasticizers in polymers and low-molecular-weight components in asphalt), which are accelerated by high temperatures; (3) diurnal thermal cycling, which stresses the material by expansion 
and contraction; and (4) in the case of many organic roofing materials (e.g., wood), rutting because of moisture. Thermal and UV effects combine: for example, high temperatures greatly accelerate UV-induced photo oxidation. We recommend a study to collect field and laboratory data to evaluate whether cool low-sloped roofs last longer than standard (hot) low-sloped roofs. It is also recommended to review existing preventive maintenance practices that may prolong the life of the roof indefinitely.

\section{- A Database Of Installed Cool Roofs In California.}

The implementation of the Cool Roofs program in California offers several unique opportunities to understand the practical implications of cool roofs on a large scale. We recommend a study to evaluate the large-scale impact of cool roofs, documenting implementation lessons, collecting cost and energy savings data, monitoring performance of the buildings and roofs for several years, and developing a data-base for future applications. In those instances where the roofs of many buildings in a small community is changed (such as a university campus or a large shopping mall), we recommend a study to measure the effects of cool roofs in lowering the ambient air temperature at the community-level. 


\section{REFERENCES}

Akbari, H., M. Pomerantz, and H. Taha. 2001. “Cool Surfaces and Shade Trees to Reduce Energy Use and Improve Air Quality in Urban Areas," Solar Energy 70(3);295-310.

Akbari, H., S. Konopacki, C. Eley, B. Wilcox, M. Van Geem and D. Parker. 1998. “Calculations for Reflective Roofs in Support of Standard 90.1". ASHRAE Transactions 104(1):984-995.

Akbari, H., S. Bretz, D. Kurn and J. Hanford. 1997. "Peak Power and Cooling Energy Savings of High-Albedo Roofs," Energy and Buildings 25:117-126.

Akridge, J. 1998. “High-Albedo Roof Coatings - Impact on Energy Consumption” ASHRAE Technical Data Bulletin 14(2).

ASTM 1997. E-1918: Standard Test Method for Measuring Solar Reflectance of Horizontal and Low-Sloped Surfaces in the Field. Annual Book of ASTM Standards 04.11. Philadelphia, PA: American Society for Testing of Materials.

Boutwell, C. and Y. Salinas. 1986. "Building for the Future-Phase I: An Energy Saving Materials Research Project." Oxford: Mississippi Power Co., Rohm and Haas Co. and the University of Mississippi.

Gartland, L., S. Konopacki and H. Akbari. 1996. "Modeling the Effects of Reflective Roofing". Proceedings, ACEEE 1996 Summer Study on Energy Efficiency in Buildings 4:117-124. Pacific Grove, CA.

Hildebrandt, E., W. Bos and R. Moore. 1998. "Assessing the Impacts of White Roofs on Building Energy Loads" ASHRAE Technical Data Bulletin 14(2).

Konopacki, S. and H. Akbari. 2002 “Energy savings of heat-island-reduction strategies in Chicago and Houston (including updates for Baton Rouge, Sacramento, and Salt Lake City," Lawrence Berkeley National Laboratory Report LBL-49638, Berkeley, CA.

Konopacki, S. and H. Akbari. 2000. “Energy Savings Calculations for Heat Island Reduction Strategies in Baton Rouge, Sacramento and Salt Lake City". Lawrence Berkeley National Laboratory Report LBNL-42890. Berkeley, CA.

Konopacki, S. and H. Akbari. 1998. "Simulated Impact of Roof Surface Solar Absorptance, Attic, and Duct Insulation on Cooling and Heating Energy Use in Single-Family New Residential Buildings". Lawrence Berkeley National Laboratory Report LBNL-41834. Berkeley, CA.

Konopacki, S., H. Akbari, L. Gartland and L. Rainer. 1998. “Demonstration of Energy Savings of Cool Roofs". Lawrence Berkeley National Laboratory Report LBNL-40673. Berkeley, CA.

Konopacki, S., H. Akbari, M. Pomerantz, S. Gabersek and L. Gartland. 1997. “Cooling Energy Savings Potential of Light-Colored Roofs for Residential and Commercial Buildings in 11 U.S. Metropolitan Areas". Lawrence Berkeley National Laboratory Report LBNL-39433. Berkeley, CA. 
Lease, C. 2002. Personal communication. Roofing contractor Craig Lease (Stockton Roofing Company, Stockton, CA) reports that he uses high pressure water (140 gal/1000 $\left.\mathrm{ft}^{2}\right)$ and baking soda $\left(0.5 \mathrm{lb} / 1000 \mathrm{ft}^{2}\right)$ to wash roofs and neutralize acidic pollutants.

Parker, D., J. Huang, S. Konopacki, L. Gartland, J. Sherwin and L. Gu. 1998. “Measured and Simulated Performance of Reflective Roofing Systems in Residential Buildings". ASHRAE Transactions 104(1):963-975.

Parker, D., J. Sonne and J. Sherwin. 1997. “Demonstration of Cooling Savings of Light Colored Roof Surfacing in Florida Commercial Buildings: Retail Strip Mall". Florida Solar Energy Center Report FSEC-CR-964-97. Cocoa, FL.

Rosenfeld, A., H. Akbari, S. Bretz, B. Fishman, D. Kurn, D, Sailor, and H. Taha. 1995. "Mitigation of Urban Heat Islands: Material, Utility Programs, Updates," Energy and Buildings, 22;255-265. 


\section{GLOSSARY}

$\mathrm{A} / \mathrm{C}$ :

Albedo:

ASTM:

Climate Zone:

Cooling energy:

DAS:

Energy Commission:

EER:

Heat flux:

HVAC:

Insolation:

LADWP:

LBNL:

Peak demand:

PIER:

Plenum:

Pre:

Post:

Pyranometer:

Radiant barrier:

Roof underside:

RTD:

RTU:

SDREO:

SEER:

Sky temperature:

SMUD:

STF:
Air conditioning

Solar reflectance

American Society for Testing and Materials

California Thermal Zone (CTZ), as shown in Figure 1

Energy (typically electricity) consumed for cooling by an air conditioner or chiller

Data Acquisition System

California Energy Commission

Energy Efficiency Ratio

Heat flow per unit area across a surface, such as a roof

Heating, Ventilation and Air Conditioning

Solar radiation (0.3 - 2.5 microns); contraction of INcoming SOLar radiATION

Los Angeles Department of Water and Power

Lawrence Berkeley National Laboratory

Daily maximum cooling power demand

Public Interest Energy Research

Space between the bottom of the roof and top of the ceiling

Pre-retrofit (before installation of cool roof)

Post-retrofit (after installation of cool roof)

A device used to measure total solar radiation

A suspended surface with low thermal emittance used to impede radiative heat transfer, such as that through a roof

Bottom of the roof deck

Resistive Temperature Device

Roof top unit (air conditioner)

San Diego Regional Energy Organization

Seasonal Energy Efficiency Ratio

Apparent radiative temperature of the sky, used in calculation of radiation balance of a surface exposed to sky

Sacramento Municipal Utility District

Sacramento Tree Foundation 


\section{APPENDICES}

Appendix A. Building Recruitment Letter

Appendix B. Methodology to Extrapolate Savings from Application of Cool Roofs

Appendix C. Extension of the Cool Roof Retrofit Deadline for 10 Buildings 


\section{APPENDIX A. BUILDING RECRUITMENT LETTER}

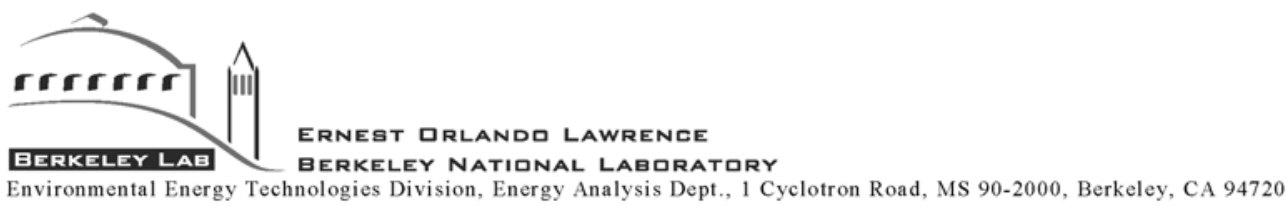

26 March 2002

Dear Program Administrator, Building Inspector, Building Owner, Building Manager, or Roofing Contractor:

The California Energy Commission (CEC) has contracted Lawrence Berkeley National Laboratory (LBNL) to measure the energy savings achieved by buildings participating in the CEC's Cool Roof Rebate program. We are seeking approximately 7 commercial buildings (office, retail, industrial, cold-storage, school, warehouse, and other) in Northern and Southern California that meet the following primary criteria:

- existing roof is dark

- to be retrofit with a cool roof around July 2002

- $\quad$ single story

- roof area 9,000-200,000 $\mathrm{ft}^{2}$

- roof insulation $\leq \mathrm{R}-19$

- no roof insulation to be added

- $\quad \mathrm{A} / \mathrm{C}$ used year-round, or at least June-September

We will monitor weather, building and roof temperatures, and energy use for about two months before and two months after the retrofit. Details are presented on the attached sheet, "Building Owner's Guide To Cool Roof Retrofit Energy Monitoring."

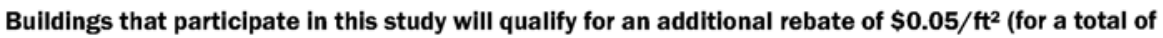
$\mathbf{\$ 0 . 2 0} / \mathrm{ft}^{2}$ ). Buildings owners and roofing contractors will also gain quantitative information about their coolroof energy savings. There are no costs to owner or contractor for participating.

We would like to hear from interested owners and/or contractors as soon as possible, as we intend to begin pre-retrofit monitoring in April. Program administrators and building inspectors are encouraged to alert us as soon as possible to potential candidates.

Thank you very much for your assistance.

Yours truly,

Ronnen Levinson, Ph.D.

Lawrence Berkeley National Laboratory

tel. 510/486-7494

fax. 425/955-1992

e-mail RMLevinson@LBL.gov 


\section{Appendix A. (Continued)}

\section{Building Owner's Guide To Cool Roof Retrofit Energy Monitoring}

Q: What is the objective of this program?

A: Scientists from Lawrence Berkeley National Laboratory (LBNL) and the Davis Energy Group (DEG) will monitor the energy savings achieved by selected buildings participating in the California Energy Commission (CEC) Cool Roof Retrofit Grant Program. The energy savings will be reported to the CEC as part of the program.

Q: How are buildings selected for monitoring?

A: Climate, roof area and insulation, use of air conditioning, and other factors are considered to choose buildings that are both practical to monitor and likely to show measurable energy savings.

Q: How long will monitoring last?

A: Approximately four to six months, ideally April to September. The retrofit would take place midway through the monitoring period.

Q: How will roof-retrofit energy savings be measured?

A: Weather, building and roof temperatures, and energy use will be monitored for approximately two months before and two months after the scheduled cool roof retrofit. Utility bills will also be studied.

Q: What will I learn about the monitored building? Are there other benefits?

A: The owner will receive a copy of the report to the CEC, which will analyze each building's energy use before and after the roof retrofit. For privacy, only owners and researchers will know the identity of the buildings anonymously labeled in the report. Buildings studied in this program will also be eligible for a rebate rate of $\$ 0.20 / \mathrm{ft}^{2}$ (rather than $\$ 0.15 / \mathrm{ft}^{2}$ ).

Q: What access to my building will be needed?

A: Initially, a two-person team will spend one day installing monitoring equipment inside the building (e.g., power meters, data recorders, indoor temperature sensors), on the roof (e.g., weather tower, roof-surface temperature sensors), and in the plenum space below the roof (e.g., surface and air temperature sensors). A 2

$\times 2$ ' wall area in a closet or mechanical room for the monitoring equipment will be needed. During installation, access will be required to the roof, electrical panels, telephone closet, and plenum or attic area. Data will be transmitted daily over a dedicated telephone line. If necessary, a new phone line for this purpose will be installed at no cost.

If the roof is to be coated, roof sensors may be left in place during the retrofit. If the roof is to be replaced, roof mounted-equipment will be removed and reinstalled before and after the retrofit. All equipment will be removed at the end of the post-retrofit monitoring.

Occasional daytime access with 24-hour advance notice may be needed to check the equipment.

Q: What building information will be needed?

A: Utility bills and as-built drawings (building plan, elevations, roof plan, and single-line electrical sheets if possible). We will collect the necessary information when we visit your site.

Q: What about liability for building damage?

A: All installation and monitoring work will be performed by LBNL and DEG personnel with full workman's compensation and professional liability insurance.

Q: Whom can I contact for more information?

A: Contact Ronnen Levinson (tel. 510/486-7494; fax. 425/955-1992; e-mail RMLevinson@LBL.gov) at Lawrence Berkeley National Laboratory. 


\section{APPENDIX B. METHODOLOGY TO EXTRAPOLATE SAVINGS FROM APPLICATION OF COOL ROOFS}

The following is an excerpt from the project describing the Task related to extrapolation of savings.

Task 8 - Extrapolate Savings

\section{Task 8.1 - Analysis Plan for Extrapolation of Savings}

The Contractor shall:

Document the methodology that will be used to model the building parameters (and their interaction with solar radiation) that are important to accurately evaluate the thermodynamics of cool roof systems.

Provide a summary of the existing state of the DOE2 function that will be updated in this contract.

Document the planned improvements that will be made, including how the empirical information collected during the building monitoring will be used in the derivation of scaling factors.

Document how the calculated scaling factors will be used to estimate peak demand and energy use savings for the other buildings participating in the AB970 Cool Communities program that are not monitored as part of this contract.

Provide the documentation described above to the Commission Contract Manager for approval, prior to beginning of Task 8.2.

Deliverable: Refer to bullets, above.

\section{Task 8.2 - DOE-2 Simulations to Extrapolate Savings}

The Contractor shall model the monitored buildings with the DOE-2 building energy simulation program, as documented in Task 8.1. The intent of this task is not to develop a detailed function to model the complete heat transfer process through the roof, but to perform a quick comparison between the simulated energy use and the measured data obtained in Task 7. The intent of this task is to develop scaling factors through comparison of measured and simulated data.

The Contractor shall use the calculated scaling factors to estimate savings of all other buildings (of the type that the model is now calibrated to) involved in the AB970 Cool Communities program in order to improve estimates of energy impacts. The Commission Contract Manager will provide The Contractor with the (completed) building information (submitted by Regional Contractors on a monthly basis), beginning in late March or early April 2001.

Deliverable: Monthly progress reports shall be used to report progress on this task, including any problems or special circumstances that arise during the course of this task. 
LBNL has previously documented cool-roof savings at five buildings in N. CA - two medical offices in Gilroy and Davis, two schools in Sacramento, and a retail store in San Jose - while other researchers have measured cool-roof savings in three other N. CA buildings: an office, a museum, and a hospice in Sacramento. The current study adds five buildings - an office in Irvine, a school near San Diego, and a cold-storage facility and two industrial buildings near Fresno. We continue to seek a retail store, preferably in S. CA or in the Central Valley. The combination of old and new buildings would provide a good geographic and functional distribution of monitored buildings: offices in N. and S. CA, retail stores in N. and S. CA, cold schools in N. and S. CA, storage and industrial buildings in the Central Valley, and a few assorted buildings (museum, hospice) in N. CA.

Clearly, the number of buildings selected for monitoring is not sufficient to perform a statistical analysis of saving potentials from the application of cool roofs. Here is the highlight of our data analysis plan.

1. In Task 7, we will perform a statistical analysis of hourly and daily data. The pre- and post-retrofit daily (and hourly for a given hour) electricity use will be modeled using a simple linear regression of electricity use vs. outside ambient drybulb temperature. We will also investigate the effect of changes in solar radiation on the regression results. We will normalize the cooling electricity use for the pre-retrofit conditions to that of the post-retrofit conditions to estimate savings for the period of monitoring. We will extrapolate savings to the entire cooling season, using the outside temperature (and if the cooling season is long, the insolation) as a predictor.

For buildings that do not show a strong correlation of cooling electricity use to outside temperature (e.g., either buildings with undersized cooling systems or buildings with very high internal loads), we will examine the reduction in the heat conducted into the monitored building as measured by heat flux sensors installed on the roofs. The reduction in conducted heat will be translated into electricity savings, using the manufacturers' supplied air-conditioning performance curves.

2. The buildings will be modeled with DOE-2.1E. We will use the California Thermal Zone (CTZ) weather data to estimate potential savings. Using the correlations developed in Task 7, we will also use the temperature (and possibly insolation) data from the CTZ files to estimate the savings.

3. The ratio of the savings predicted by the correlations (developed in Task 7) to that estimated by DOE- 2 will be the scaling factors for each building type used in the monitoring project.

The approximate maximum level of effort to model the buildings with DOE-2 and compare the savings to those of the correlations is about 6 days per monitored building. Obviously, this limited effort does not allow detailed analyses of hourly data using the actual weather data, comparison of hourly measured and simulated data, and modification of DOE-2 algorithms to improve modeling the heat transfer through the roof.

Hashem Akbari: (510) 486-4287 


\section{APPENDIX C. EXTENSION OF THE COOL ROOF RETROFIT DEADLINE FOR 10 BUILDINGS}
AUG $21200123: 21$
CA ENERGY COMMISSION
$916 \quad 6518886$
p.2

STATE OF CALIFORNA-THE RESOURCES AGENCY

CALIFORNIA ENERGY COMMISSION

1516 NINTH STREET

SACRAMENTO, CA 95814-5512

Date: $\quad$ August 21, 2001

To: $\quad$ Cool Roof Savings Program

Regional Managers

From: Energy Efficiency Committee

California Energy Commission

Subject: Extension of the Cool Roof Retrofit Deadline for 10 Buildings

There is a Public Interest Energy Research (PIER) program currently underway to monitor the energy use impacts of cool roofs on commercial buildings in California. This research has been planned to specifically integrate with the Cool Roof Savings Program you are managing for the California Energy Commission. As part of this research, 10 buildings will be recruited for monitoring pre and post application of cool roofs. These 10 buildings are to be offered the $\$ .20 / \mathrm{sq}$.ft. Cool Roof Savings rebate to encourage their participation in this important research effort, through the summer of 2002.

This memorandum formalizes our approval of the rebate extension to the 10 buildings that participate in this monitoring project. Please implement this extension in your program offering, effective immediately. The extension of this rebate expires on December 31,2002 , or when 10 buildings have been monitored, which ever occurs first.

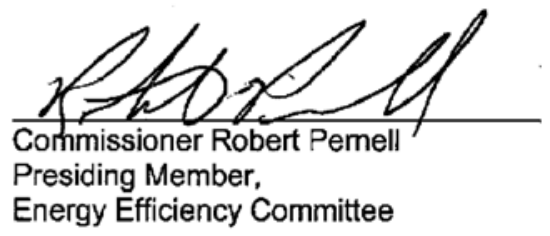

Energy Efficiency Committee

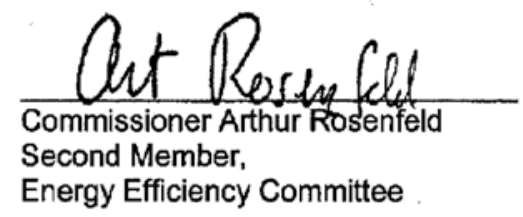

Energy Efficiency Committee 